\title{
DEPOSITIONAL HISTORY OF PALEOCENE SEDIMENTS IN THE OFFSHORE CANTERBURY BASIN, NEW ZEALAND
}

Sanjay Paul Samuel

A thesis submitted for the partial fulfilment of the degree of Masters of Science in Petroleum Geoscience

School of Geography, Environment and Earth Sciences

Victoria University of Wellington 


\section{Abstract}

The Paleocene interval within the Canterbury Basin has been relatively understudied with respect to the Neogene and Cretaceous intervals. Within the Paleocene interval is the Tartan Formation and the Charteris Bay Sandstone, which are potential source and reservoir rocks respectively. These two formations have not been previously mapped in the offshore Canterbury Basin and their limits have not been defined. This study utilises a database of nearly $12,000 \mathrm{~km}$ of $2 \mathrm{D}$ seismic data together with data from four open-file wells and sidewall core samples from three wells and newly availiable biostratigraphic information to better constrain the chronostratigraphical interpretation of seismic data. Seismic mapping together with corroboration from well correlation and core lithofacies analysis revealed new insights into the development of the offshore Canterbury Basin through the Paleocene. These include the delineation of the lateral extents and thicknesses of the Tartan Formation and Charteris Bay Sandstone and location of the palaeo shelfslope break and also the development of a new well correlation panel that incorporates the Tartan Formation for the first time.

This study presents four new paleogeographic maps for the offshore Canterbury Basin that significantly improves our understanding of the development of the basin during the Paleocene. These maps show that during the Earliest Paleocene, the mudstones of the Katiki Formation were being deposited in the south of the study area, with the siltier sediments of the Conway Formation being deposited in the north. The coarser grained Charteris Bay Sandstone was deposited from Early to possibly Middle Paleocene in the northeast. The mudstones of the Moeraki Formation were being deposited in the south at this time. From Middle to Late Paleocene, the mudstones of the Moeraki Formation were deposited in the south and these mudstones onlapped against the Charteris Bay Sandstone which remained as a high in the north. The Tartan Formation was deposited during the Late Paleocene in the central and southern areas of the offshore Canterbury Basin, during a relative fall in sea-level. Deposition had ceased in the north of the study area or erosion possibly removed Late Paleocene sediments from there. During the Latest Paleocene, the mudstones of the Moeraki Formation were deposited over the Tartan Formation in the central and southern parts of the offshore Canterbury Basin with the northern area undergoing erosion, sediment bypass or both. 


\section{Acknowledgements}

I would like to thank my supervisors, Cliff Atkins and Malcolm Arnot for their supervision and encouragement during the course of this study, and to help direct the course of this research. Their advice, discussion, and reviews have contributed greatly to improving this project and my own scientific abilities.

I would like to thank Origin Energy and its affiliates for access to some of their reprocessed seismic lines within the study area. Their seismic lines were of better quality and markedly improved the quality of interpretation possible in this area. I would like to thank the Marine Seismic Data Centre at the University of Texas at Austin for access to their 2D seismic data over the offshore Canterbury Basin.

I would like to thank many people from GNS for their time; Miko Fohrmann for his invaluable advice and discussion on the seismic dataset and its interpretation, Lucia Roncaglia for her help and discussion with the well correlation, Ian Raine for advice on biostratigraphy at the offshore wells, and Poul Schioler for comments and advice on the deposition of the Tartan Formation in the Great South Basin and Canterbury Basin

And finally, I wish to thank my family for their encouragement and support, without which I could not have completed this study and Chris for her editing help and many discussions. 


\section{Table of Contents}

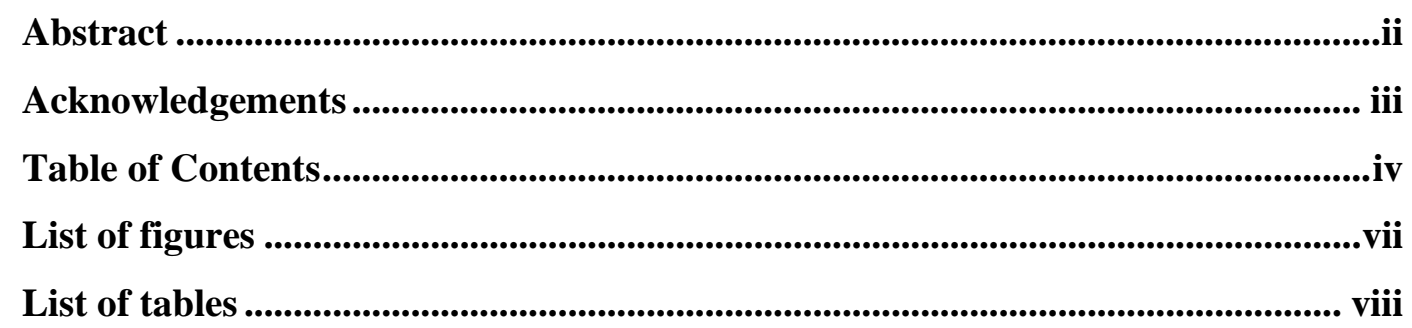

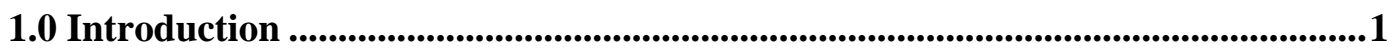

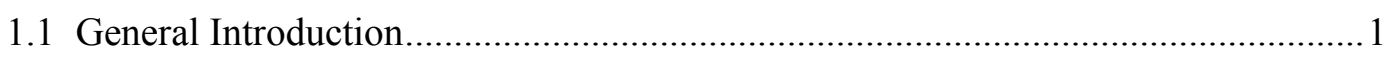

1.2 Previous knowledge of the Paleocene and Eocene interval in the offshore Canterbury

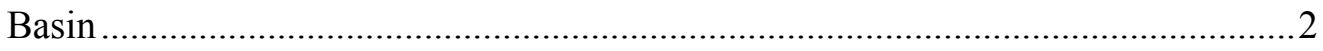

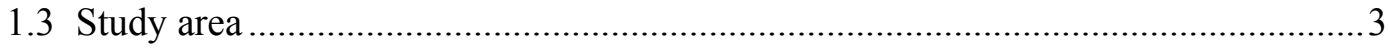

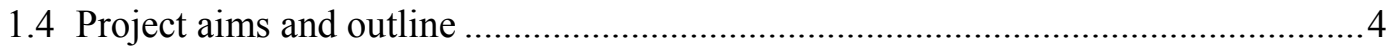

2.0 Geological Setting of Canterbury Basin ..................................................................6

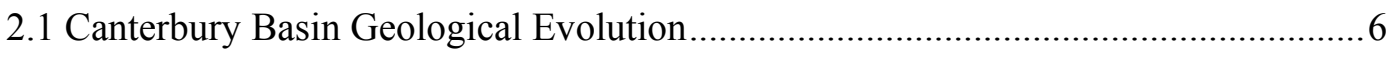

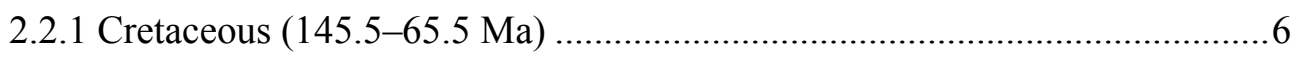

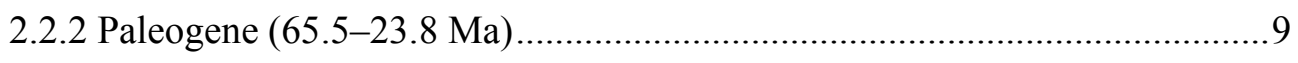

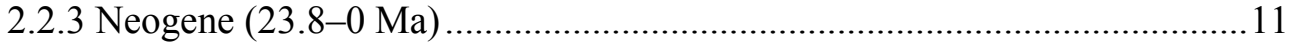

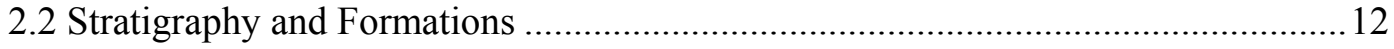

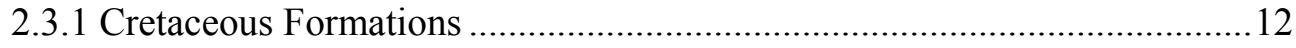

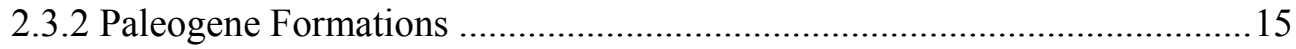

2.3 Previous Knowledge of Paleogene Interval (Seismic Reflectors)...........................25

3.0 Regional Seismic Interpretation...................................................................28

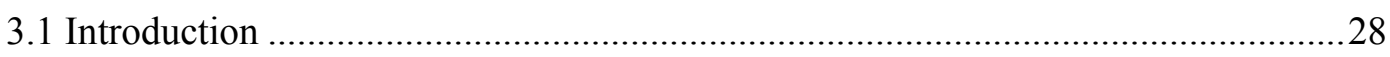

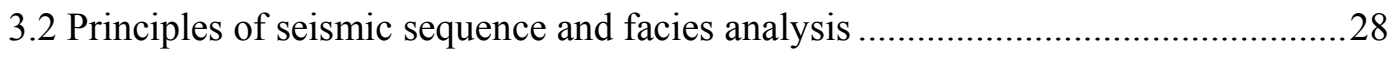

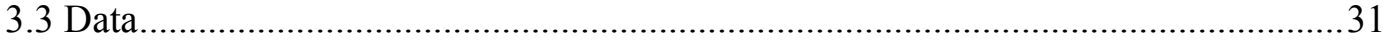

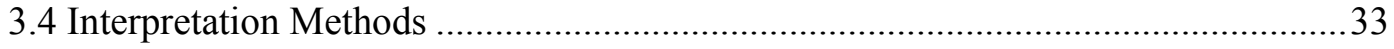

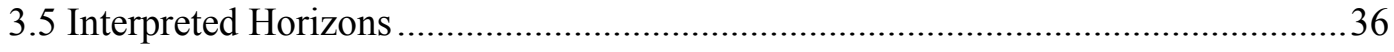

3.6 Seismic Facies of Paleocene-Eocene sediments .................................................. 45

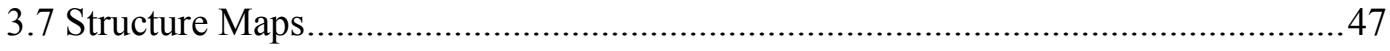

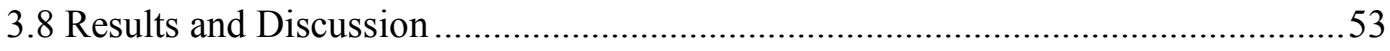




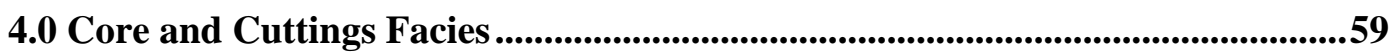

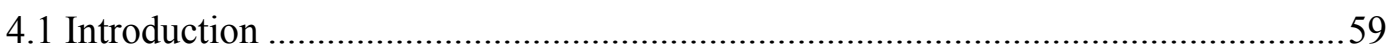

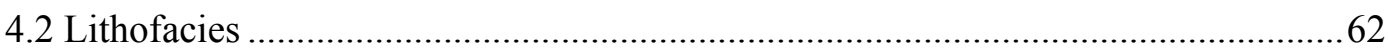

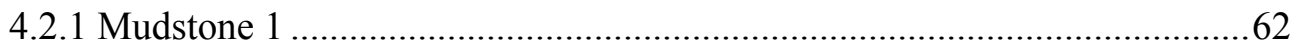

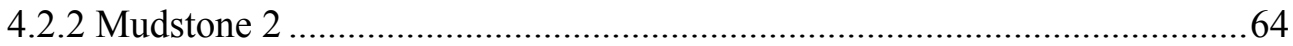

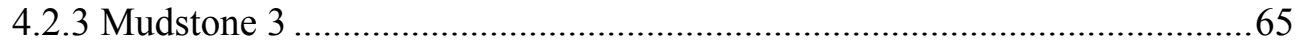

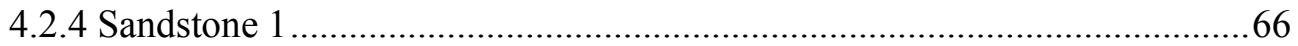

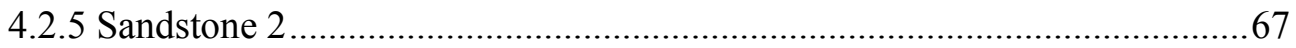

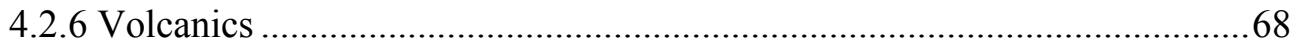

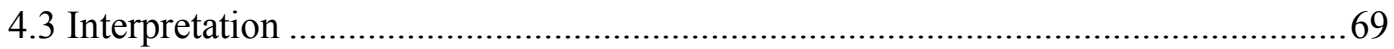

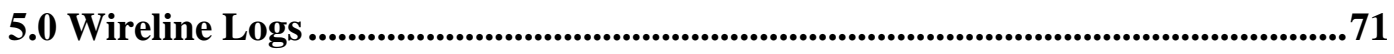

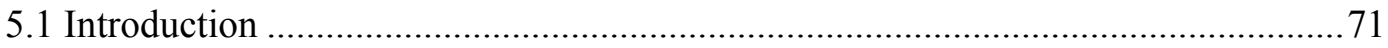

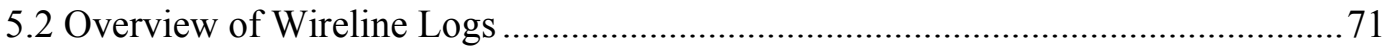

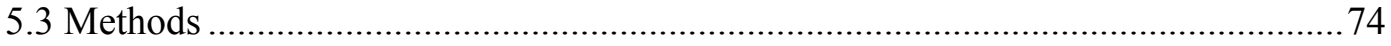

5.4 Formation Tops and Chronostratigraphic surfaces.............................................. 75

5.4.1 Top Hampden Formation …................................................................. 76

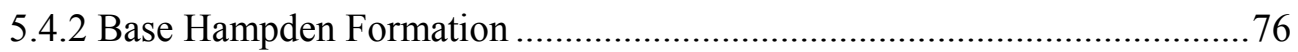

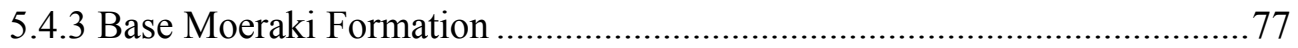

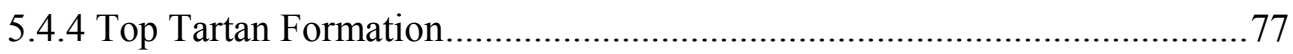

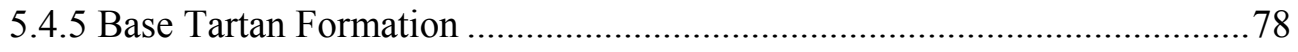

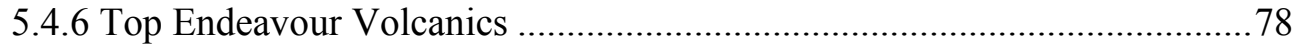

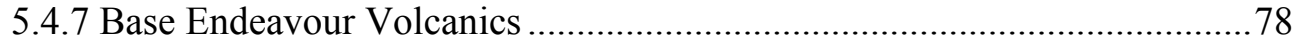

5.4.8 Top Moeraki Formation (lower) ............................................................. 79

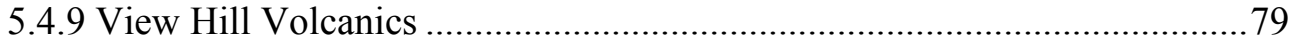

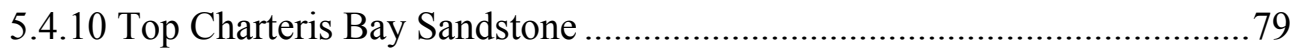

5.4.11 Base Charteris Bay Sandstone ................................................................ 79

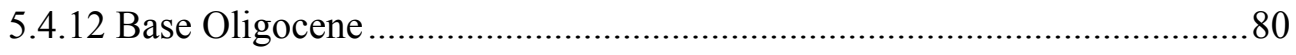

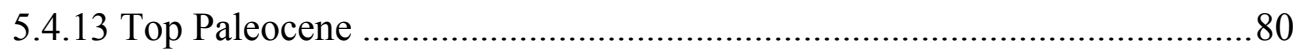

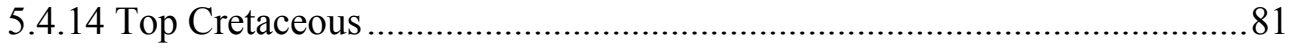

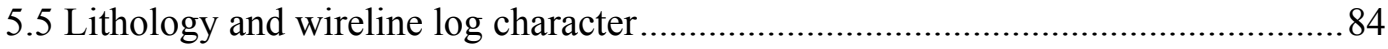

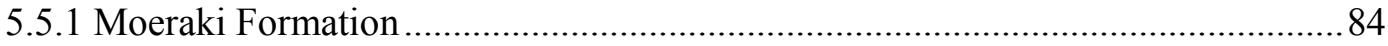




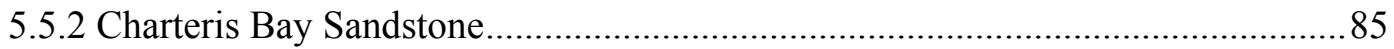

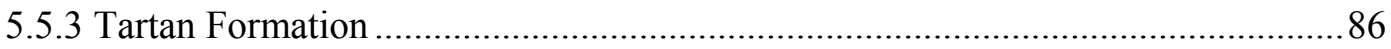

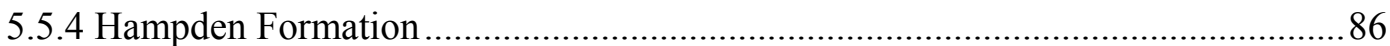

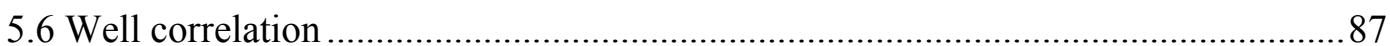

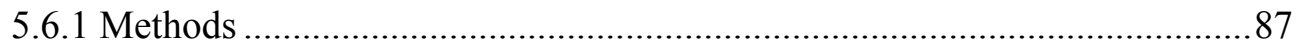

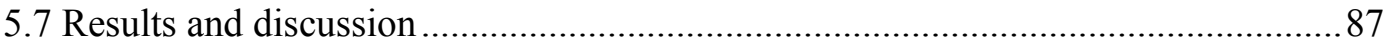

6.0 Paleogeography and Synthesis .......................................................................................91

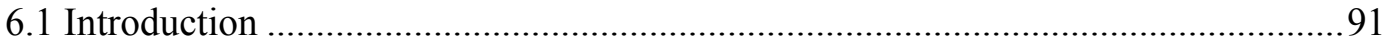

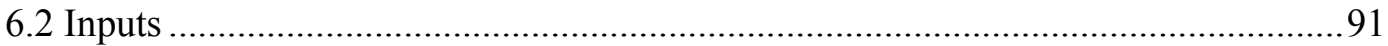

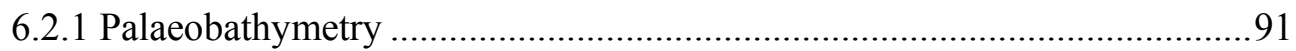

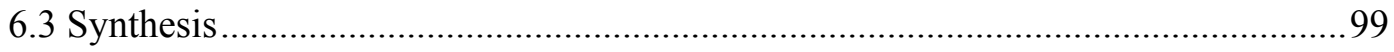

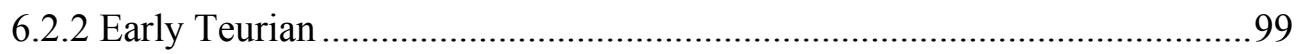

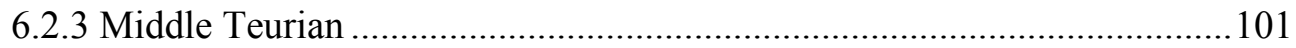

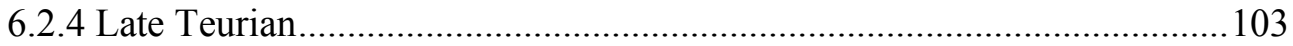

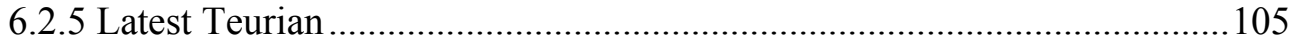

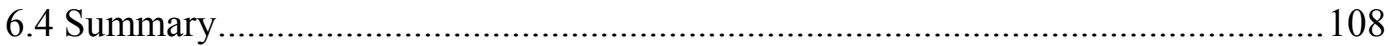

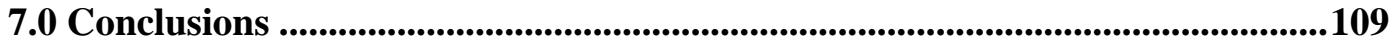

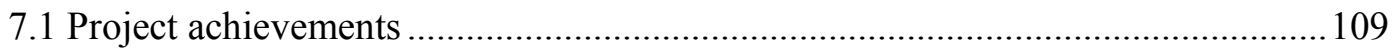

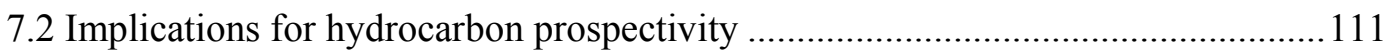

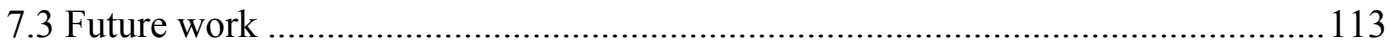

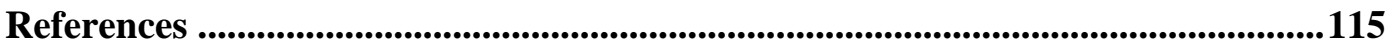

Appendix A. New Zealand Paleogene Timescale..................................................124

Appendix B. Biostratigraphy of the Paleocene and Eocene interval in the offshore Canterbury Basin wells .........................................................................125

Appendix C. Related petroleum, seismic and biostratigraphy reports ..............134

Appendix D. Seismic lines..........................................................................137

Appendix E. Well Data ................................................................................................ 140

Appendix F. Sidewall Core Descriptions and Photographs ..................................141

Appendix G. Well Sheets....................................................................................................... 155 


\section{List of figures}

Figure 1.1: Map of the offshore Canterbury Basin...................................................

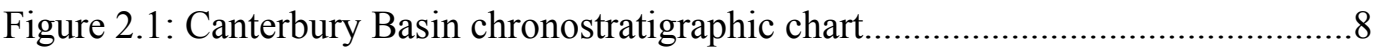

Figure 2.2: Cretaceous to Paleocene paleogeographic maps of Canterbury Basin..........9

Figure 2.3: Paleocene to Oligocene paleogeographic maps of Canterbury Basin..........11

Figure 2.4: Locations of deposition of Waipawa Formation and equivalents................22

Figure 2.5: Planktonic Foram Biochronozones...........................................................2.

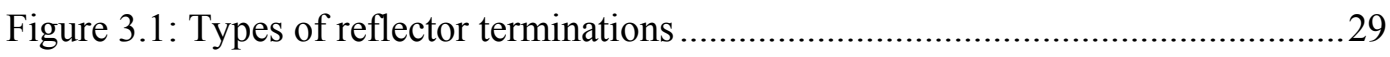

Figure 3.2: Configuration of typical reflection patterns ............................................. 30

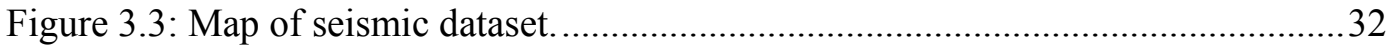

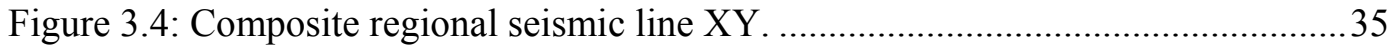

Figure 3.5: Seismic line CB82-17 showing base Oligocene reflector ...........................38

Figure 3.6: Seismic line B210B showing base Oligocene amplitude change. ................ 38

Figure 3.7: Seismic line ANZ-001 showing the top Paleocene reflector.. ....................39

Figure 3.8: Seismic line CB82-17 showing the well pick for top Cretaceous...............40

Figure 3.9: Seismic line CB82-52b showing top and base Tartan Formation...............41

Figure 3.10: Seismic line CB82-20 showing amplitude changes of base Oligocene. ... 42

Figure 3.11: Seismic line ANZ-001 showing the Charteris Bay Sandstone ................43

Figure 3.12: Seismic line CB82-25 showing Charteris Bay Sandstone downlap..........44

Figure 3.13: Seismic line CB82-19 showing Charteris Bay Sandstone downlap..........45

Figure 3.14: Seismic line CB82-11 showing Charteris Bay Sandstone downlap..........45

Figure 3.15: Seismic line CB82-30 showing showing onlap....................................47

Figure 3.16: Two-way travel-time (TWTT) map of the top Cretaceous......................48

Figure 3.17: Two-way travel-time (TWTT) of the top Paleocene ...............................49

Figure 3.18: Two-way travel-time (TWTT) of the base Oligocene ............................49

Figure 3.19: Two-way travel-time (TWTT) of the top Tartan Formation. ...................50

Figure 3.20: Two-way travel-time (TWTT) of the base Tartan Formation .................50

Figure 3.21: Two-way travel-time (TWTT) of the top Charteris Bay Sandstone.........51

Figure 3.22: Two--way travel-time (TWTT) the base Charteris Bay Sandstone...........51

Figure 3.23: TWTT isopach map of the Charteris Bay Sandstone................................52

Figure 3.24: TWTT isopach map of the Tartan Formation.........................................52 
Figure 3.25: Seismic line CB82-11 showing large normal fault................................55

Figure 3.26: Seismic line CB82-25 showing small normal faults near Resolution-1....55

Figure 3.27: Seismic line CB82-19 showing small faults very close to Resolution-1..56

Figure 3.28: Erosional truncation below base Oligocene on seismic line CB82-47b....56

Figure 3.29: Erosional truncation below base Oligocene on seismic line CB82-25......57

Figure 3.30: Erosional truncation below base Oligocene on seismic line CB82-36......57

Figure 4.1: Representative sidewall core sample of Mudstone 1 facies........................63

Figure 4.2: Mudstone 1 sidewall core sample at Endeavour-1 .....................................64

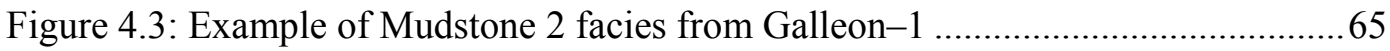

Figure 4.4: Example of Mudstone 3 facies from Galleon-1 .........................................66

Figure 4.5: Example of Sandstone 1 Facies from Resolution-1 .................................67

Figure 4.6: Example of Sandstone 1 Facies from Endeavour-1...................................6

Figure 4.7: Example of the Volcanics Facies from Endeavour-1 .................................69

Figure 5.1: Gamma ray log motifs of the top Moeraki and Tartan Formations.............8 84

Figure 5.2: Gamma ray log motif of the Charteris Bay Sandstone at Resolution-1 ......85

Figure 5.3: Gamma ray log characteristics of the Hampden Formation ........................86

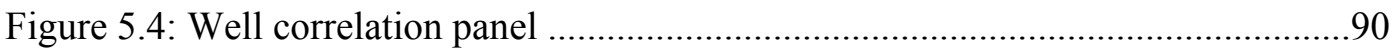

Figure 6.1: Marine paleoenvironmental classification scheme .................................. 92

Figure 6.2: Legend for the paleogeographic maps .................................................. 99

Figure 6.3: Early Teurian paleogeographic interpretation of the study area................101

Figure 6.4: Middle Teurian paleogeographic interpretation of the study area.............103

Figure 6.5: Late Teurian paleogeographic interpretation of the study area................... 105

Figure 6.6: Latest Teurian paleogeographic interpretation of the study area............... 107

\section{List of tables}

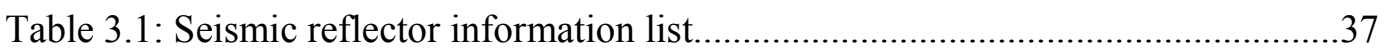

Table 4.1: List of sidewall core samples...................................................................61

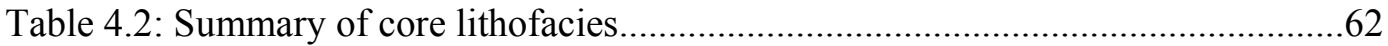




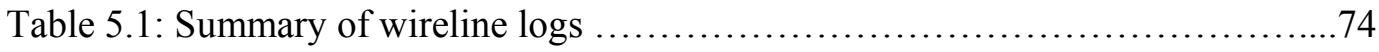

Table 5.2: List of original and revised Stage boundaries and formation tops................83

Table 6.1: Palaeobathymetric summary for Galleon-1 and Endeavour-1...............97

Table 6.2: Palaeobathymetric summary for Clipper-1 and Resolution-1...............98 


\subsection{Introduction}

\subsection{General Introduction}

The Canterbury Basin lies along the east coast of New Zealand's South Island (Figure 1.1). It is a basin covering about $55,000 \mathrm{~km}^{2}$ and extends from the Canterbury Plains on land to an offshore region east of South Island into the deeper waters of the Bounty Trough. There is more than $5 \mathrm{~km}$ of Cretaceous to Cenozoic sediment and southwards, the Canterbury Basin is contiguous with the larger Great South Basin (Sutherland and Browne, 2003). The Canterbury Basin is currently an active area for oil and gas exploration with numerous companies working in the area.

The depositional history of the Canterbury Basin is known broadly, with the basin, like much of the New Zealand continent undergoing a transgression from the Late Cretaceous to the Oligocene and a regression from the Miocene onwards. The Paleogene sequence is understudied in contrast to the Neogene and Cretaceous successions and although it is a prospective basin, there has been limited exploration so far with only nine wells drilled, out of which five were offshore.

Although the Canterbury Basin has not yet had hydrocarbon producing wells, it has been shown to contain working petroleum systems. Confirmed gas-condensate shows were recorded in two offshore wells, Clipper-1 and Galleon-1. In Clipper-1 the shows were in Mid-Cretaceous sandstone interbeds and a condensate sample was recovered from a repeat formation test (Hawkes \& Mound 1984). In Galleon-1, gas-condensate was present in a massive Late Cretaceous sandstone unit and flowed up to $2240 \mathrm{bbl} /$ day of condensate and up to $30 \times 10^{6} \mathrm{~m}^{3} /$ day of gas (Wilson 1985). Further condensate shows were present in sandstones at greater depth (Wilson, 1985). Both these intervals were within the Late Cretaceous sediments. Some unconfirmed reports of hydrocarbon seeps have also been noted in onshore Canterbury (Field \& Browne, 1989a). The Cutter-1 well, for which information is not yet open-file had gas shows in tight Eocene sands.

The Paleocene interval within the Canterbury Basin contains potential source and reservoir rock units in the Tartan Formation and Charteris Bay Sandstone respectively. The Tartan 
Formation is widely thought to be an equivalent of the Waipawa Black Shale of the East Coast Basin which has expelled oil, and hence is of interest to the oil and gas industry. The Charteris Bay Sandstone was the main reservoir target during the drilling of the offshore Resolution-1 well. It had excellent porosities but was hydrodynamically flushed. Both these units have not been mapped in the public domain. Revised lithological and biostratigraphic information from previous workers has made it possible in this study, to tie seismic lines to wells with higher accuracy, and subsequently, to map and investigate the thickness and extents of these units over the offshore Canterbury Basin.

This thesis investigates the regional depositional system and paleogeography of the Paleocene interval within the offshore extent of the Canterbury Basin utilising seismic interpretation, wireline logs and core information.

\subsection{Previous knowledge of the Paleocene and Eocene interval in the offshore Canterbury Basin}

Most previous work in the Canterbury Basin has focused on the Cretaceous succession as it hosts the main reservoir and source rock intervals. Much of the seismic interpretation in the area has been done by BP Shell Todd as part of their exploration strategy for oil and gas. Of the data in the public domain, nine reflectors of varying lateral extents have been mapped (Mound, 1984). Of these mapped horizons, the reflectors in the Paleogene include the base of the Paleocene, Late Paleocene Horizon and the Oligocene Horizon. Detailed, local seismic mapping of a part of the Paleogene succession has been done by Mogg (2008).

Previously, paleogeographic maps for the Paleogene interval in the Canterbury Basin have been made at the Cretaceous-Tertiary boundary (Early Teurian), Paleocene-Eocene boundary (Waipawan), Middle Eocene (Early Bortonian), Late Eocene (Early Runangan) and the Eocene-Oligocene boundary (Early Whaingaroan) by Field and Browne (1989a).

Open-file seismic data (held by the Ministry of Economic Development), and data from newer seismic surveys (Seismic Data Centre at University of Texas at Austin) over the offshore region of the basin is now of sufficient extent and density, that combined with 
data from revised biostratigraphy, a detailed seismic interpretation over the Paleocene interval is possible.

\subsection{Study area}

The study area of this research project is restricted to the offshore extent of the Canterbury Basin and encompasses the area of the four open-file wells drilled there (Figure 1.1). Since drilling of these wells, well data has been revised and higher quality seismic data is available to allow a better constrained interpretation of the geological history of this offshore part of the Canterbury Basin. This thesis contributes to the geological understanding of the Canterbury Basin by providing a detailed study of the Paleocene interval over the study area. 


\section{CANTERBURY BASIN}

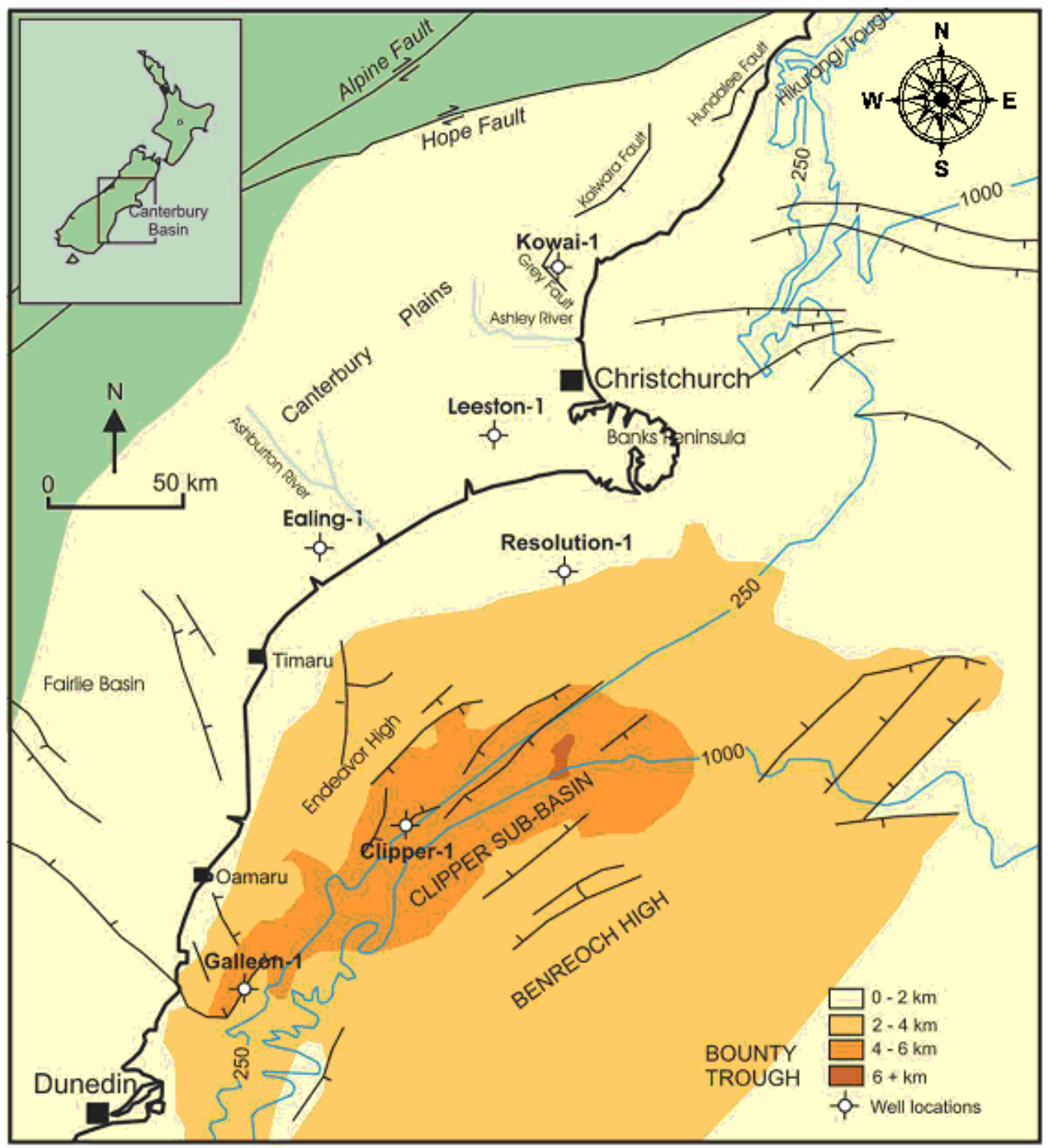

Figure 1.1: Map of the offshore Canterbury Basin between Banks Peninsula in the North and Dunedin towards the south. Location of the open-file wells are shown with information on sediment thicknesses. After Crown Minerals, (2008).

\subsection{Project aims and outline}

The aim of this project is to investigate the spatial and temporal development of the

Paleocene and Eocene sediments within the offshore extent of the Canterbury Basin. In particular, to map the chronostratigraphic reflectors corresponding to the top Cretaceous, top Paleocene and base Oligocene, and to map the spatial and temporal development of the Tartan Formation and the Charteris Bay Sandstone. This was achieved through regional seismic interpretation, wireline log analysis and correlation, and sidewall core analysis. 
Interpretation of several Paleocene and Eocene reflectors (top Cretaceous, top Paleocene, base Oligocene, top and base Tartan Formation, top and base Charteris Bay Sandstone) on four regional composite seismic lines and subsequent in-fill lines, led to the creation of Two-Way Travel-Time (TWTT) structure maps and isopach maps (Chapter 3). Identification, description and mapping of seismic data provided constraints for the development of paleogeographic maps and information on the processes and development of the Paleocene sediments. Core facies were analysed to provide information on the sediments present within the seismically mapped subsurface interval (Chapter 4). These were then integrated with analysis and correlation of wireline logs and biostratigraphic data from key wells (Chapter 5). This information was then combined and presented as revised paleogeographic interpretations for the Paleocene (Chapter 6). 


\subsection{Geological Setting of Canterbury Basin}

\subsection{Canterbury Basin Geological Evolution}

This section presents a summary of the accepted tectonic and sedimentary development of the Canterbury Basin since its inception in the Cretaceous. A more complete review is found in Field and Browne, (1989a). A map of the Canterbury Basin is presented in Figure 1.1 .

\subsubsection{Cretaceous (145.5-65.5 Ma)}

The formation of the Canterbury Basin was initiated during the Cretaceous as part of the break-up of eastern Gondwana (Field and Browne, 1989b). The Australasian margin was a convergent plate boundary prior to the break up of Gondwana with the Phoenix Plate being subducted westward along an extensive trench system (Ballance, 1992). A great thickness of Permian to Late Jurassic sediments accumulated along this system and the subsequent folding, uplift and erosion of this sequence during the Rangitata Orogeny (about 142 to 99 million years ago) created the metasediments of the Torlesse Supergroup which constituted the basement for basin formation (Bennett et al., 2000). These Torlesse sediments essentially consist of a series of interbedded mud rich sandstone turbidites (greywacke) and claystones (argillites) folded and metamorphosed to low-grade zeolite or prehnite/pumpellyite facies (Bennett et al., 2000).

Prior to the break up of Australia and Antarctica, crustal stretching and subsidence led to the formation of numerous half grabens, the remnants of which can be found at Banks Peninsula, Hewson River, Kyeburn and near Shag Point (Field and Browne, 1989a). Progressive unroofing of the Haast schist on the south side of the Waihemo Fault is recorded by the conglomerates at both Kyeburn and Shag Point (Field and Browne, 1989b). Mid-Cretaceous volcanism such as the Mt. Somers volcanics (89+/- 2 My) was widespread although it is now best exposed in mid Canterbury. In the Canterbury Bight, seismic reflection profiles indicate that the main basin, the Clipper Sub-basin, was bounded to the east by a growth fault (Field and Browne, 1989b). The Clipper Formation consisting of up to $2000 \mathrm{~m}$ of Mid-Cretaceous coal measures and paralic sediments was 
laid down over a large part of the Canterbury Bight and are the most widespread potential source and reservoir rocks to have reached thermal maturity in the region (Figure 2.1;

Figure 2.2) (Burwood, 1976). At Clipper-1 and Endeavour-1, the only two wells to have penetrated this formation, the Clipper Formation consists mainly of interbedded units of sandstone and mudstone and appears to fine up-sequence, being pebbly at the base and coaly towards the top (Hawkes and Mound, 1984).

Just east of Timaru lies the smaller Caroline Basin which contains similar deposits, numerous half grabens and is inferred to have had a similar history to the Clipper Subbasin during the Cretaceous. Topographic highs present during this time include the Canterbury Bight High, a NE trending topographic high which dominated the western part of the Canterbury Bight (Haskell et al., 1989b) and the Benreoch and Zapata Highs that existed east and southeast of the Clipper Sub-basin (Field and Browne, 1989b). The Chatham Rise remained sub-aerial until the Late Paleocene (Figure 2.2) (Wood et al., 1989).

Following the start of sea-floor spreading in the Tasman and South Pacific at c.85Ma, the subsequent thermal cooling of the continental lithosphere led to the onset of marine incursion into the rift basins as recorded by the Katiki Formation, (Bennett et al., 2000; BP Shell Todd, 1984). The locally dolomitic, marine, dark mudstone of the Katiki Formation overlies the Clipper Formation at both Clipper-1 and Endeavour-1 (Figure 2.1) (Field and Browne, 1989a). The foraminifera at Clipper-1 suggest that the Katiki Formation was deposited at bathyal depths indicating a rapid relative rise in sea level in the Santonian (Crux, 1984). The Katiki Formation grades into the Conway Formation in the north of the Canterbury Basin. The Conway Formation is a Late Cretaceous sandstone-siltstone facies and is thought to be an equivalent of the Whangai Formation in the east coast of the North Island (Crampton, 1988). The marine transgression during the Cretaceous led to widespread deposition of paralic coal measures in the western (presently onshore) part of the region in the Campanian-Maastrichtian (eg., Taratu, Papakaio and Broken River Formations) (Field and Browne, 1989a). 


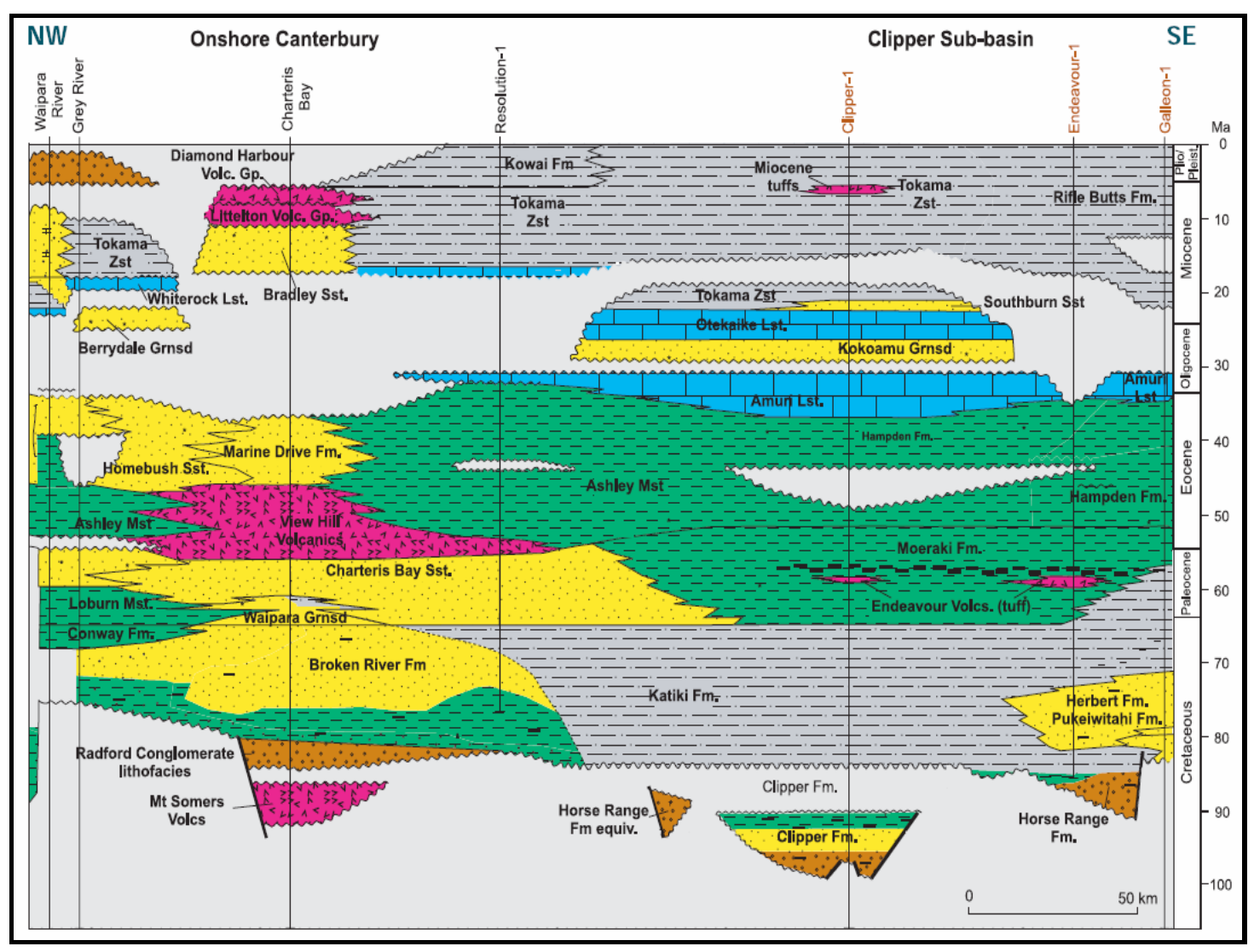

Figure 2.1: Canterbury Basin chronostratigraphic chart showing different rock units and their time of deposition from northwest to southeast. Crown Minerals, (2009). 


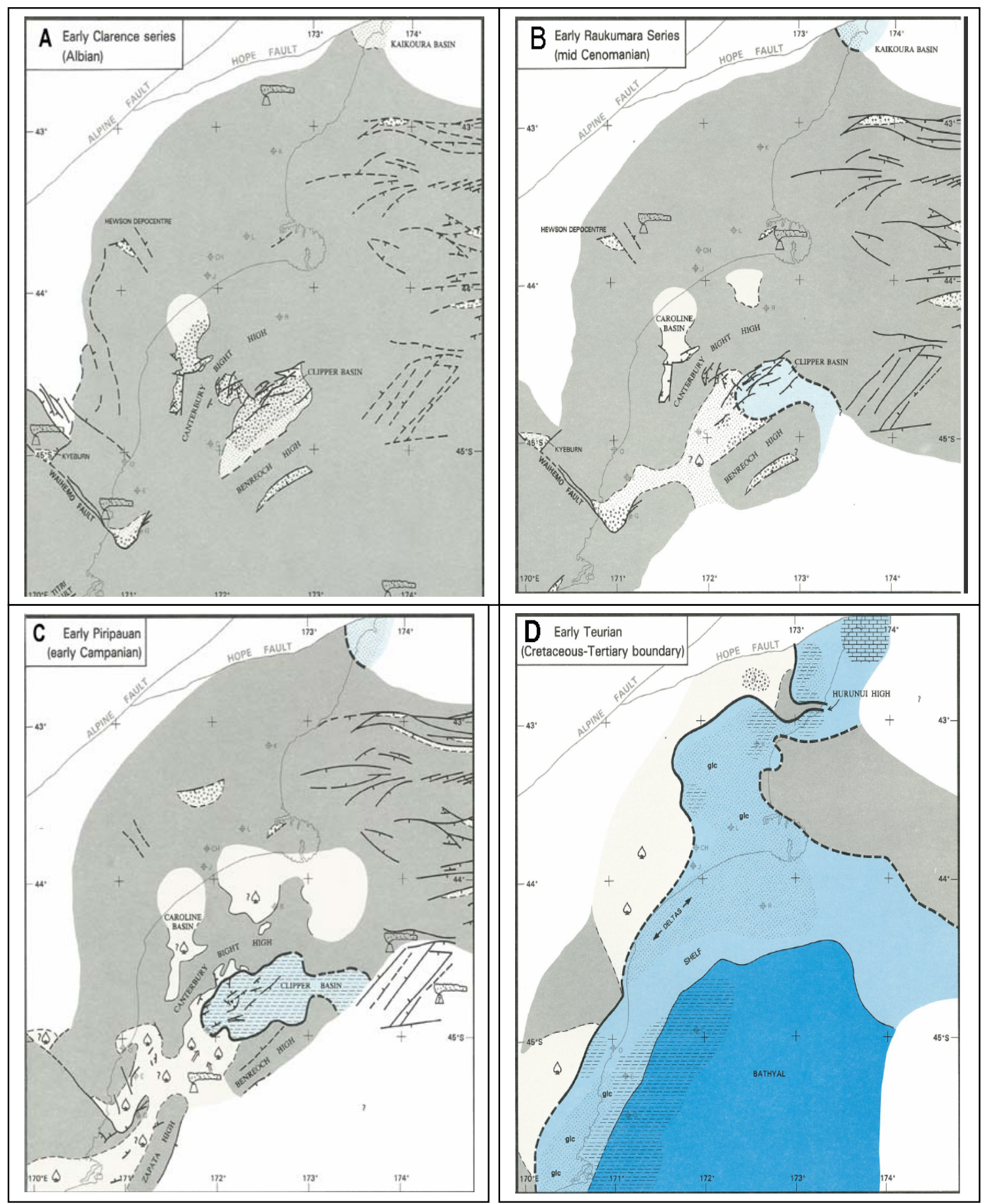

Figure 2.2: Paleogeographic map of the Canterbury Basin from the Mid-Cretaceous to the CretaceousTertiary boundary. After Field and Browne (1989a).

\subsubsection{Paleogene (65.5-23.8 Ma)}

The thermal subsidence characterising the Maastrichtian continued into the Paleocene although at a slower rate. In the Canterbury Bight, medium to dark grey mudstones of the Moeraki Formation were deposited (Section 4.2.2), and the dark mudstones of the Loburn 
Formation with the overlying greensands of the Waipara Greensand were deposited in North Canterbury (Figure 2.1) (Kamp, 1986). Quartzose and slightly glauconitic, fine grained sandstone of the Charteris Bay Sandstone was deposited during the Paleocene in shallow, high energy marine environments in North Canterbury and was encountered offshore within the Resolution-1 well (Figure 2.1; Figure 2.2 DFigure 2.3). The Charteris Bay Sandstone outcrops in Lyttleton Harbour at Charteris Bay. The Endeavour Volcanics were encountered at Endeavour-1 in Paleocene age sediments from 1809m-1942m and a lesser concentration of the volcanics mixed with mudstones was present in Clipper-1 from 3005m-3168m (Section 5.4). The mudstones above the volcanics at Endeavour-1 were seen to be baked by the volcanics which indicates an intrusive origin for the basalt, which possibly solidified at shallow depths (Haskell, 1989a). Within the Paleocene interval in Endeavour-1 brown carbonaceous mudstones occur between 1729m and 1758m (Section 4.2.3), and this is correlated with the Waipawa Black Shale of the Marlborough-East Coast Basin (Haskell, 1989a) and is thought to be an equivalent of the Tartan Formation in the adjacent Great South Basin (Schioler et al., 2009). This formation is inferred to be present at Galleon-1, Clipper-1 and Endeavour-1 and is a potential source rock. The Eocene interval shows a similar depositional history to the Late Paleocene with continuing transgression (Figure 2.3). Calcareous mudstones of the Ashley and Hampden Formations which pass up-sequence into Eocene and Early Oligocene micrites of the Amuri Formation characterise deposition during the Eocene (Figure 2.1) (Field and Browne, 1989a). The Eocene sequence in the west is more varied with the addition of quartzose sands of the Homebush, Karetu and Opawa sandstones. Mild tectonism manifest as faulting and erosion in the northwest started in the Late Eocene (Haskell, 1989a).

Inception of the Alpine Fault plate boundary occurred in the Late Oligocene and was accompanied by extensional or partly transtensional tectonism (Field and Browne, 1989b). This resulted in the formation of a NE-trending ridge along the Canterbury Bight and subsidence continued on either side of it. The Oligocene sequence is regionally quite thin and has been interpreted to reflect a period of lower tectonic activity, submerging of the New Zealand continent and the effect of the Circum-Antarctic current in the area (Carter, 1985) (Figure 2.3). The deposition of the Amuri and Amberley Limestone's and the development of a major regional unconformity characterise the Oligocene sequence (Figure 2.1). 


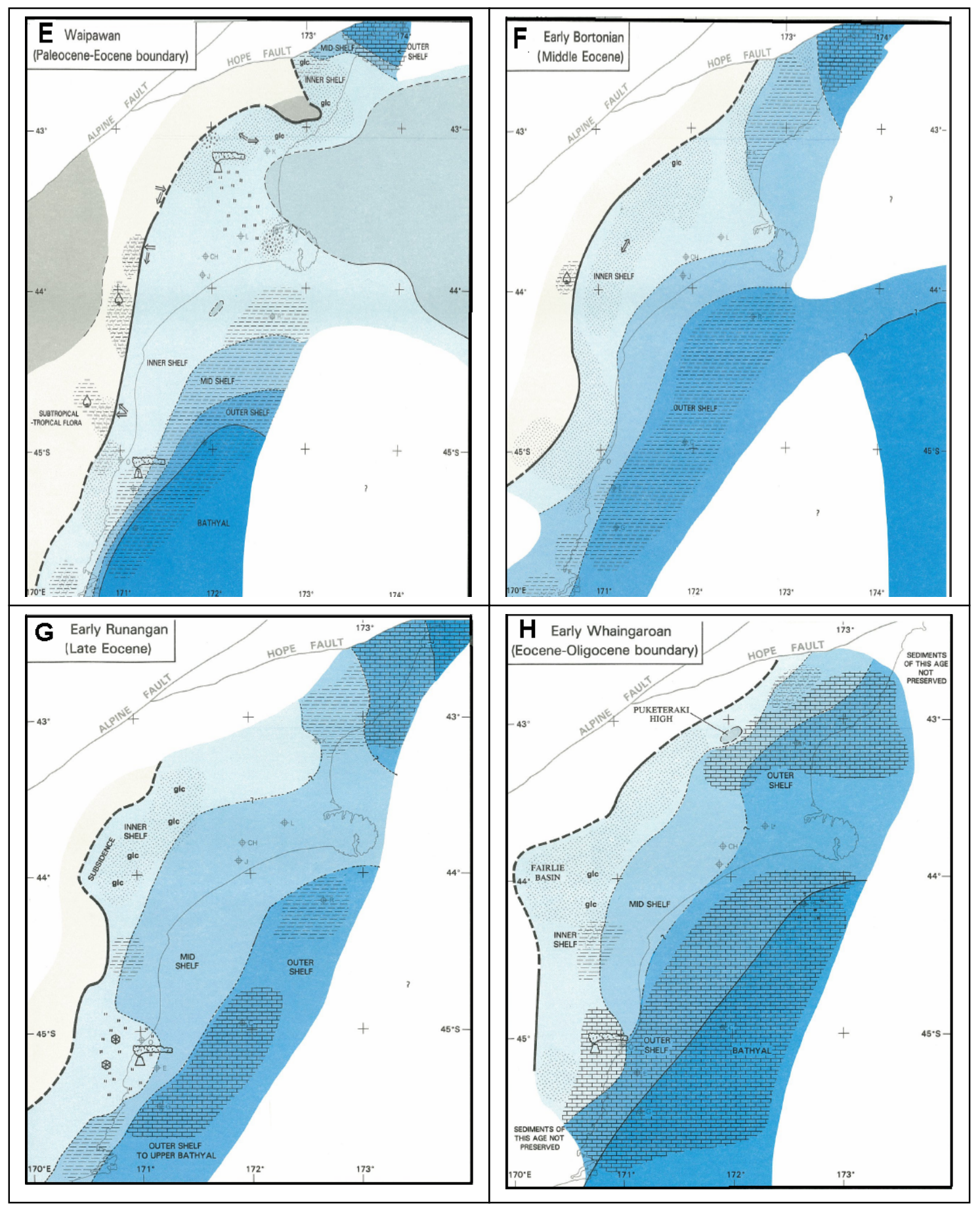

Figure 2.3: Paleogeographic map of the Canterbury Basin from the Paleocene/ Eocene boundary to Eocene/ Oligocene boundary. After Field and Browne (1989a).

\subsubsection{Neogene (23.8-0 Ma)}

Tectonism increased throughout the Neogene in response to the rising of the Southern Alps in the west (Carter, 1988). This led to increased clastic sedimentation from erosion of pre- 
Neogene cover sediments and Permian to Cretaceous basement rocks. These sediments formed an eastward prograding sediment wedge that now forms the continental shelf in Canterbury (Field and Browne, 1989a).

By Pliocene times the Kowai Formation consisting of thick sheets of conglomerates was laid down in the west in a terrain increasingly folded and faulted. Towards the east siltstone deposition continued. The preservation of a virtually undeformed Neogene sequence suggests little or no tectonism during that time (Haskell and Wylie, 1997).

The most intense deformation in the Neogene occurred in North Canterbury and was associated with the Hikurangi Trough section of the plate boundary which was moving southward (Field and Browne 1989a). In the Canterbury Bight however little evidence is seen of Neogene deformation with Cretaceous structures remaining relatively undisturbed. Towards the west some faults such as the Waihemo Fault appeared to have been rejuvenated with reverse movements (Field and Browne, 1989a).

Volcanism was active in the Neogene but is not directly correlatable to any tectonic event (Bennett et al., 2000). The four main centres of volcanism in the Neogene were Otago Peninsula (Middle Miocene), Banks Peninsula (Late Miocene), Timaru- Geraldine (Pliocene) and Ury Knolls (Plio-Pleistocene) (Field and Browne, 1989b).

\subsection{Stratigraphy and Formations}

This section reviews the stratigraphy and formations present within the Canterbury Basin with emphasis on the offshore part of basin. The Canterbury Basin chronostratigraphic chart is presented in Figure 2.1.

\subsubsection{Cretaceous Formations}

\section{A. Clipper Formation}

These are the oldest recognised sediments in the Canterbury Basin (Figure 2.1) and have been assigned to the Mid to Late Cretaceous Clarence and Raukumara Series (Ngaterian (Cn) to Teratan (Rt)) by Hawkes and Mound (1984), and the following description of the 
formation is summarised from their work except where mentioned. The Clipper Formation is subdivided into four members on the basis of changes in lithology and log response. From oldest to youngest these are: Lower Sandstone member, Upper Sandstone member, Interbedded member, and the Coal Measures member.

The Lower Sandstone member consists of massive sandstone interbeds between 5 and $20 \mathrm{~cm}$ thick. Hawkes and Mound (1984) picked the top at a reduction in gamma ray response corresponding to the development of sandstone interbeds within an argillaceous matrix. The sandstones are quartzose to sublithic, poorly sorted, coarse to very coarse grained, and pyretic. The interbedded mudstones are medium grey to dark grey, micromicaceous and carbonaceous (Hawkes and Mound, 1984; Simpson, 1993). The Upper Sandstone member is characterised by an increase in the number of sandstone interbeds and greater variation in the individual sandstone unit's thickness, ranging from $1 \mathrm{~m}-10 \mathrm{~m}$ thick. These sandstones are quartzose, fine to coarse grained, rounded to subangular, non-calcareous, and occasionally carbonaceous. The interbedded member is characterised by the presence of discreet sandstone interbeds within a mudstone dominated sequence. The sandstone beds range in thickness from $1 \mathrm{~m}-5 \mathrm{~m}$. The top of this member was picked at the first down hole occurrence of sandstone within the Clipper Formation. Sandstones within this member are quartzose, very fine grained, micaceous and carbonaceous with an argillaceous matrix. Interbedded mudstones and siltstones are light to dark grey and highly carbonaceous. The uppermost member of the Clipper Formation is the Coal Measures member. This is defined by a decrease down hole in resistivity response and an increase in sonic interval transit time. This corresponds to a change in the mudstone and siltstone lithologies and the development of coal interbeds. The coals are black and vitreous. This member is dominated by light grey to medium brown, carbonaceous and non-calcareous mudstones and siltstones. The depositional environment during deposition of the Clipper Formation is inferred to range from alluvial fan at the base to fluvio-deltaic near the top. A paralic influence is suggested by marine dinoflagellates within the interbedded unit (Simpson, 1993)

\section{B. Katiki Formation}

The Katiki Formation unconformably overlies the Clipper Formation and has been assigned to the Mata Series of the Upper Cretaceous [Piripauan (Mp) to Haumurian (Mh)] 
(Hawkes and Mound, 1984). The top of the Haumurian stage is not defined by a distinctive lithology change but rather by a slight increase in carbonaceous content (Hawkes and Mound, 1984).

The Katiki Formation consists of brownish-grey marine siltstone and mudstone (Figure 2.1). White argillaceous limestone interbeds very occasionally occur throughout the succession (Hawkes and Mound, 1984). Around Resolution-1 and towards the northeast, the Katiki Formation is represented by the Conway Formation (Milne, 1975 ). Towards the southwest, on the margins of the Clipper Sub-basin, the Pukeiwitahi Formation was deposited within the Katiki Formation in an extensive flood plain and coal swamp environment. Around the area of the Endeavour-1 well, the Pukeiwitahi Formation overlies the Zapata Limestone (a thin unit of argillaceous limestone overlying the Galleon Volcanics within the Katiki Formation) (Wilding and Sweetman, 1971). The Pukeiwitahi Formation consists of quartz-rich, gritty coal measures which are restricted to the west and south of Canterbury Basin (Simpson, 1993). Galleon Volcanics consisting of calcareous to non-calcareous tuff were deposited within the Katiki Formation at Galleon-1 where they are about 10m thick (Simpson, 1993). The Herbert Formation consisting of marine sandstones within the Katiki Formation overlies the Pukeiwitahi Formation towards the west of the basin. It possibly disconformably overlies the Pukeiwitahi Formation (Wilding and Sweetman, 1971). The sediments of the Katiki Formation also extend into the Paleocene interval, with a thick section present at Galleon-1 $(\sim 100 \mathrm{~m})$, and thin sequences at Clipper-1 and Endeavour-1. The equivalent of the Katiki Formation at Resolution-1, the Conway Formation is present in the Paleocene interval there in a thin layer.

\section{Conway Formation}

The Conway Formation refers to the massive jarositic siltstone or silty sandstone, found throughout North Canterbury and southern Marlborough (Browne and Field, 1985). These siltstone to silty sandstone sediments were deposited during the Late Cretaceous as part of a relatively uniform succession of sediments along the East Coast of New Zealand, from Canterbury to the East Cape and beyond (Crampton, 1988). Microfauna from the Conway Formation indicate a Haumurian age (Late Cretaceous) (Browne and Field, 1985). The Conway Formation was originally interpreted to have been deposited in nearshore conditions. The presence of the jarosite was considered by Warren and Speden (1978) to 
have been due to the oxidation of authigenic pyrite formed in richly organic sediment in a low-oxygen energy environment. Crampton (1988), on the basis of the fine grained nature of the formation, heavy bioturbation, geochemistry and paleontology, considers the Conway Formation to have been deposited in a low energy environment at inner shelf to uppermost slope depths, under restricted oceanic conditions during the Late Cretaceous, in agreement with studies done by Moore (1989) on the similar Whangai Formation in the East Coast Basin.

\subsubsection{Paleogene Formations}

Sediments of the Dannevirke Series overlie the Katiki Formation. These sediments are largely characterised by a succession of relatively homogenous mudstones and siltstones and occasional sandstones (Haskell, 2000). The following is summary of the formations present and relevant to the offshore Canterbury Basin.

\section{A. Otepopo Greensand Formation}

The lowest formation in the Dannevirke series sediments is defined by the Otepopo Greensand Formation (Hawkes and Mound, 1984; Wilding and Sweetman, 1971) inferred to have been deposited during the Early Teurian (Dt). At Clipper-1 the top of the Otepopo Greensand Formation was picked at a slight decrease in the gamma ray and resistivity response (Hawkes and Mound, 1984). The formation is light grey to light grey/brown glauconitic siltstone with occasional very fine grained argillaceous sandstones and light grey-brown, non-calcareous mudstones (Hawkes and Mound, 1984). Although initially this formation was proposed to have been present in the Clipper-1 well, subsequent revisions of the lithostratigraphy at that well have included this layer into the Moeraki Formation (Field and Browne, 1989a; GNS, 2009). The Otepopo Greensand overlies the Katiki Formation at the north of Katiki beach and although it has long been viewed as Paleocene, it has recently produced at least one specimen of the Haumurian ammonite Kossmaticeras bensoni (Strong and Hollis, 2009). 


\section{B. Moeraki Formation}

The Moeraki Formation consists of an interbedded succession of dark grey, carbonaceous, pyretic mudstones, grading to dark brown siltstones (Figure 2.1) (Hawkes and Mound, 1984). It was deposited during the Teurian (Dt) to Mangaorapan (Dm) and lies above the Otepopo Greensand Formation at Moeraki Point in the west. Southwards towards Dunedin, the Moeraki Formation is present as its correlative, the Abbotsford Formation (Field and Browne, 1989a). Towards the northeast (Resolution-1), it grades/interfingers with the Charteris Bay Sandstone (Haskell, 1989a) (Figure 3.4 D). It appears to be best developed towards the centre of the basin and at Clipper-1 is 581m thick (Field and Browne, 1989a). The depositional setting inferred from microfaunas indicate near shore settings at Clipper1, Galleon-1 and Endeavour-1 (Raine et al., 1994).

\section{Charteris Bay Sandstone}

The Charteris Bay Sandstone is a fine grained sandstone that is of Paleocene age at its type locality at Charteris Bay, and at the Resolution-1 offshore well (Milne, 1975 ). At

Resolution-1, the Charteris Bay Sandstone had excellent porosity and permeability but was hydrodynamically flushed. The microfaunas within the interval at Resolution-1 indicate it was deposited in higher energy conditions than its equivalents in the other parts of the basin. At Charteris Bay, in its type section, it consists of $1 \mathrm{~m}-2 \mathrm{~m}$ thick beds of glauconitic sandy siltstone and sparse carbonaceous and flaser bedded silty sandstone interbedded with yellow-grey, well sorted, fine to medium quartz sandstone. At Castle Hill Basin, within the Canterbury Basin, brown, fine to very fine sandstone with horizons of abundant shallow water marine molluscs towards the base (two thick Ostrea-dominated shellbeds) lie just above the unconformable base of the Charteris Bay Sandstone (Strong and Hollis, 2009). The Charteris Bay Sandstone is prognosed to be present at the onshore Salmon-1 well site due to the thicker nature of sediments at that level (Tag Oil Ltd, 2007). The Charteris Bay Sandstone was long thought to interfinger/ grade into the Moeraki Formation southwards (e.g., Haskell 1989a; Field and Browne 1989a; Figure 2.1), but seismic interpretation in this study suggests that the Moeraki Formation onlaps against the Charteris Bay Sandstone (Chapter 3). The Charteris Bay Sandstone was previously dated as Cretaceous as it was believed that the rare large prismatic shells from the oyster-beds within it at Castle Hill Basin were Inoceramus (Cretaceous). However, these were later shown to be Isognomon (Paleocene) by Crampton (1988), and subsequently the Charteris Bay Sandstone was dated 
as Paleocene (Strong and Hollis, 2009). The microfauna from the Charteris Bay Sandstone at Resolution-1 indicate it is of Teurian age (Haskell, 1989a). GNS (2009) suggests that the Charteris Bay Sandstone at Resolution-1 is Early Teurian (Early Paleocene). The depositional environment originally inferred for the Charteris Bay Sandstone at Resolution-1 was non-marine to very marginally marine as the majority of the sands there yielded no foraminifera (Hornibrook et al., 1975). However, GNS (2009) considers the environment of deposition to be in marine settings due to the presence of dinoflagellates in the sands (Raine, J.I., pers. comm.). These dinoflagellates also indicate that deposition was in shelf settings.

\section{Tartan Formation}

The Tartan Formation in this study refers to a Late Paleocene, thin organic rich layer that is present in three wells in the offshore Canterbury Basin. There has been a lot of work done on the equivalents of the Tartan Formation which is reviewed here as this relates to depositional environments during the Late Paleocene. This layer, in the well completion reports and other earlier studies (Crux, 1984; Gibbons and Fry, 1986; Gibbons and Jackson, 1984; Hawkes and Mound, 1984; Jackson, 1982; Kamp, 1991; Wilding and Sweetman, 1971; Wilson, 1985) was interpreted to be a correlative of the Waipawa Black Shale, a similar organic rich layer present in the East Coast Basin. In addition, similar, Late Paleocene organic rich mudstone/ siltstone layers have been recorded in Northland (Isaac et al., 1994), northern Taranaki (Killops et al., 1994; King and Thrasher, 1995), Canterbury (Field and Browne, 1989a; Killops et al., 1997) and the Great South Basin (Cook et al., 1999; Raine et al., 1993). The Waipawa Formation is the term now widely used to refer to this Late Paleocene organic rich layer in New Zealand's sedimentary basins with reference to the Waipawa Black Shale of the East Coast Basin (Field and Uruski, 1997; Hollis et al., 2005; Hollis et al., 2006; Killops et al., 2000; Killops et al., 1996; Rogers et al., 1999; Rogers et al., 2001). Schioler et al., (2009) referred to this unit as the Tartan Formation in both the Great South Basin and the Canterbury Basin, and showed that the organic rich layer can be correlated between the two basins. This Late Paleocene organic rich layer was deposited regionally around New Zealand and this regional Late Paleocene deposition is shown in Figure 2.4. In keeping with the proximity of the Great South Basin and the Canterbury Basin, and the stratigraphic position of the shale over the two basins, the name Tartan Formation is maintained in this study. 
The age of the Waipawa Formation has been considered to be Mid to Late Paleocene (61.7-55.8 Ma) (Moore, 1988). Foraminifera record a Mid to Late Teurian age for the top of the Waipawa (Black Shale) Formation, and this lies just below the benthic foraminiferal extinction event that dates the Teurian-Waipawan boundary (Paleocene- Eocene boundary) (Kaiho et al., 1996; Kaiho et al., 1993; Killops et al., 2000). The base of the Waipawa Black Shale lies above the base of the foraminiferal zone P4 and climate cooling at 59.1 Ma (Figure 2.5; Killops et al., 2000). Although more precise dating of the age and duration of deposition of the Tartan Formation and its equivalents is difficult, assuming constant depositional rates throughout the Teurian at particular sites indicated the Waipawa Black Shale was deposited over $\sim 1.5$ ma (between 57.5-56 Ma) (Killops et al., 2000). More recent work has constrained the age of this formation to within the Thanetian (Late Paleocene, 58.7-55.8 Ma; Figure 2.5) (Crouch, 2001). This age is similar to the age obtained for samples of the Tartan Formation from the Great South Basin by Schioler et al., (2009), and further suggests that the Waipawa Black Shale and the Tartan Formation and its equivalents are coeval.

The Tartan Formation and its equivalents have both marine and terrestrially derived organic matter (Cook et al., 1999; Hollis et al., 2006; Killops et al., 1997; Schiøler et al., 2009). Meadows (2009) studied the geochemical characteristics of the Tartan Formation in the Canterbury Basin and concluded a mixed terrestrial and marine source for the organic matter present within. This is in agreement with geochemical studies done on the Waipawa Black Shale which is also seen to have a mixed terrestrial and marine contribution to its organic content (Hollis et al., 2000; Moore, 1989; Moore et al., 1987; Rogers et al., 1999). However, the Tartan Formation deposited in the Canterbury Basin differs from the Waipawa Formation deposited in the East Coast Basin by having a greater Total Organic Carbon (TOC) content and higher $\delta^{13} \mathrm{C}$ values (Meadows, 2009).

The Tartan Formation, and its equivalent in the East Coast Basin, the Waipawa Black Shale, are generally believed to have been deposited under dysaerobic conditions (Hollis et al., 2000; Killops et al., 2000; Killops et al., 1996; Schiøler et al., 2009). Dysaerobia is a term applied to a depositional environment with $0.1-1.0 \mathrm{ml}$ of dissolved oxygen per litre of water. Geochemical evidence cited for dysaerobic conditions during deposition of the Waipawa Black Shale are the presence of abundant sulphur and the large range of its 
isotopic fractionation and the negative $\delta^{34} \mathrm{~S}$ values for kerogen and bitumen which indicates an unrestricted supply of fresh sulphate, and is also consistent with anoxia in open marine conditions (Killops et al., 2000). The presence of the benthic foraminifera Elongate nodosariids recorded at many sites within the Waipawa Black Shale is also indicative of dysaerobia (Kaiho, 1991), as is the presence of the foraminifera Alabamina (Kaiho, 1994). A depositional environment with low oxygen and high organic content resulting from environmental stress is also proposed as a cause for the foraminifera Haplophragmoides dominated assemblages commonly obtained from the Waipawa Black Shale (Strong et al., 1995). Low diversity, agglutinated and stressed fauna from the Waipawa Black Shale also points to dysaerobic conditions during deposition of the Waipawa Black Shale (Killops et al., 2000; Moore, 1989). However, the occurrence of limited bioturbation and restricted numbers of benthic fauna within the Waipawa Black Shale indicate that the sediment surface was not completely anaerobic.

The exact cause of the dysaerobic conditions is unclear with different mechanisms being proposed. Killops (2000) suggests dysaerobia could have been caused by high biological oxygen demand due to biological scavenging and reworking of descending organic matter causing reduced oxygen saturation levels within the water due to biochemical degradation. A change in circulation from thermohaline to halothermal circulation could have also caused an oxygen depleted water body below 200m (Killops et al., 2000). Changing oceanic circulation patterns in the Late Paleocene which culminated in a major extinction of benthic organisms at the Teurian-Waipawan (Paleocene-Eocene) Stage boundary is the mechanism believed by some workers to have caused deposition of the organic rich Waipawa Black Shale and its equivalents around New Zealand (Killops, 1996; Field and Uruski, 1997).

Killops (2000) regards marine upwelling to be the most likely source of nutrients causing increased biological activity and subsequently leading to dysaerobia. The relatively abundant presence of radiolarians and diatoms in New Zealand through the CretaceousTertiary transition, in contrast to their sparse numbers in age equivalent sites globally is also seen to indicate a regional upwelling along the eastern continental margin of $\mathrm{New}$ Zealand (Hollis, 1996; Hollis, 1991; Killops et al., 2000). Although restricted bottom water circulation is a potential cause for dysaerobic conditions, it is unlikely to be the main cause of deposition of the Waipawa Black Shale due to its contemporaneous deposition over 
many basins around New Zealand (Field and Uruski, 1997). It is more probable that degradation of organic matter below an area of high phytoplankton productivity, resulting from upwelling led to organic rich sediments deposited around New Zealand (Field and Uruski, 1997). Although Field and Uruski, (1997) state that no evidence for such high productivity across the New Zealand continent has been recorded they also observe that high productivity is a potential cause of the organic concentration and preservation in the Waipawa Black Shale. Killops (1996) suggested anaerobia developed rapidly after the initial dysaerobic conditions, on the basis of the benthic fauna, gamma ray logs, sulphur content, isotopic composition and geochemical characteristics of the Waipawa Black Shale. High primary productivity during deposition could have occurred simultaneously during periods of high sea level preceded by a glacio-eustatic fall. This glacio-eustatic fall is marked by dropstones in the Upper Calcareous member of the upper Whangai Formation that underlies the Waipawa Formation at Angora Stream and Riversdale in the East Coast Basin (Leckie et al., 1995).

Although the Waipawa Black Shale was initially proposed to have been deposited in very shallow lagoonal or estuarine conditions (Moore, 1988), later workers have generally agreed that deposition of the Waipawa Black Shale was fairly deep settings, corresponding to inner shelf to basal slope/ abyssal environments and below the limit of wave action (Killops et al., 2000; Killops et al., 1996). However, shallower depths of deposition have been suggested for the deposition of the Tartan Formation in the Great South Basin, based on seismic evidence for a ridge near the sea surface from Late Cretaceous to Paleocene times, which extended along the line of the wells in the Great South Basin in which the Tartan Formation was identified (Killops et al., 2000). According to some workers, deposition here occurred in a relatively shallow and restricted marine environment (Raine et al., 1993). Recent work by Schioler et al., (2009) also indicates deposition of the Tartan Formation in the Great South Basin to have been in marginal marine settings with a water depth of $\sim 0 \mathrm{~m}-20 \mathrm{~m}$. Evidence for a major change of depth leading to, and contemporaneous with, the deposition of the Tartan Formation is not evident (Killops et al., 2000; Strong et al., 1995). The fine-grained nature of disseminated quartzose material and agglutinated foraminiferal fauna (Leckie et al. 1992) supports the deepwater origin of the Waipawa Formation in the East Coast Basin. 
The deposition of the Waipawa Black Shale with respect to sea level is not altogether clear. Some have stated that it represents a condensed section that was likely to have been developed at the peak of marine transgression or a highstand following a major lowering of the Late Paleocene sea-level (Haq et al., 1987; Rogers et al., 2001; Strong et al., 1995). It is also inferred by some to have been deposited in the Late Paleocene, during a third-order, eustatic sea-level rise occurring between a climatic cooling at 59.1 Ma and a thermal maximum at $55.5 \mathrm{Ma}$, and during a transition from cold to warm-saline deep-water circulation in the South Pacific with deposition occurring around most of the land mass and generally near the shelf break (Killops et al., 2000). Evidence for a climate of exceptional warmth over the Paleocene comes from oxygen isotope and temperature records obtained from the Ocean Drilling Project (ODP) around the Southern Ocean. This transient climate which is inferred to have lasted only for around $100 \mathrm{kyr}$ was a time of 'global warming' estimated to have started in the Middle Paleocene (Zachos et. al., 2003). The period of time around the Paleocene-Eocene boundary is also generally believed to have been a time of global transgression and increasing temperatures, with temperatures reaching their highest at the boundary (Field et al., 1997). During this time paleontological proxy records show near sub-tropical conditions at high latitude marine and terrestrial sites (Zachos et al., 1993). Major benthic foraminiferal extinctions were also recorded at the time coinciding with this Late Paleocene to Early Eocene warming (Kennett and Stott, 1991). This Late Paleocene to Early Eocene planetary warming was preceded by a period of cooling recorded on benthic oxygen isotopic records and also seen as an isotopic carbon excursion on benthic carbon isotope records, which Corfield and Cartlidge (1992) called the Paleocene Carbon Isotope Maximum (PCIM). The eustatic sea-level curve of Haq et al., (1987) shows the interval coinciding with the PCIM as undergoing a significant lowering of sea level indicating a period of regression.

According to Schioler et al., (2009), the Tartan Formation was deposited during a peak regression in the Late Paleocene (58.7-55.8 Ma) which gave way to a transgression in the Great South Basin. Analysis of their work on palynofacies and geochemistry shows that the upper part of the Wickliffe Formation, which underlies the Tartan Formation in the Great South Basin, was deposited in proximal settings under subnormal to hyposaline conditions. Samples from the Tartan Formation also had a high percentage of degraded marine phytoclasts which also indicated deposition in a proximal, marginal marine setting with a strong influx of terrestrial organic matter. Phytoclast percentages of the overlying 
Laing Formation were lower than the two underlying formations (Tartan and Wickliffe), while elevated percentages of marine algae cysts and AOM were recorded. The regressive nature of the Tartan Formation was seen by a substantial increase in its non marine proxies and the top of the formation was interpreted to be a maximum regressive surface. Comparison of the results of the Tartan Formation from the Great South Basin with the Waipawa Formation at the Te Hoe section along the East Coast Basin showed similar results in terms of palynofacies changes through the formation, and this was seen as further corroboration of the regressive nature of deposition of the Tartan Formation and its equivalents (Schiøler et al., 2009). This interpretation agrees with the early proposed models (Moore, 1988, 1989) of deposition of the coeval Waipawa Black Shale of the East Coast Basin as having occurred at shallow marine environments during a regressive phase. The paleogeography of the New Zealand continent at the time of deposition of the Tartan Formation is shown in Figure 2.4.

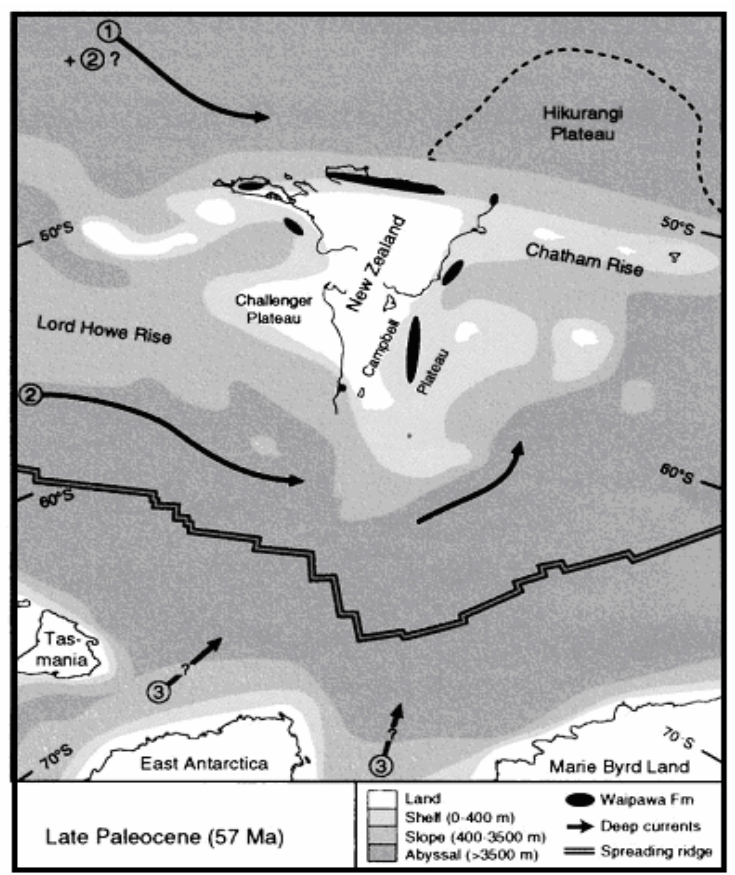

Figure 2.4: Paleogeography of the New Zealand continent with palaeobathymetry and locations of deposition of the Waipawa Black Shale and its equivalent, the Tartan Formation shown. After Killops (2000). 


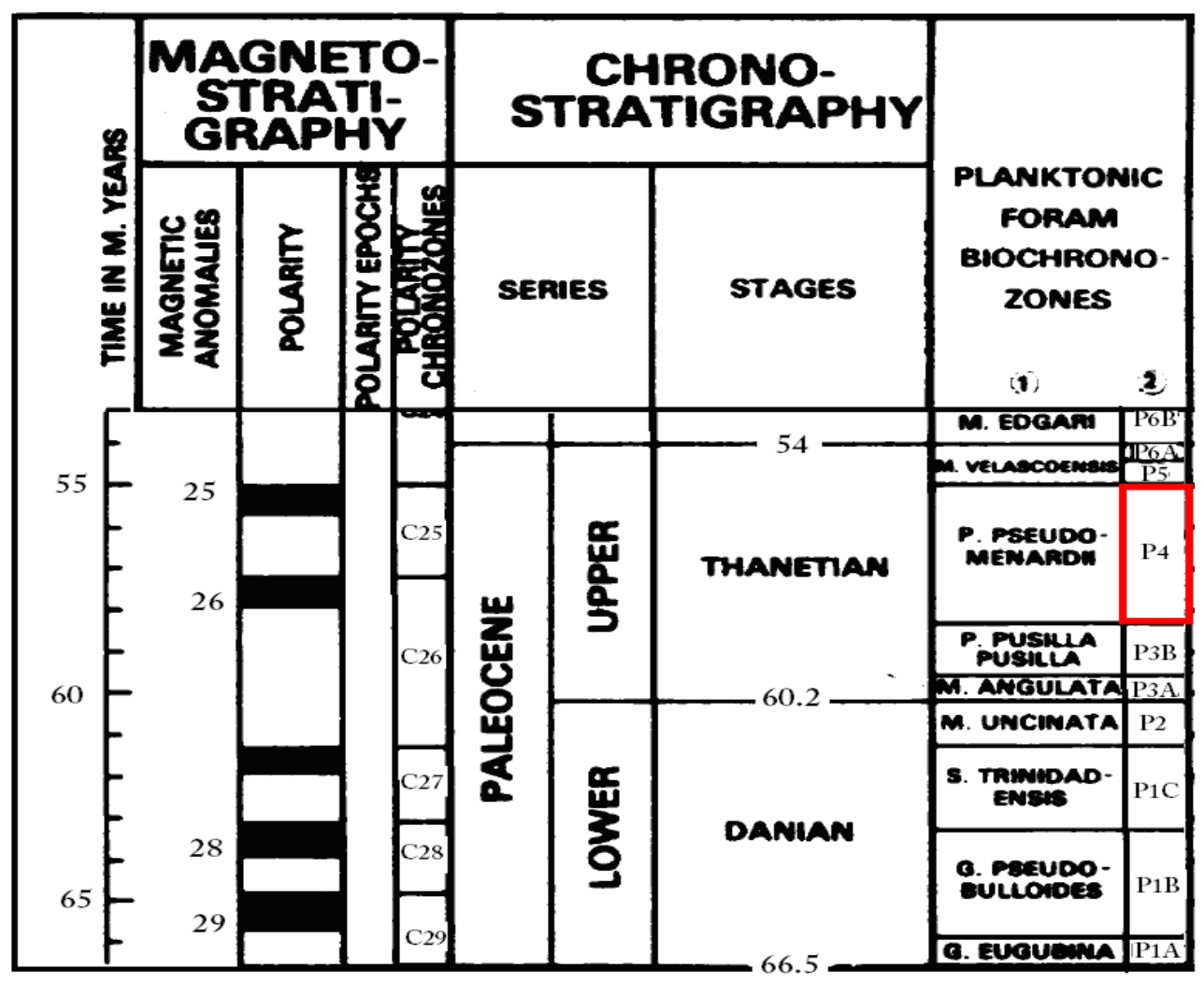

Figure 2.5: Magnetostratigraphy, chronostratigraphy and Planktonic Foram Biochronozones of the Paleocene interval. The P4 foraminiferal zone referred to in the text is boxed in red. After Haq et al., (1987).

\section{E. Hampden Formation}

The Hampden Formation of Bortonian $(\mathrm{Ab})$ to Kaiatan age (Ak) overlies the strata of the Dannevirke series (Figure 2.1). It consists of medium grey to brown micaceous, predominantly calcareous mudstone (Hawkes and Mound, 1984; Wilding and Sweetman, 1971). It is locally referred to as the Ashley mudstone towards the north, around Resolution-1. Simpson (1993) asserts it was deposited in an outer shelf to bathyal paleoenvironment. Originally the Hampden Formation was split into two units, the lower one being called the Hampden Formation and the upper one called the Mokihi Formation equivalent (Hawkes and Mound, 1984). However, Field and Browne (1989a) suggested that the two new units be incorporated into the one Hampden Formation. A subsequent revision of the biostratigraphy at the four offshore wells in the Canterbury Basin by GNS (2009) also incorporates both the old units into the Hampden Formation. The Hampden Formation is considered to have been deposited in fairly deep environments relative to the underlying Paleocene sediments, in inner shelf to outer neritic and upper bathyal settings. 


\section{F. Amuri Limestone}

Strata from as early as the Late Eocene to Early Miocene (Whaingaroan (Lwh) to Waitakian (Lw)) are dominantly grouped as the Amuri Limestone (Figure 2.1). At Clipper-1 there is $100 \mathrm{~m}$ of white, firm to hard, microcrystalline, occasionally glauconitic, pyretic limestone and at Endeavour-1 the equivalent section consists of about $10 \mathrm{~m}$ of pale to medium grey, tight, highly glauconitic and very sandy limestone and at Resoution-1 there is a $42 \mathrm{~m}$ thick Amuri Limestone sequence (Simpson, 1993).

The microfaunas within the Amuri Limestone together with its fine texture suggest an outer shelf or slope paleoenvironment (Simpson, 1993; Field and Browne, 1989a). The Amuri Limestone is widely regarded to represent sediment starvation during the time of maximum transgression over the New Zealand continent, with limestones being deposited by default (Carter, 1985; Carter et al., 1982; Fulthorpe et al., 1996). In certain places the Amuri Limestone is absent due to erosion and this is seen as an unconformity of Upper Whaingaroan age (Field and Browne, 1989a). This is a widespread unconformity and recognisable rarely on seismic sections where angular truncation is evident.

\section{G. Otekaike Limestone}

This limestone is of Duntroonian age and is similar to the Amuri Limestone except for containing occasional dolomitic laminae (Field and Browne, 1989a). The Otekaike Limestone is interpreted by Field and Browne (1989a) to have been deposited in an intrashelf basin setting and deposition continued into the Early Miocene. The sandy basal sediments of the Tokama Siltstone consisting of fine, sandy siltstones overlie the Otekaike Limestone and is interpreted by Field and Browne (1989a) to have been deposited in a mid-neritic paleoenvironment and to be a correlative of the Rifle Butts Formation (Figure 2.1) identified towards the southwest section of the Canterbury Basin (towards Endeavour1)

\section{H. Tokama Siltstone}

This, together with its correlatives is the dominant lithology from the Middle Miocene to Recent (Simpson, 1993; Figure 2), Field and Browne (1989a; Appendix 1-profile G), and Crown Minerals (2008; Figure 1). The Tokama siltstone is a blue-grey silty fine sandstone 
and siltstone (Field and Browne, 1989a; Gregg, 1959) and variably calcareous (Figure 2.1). Gregg (1959) inferred from the fauna within the Tokama siltstone, that deposition occurred at offshore settings.

\subsection{Previous Knowledge of Paleogene Interval (Seismic Reflectors)}

Seismic Reflectors of various lateral extents have been mapped in the Paleogene interval by Mound (1984), Hawkes and Mound (1984) and other authors mentioned below. These horizons correspond to:

- Oligocene Horizon

- Late Paleocene Horizon, and

- $\quad$ Base of Paleocene Horizon

These reflectors are summarised below.

Oligocene Horizon: - The velocity contrast at the base of the widespread, Late EoceneOligocene limestone (Amuri Limestone) correlates with the Oligocene horizon (Field and Browne, 1989a). The base of the limestone is time-transgressive and has also been mapped approximately as unconformities of Oligocene to Miocene age that locally mark the removal of the limestone by erosion and due to this the geological interpretation of the horizon is complex (Field and Browne, 1989a). It is the green horizon mapped by Perry (1991).

The Oligocene limestone is absent at Endeavour-1 and Leeston-1. It coincides with the base of a Miocene limestone at Endeavour-1 and with the base of a unit of Miocene volcaniclastic sediment at Leeston-1. This Oligocene horizon is the green horizon mapped by BP Shell Todd (1984) and records a down-sequence decrease in acoustic velocity. On the Chatham Rise the horizons variously mapped as the Middle Tertiary unconformity and Oligocene Limestone by Wood et al., (1989) is tied to the Oligocene horizon (Field and Browne, 1989a). The limestone in this region is relatively thin and locally absent due to erosion. This horizon also correlates to the green horizon mapped by Haskell (1989a).

Late Paleocene Horizon: - This horizon coincides with the middle of a $45 \mathrm{~m}$ thick organic rich unit of shale at Clipper-1 and is of probable Teurian age within the Moeraki 
Formation (Field and Browne, 1989a). It is tied to a Teurian carbonaceous mudstone unit near the top of the Katiki Formation at Galleon-1 and was thought by Hawkes and Mound (1984) to record a zone of organic rich sediment. It is possible that this horizon is the Tartan Formation horizon mapped in this study (Chapter 3). However at that time it was not recognised as such. Herzer and Wood (1989) and Wood et al., (1989) mapped it as the top Paleocene. Haskell (1989a) mapped a horizon close to this level as the orange horizon. However, the well ties were to the top of a thick Paleocene interbedded lava and tuff sequence at Endeavour-1 (top Endeavour Volcanics), to a hard tuffaceous sandstone at Resolution-1 (View Hill Volcanics of this study) and to a shale break at or near the top of the Paleocene at Clipper-1. This horizon of Haskell (1989a) is more likely to represent the top of the volcanics (Endeavour Volcanics and View Hill Volcanics) or to represent the Tartan Formation horizon with wrong well ties.

The red horizon of Anderton et al., (1982) in the Great South Basin is thought to be a direct correlative of this Late Paleocene horizon although no ties have been made (Field and Browne, 1989a).

Mound and Pratt (1984) thought this horizon reflected volcanic activity as correlatives of the View Hill Volcanics of Teurian age occur just below the horizon in Endeavour-1 and traces of ash occur just below it Clipper-1. However, Field and Browne (1989a) suggest that the presence of the volcanics might be coincidental or possibly related tectonically to the cause of the facies change and probable unconformity that is marked by the reflector. It is marked by a down-sequence decrease in acoustic velocity (Field and Browne, 1989a).

Base of Paleocene Horizon: - This horizon is only tied to the Clipper-1 well and occurs near the Cretaceous-Tertiary boundary in the well and is represented by the indigo horizon of Hawkes and Mound, (1984). This horizon is thought to correlate with the unconformity beneath the Otepopo Greensand and Abbotsford Formation of North Otago and with the Conway Formation to Loburn Mudstone contact in southern North Canterbury (Field and Browne, 1989a). Wood et al., (1989) mapped this horizon on the Chatham Rise. It is marked by a down-sequence increase in acoustic velocity (Field and Browne, 1989a). 
Mogg et al., (2008) recognise the top Eocene, top Paleocene and top Cretaceous horizons and these have been mapped locally as part of Origin Energy's strategy for oil and gas exploration in Canterbury Basin. 


\subsection{Regional Seismic Interpretation}

\subsection{Introduction}

Interpretation of seismic data is of fundamental importance to the oil and gas industry as it reveals much about the sub-surface sedimentary architecture and leads to a better understanding of the depositional history of the basin which can subsequently lead to better predictions of hydrocarbon accumulations.

In Canterbury Basin, oil and gas companies have acquired seismic data and most of these are in the public domain. This database of 2D seismic data together with 2D seismic data shot by the Marine Seismic Data Centre at the University of Texas at Austin, and reprocessed seismic lines by Origin Energy were used for regional seismic interpretation of Paleocene and Eocene strata over the offshore Canterbury Basin. This was then followed by more detailed seismic facies analysis and mapping out of more detailed reflectors and packages which helped to further constrain the depositional history of the Canterbury Basin. This chapter details the seismic mapping and interpretation of the PaleoceneEocene strata along with changes in their seismic expression and thickness.

\subsection{Principles of seismic sequence and facies analysis}

Seismic reflection is the most important tool in offshore sedimentary basin interpretation as it provides information on a regional scale (Sheriff, 1976). Seismic stratigraphy and seismic facies analysis have evolved since they were first described and published in the 1970's. Since then they have proven to be very useful for the development of depositional models for sub-surface formations. Seismic reflections are the result of acoustic impedance contrasts of physical surfaces in sub-surface rocks (Brown Jr and Fisher, 1980). These physical surfaces such as unconformities or stratal boundaries (bedding surfaces) represent changes in the property of rocks in the subsurface, such as density, and accordingly seismic waves are reflected by these boundaries. The aim of seismic reflection interpretation is to construct a model of the geological history of the basin by correlating sequence geometries and determining the mechanisms that cause the geometries (Snedden 
and Sarg, 2008). These mechanisms that affect the seismic architecture are eustacy, subsidence, sediment influx and tectonics.

The interpretation of seismic reflection data proceeds by first recognising depositional sequences. A depositional sequence is "a relatively conformable succession of genetically related strata bounded at its top and base by unconformities or their correlative conformities" (Mitchum, 1977). These sequences are genetically related and are packaged chronostratigraphically and therefore very useful for stratigraphic interpretation (Vail et al., 1977). A sequence is deposited during an interval of time determined by the ages of the top and bottom of the sequence and these sequence boundaries are determined by recognising reflector terminations. These reflector terminations are illustrated in Figure 3.1.

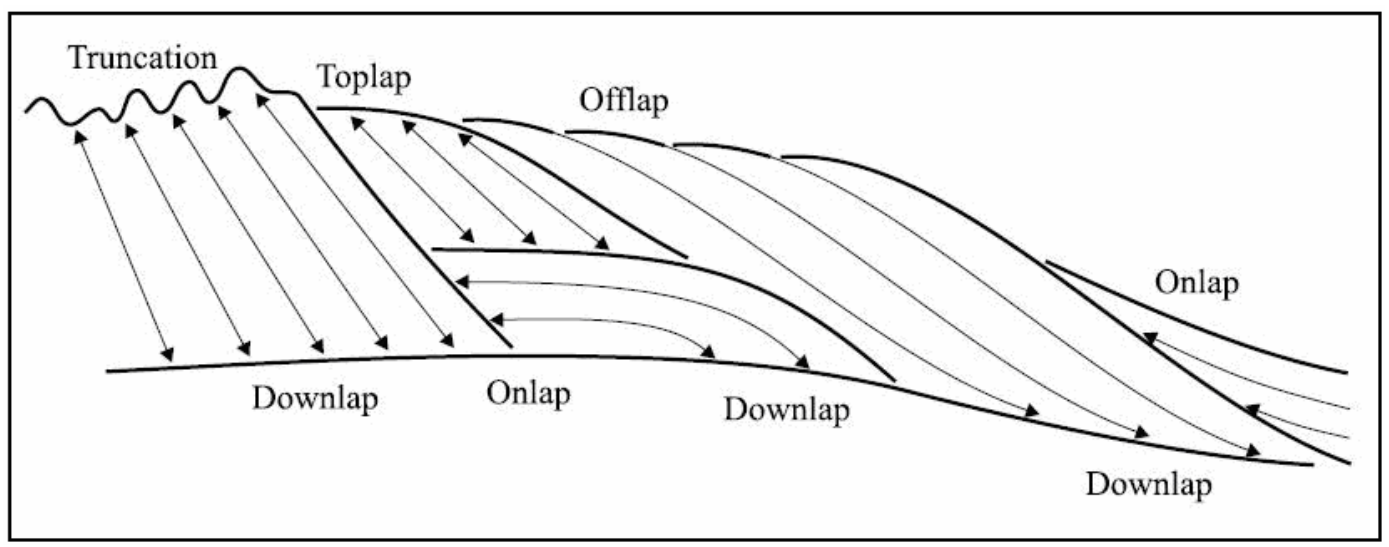

Figure 3.1: Types of reflector terminations defining unconformable boundaries. After (Catuneanu, 2002).

After seismic sequences are delineated, smaller reflection units within the depositional sequence are examined. The aim of this facies analysis is to interpret the reflections with respect to stratification, lithology and the characteristics of the depositional environment (Roksandic, 1978). These seismic facies are described based on their reflector configuration, amplitude, continuity, frequency, interval velocity and external form. 


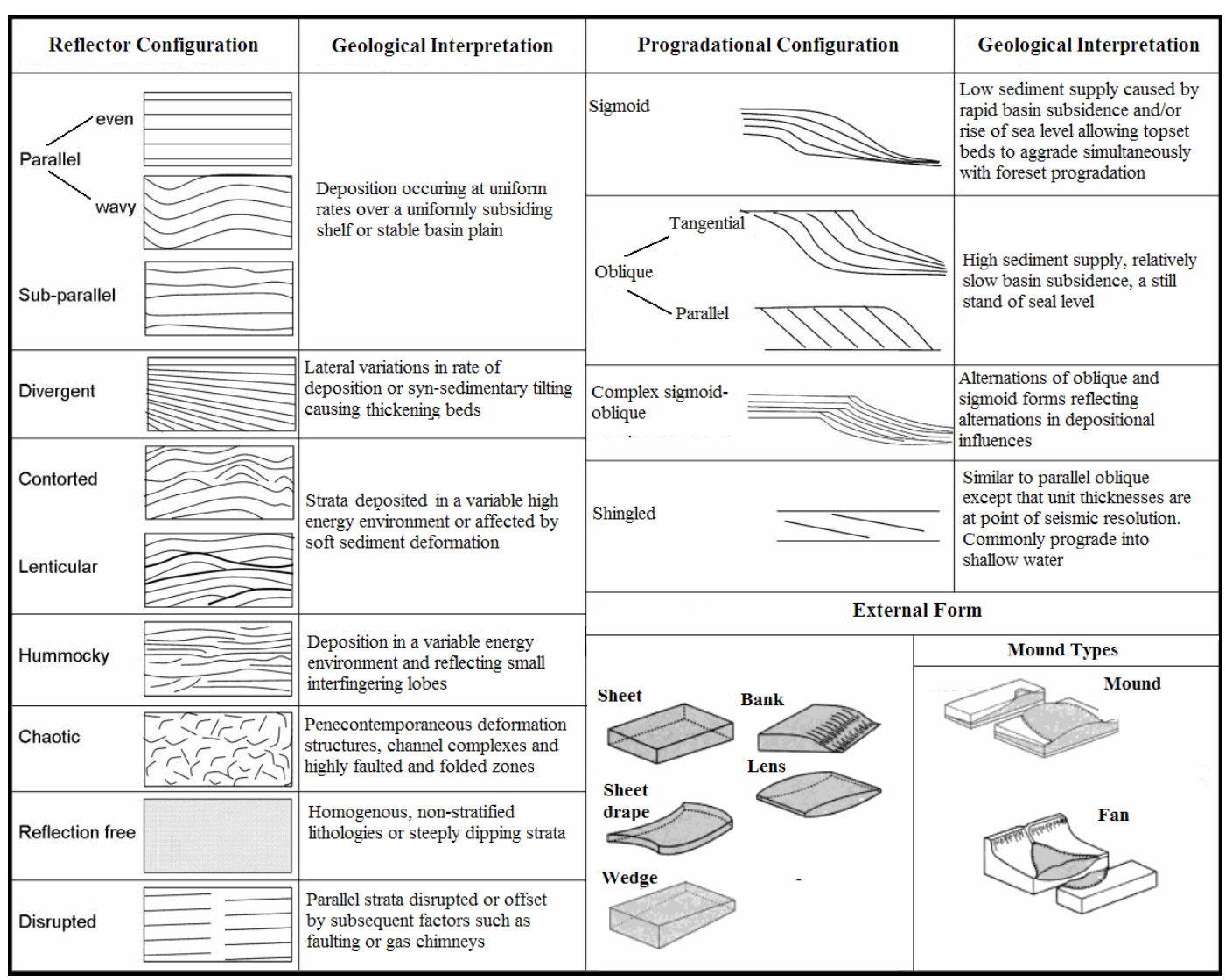

Figure 3.2: Configuration of typical reflection patterns, their geological interpretations and external forms. Modified from Mitchum et al., (1977) and Allen and Allen (2005).

Continuity of reflectors generally depends upon the lateral extension of uniform strata related to the continuity of the impedance contrast along unconformities or bedding surfaces. The reflection amplitude is dependant upon contrasts in density and the velocity of the acoustic wave propagation through different lithologies. The reflection amplitude increases with increase in acoustic impedance contrast and vice versa and strong reflection amplitudes are associated with boundaries separating different lithologies or strata.

Frequency, or the distance between reflectors is related to differences in distance between beds and on lateral variations in the velocity of acoustic waves caused by changes in lithology. The interval velocity is dependant on the rock density. The reflector form and internal configuration is often the first parameter that can be observed on seismic profiles and they are affected by the nature of stratification and are associated with particular depositional environments (Figure 3.2). The external, three dimensional form of seismic reflectors is determined by mapping the different seismic facies groups across the seismic datasets and correlating them between neighbouring seismic lines. 
An analysis of these seismic facies and geometries along with integration with other data such as wireline logs and cores makes an interpretation of depositional environment possible.

\subsection{Data}

A database of $12,000 \mathrm{~km}$ of phase-matched 2D seismic data with four wells was used for seismic interpretation (Appendix D). Data was provided by GNS from their Canterbury Basin mapping project (Figure 3.3). Most of the seismic lines come from BP Shell Todd's regional survey shot in 1982 . These are the $\mathrm{CB}-82$ lines and they were shot by Western Geophysical and processed by Digicon (Perry, 1991). Some of these lines were reprocessed by Origin Energy and these lines were incorporated into the study. The EW0001 seismic data available from the Marine Seismic Data Centre at the University of Texas at Austin was also incorporated into the study (Appendix D). There is no 3D seismic data available of the offshore Canterbury Basin. Petroleum wells drilled in the offshore Canterbury Basin are Galleon-1, Endeavour-1, Clipper-1, Resolution-1 and Cutter-1, and information for all wells except Cutter-1 is open-file. All well data was checked for consistency with the data available in well completion reports. Well information was incorporated from revised biostratigraphy and a review of formation tops and sidewall core data (Appendix B; Section 5.4). Well data included in this project includes location, total depths, depth datums, time-depth curves, deviation data, wireline log curves, formation tops and Stage boundaries (Appendix E; Appendix G). 


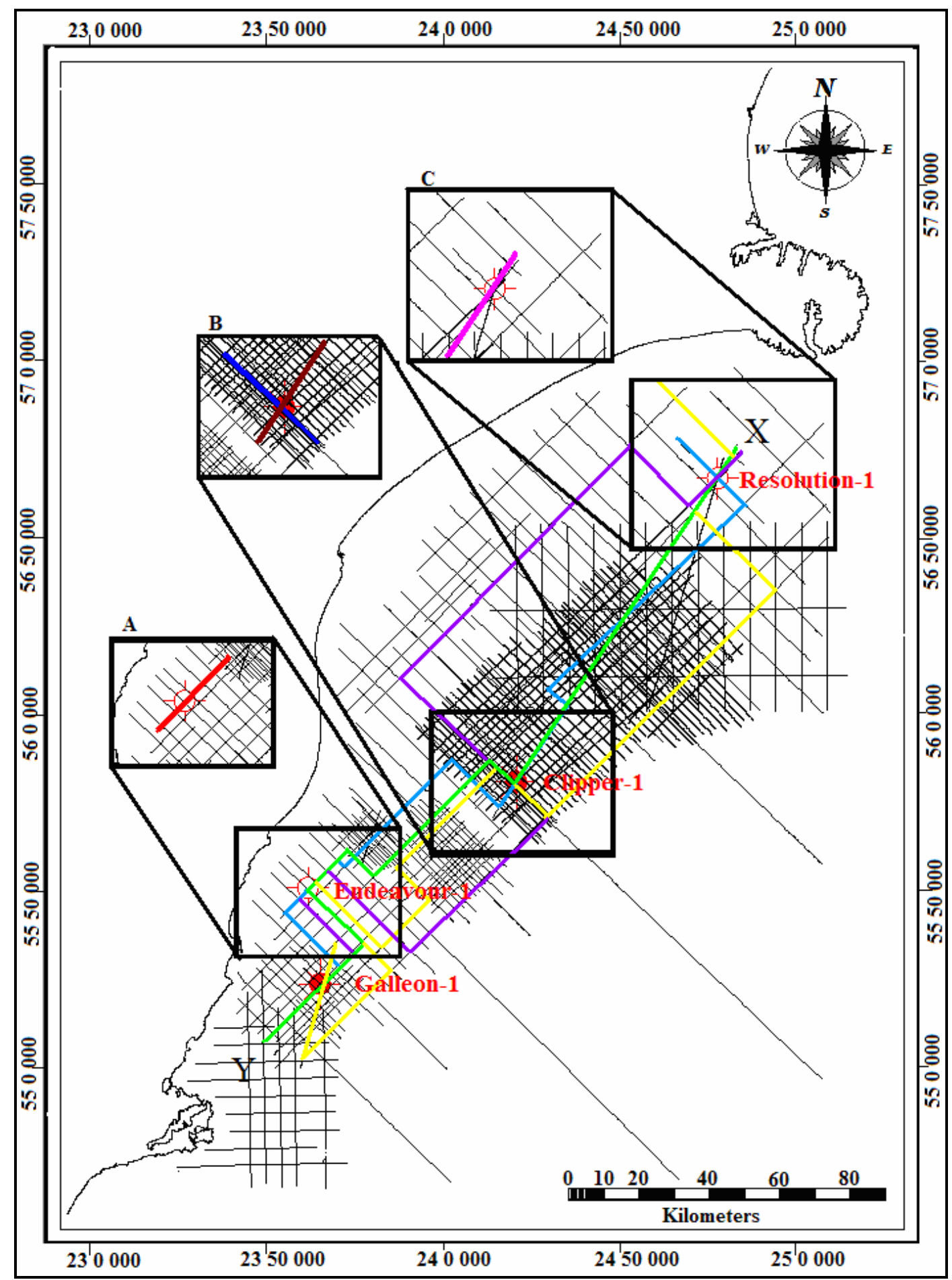

Figure 3.3: Map showing the seismic dataset interpreted upon with well locations shown. The four coloured lines show the location of the regional composite lines created. Green coloured composite line (XY) is shown in Figure 3.4. Inset A: Location of seismic line CB82-17 (red) shown in Figure 3.5 and Figure 3.8. Inset B: Location of seismic line ANZ001 (dark brown) and CB82-52b (navy blue) shown in Figure 3.7 and Figure 3.9 respectively. Inset C: Location of seismic line ANZ-001 (pink) shown in Figure 3.11. 


\subsection{Interpretation Methods}

Standard seismic interpretation methods were performed with Zokero Seisware 7.1 seismic interpretation software on a Dell Precision 390 workstation. The following steps were performed for the regional interpretation of Paleogene strata:

1. Wells were calibrated to seismic lines and well-to-seismic ties were cross checked by correlation of stratigraphic markers between wells.

2. Where a poor well-to-seismic tie was seen, well tops were rechecked with updated well data from GNS Science and updated information on formation tops and chronostratigraphic horizon depths (Section 5.4).

3. As there were three different datasets used, seismic to seismic ties were done using key stratigraphic markers and seismic datasets were time shifted accordingly.

4. Four regional composite lines were created from surveys of different quality and vintages. These lines intersect the four wells drilled in this offshore part of the basin (Figure 3.3). One regional composite line (XY) is shown in Figure 3.4.

5. Seven seismic horizons were mapped over these four composite lines. These horizons correspond to the near base Oligocene, near top Paleocene, top Tartan Formation, base Tartan Formation, top Charteris Bay Sandstone, base Charteris Bay Sandstone and near top Cretaceous.

6. From these composite lines a broad loop of tied seismic lines was created.

7. The coarse grid was then mapped in more detail along the infill lines that connect with the broad loop and composite lines.

8. Faults offsetting Paleocene and Eocene sediments were interpreted. In general faulting was seen to be minimal within the Paleocene and Eocene sequence in the study area.

9. At areas where seismic interpretation was difficult such as at faults, across seismic lines of different vintages and surveys, or across null traces, the seismic reflectors were checked according to the character of the overall sedimentary package using correlation polygons and loop ties.

10. First pass structure contour maps were created as an initial quality check to observe obvious cases of seismic horizon mis-interpretations such as bull's eyes in areas where it is not geologically reasonable. The mis-interpreted lines were then rechecked using loop ties and ties to the key composite lines intersecting wells. Structure contour maps were then created again. 
11. Final two-way travel-time (TWTT) structure maps of interpreted horizons were gridded using a minimum curvature method constrained to a polygon of the study area, with a grid spacing of $1000 \mathrm{~m}$ and smoothed once. These grids correspond to the seismic surface formed by interpolating between the seven horizons. Contours were generated with a spacing of 50 milliseconds (ms).

12. Isochron maps were then created by calculating TWTT isochrons between two interpreted horizons and were then gridded. Time to depth conversion of the interpreted seismic data was beyond the scope of this project. 


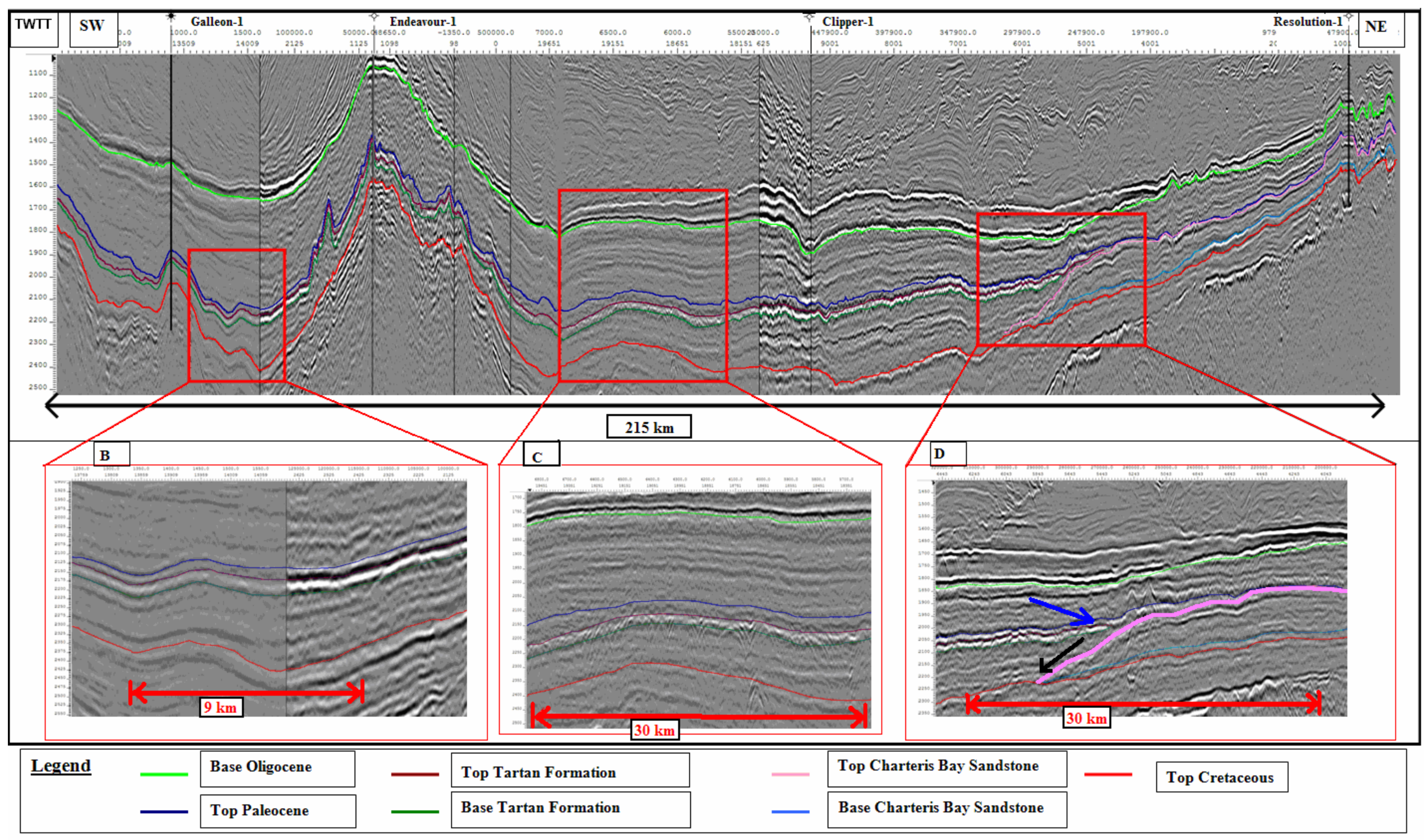

Figure 3.4: (A) Composite regional seismic line XY (line location shown in Figure 3.3) with interpreted horizons showing changes in seismic character with detail over key seismic facies changes. (B) Inset showing the general stratigraphic relationship

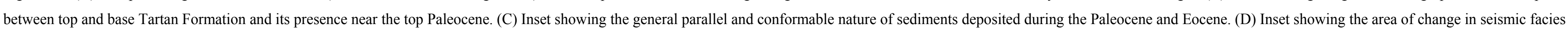
between Resolution-1 and Clipper-1, interpreted pinch-out of the Tartan Formation (blue arrow) and downlap of the Charteris Bay Sandstone (black arrow). 


\subsection{Interpreted horizons}

Seven seismic horizons were interpreted throughout the area of study to characterise the sedimentary succession of interest to this project. Three horizons represent New Zealand Epoch boundaries (near top Cretaceous, near top Paleocene and near base Oligocene). The remaining four horizons represent lithostratigraphic boundaries (top and base Tartan Formation and top and base Charteris Bay Sandstone). Formation tops and Stage boundaries were revised according to new analysis of biostratigraphy by previous workers and a review of the data in this study (Chapter 5, Section 5.4). Accordingly, this interpretation differs from previous work. These horizons are described in more detail below and the seismic reflectors picked are summarised in Table 3.1.

\subsubsection{Near Base Oligocene}

The near base Oligocene horizon is typically marked by an abrupt velocity change at the base of the Amuri Limestone, a Late Eocene to Oligocene, commonly micritic limestone (e.g., at Galleon-1). This relatively high acoustic impedance contrast gives rise to a high amplitude reflector (Figure 3.5). It is sub-horizontal with a slight seaward dip and was picked as a peak. Due to changes in seismic surveys and quality, and processing methods, the character (amplitude and frequency) of the near base Oligocene reflector varies. However it is present as the highest amplitude reflector in the stratigraphic section of interest over the entire study area. The near base Oligocene reflector is time transgressive and in places marks the erosional removal of the Oligocene limestones (e.g., at Endeavour1). The establishment of the circum-Antarctic current during the Oligocene due to the opening of the ocean between Australia and Antarctica is thought to have caused local and even widespread erosion of the sea bottom (Carter, 1985). This coupled with local uplift is inferred to be the cause of the absence of the Oligocene limestone at Endeavour-1 and here this reflector is inferred to represent the erosional surface. Due to the impedance contrast between the Oligocene limestones and the underlying mudstones, the reflector was picked with a high level of confidence. Further southwest the reflector is associated with a bright package that consists of prominent reflectors which individually appear and disappear, but the package is traceable through the south and into the Great South Basin, it loses amplitude and its particularly bright character but is still traceable (Figure 3.6). 


\begin{tabular}{|c|c|c|c|c|}
\hline $\begin{array}{l}\text { Reflector } \\
\text { Name }\end{array}$ & $\begin{array}{l}\text { Reflector } \\
\text { Type }\end{array}$ & NZ Stage & $\begin{array}{l}\text { Age } \\
\text { (Ma) }\end{array}$ & Seismic to Well Tie \\
\hline $\begin{array}{l}\text { 1) Base } \\
\text { Oligocene }\end{array}$ & Peak & Top Ar-Ak & $34.3-36$ & $\begin{array}{l}\text { Prominent peak aligning with } \\
\text { biostratigraphic pick and } \\
\text { associated with the base of the } \\
\text { Late Eocene to Oligocene } \\
\text { Amuri Limestone }\end{array}$ \\
\hline $\begin{array}{l}\text { 2) Top } \\
\text { Paleocene }\end{array}$ & Trough & Top Dt & 55.5 & $\begin{array}{l}\text { Picked at the reflector aligning } \\
\text { with the top Paleocene depth } \\
\text { determined from revised } \\
\text { biostratigraphy at wells. }\end{array}$ \\
\hline $\begin{array}{l}\text { 3) Top } \\
\text { Cretaceous }\end{array}$ & Trough & Top Mh & 65 & $\begin{array}{l}\text { Picked at the reflector aligning } \\
\text { with the top Cretaceous depth } \\
\text { determined from revised } \\
\text { biostratigraphy at wells. }\end{array}$ \\
\hline $\begin{array}{l}\text { 4) Top } \\
\text { Tartan } \\
\text { Formation }\end{array}$ & Trough & Late $\mathrm{Dt}$ & $<55.5$ & $\begin{array}{l}\text { This reflector occurs within the } \\
\text { Moeraki Formation at } \\
\text { Endeavour-1 and Clipper-1 } \\
\text { and at its base in Galleon-1. It } \\
\text { is associated with a sharp GR } \\
\text { high and was picked at the } \\
\text { corresponding reflector. }\end{array}$ \\
\hline $\begin{array}{l}\text { 5) Base } \\
\text { Tartan } \\
\text { Formation }\end{array}$ & Trough & Late $\mathrm{Dt}$ & $<55.5$ & $\begin{array}{l}\text { This reflector occurs within the } \\
\text { Moeraki Formation at } \\
\text { Endeavour-1 and Clipper-1 } \\
\text { and at its base in Galleon-1. It } \\
\text { is associated with a sharp GR } \\
\text { high and was picked at the } \\
\text { corresponding reflector. }\end{array}$ \\
\hline $\begin{array}{l}\text { 6) Top } \\
\text { Charteris } \\
\text { Bay } \\
\text { Sandstone }\end{array}$ & Trough & $\begin{array}{l}\text { Early to } \\
\text { Middle Dt }\end{array}$ & $<55.5$ & $\begin{array}{l}\text { This reflector occurs within the } \\
\text { Paleocene interval at } \\
\text { Resolution-1. It is associated } \\
\text { with a sharp GR low and was } \\
\text { picked at the corresponding } \\
\text { reflector. }\end{array}$ \\
\hline $\begin{array}{l}\text { 7) Base } \\
\text { Charteris } \\
\text { Bay } \\
\text { Sandstone }\end{array}$ & Trough & Early Dt & $>65$ & $\begin{array}{l}\text { This reflector occurs within the } \\
\text { Paleocene interval at } \\
\text { Resolution-1. It is associated } \\
\text { with a sharp GR low and was } \\
\text { picked at the corresponding } \\
\text { reflector. }\end{array}$ \\
\hline
\end{tabular}

Table 3.1: Seismic reflector information list. 


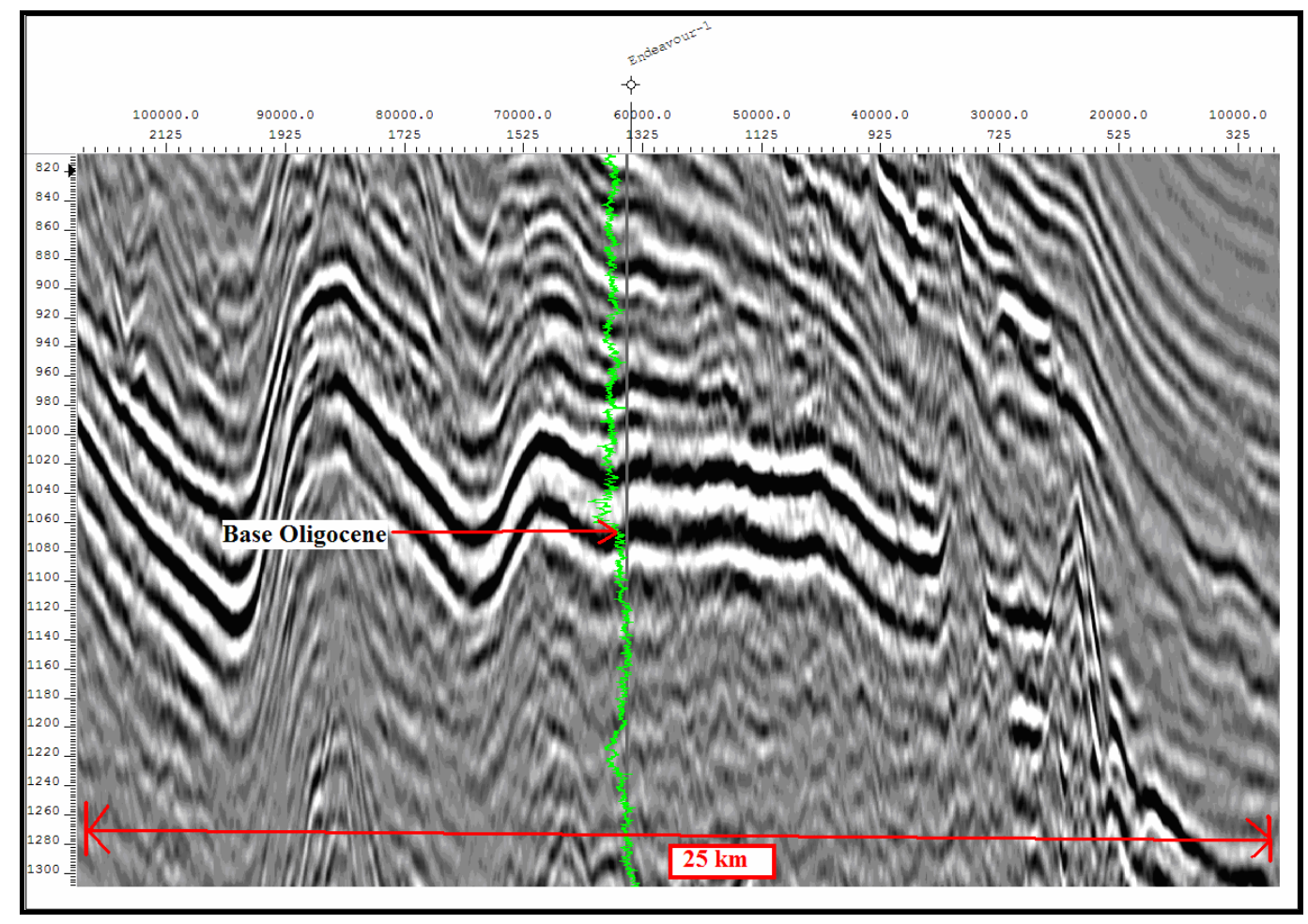

Figure 3.5: Uninterpreted seismic line CB82-17 through Endeavour-1 showing the typical high amplitude seismic response of the base Oligocene reflector due to the large impedance contrast between the overlying limestone and the underlying mudstones. Gamma ray log is superimposed in green. Location of line is shown in Figure 3.3.

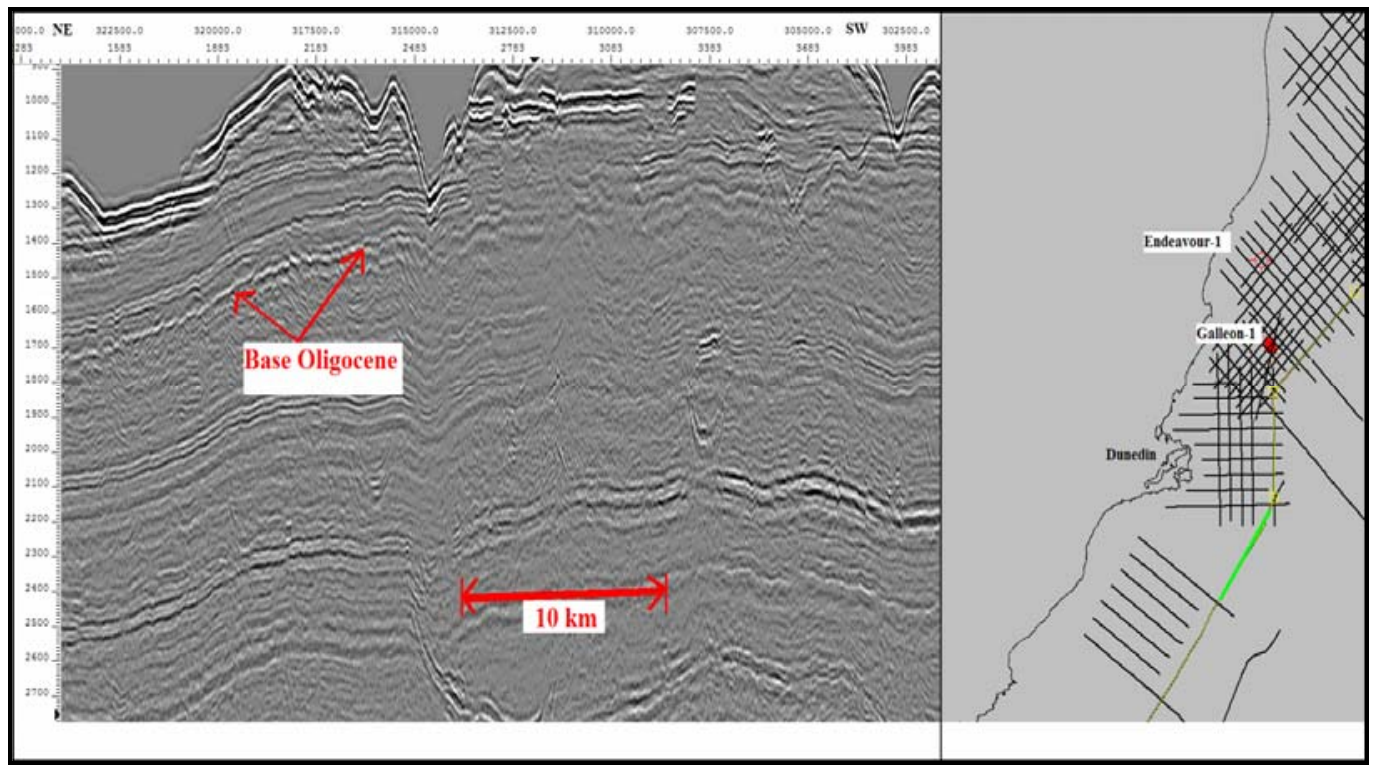

Figure 3.6: Uninterpreted seismic line B210B at the southern margin of the basin showing the change in amplitude of the base Oligocene reflector from NE-SW. Inset shows location of line in green. 


\subsubsection{Near Top Paleocene}

This reflector varies in amplitude across the basin and is best developed in the local area around the Clipper-1 well where it is a moderate amplitude reflector. For this project this reflector was tied to a carbonaceous mudstone of Paleocene age close to the top of the Moeraki Formation at Galleon-1. This same reflector at Clipper-1 coincides with a distinct increased gamma ray response towards the top of the Moeraki Formation just above a $31 \mathrm{~m}$ thick organic rich unit of shale (Tartan Formation). At Endeavour-1 this reflector is tied near the top of a unit of medium to dark grey silty mudstone within the Moeraki Formation and has a slight increase in the corresponding gamma ray response. At Resolution-1 this reflector ties to the top of a volcanic unit, the View Hill Volcanics, a thin volcanic layer just above the top of the Charteris Bay Sandstone (Figure 3.7). In general this is a low to moderate amplitude reflector and is difficult to trace across the basin. This is in agreement with the lithologies encountered in wells showing no marked lithology change at this level that would give rise to a notable impedance contrast. This reflector was picked with moderate confidence around the basin as it does not altogether lose its amplitude even where it appears to fade.

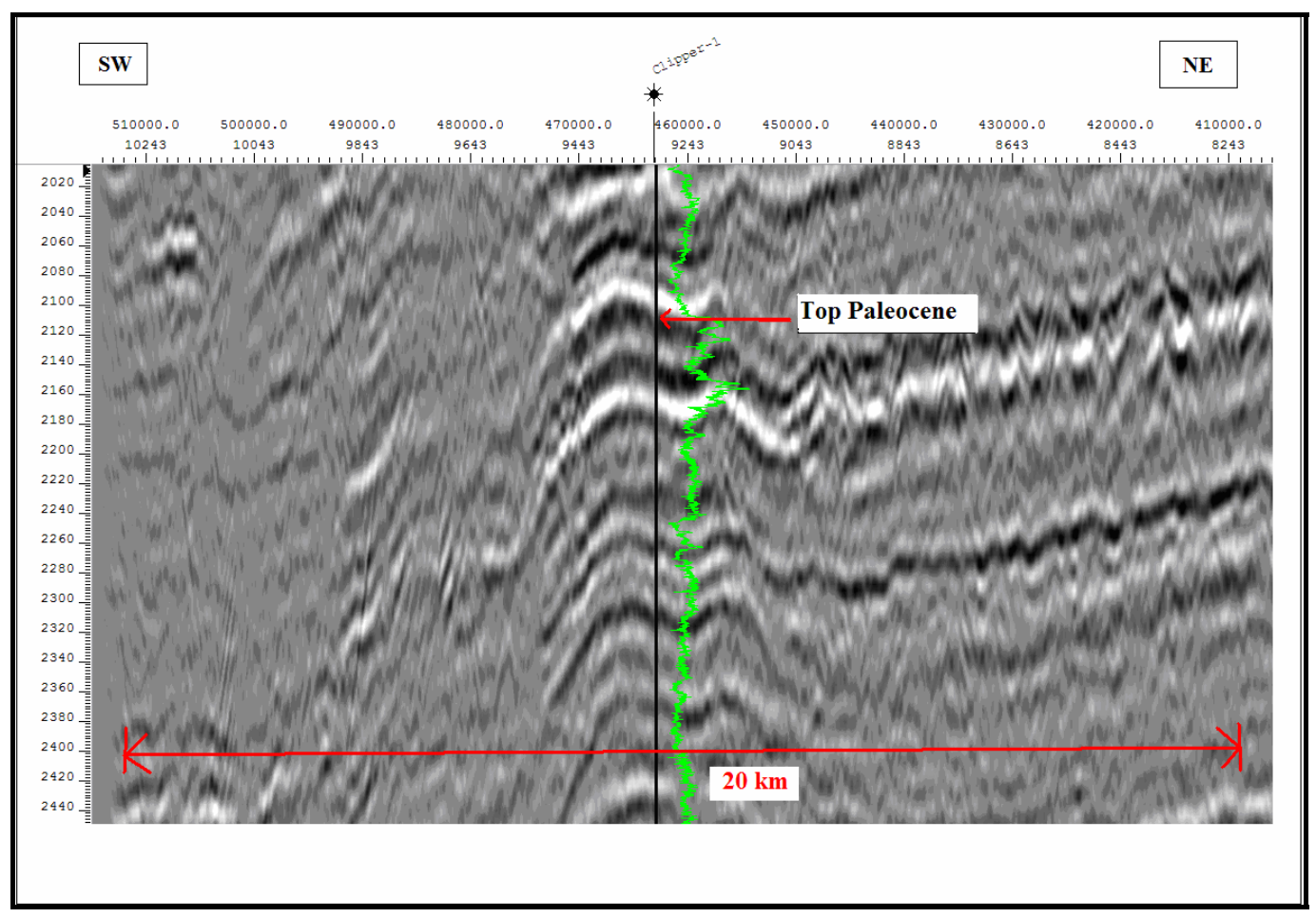

Figure 3.7: Uninterpreted seismic line ANZ-001 through Clipper-1 showing the top Paleocene reflector. Gamma ray log is superimposed in green. Note the moderate amplitude of the reflector and the change in 
amplitude away from the well (to SW). Also seen is the associated increase in the gamma ray response marking the top of the Paleocene. Location of the line is given in Figure 3.3.

\subsubsection{Near Top Cretaceous}

This is a low to moderate amplitude reflector and shows high variability with respect to its amplitude. This reflector is difficult to trace due to its low amplitude and in parts of the basins seems to disappear entirely before reappearing (Figure 3.8). Therefore this reflector was picked with less confidence. This reflector at Clipper-1 is tied just below the base of a volcanic unit, the Endeavour Volcanics. At Galleon-1 it ties to the middle of a unit of mudstone within the Katiki Formation. At Endeavour-1 it ties to near the base of the Lower Moeraki Formation and at Resolution-1 it ties to near the top of the Conway Formation.

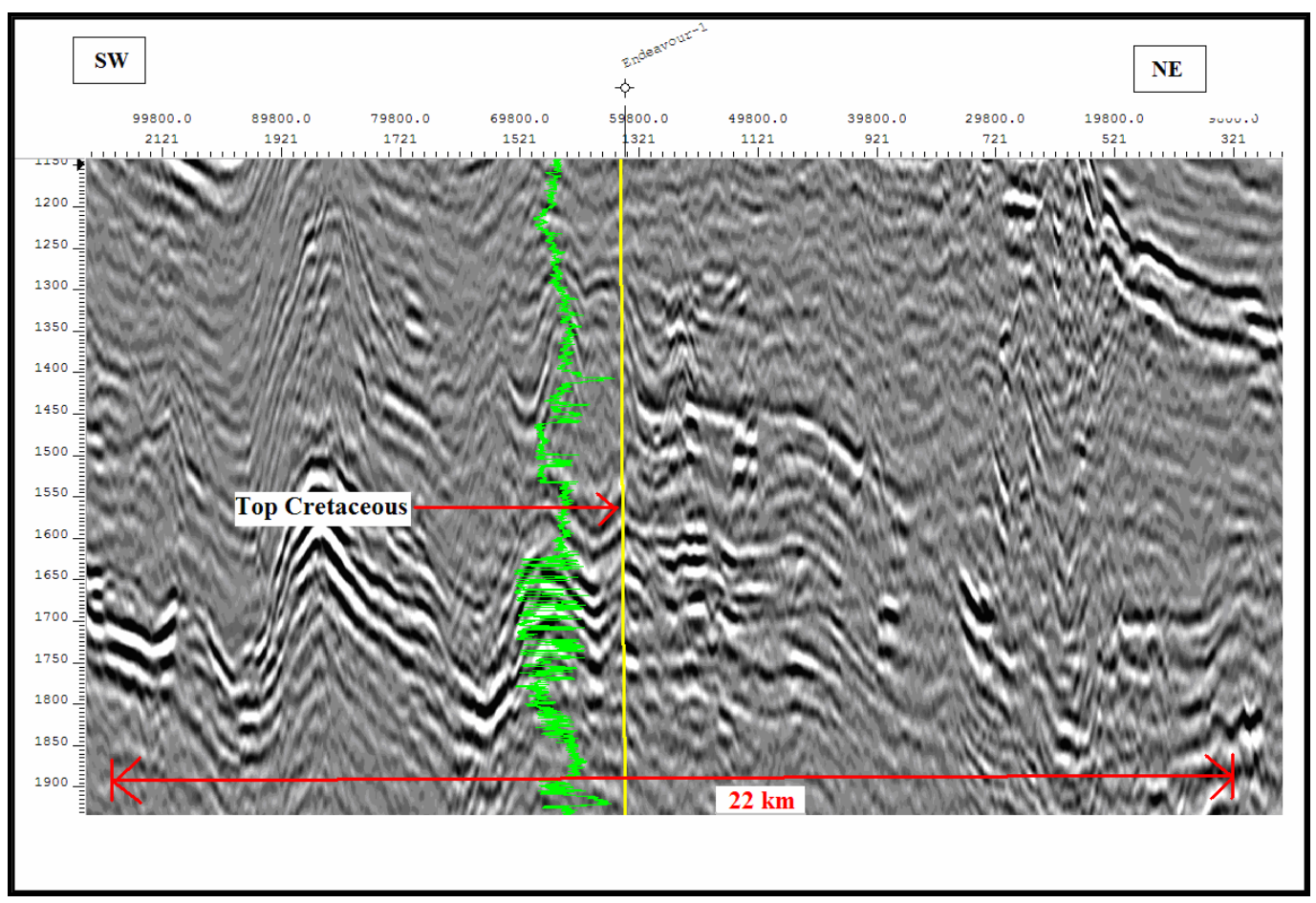

Figure 3.8: Uninterpreted seismic line CB82-17 through Endeavour-1 showing the well pick of the top Cretaceous and its corresponding seismic reflector. Gamma ray log is superimposed in green. Note the variation in amplitude of this reflector across the line and no significant gamma ray response associated with it. Location of line is given in Figure 3.3.

\subsubsection{Top Tartan Formation}


The Top Tartan Formation reflector is a relatively moderate to high amplitude reflector and closely follows the near top Paleocene reflector. The amplitude varies across the basin and this reflector is best developed around the local area of the Clipper-1 well where it is of moderate to high amplitude. This horizon was picked from the Galleon-1 well pick where there is a jump in the gamma ray response at the top of this formation. The Tartan Formation is a potential source rock in the adjacent Great South Basin and in Canterbury Basin is seen to be organically rich from examination of the sidewall core samples (Section 4.2.3; Figure 4.1). On wireline logs it appears as a kick in the gamma ray log (Figure 5.1). This formation was laid down in the same biostratigraphic interval as the Waipawa Black Shale Formation in the East Coast Basin where it is present as a source rock. On seismic, wireline logs and core samples the Tartan Formation is present at Galleon-1, Endeavour-1 and Clipper-1 and absent at Resolution-1.

On seismic, the Tartan Formation is seen to pinch-out towards the north towards Resolution-1 above the Charteris Bay Sandstone (Figure 3.4 D; Figure 3.12; Figure 3.13; Figure 3.14). This is in agreement with wireline logs and sidewall core samples at Resolution-1 where this Formation is seen to be absent.

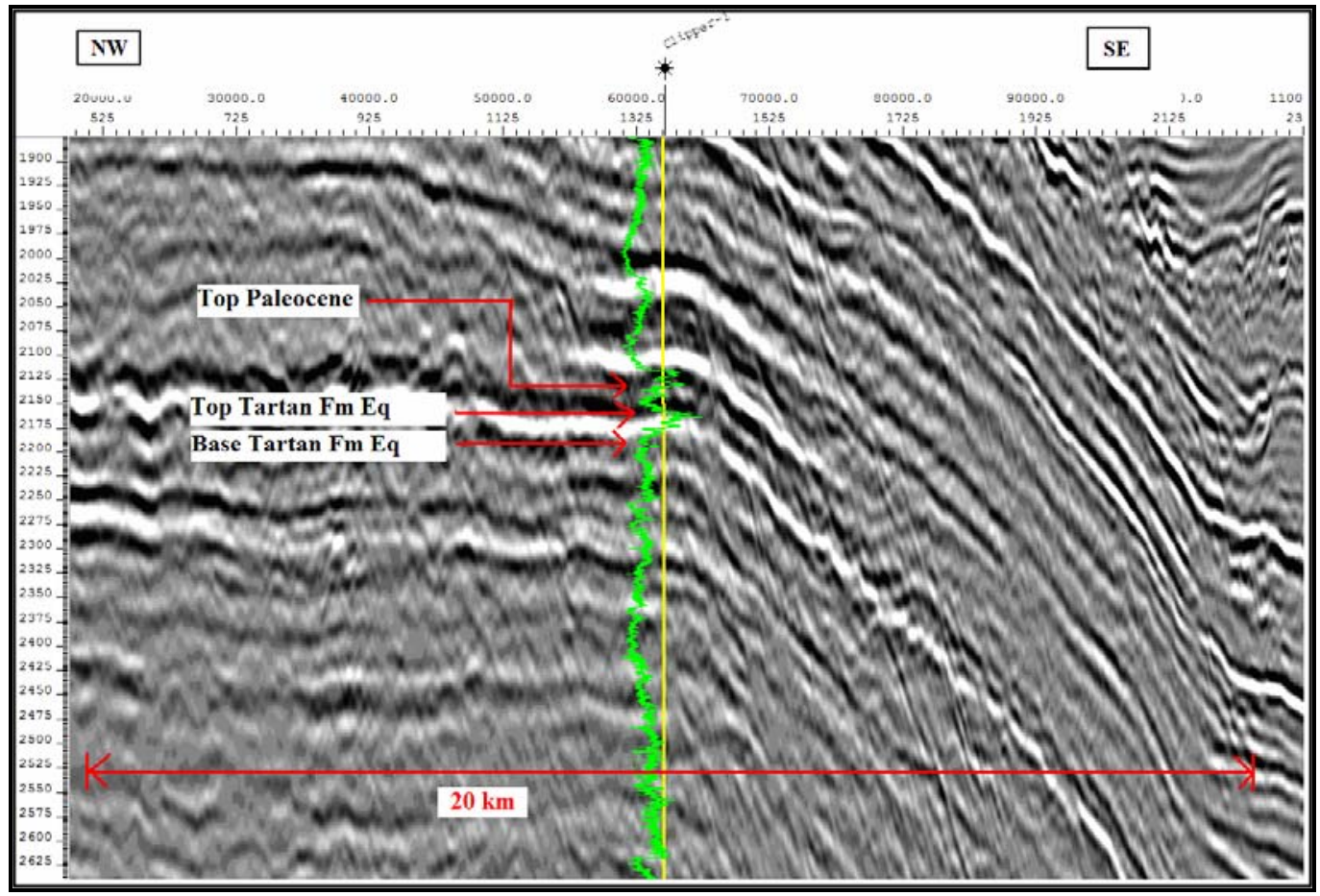

Figure 3.9: Uninterpreted seismic line CB82-52b through Clipper-1 showing the reflector associated with the top and base of the Tartan Formation. Gamma ray log is superimposed in green. Note the bright package 
associated with the Tartan Formation at Clipper-1 and the associated increase and decrease in gamma ray response down hole marking the top and base respectively of the Tartan Formation. Location of line is given in Figure 3.3.

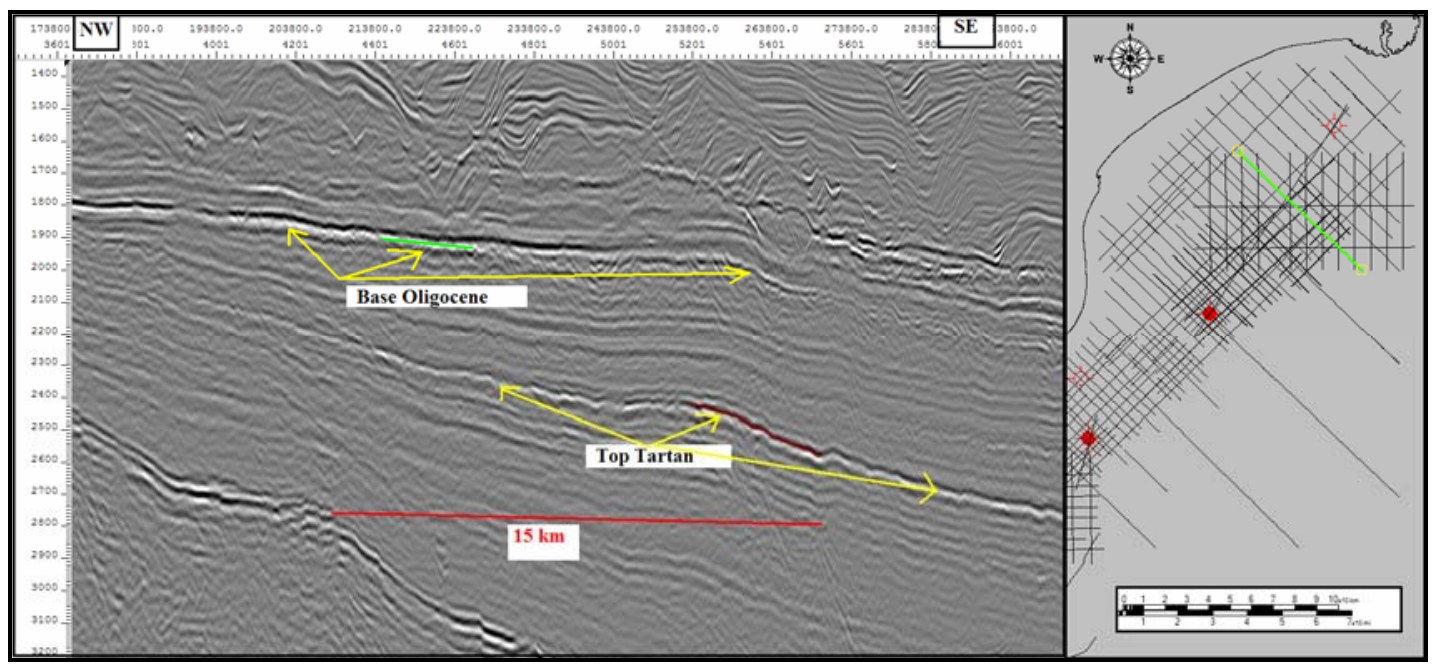

Figure 3.10: Seismic line CB82-20 showing amplitude changes of the base Oligocene reflector and top Tartan Formation reflector. The base Oligocene reflector loses amplitude towards the southeast and the top Tartan Formation reflector loses amplitude towards the northwest. Also note subtle onlap seen above the top Tartan reflector and towards the northwest.

\subsubsection{Base Tartan Formation}

This is a relatively moderate to high amplitude reflector and was traced out across the basin except in the northeast (towards Resolution-1) where it pinches out. This reflector was mapped out from wells where the well picks are defined (Galleon-1, Endeavour-1 and Clipper-1). It marks the base of a relatively bright, thin package on seismic and corresponds to the base of an organic rich unit within the Moeraki Formation (Figure 3.9).

On the gamma ray log it appears as a decrease down hole from its high over the Tartan Formation interval.

\subsubsection{Top Charteris Bay Sandstone}

Fine sandstones with excellent porosity were encountered at Resolution-1 and defined biostratigraphically to be of Paleocene age. The reflector corresponding to the top of the Charteris Bay Sandstone is defined at Resolution-1 and was picked from the well and mapped out as a trough (Figure 3.11). The reflector is not present over the whole study area but is localised around the area of Resolution-1. The thickness of sediment separating 
the View Hill Volcanics (the base of which is picked as the top Paleocene at Resolution-1) from the top of the Charteris Bay Sandstone package is almost below seismic resolution, so over a substantial area where the Charteris Bay Sandstone package is present, the corresponding reflector aligns with the top Paleocene reflector. The divergence is at the area where the top Charteris Bay Sandstone reflector downlaps onto the top Cretaceous reflector (Figure 3.4 D; Figure 3.12; Figure 3.13; Figure 3.14). The downlap surface is of moderate amplitude and has been mapped along many other lines. This interpretation from seismic is in agreement with lithology from the wells where the Charteris Bay Sandstone is absent in all wells except Resolution-1. The gamma ray log also shows a blocky motif with a decrease and increase down hole indicating sandstones separated by a thin volcanic layer. This volcanic layer is inferred on the basis of the gamma ray response and on identification of the volcanic layer in sidewall cores (Figure 3.11).

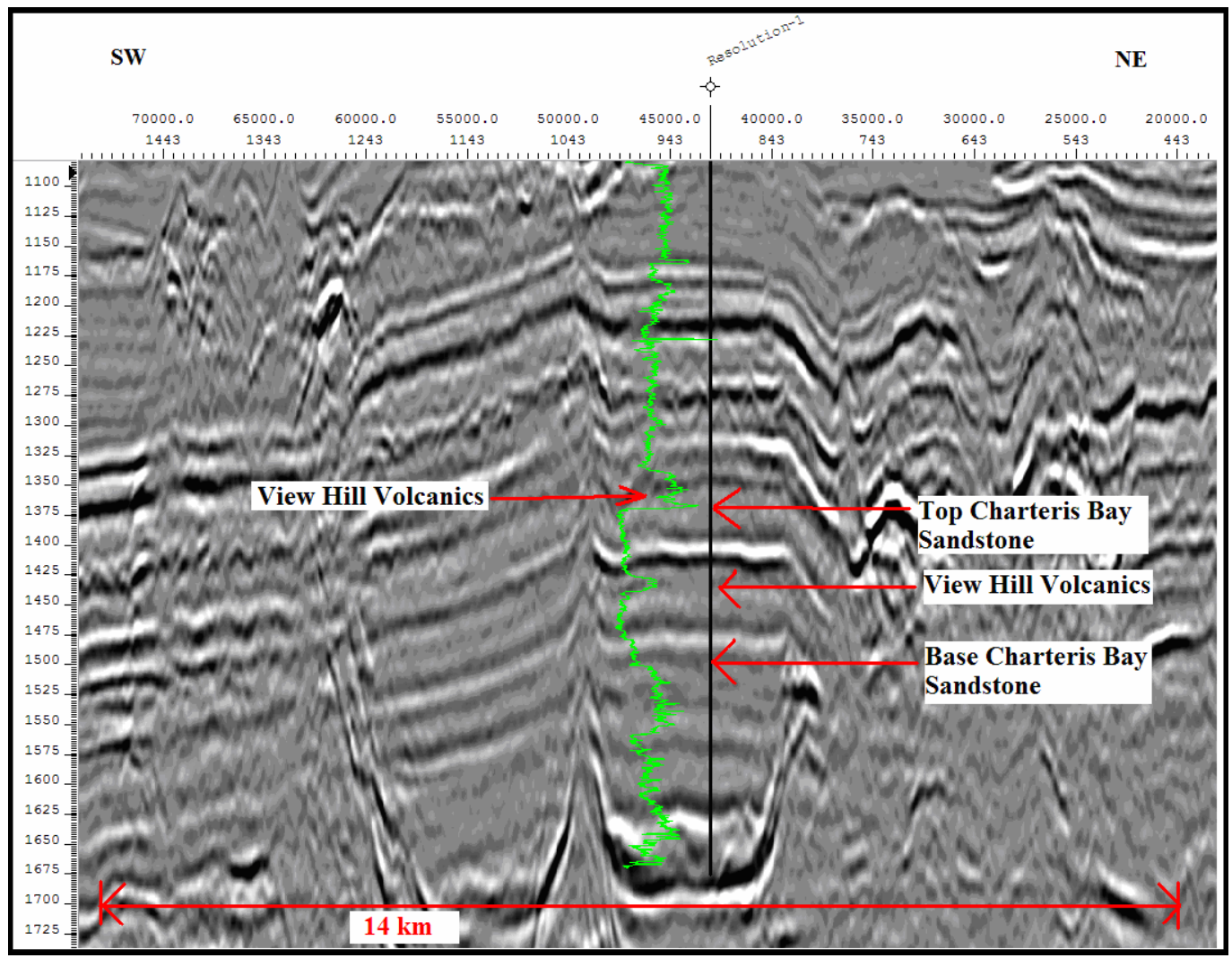

Figure 3.11: Uninterpreted seismic line ANZ-001 showing the top and base of the Charteris Bay Sandstone defined at the Resolution-1 well. Note the sudden increase and decrease down hole of the gamma ray response marking the top and base of the Charteris Bay Sandstone. Also seen is the gamma ray response of the thin intervening volcanic layer, the View Hill Volcanics within the Charteris Bay Sandstone seen as a sudden increase and decrease in the gamma ray response down hole, and a thin layer of the View Hill Volcanics above the Charteris Bay Sandstone. Location of line is given in Figure 3.3. 


\subsubsection{Base Charteris Bay Sandstone}

The base of the Charteris Bay Sandstone was picked on seismic at the reflector coinciding with a sudden increase down hole in the gamma ray response. This is seen to mark the base of the Charteris Bay Sandstone package and a return to finer grained mudstones of the Conway Formation below. This is a moderate amplitude reflector and was picked as a trough (Figure 3.11). Similar to the top of the Charteris Bay Sandstone, this reflector appears to downlap onto the top Cretaceous reflector or to merge with it (Figure 3.4 D). This reflector extends around the local area of the Resolution-1 well and marks the base of a sandy package.

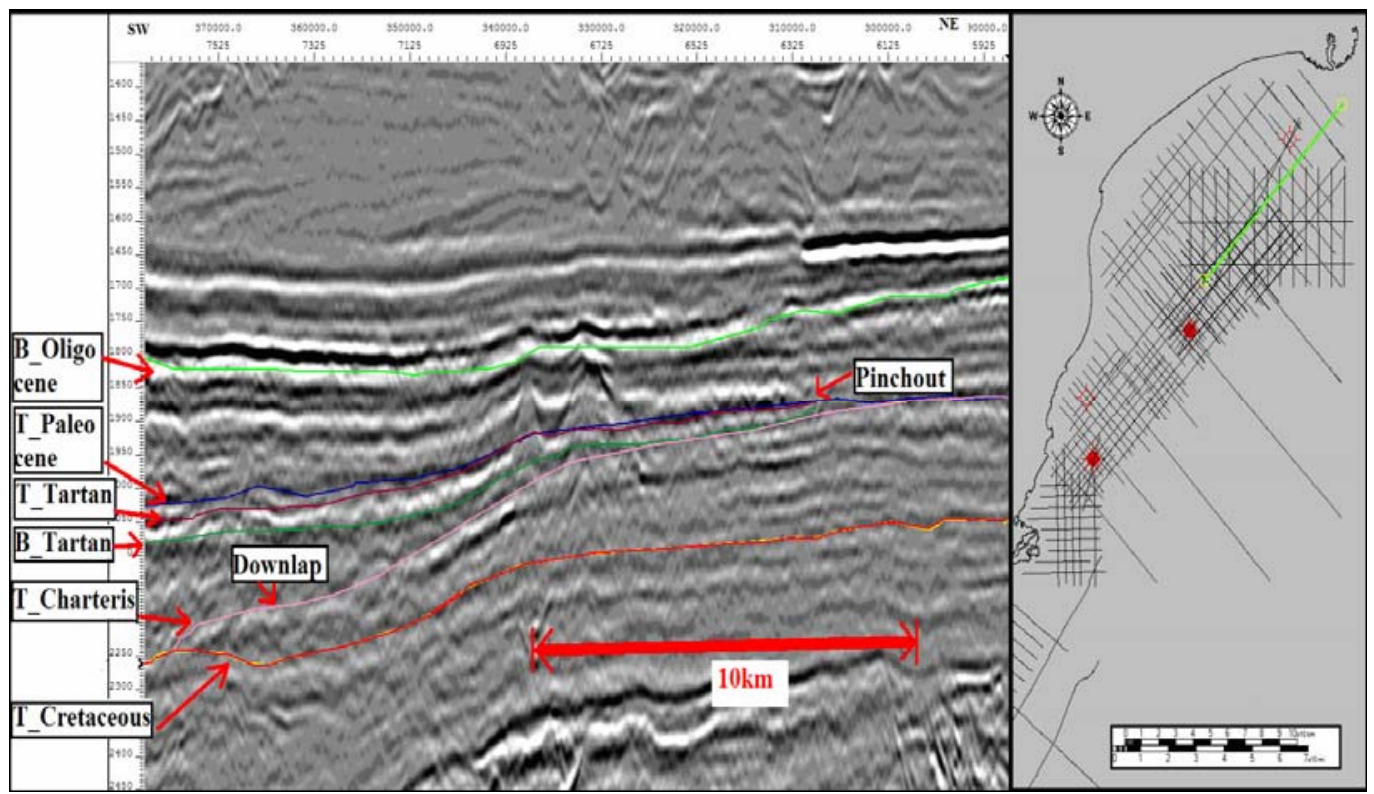

Figure 3.12: Seismic line CB82-25 showing the downlap of the top Charteris Bay Sandstone reflector (pink) onto the top Cretaceous reflector (red). The pinch-out of the Tartan Formation is also observed above the top Charteris Bay Sandstone reflector. 


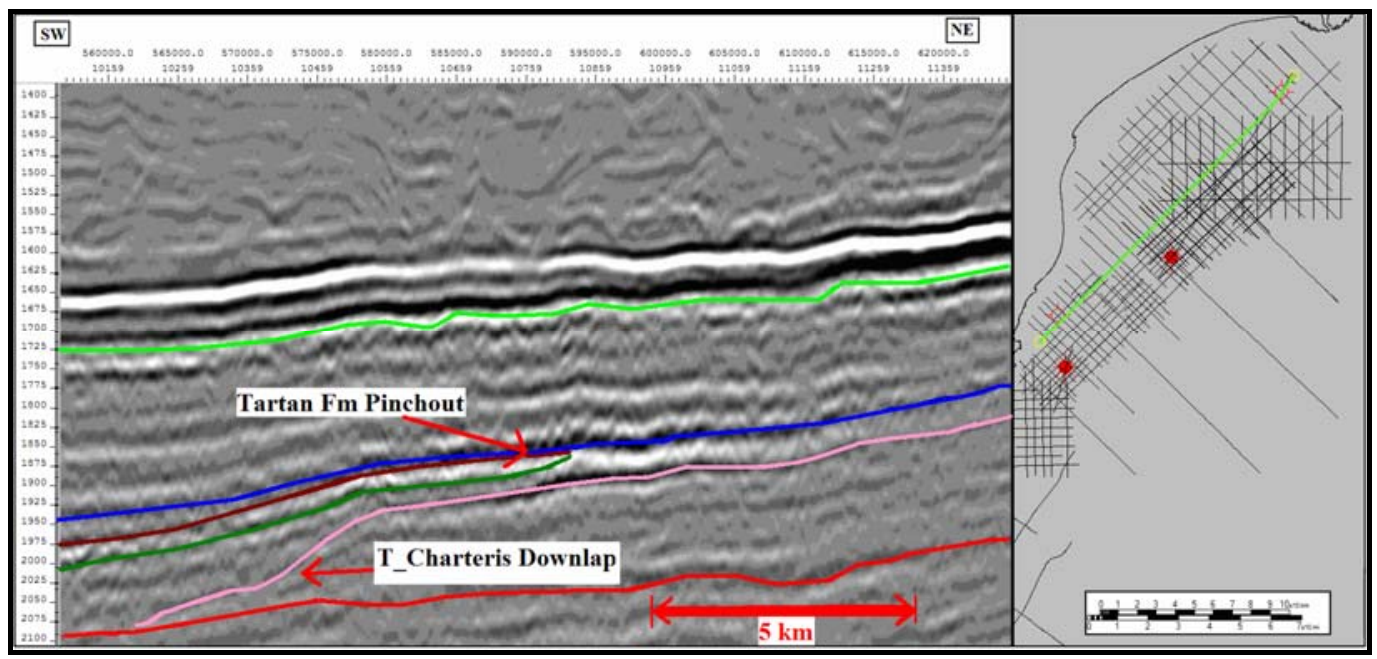

Figure 3.13: Seismic line CB82-19 showing the downlap of the top Charteris Bay Sandstone reflector (pink) onto the top Cretaceous reflector (red). The pinch-out of the Tartan Formation is also observed above the top Charteris Bay Sandstone reflector.

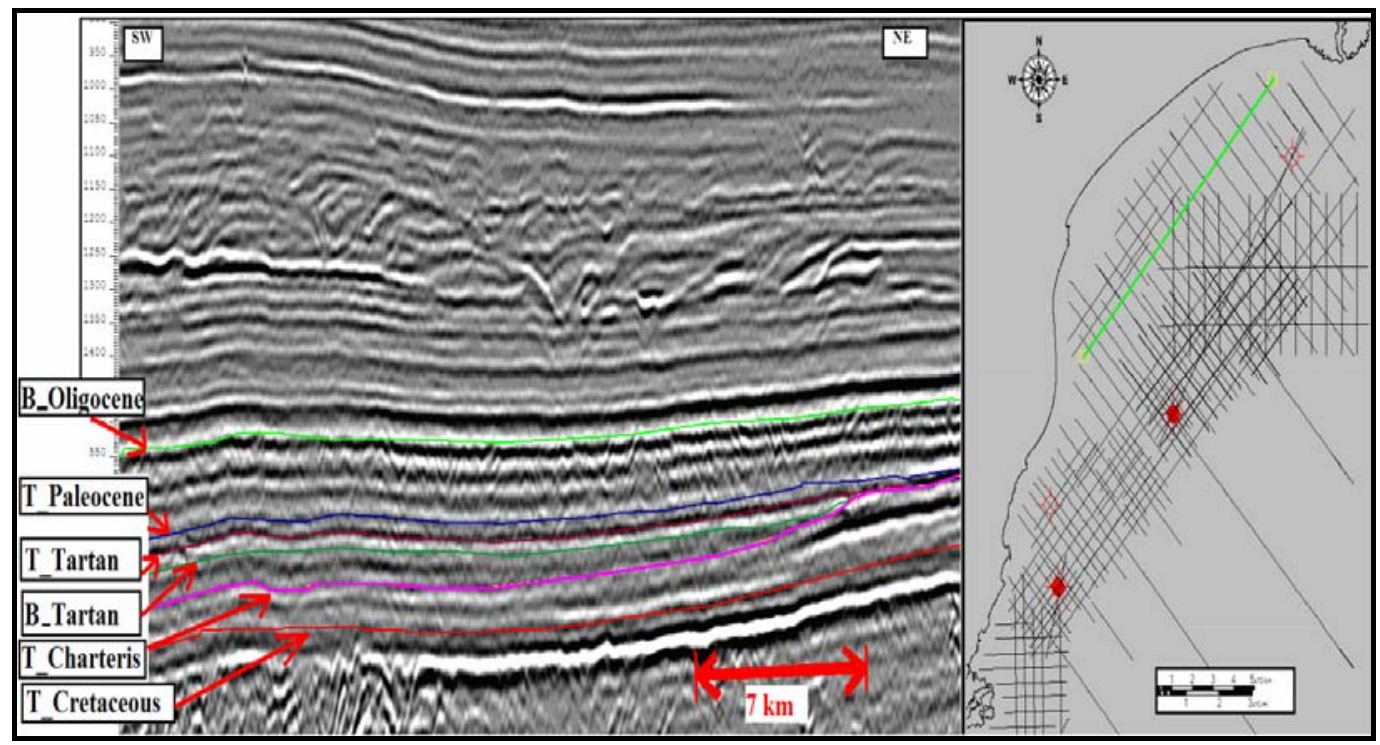

Figure 3.14: Seismic line CB82-11 showing the downlap of the top Charteris Bay Sandstone reflector (pink) onto the top Cretaceous reflector (red). The actual downlap occurs further southwest. The Tartan Formation pinch-out above the top Charteris Bay Sandstone reflector is also interpreted.

\subsection{Seismic Facies of Paleocene-Eocene sediments}

The seismic facies of the Paleocene and Eocene sediments generally show similar characteristics over this time interval. The reflectors within this interval are parallel to subparallel with low amplitudes. They have shallow seaward dips and though examples of onlap are scarce and subtle, they can be seen to occur on lines perpendicular to the coast (Figure 3.15). This is also due to very shallow dipping reflection geometries which make 
reflection terminations very difficult to pick out. Onlap against some of these boundaries could suggest that they are sequence boundaries as described by Vail (1987).

The reflectors are not very continuous across the basin. Amplitudes are gained and lost in certain regions. This is however difficult to correlate but would indicate changing impedance contrasts related to slight changes in lithology and deposition. The thickness of sediments here increases from the coast towards the centre of the basin and decreases towards deep water. Sediments also thin towards the west. The Charteris Bay Sandstone is represented by generally parallel to sub-parallel reflectors which are of low to moderate amplitude. The top of the Charteris Bay Sandstone is marked by a bright reflector caused by the acoustic impedance contrast between the overlying View Hill Volcanics and the Charteris Bay Sandstone below. The Tartan Formation stands out from the other Paleocene reflectors by being of higher amplitude. The amplitude is generally greater towards the centre of the basin and towards the southwest the amplitude is reduced although it is still traceable. It is possible that the changes in amplitude are due to variations in organic content and if so, would suggest that the highest organic richness within the Tartan Formation is present towards the central portion of the offshore Canterbury Basin. The Moeraki Formation identified from core lithofacies descriptions and well correlation (Chapters 4 and 5 respectively) generally possesses internally conformable and parallel to sub-parallel reflectors. However, towards the northeast of the study area, the reflectors are seen to onlap against the Charteris Bay Sandstone and to thin out and disappear, in agreement with well correlation and core lithofacies analysis, which show this formation to be absent at the Resolution-1 well. The Eocene Hampden section is generally composed of parallel to sub-parallel reflectors which vary in amplitude across the basin. 


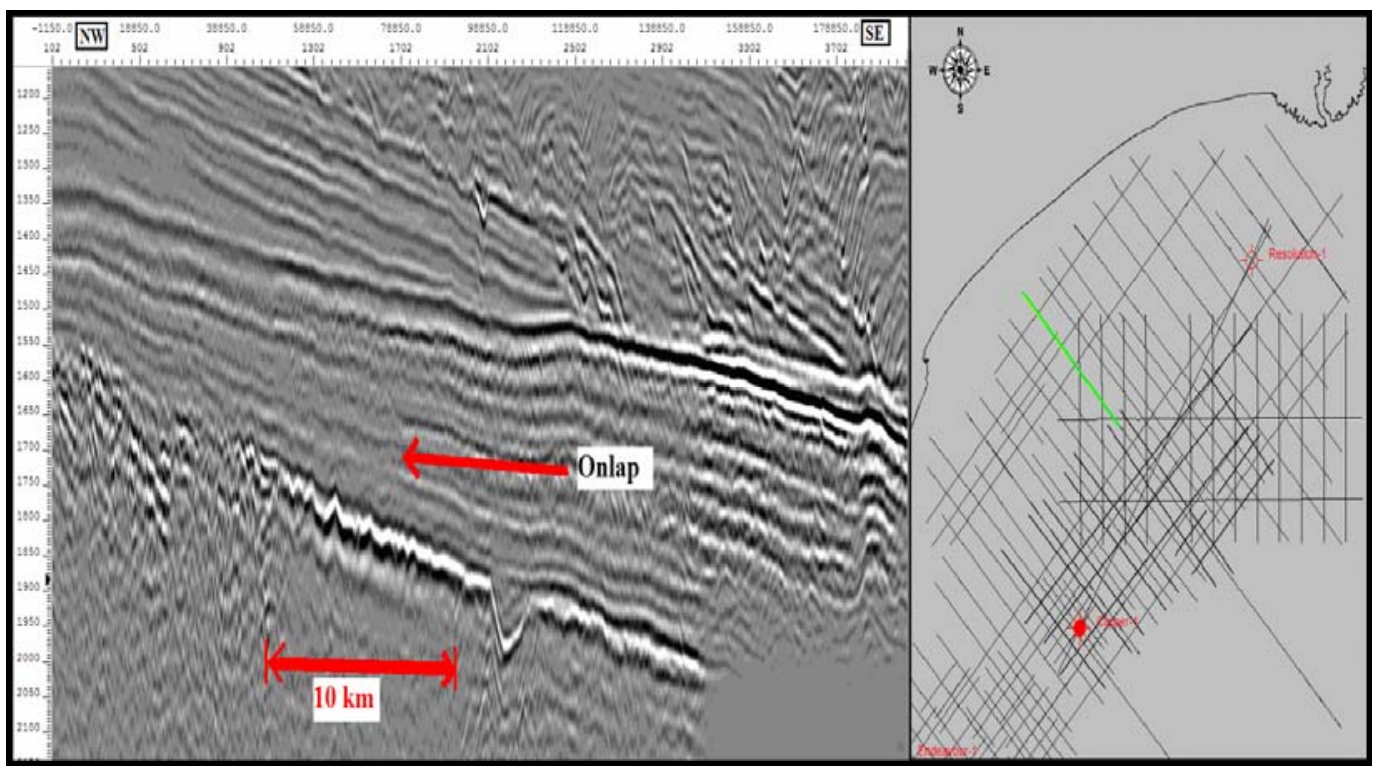

Figure 3.15: Seismic line CB82-30 perpendicular to the coast and showing subtle onlap marked by the red arrow. Note the thinning of sediments towards the coast (left). Location of the line is shown by green line in inset to the right.

\subsection{Structure Maps}

Time structure maps of the interpreted horizons were created to provide insights into the development of the Canterbury Basin through the Paleocene and Eocene. The time structure maps show the current configuration of the basin at the level of the horizons mapped, and due to structural deformation being minimal in the basin from Paleocene times, largely shows the development of the Canterbury Basin through the Paleocene and Eocene. Structural deformation is minimal except locally where volcanoes have intruded through the sedimentary succession. The structure maps also show the shelf-slope break, and this together with corroboration from palaeobathymetric data was used to identify the shelf-slope break interpreted in the paleogeographic maps presented in chapter 6. Twoway travel-time (TWTT) structure maps of interpreted horizons were gridded using a minimum curvature method constrained to a polygon of the study area, with a grid spacing of $1000 \mathrm{~m}$ and smoothed once. Contours were generated with a spacing of 50 milliseconds (ms). These maps are presented from Figure 3.16 to Figure 3.22. Isochore maps were created for the Charteris Bay Sandstone and the Tartan Formation to reveal their thicknesses and variations in their thickness across the study area. The isochore maps were created by calculating TWTT isochrons between the horizons corresponding to the top and base of the respective formation which was then gridded. Gridding of the Tartan Formation 
isochore proved difficult due to the low thickness of this formation which caused slightly thicker areas to appear as bulls eyes on maps. However, the colour range representing the thick and thin parts of the formation was extended, providing a more useful map of the thickness of this formation. Isochore maps of the Charteris Bay Sandstone and the Tartan Formation are presented in Figure 3.23 and Figure 3.24 respectively. The isochore maps provide useful information on the distribution of the Charteris Bay Sandstone and the Tartan Formation and also helped define their extents. This was subsequently used in the creation of the paleogeographic maps presented in chapter 6 .

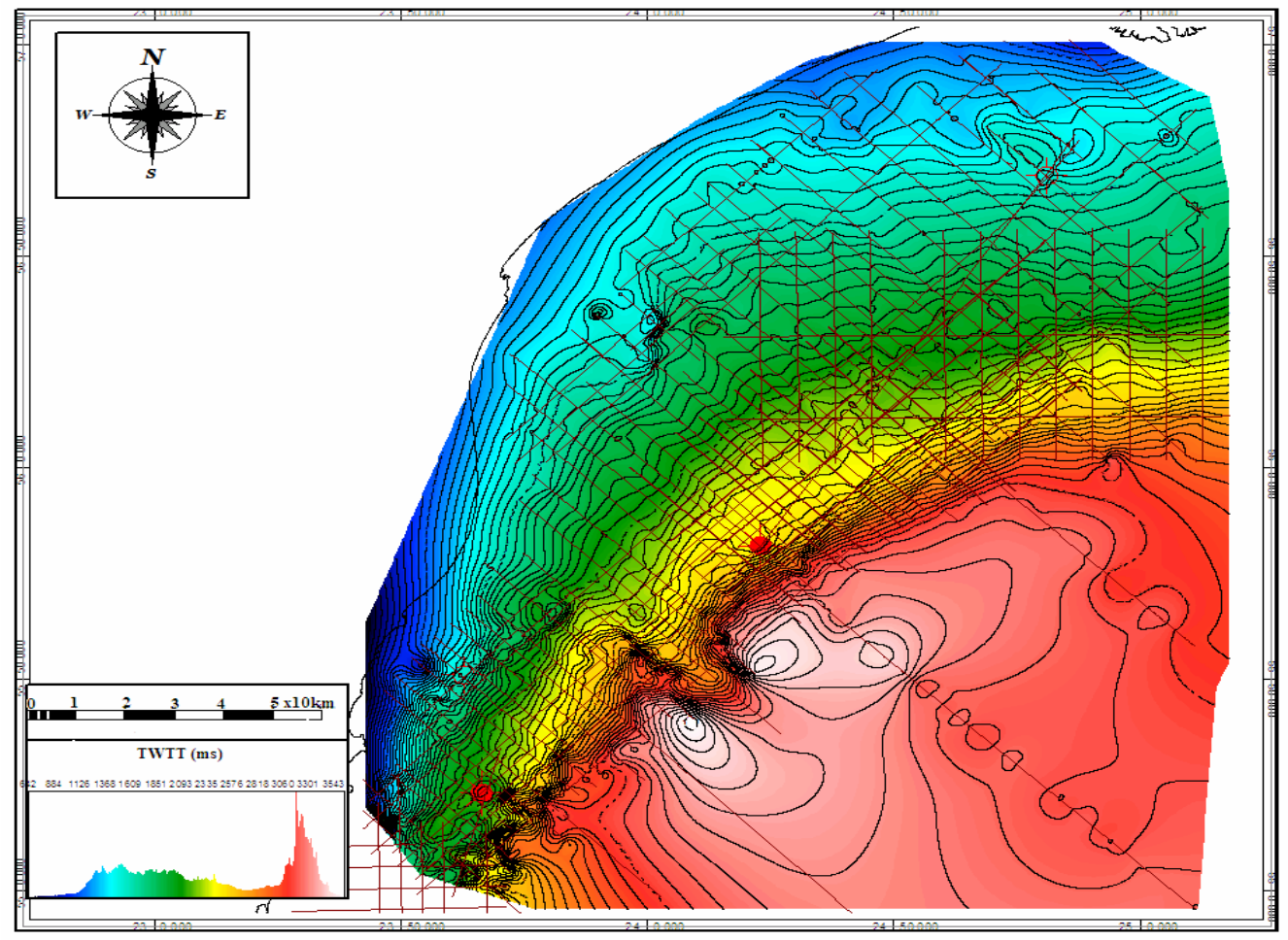

Figure 3.16: Two-way travel-time (TWTT) map in milliseconds of the top Cretaceous horizon mapped over the study area. Red is structurally low $\sim 3000 \mathrm{~ms}$ and blue is structurally high $\sim 600 \mathrm{~ms}$. Visible underneath in dark red are the 2D seismic lines interpreted upon. 


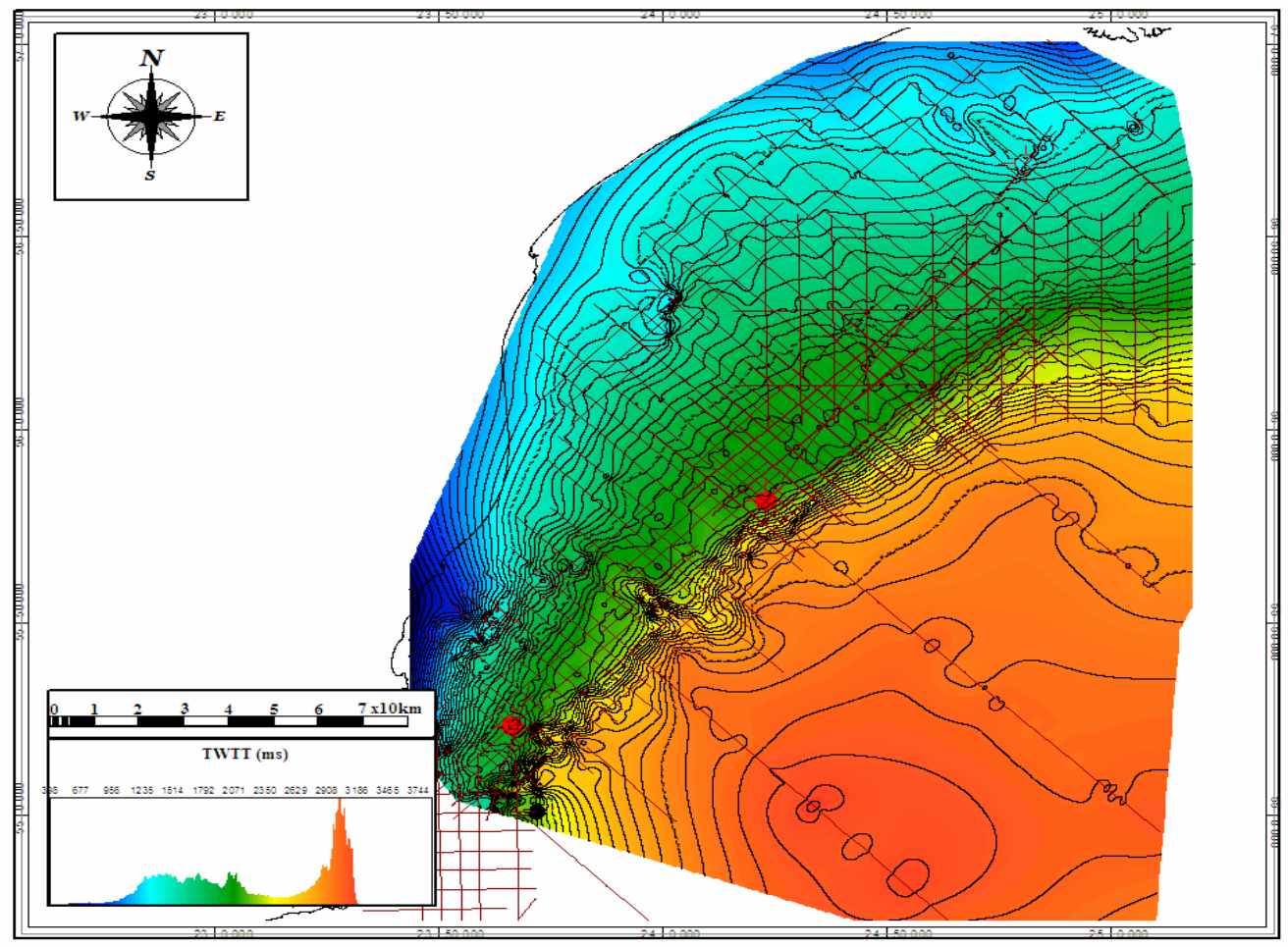

Figure 3.17: Two-way travel-time (TWTT) map in milliseconds of the top Paleocene horizon mapped over the study area. Orange is structurally low $\sim 3000 \mathrm{~ms}$ and blue is structurally high $\sim 500 \mathrm{~ms}$. Visible underneath in dark red are the $2 \mathrm{D}$ seismic lines interpreted upon.

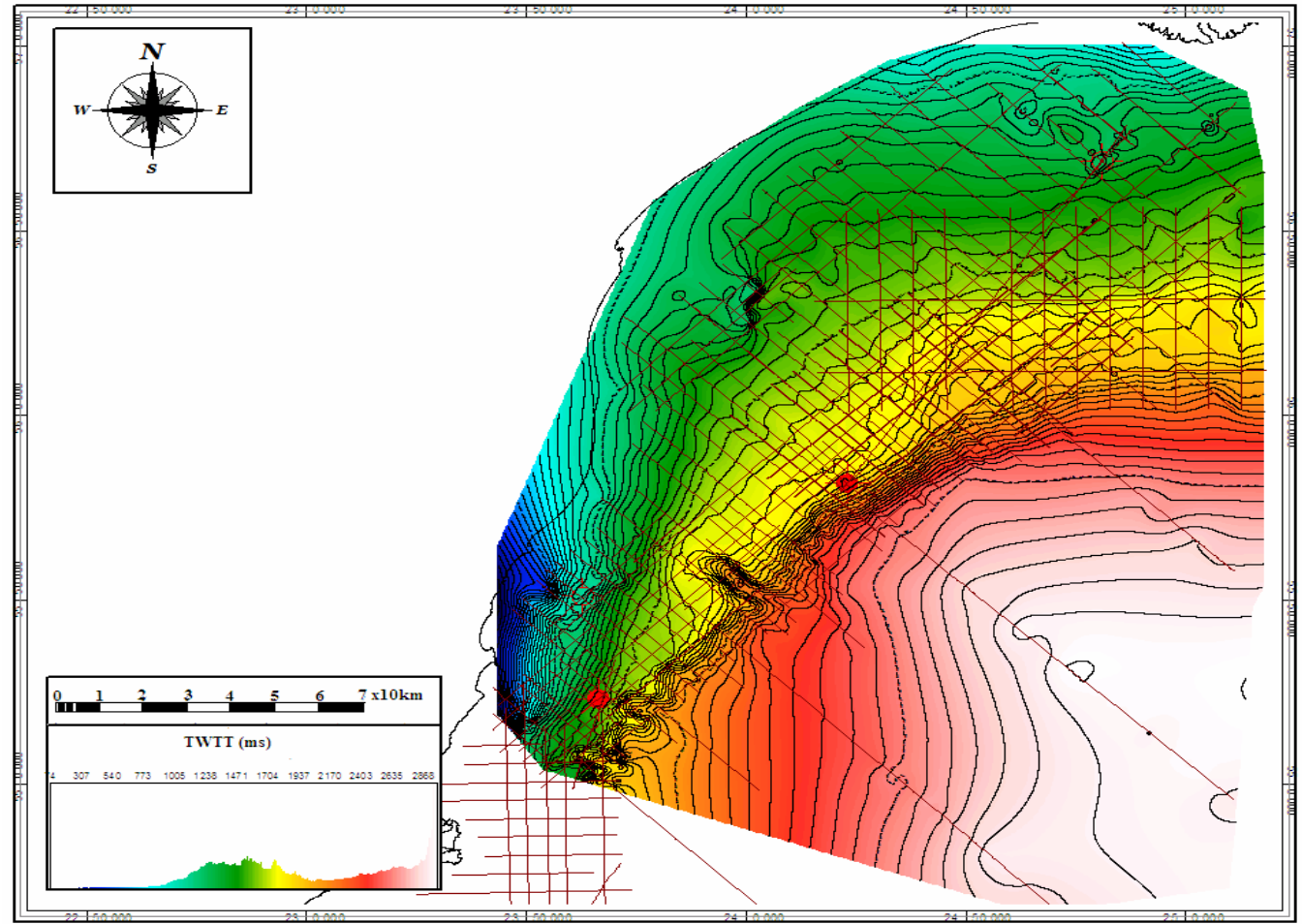

Figure 3.18: Two-way travel-time (TWTT) map in milliseconds of the base Oligocene horizon mapped over the study area. Red is structurally low $\sim 2500 \mathrm{~ms}$ and blue is structurally high $\sim 300 \mathrm{~ms}$. Visible underneath in dark red are the 2D seismic lines interpreted upon. 


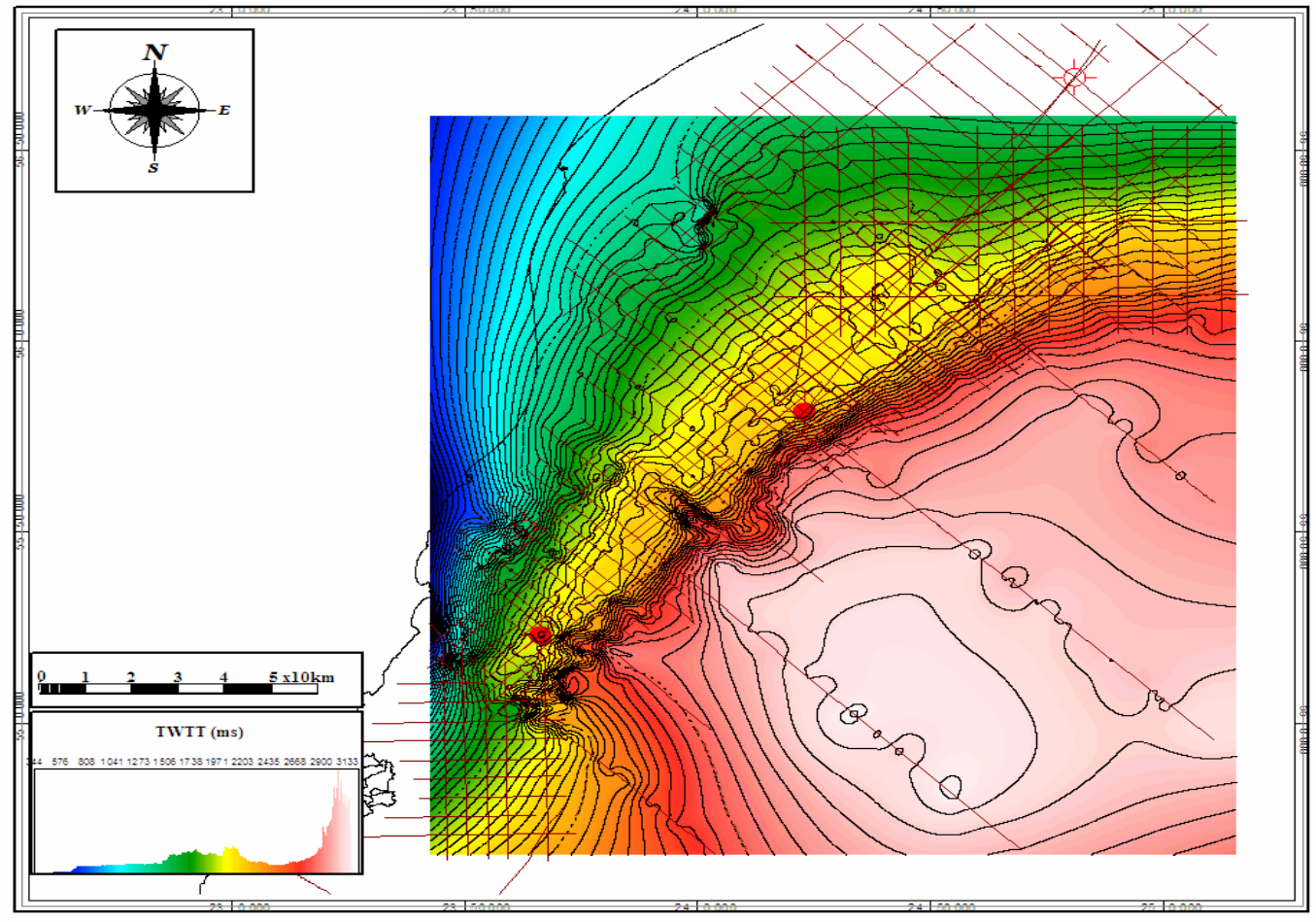

Figure 3.19: Two-way travel-time (TWTT) map in milliseconds of the top of the Tartan Formation mapped over the study area. Red is structurally low $\sim 2800 \mathrm{~ms}$ and blue is structurally high $\sim 700 \mathrm{~ms}$. Visible underneath in dark red are the 2D seismic lines interpreted upon.

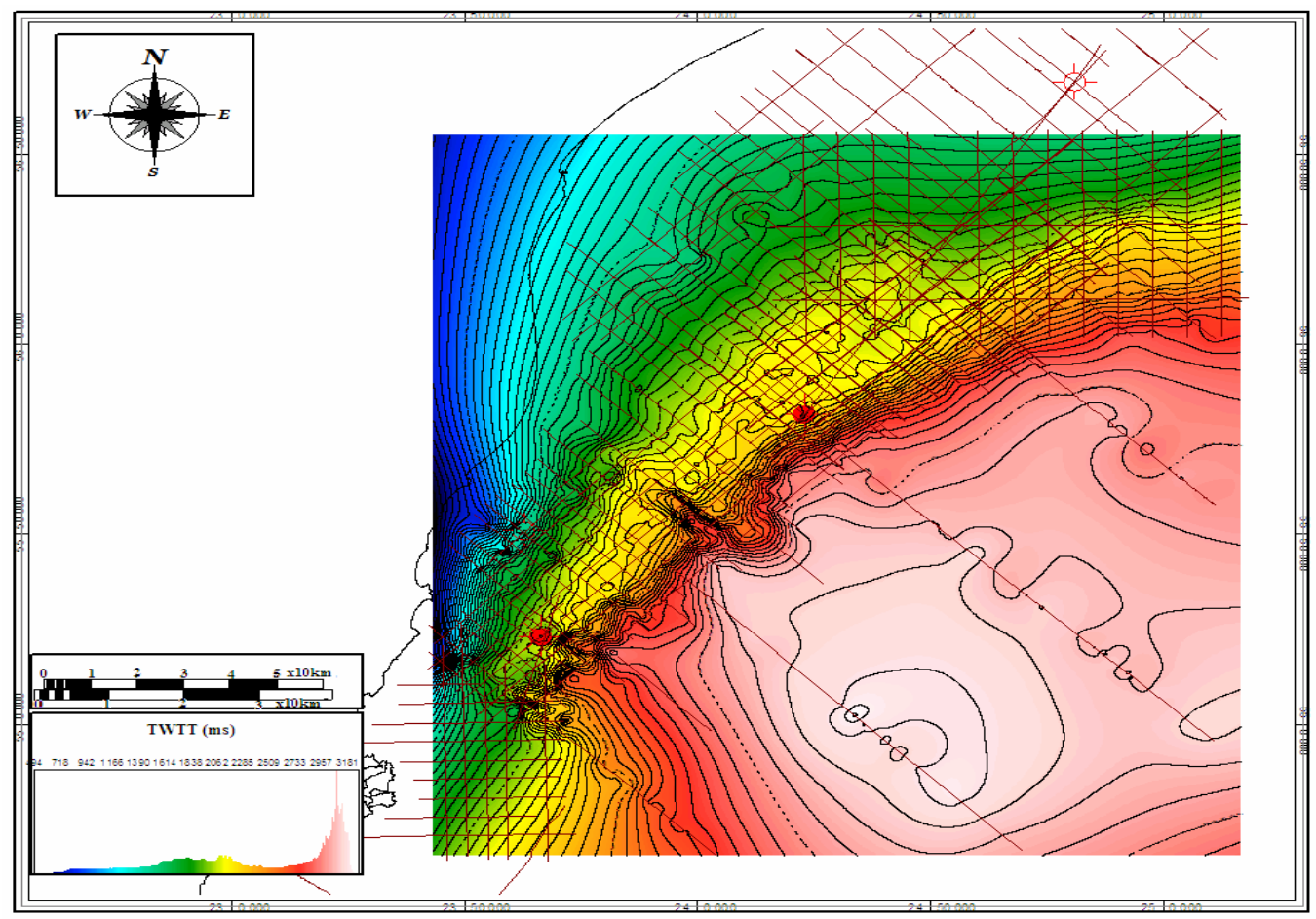

Figure 3.20: Two-way travel-time (TWTT) map in milliseconds of the base of the Tartan Formation horizon mapped over the study area. Red is structurally low $\sim 2850 \mathrm{~ms}$ and blue is structurally high $\sim 750 \mathrm{~ms}$. Visible underneath in dark red are the 2D seismic lines interpreted upon. 


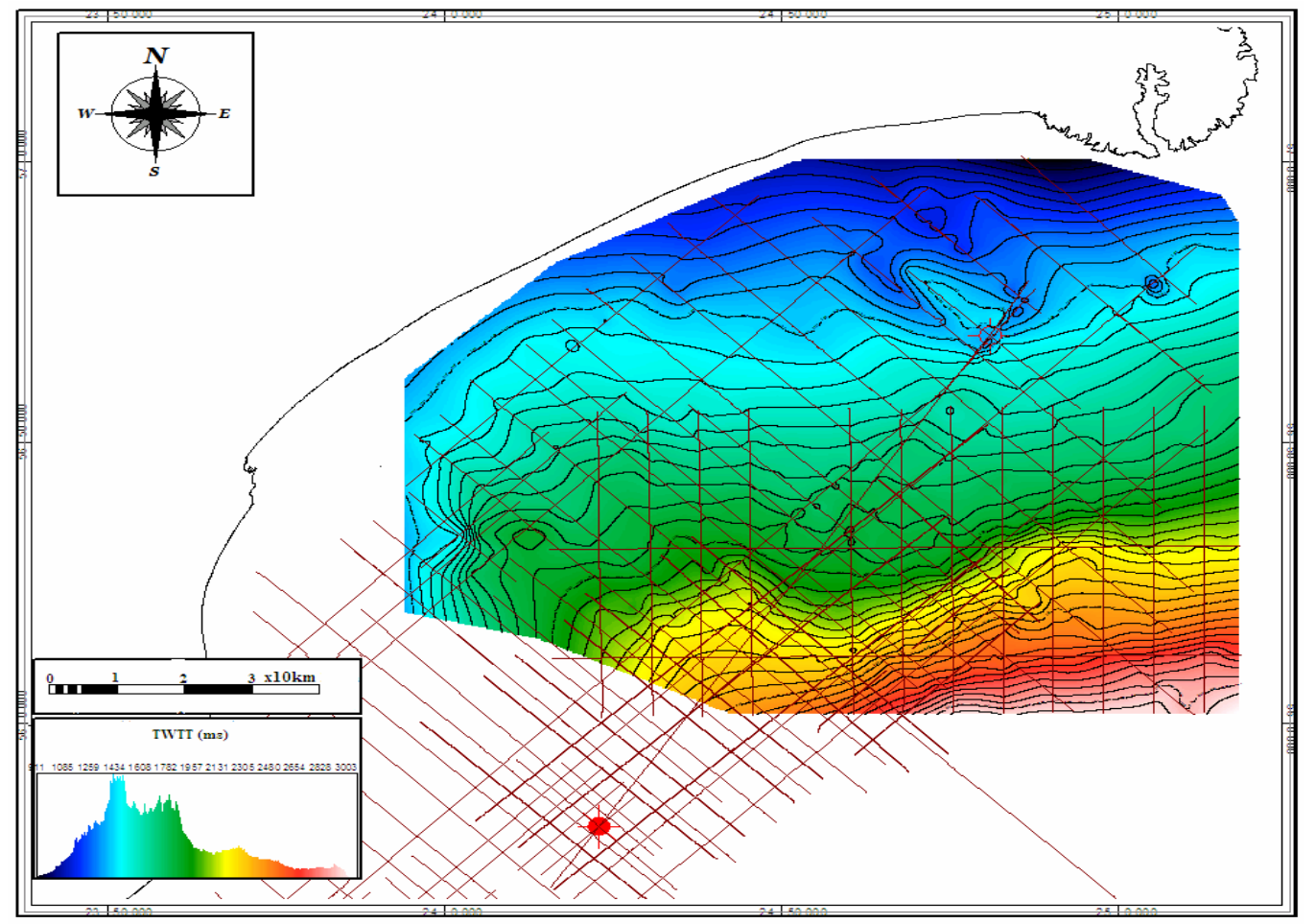

Figure 3.21: Two-way travel-time (TWTT) map in milliseconds of the top Charteris Bay Sandstone horizon mapped over the study area and constrained to a polygon over which it is interpreted to be present. Red is structurally low $\sim 2800 \mathrm{~ms}$ and blue is structurally high $\sim 900 \mathrm{~ms}$. Visible underneath in dark red are the $2 \mathrm{D}$ seismic lines interpreted upon.

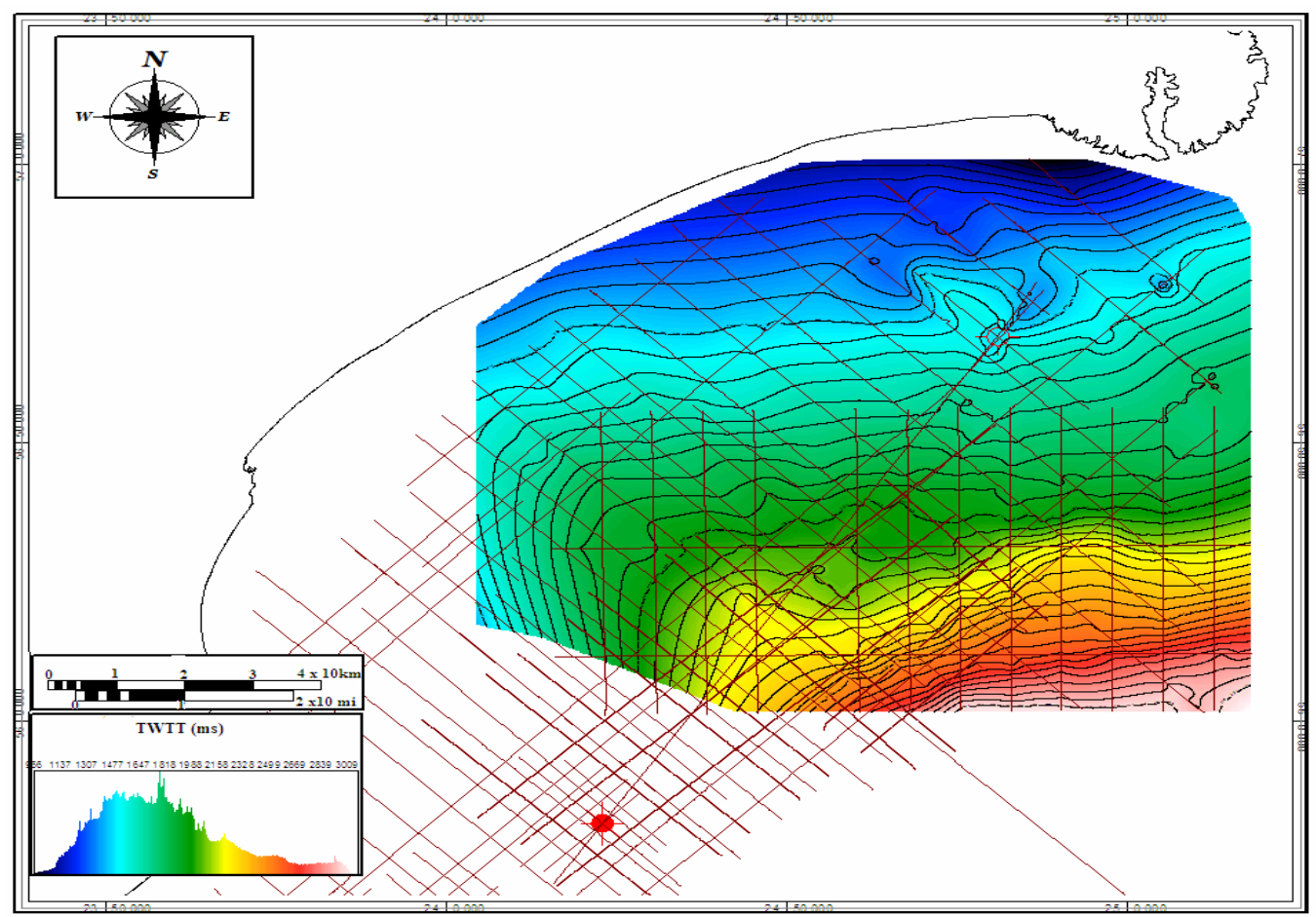

Figure 3.22: Two-way travel-time (TWTT) map in milliseconds of the base of the Charteris Bay Sandstone horizon mapped over the study area. Red is structurally low $\sim 2800 \mathrm{~ms}$ and blue is structurally high $\sim 900 \mathrm{~ms}$. Visible underneath in dark red are the 2D seismic lines interpreted upon. 


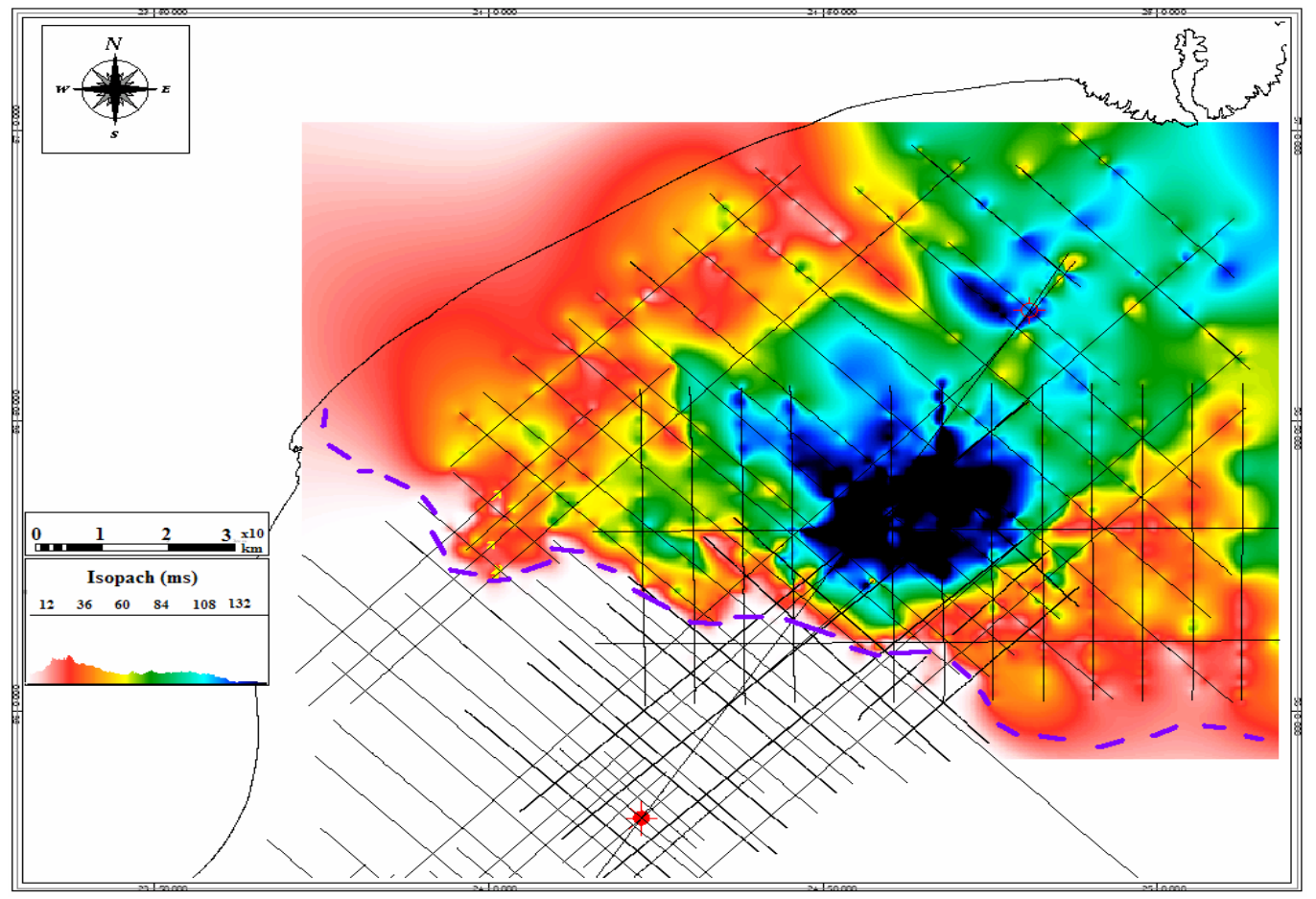

Figure 3.23: TWTT isopach map of the Charteris Bay Sandstone. White is thin $\sim 0 \mathrm{~ms}$ and black is thick $\sim 180 \mathrm{~ms}$. The thickest sandstone package is developed at the centre of the Clipper Sub-basin between Clipper-1 and Resolution-1. Dotted purple line indicates the interpreted wedge out of the Charteris Bay Sandstone used to constrain its southern extent in the paleogeographic map presented in chapter 6. Visible underneath are the 2D seismic lines interpreted upon.

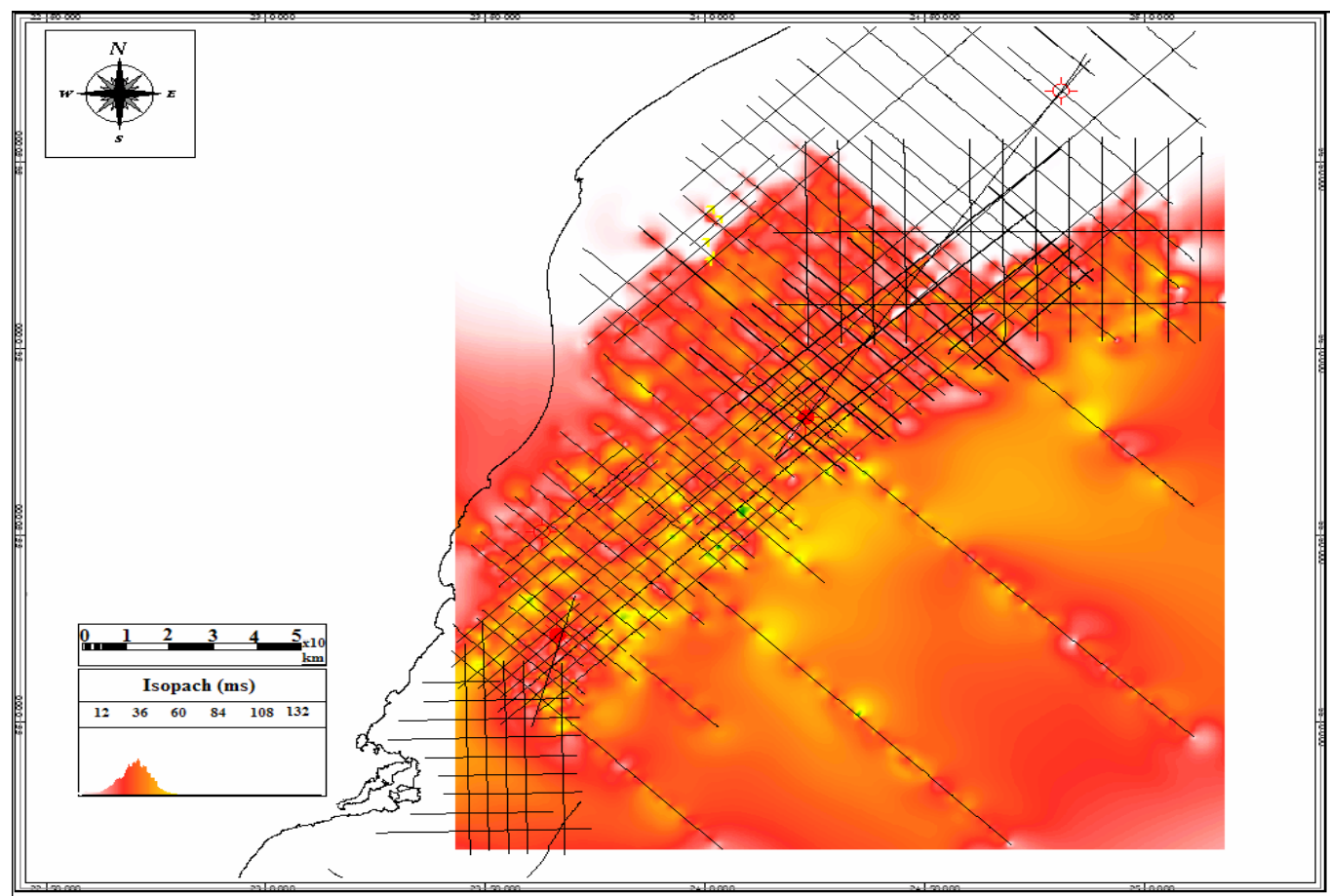

Figure 3.24: TWTT isopach map of the Tartan Formation. White is thin $\sim 0 \mathrm{~ms}$ and yellow is thick $\sim 60 \mathrm{~ms}$. The Tartan Formation is a thin organic rich layer present in the central and southern areas of the study area. Note the northern limit of the formation where it has been interpreted to pinch-out and disappear. 


\subsection{Results and Discussion}

The sedimentary sequence overlying the top Cretaceous to the Oligocene shows very little structural deformation. One large fault is located towards the northwest of Clipper-1 (Figure 3.25). This fault has offset Cretaceous to Recent sediments. A smaller fault is visible next to it having displaced only pre-Eocene sediments. Smaller faults have been mapped around the area of the Resolution-1 well where they appear to have only affected Paleogene sediments (Figure 3.26; Figure 3.27).

The structure maps of the top Cretaceous horizon, top Paleocene horizon and the base Oligocene horizon (Figure 3.16, Figure 3.17 and Figure 3.18 respectively) are very similar as these reflectors are largely parallel to sub-parallel to each other. The sediments overlying the top Cretaceous horizon are characterised seismically by a generally conformable sequence which thins to the north and west, except at the northeast of the study area, towards Resolution-1, where the Moeraki Formation onlaps onto the Charteris Bay Sandstone. At this area of onlap, the Moeraki Formation thins out and is no longer present at the north of the study area, towards Resolution-1. Within the Paleocene sequence is the thin interval of the Tartan Formation. This formation is a bright package on seismic and was intersected by the Galleon-1, Endeavour-1 and Clipper-1 wells (Figure 3.24). Its thickest occurrence within the study area was mapped just southeast of Clipper-1 where it is about 60 milliseconds (ms) thick. Towards the southeast, and into deeper water, the Tartan Formation reflector is still present and is observed to extend out into the deeper parts of the basin, and to generally have high amplitudes. Towards the north, the Tartan Formation has been interpreted to pinch-out (Figure 3.4 D). This pinch-out at the level of this reflector has been observed on other lines as well but the pinch-out is not observed conclusively on all lines as this formation is only one reflector wide. The merging of the top and base of the Tartan Formation is difficult to pick out on some lines due to poor seismic quality, and subtle loss of amplitude. However, the northern to north-eastern limit of the Tartan Formation from seismic mapping has been determined and this is seen in Figure 3.24.

The Charteris Bay Sandstone Isochore map shows the Two-Way Travel-Time (TWTT) thickness of the Charteris Bay Sandstone interpreted within the study area (Figure 3.23). 
The Charteris Bay Sandstone is mapped towards the north of the study area and is present around the local area of the Resolution-1 well. The thickest occurrence is just southwest of the Resolution-1 well where it thickens to about 180ms. The Charteris Bay Sandstone thins towards the northwest, although north and north-westward of Resolution-1 it is seen to be relatively thick. A thick section of the Charteris Bay Sandstone ( $\sim 450 \mathrm{~m}$ thick) is present at Broken River, which is presently inland and northwest of Resolution-1 (Field and Browne 1989a). The zone of transition from the Charteris Bay Sandstone southward to the adjacent mudstones of the Moeraki Formation and its equivalents has been interpreted on seismic and this interpretation agrees with the core information from wells. The Charteris Bay Sandstone was encountered in the Resolution-1 well where the sandstones had excellent measured porosities. However within the study area no closure is seen above the Charteris Bay Sandstone to trap hydrocarbons.

The base Oligocene reflector is erosional in places. Evidence for angular erosional truncation at this level is seen on a few seismic lines especially on ones southeast of Clipper-1 (Figure 3.28; Figure 3.29; Figure 3.30). The erosion appears to have taken place in deep water, and supports the hypothesis of sea bottom erosion due to current activity as suggested by Carter (1985). Sediments encountered at the four open-file offshore wells above and below this unconformity were all deposited in at least outer neritic environments as indicated by the microfaunal assemblages. In order for this erosion to have been subaerial, massive amounts of uplift and/ or sea level fall would have had to have taken place, evidence for which is absent, and this further supports the erosion as having taken place in deep water. The Oligocene unconformity has been previously called the Marshall paraconformity and so far evidence for angular erosion has been very rare (Lewis, 1992). However, some lines within the study area show evidence for non-regional, localised angular truncation below the base Oligocene reflector (Figure 3.28 to Figure 3.30). The angular truncation however only appears to be at the local area and away from here sediments once again appear conformable. The erosional feature persists northwards on lines down dip of Clipper-1 and only disappears towards Resolution-1. This erosional record would suggest strong sea bottom currents operating at this time. 


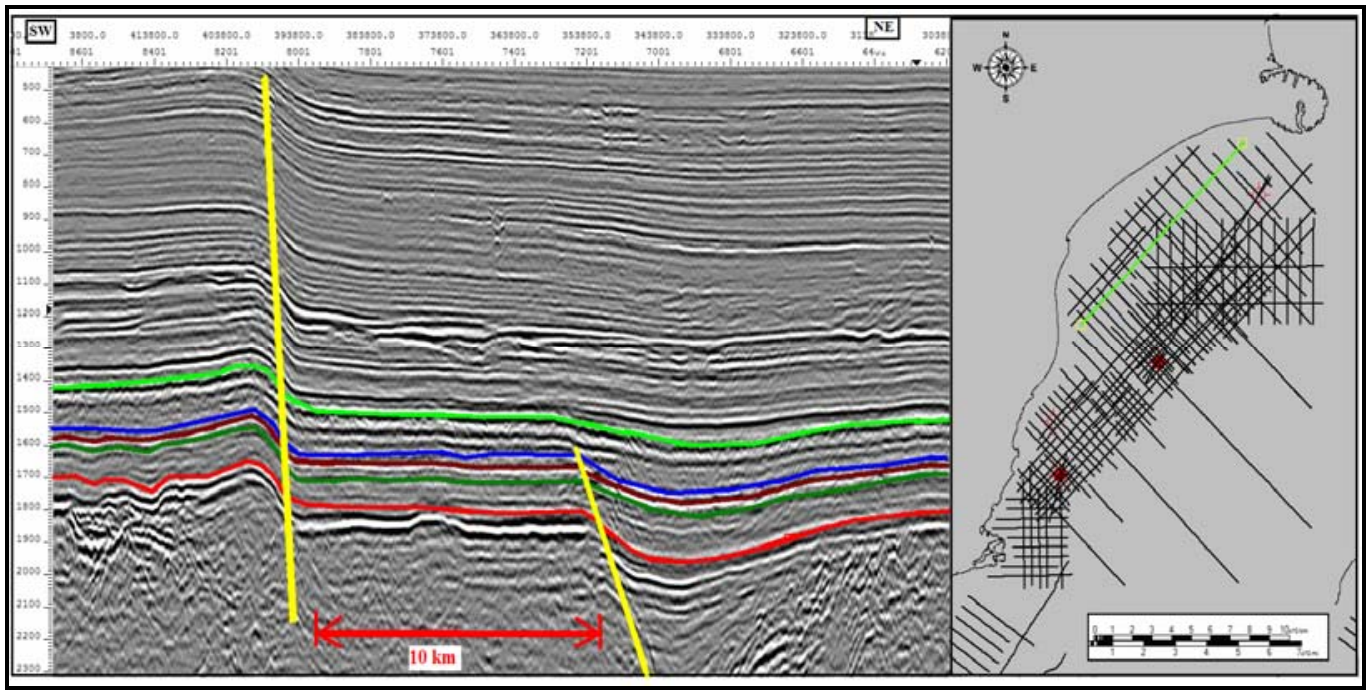

Figure 3.25: Seismic line CB82-11 showing large normal fault at the northwest of the study area. Note the huge thickness of sediments affected. Also visible to the right is a smaller fault affecting only pre-Eocene sediments. Location of line is shown in green on seismic grid to the right.

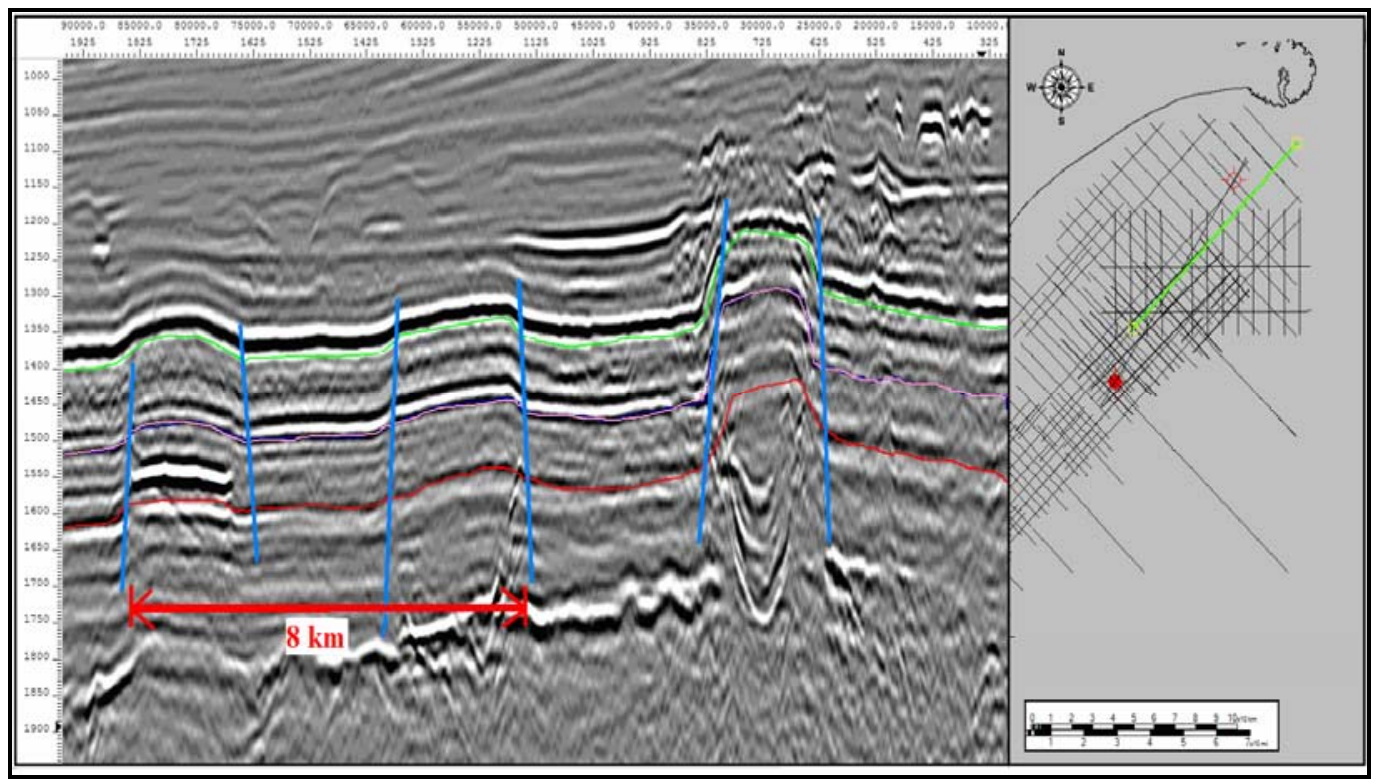

Figure 3.26: Seismic line CB82-25 showing small normal faults close to the Resolution-1 well. These smaller normal faults have been mapped around the local area of the Resolution-1 well. However, due to their small size it has not been possible to correlate them between seismic lines. Location of line is shown in green on seismic grid to the right. 


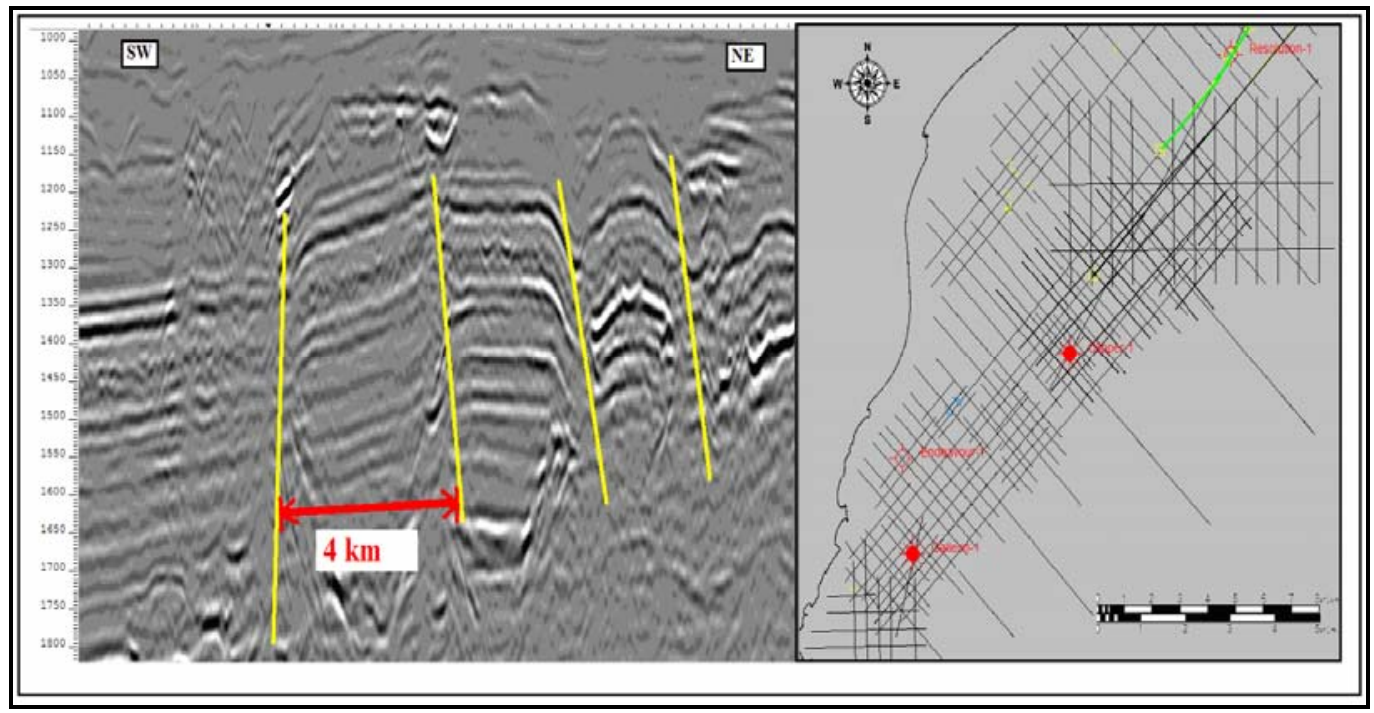

Figure 3.27: Seismic line CB82-19 showing four faults very close to the Resolution-1 well. Location of line is shown in green on seismic grid to the right.

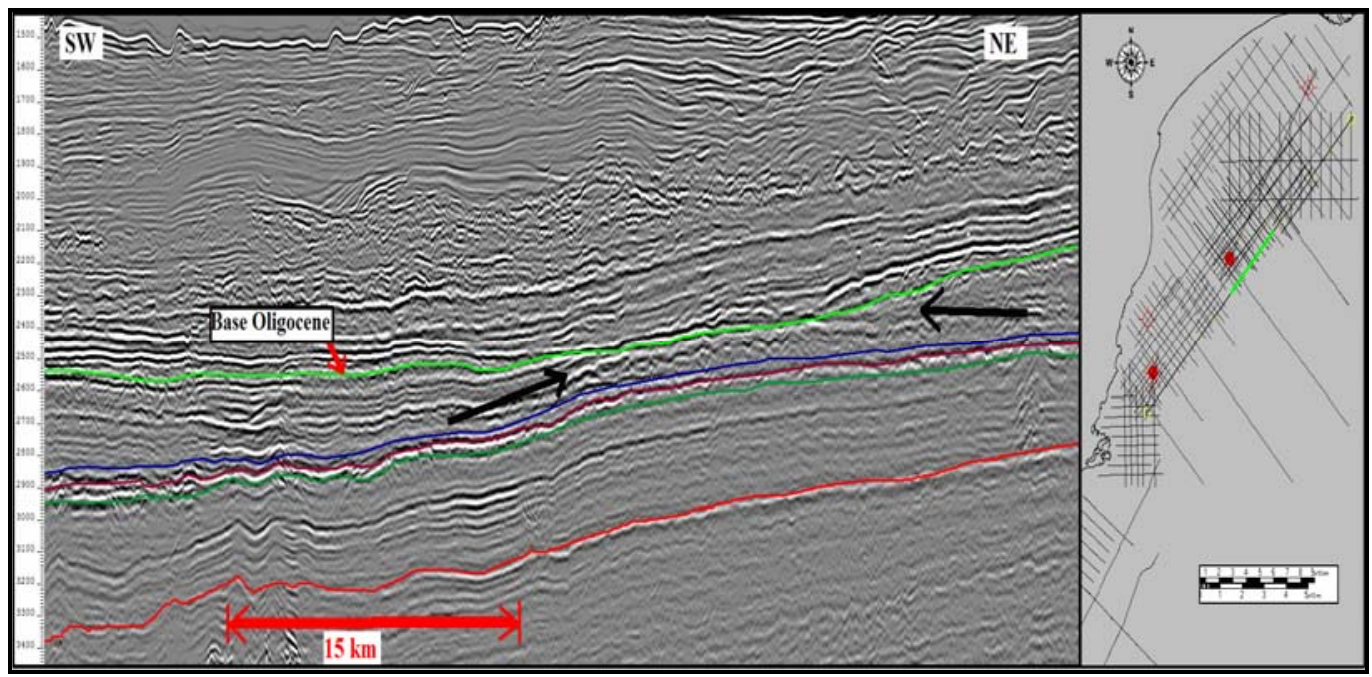

Figure 3.28: Seismic line CB82-47b showing erosional truncation below base Oligocene reflector truncating Eocene sediments. Black arrows point to areas of truncation. Location of line is shown in green on seismic grid to the right. 


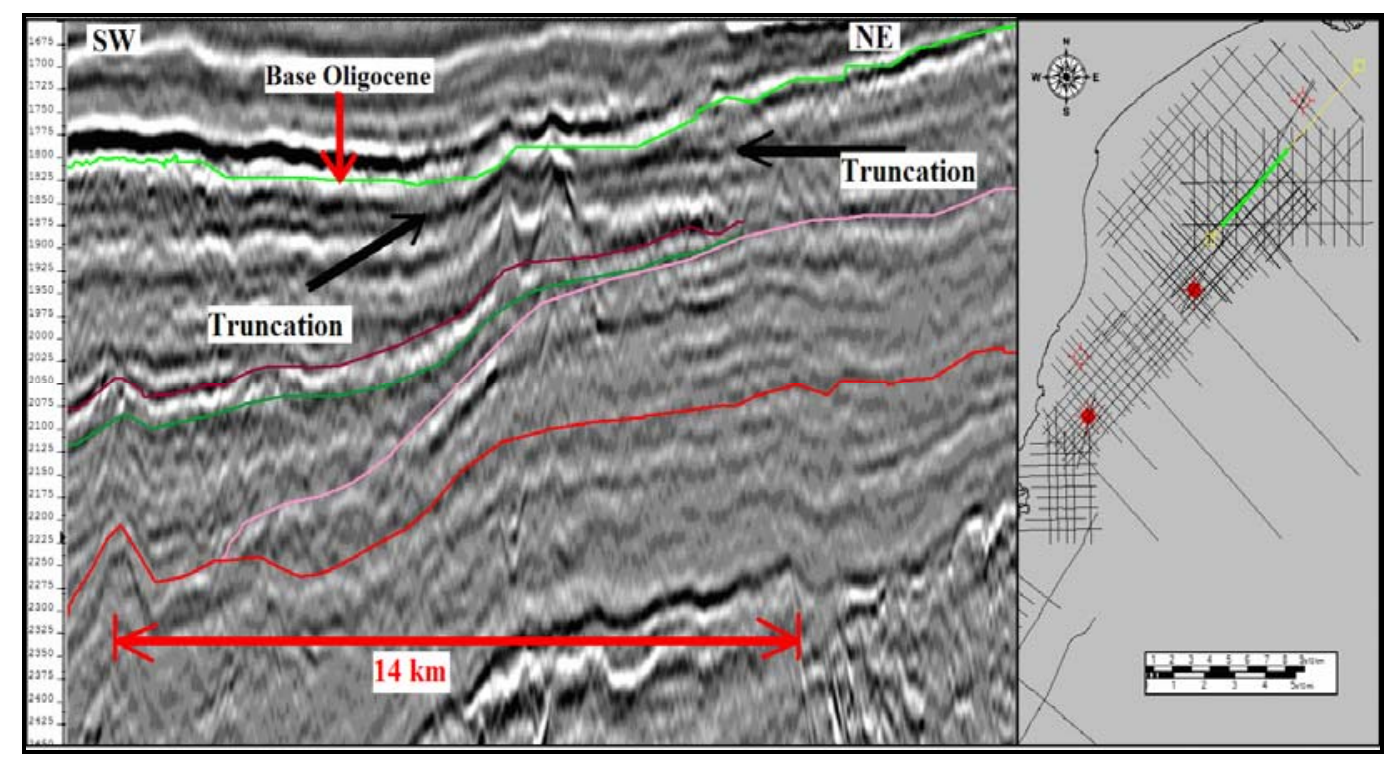

Figure 3.29: Seismic line CB82-25 showing angular truncation of Eocene sediments below the base Oligocene horizon. Black arrows point to areas of truncation. Location of line is shown in green on seismic grid to the right.

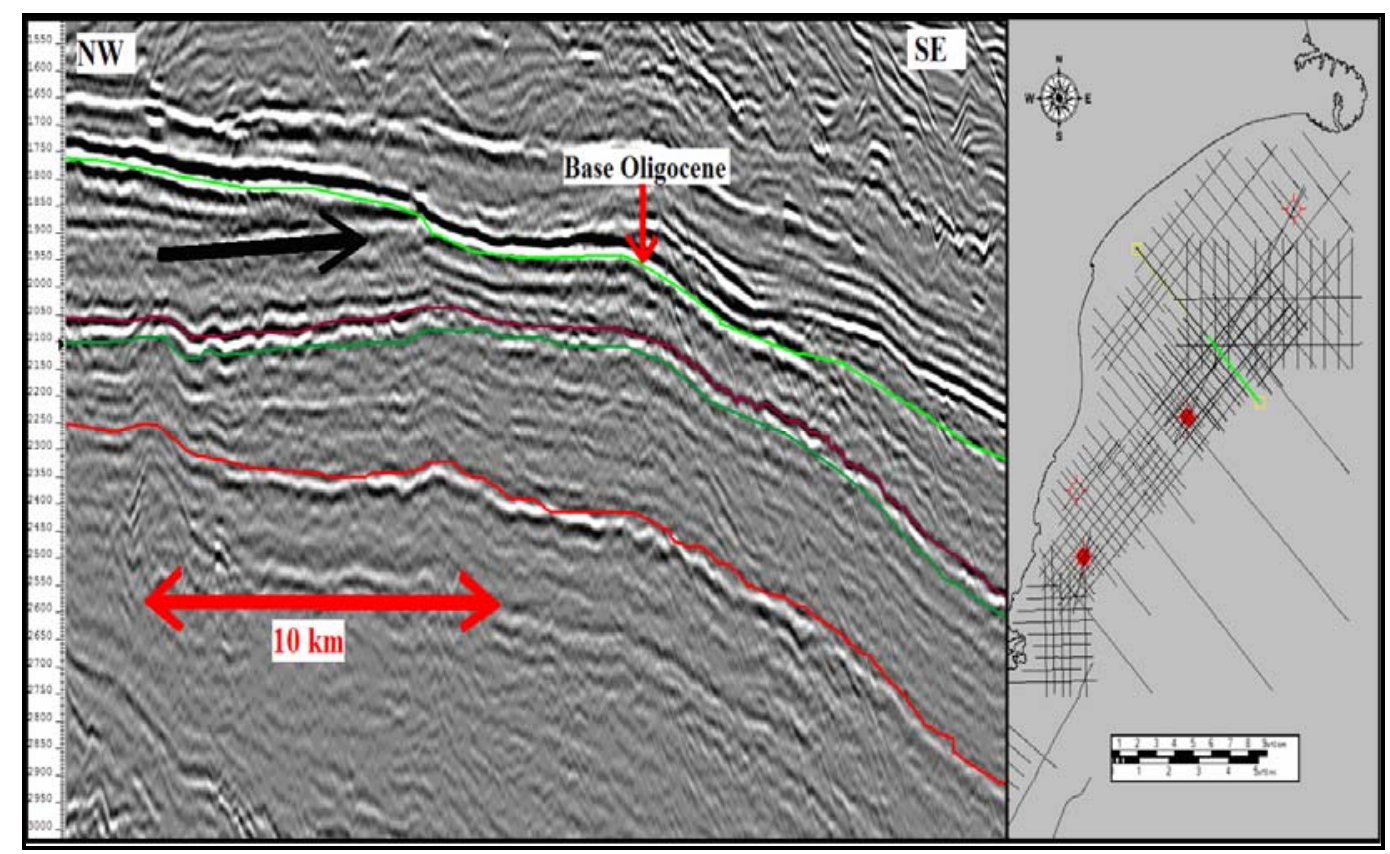

Figure 3.30: Angular truncation seen along a dip line on seismic line CB82-36. Note the amount of Eocene sediments seen to be eroded here. Black arrow points to area of truncation. Location of line is shown in green on seismic grid to the right. 


\subsection{Summary}

The stratigraphic and spatial extents of the Paleogene sediments were defined by seismic correlation and mapping. The extent of the Tartan Formation was mapped out and shows that this formation is distinct from the enclosing Moeraki Formation and is present in the central and southwest regions and thins out towards the northwest (Resolution-1). The extent of the Charteris Bay Sandstone was mapped out within the study area and the downlap surface of the Charteris Bay Sandstone onto the top Cretaceous reflector was mapped. Seismic facies within this interval are fairly uniform and consistent with no marked change in depositional conditions. Subtle onlap at this level indicates a sea level rise through this interval, possibly punctuated by small scale regressive events (Chapter 6), although evidence for this is not readily evident on seismic. An unconformity associated with the base Oligocene horizon has been mapped and in certain places seems to have locally eroded substantial thicknesses of Eocene sediments. 


\subsection{Core and Cuttings Facies}

\subsection{Introduction}

In the offshore Canterbury Basin, there have been five wells drilled so far of which information for four is open-file: Galleon-1, Endeavour-1, Clipper-1 and Resolution-1. These four wells lie within the study area. Sidewall cores from these petroleum exploration wells provide a physical sample of the drilled rock and hence a direct representation of the subsurface. This allows the sediments penetrated to be described in detail and developed into a simple lithofacies scheme which can assist in interpreting depositional environments. This can then be compared with seismic and wireline logs to provide more information on overall depositional history of the Paleocene interval in the basin.

The first well to be drilled in the offshore Canterbury Basin was Endeavour-1, in 1970, to test a closure adjacent to the coast, and reached a total depth of $2741 \mathrm{~m}$ bdf (below derrick floor). Within this well there were two intervals that were fully cored; $1926 \mathrm{~m}-1930 \mathrm{~m}$ and $2738 \mathrm{~m}-2741 \mathrm{~m}$. The first cored interval lies in the Paleocene interval but unfortunately was not present at the Core Store. The second cored interval is well below the base of the Paleocene. The rest of the drill hole was sampled by sidewall cores. In 1974, Resolution-1 was drilled to test for hydrocarbons in Early Tertiary to Late Cretaceous sandstones in an anticlinal feature and reached a total depth of $1963 \mathrm{~m}$ brt (below rotary table). A single interval from 1958m-1969m was conventionally cored and sidewall cores were obtained from $1221.5 \mathrm{~m}-1908.5 \mathrm{~m}$. The whole core obtained from this well was well below the base of the Paleocene and was not examined. Clipper-1 was the next well to be drilled in the region, in 1984, to test potential Cretaceous reservoirs within a structural closure. Total depth reached was $4742 \mathrm{~m}$ brt. Two conventional cores were obtained; from 4265.04273.1m and from 4309-4315.2m brt. Both these intervals are well below the Paleocene interval. However, sidewall cores were obtained from to $780 \mathrm{~m}-4720 \mathrm{~m}$ which included the Paleocene interval. The next well drilled was Galleon-1, in 1985, to test for hydrocarbons within Late Cretaceous Coal Measure Sandstones. Total depth reached was 3086m brt. Two whole cores were recovered from the intervals $2752.6 \mathrm{~m}-2771.5 \mathrm{~m}$ and from $2771.5 \mathrm{~m}-$ $2789.9 \mathrm{~m}$. Both these cored intervals are in the Cretaceous interval. Sidewall cores were obtained from $1638.5 \mathrm{~m}-3055 \mathrm{~m}$ which represents the Miocene to Cretaceous interval. 
Due to the expense and time involved in coring coupled with sparse sandstone distribution in the Paleocene interval of the Canterbury Basin, there is only one full core available (from Clipper-1) and relatively few sidewall cores. Nevertheless, sidewall cores representative of each formation within the Paleocene to Eocene interval from three of the wells drilled in offshore Canterbury Basin were selected, described and photographed at the Crown Minerals Core Store (Table 4.1). These were from Resolution-1, Clipper-1 and Galleon-1 which provided a wide geographic coverage of the Basin (Appendix F). The samples were observed dry and under natural light. Unfortunately, some side wall cores and whole core for Clipper-1 were missing from the collection. This was unfortunate as Clipper-1 penetrated the thickest Paleogene succession of all the four wells in the study area. Despite the limited dataset, lithological descriptions together with photographs of the cores identified several typical facies. These observations provide the basis for constructing a simple lithofacies scheme for the rocks deposited during the Paleocene in the Canterbury Basin. Combined with previous descriptions, fossil content, wireline log signatures and seismic expression, an interpretation of depositional environment can be made. 


\begin{tabular}{|c|c|c|}
\hline Galleon-1 (m brt) & Endeavour-1 (ft bdf) & Resolution-1 (m bkb) \\
\hline 2163 & 5230 & 1462 \\
\hline 2197.6 & 5300 & 1474 \\
\hline 2259.1 & 5370 & 1478 \\
\hline 2320.8 & 5410 & 1480 \\
\hline 2381 & 5500 & 1510 \\
\hline 2396.3 & 5640 & 1525 \\
\hline 2402 & 5690 & 1528 \\
\hline 2502 & 5700 & 1532 \\
\hline 2506.5 & 5750 & 1534 \\
\hline 2512.4 & 5800 & 1546 \\
\hline 2519.5 & 5860 & 1557 \\
\hline 2533.5 & 5900 & 1560 \\
\hline 2559.2 & 6100 & 1562 \\
\hline 2595 & 6245 & 1566 \\
\hline 2629.7 & 6330 & 1567.5 \\
\hline \multirow[t]{10}{*}{2690.2} & 6510 & 1572 \\
\hline & & 1574.4 \\
\hline & & 1579 \\
\hline & & 1581 \\
\hline & & 1590 \\
\hline & & 1610 \\
\hline & & 1640 \\
\hline & & 1668 \\
\hline & & 1685 \\
\hline & & 1740 \\
\hline
\end{tabular}

Table 4.1: List of Sidewall Core samples (SWC) along with their depths looked at in this study. All depths are in Along Hole Below Drilling Floor (AHBDF). For Galleon-1 and Resolution-1, depths are in meters while for Endeavour-1 depths are in feet according to the sidewall core depths from well completion reports and their labelling in core. 


\subsection{Lithofacies}

Five lithofacies were identified from analysis of the sedimentological descriptions and photographs from sidewall cores. These comprise three mudstone facies (Mudstone 1, 2 and 3), two sandstone facies and a volcanic facies. The characteristics of the facies and broad interpretation are summarised in Table 4.2.

\begin{tabular}{|c|c|c|c|}
\hline Facies & Code & Description & Interpretation \\
\hline Mudstone 1 & MST & $\begin{array}{l}\text { Light to medium dark grey } \\
\text { mudstone, massive, homogenous, } \\
\text { with occasional glauconite grains } \\
\text { and occasional pyrite flakes. }\end{array}$ & $\begin{array}{l}\text { Low energy inner shelf to } \\
\text { outer shelf deposition of } \\
\text { mudstones. }\end{array}$ \\
\hline Mudstone 2 & $\operatorname{MST}(\mathrm{m})$ & $\begin{array}{l}\text { Medium to dark grey mudstone, } \\
\text { fissile to subfissile, micaceous, } \\
\text { firm to hard }\end{array}$ & $\begin{array}{l}\text { Low energy, mid shelf } \\
\text { deposition of mudstones. }\end{array}$ \\
\hline Mudstone 3 & $\operatorname{MST}(\mathrm{o})$ & $\begin{array}{l}\text { Dark brown grey mudstone, } \\
\text { organic rich, slight oily odour. }\end{array}$ & $\begin{array}{l}\text { Low energy, marginal } \\
\text { marine to mid shelf } \\
\text { deposition of organic rich } \\
\text { mudstones. }\end{array}$ \\
\hline Sandstone 1 & SST 1 & $\begin{array}{l}\text { Very light white brown to light } \\
\text { brown very fine to fine sandstone, } \\
\text { friable, moderately well sorted }\end{array}$ & $\begin{array}{l}\text { Low to high energy, } \\
\text { marginal marine to mid } \\
\text { shelf deposition of clean } \\
\text { sands }\end{array}$ \\
\hline Sandstone 2 & SST 2 & $\begin{array}{l}\text { Blue grey sandstone, extremely } \\
\text { hard and cemented with quartz } \\
\text { veins and glauconite. }\end{array}$ & $\begin{array}{l}\text { Higher energy deposition } \\
\text { and shallow water } \\
\text { environment. }\end{array}$ \\
\hline Volcanics & VOL & $\begin{array}{l}\text { Dark green basalt, abundant steam } \\
\text { cavities, and occasional xenoliths } \\
\text { of muddy siltstone. }\end{array}$ & $\begin{array}{l}\text { Basaltic volcanism in } \\
\text { non-marine and marine } \\
\text { environment. }\end{array}$ \\
\hline
\end{tabular}

Table 4.2: Summary of core lithofacies based on sedimentological descriptions and photographs of sidewall core samples of the Paleocene and Eocene intervals within Galleon-1, Endeavour-1 and Resolution-1.

\subsubsection{Mudstone 1}

Mudstone 1 facies are light to medium dark grey mudstones. They are calcareous, firm and homogenous and contain occasional glauconite grains (Figure 4.1). All cores classified as 
Mudstone 1 facies were from strata in the drillcores previously described as the Hampden Formation (Eocene). One sample at Endeavour-1 $(1615.44 \mathrm{~m})$ contained a pyrite nodule and few mica flakes and another $(1594 \mathrm{~m})$ contained isolated organic material, 1-4 mm long (Figure 4.2). These two samples at Endeavour-1 have been grouped together with the Mudstone-1 facies as there are insufficient samples or lithological variation for a new facies group.

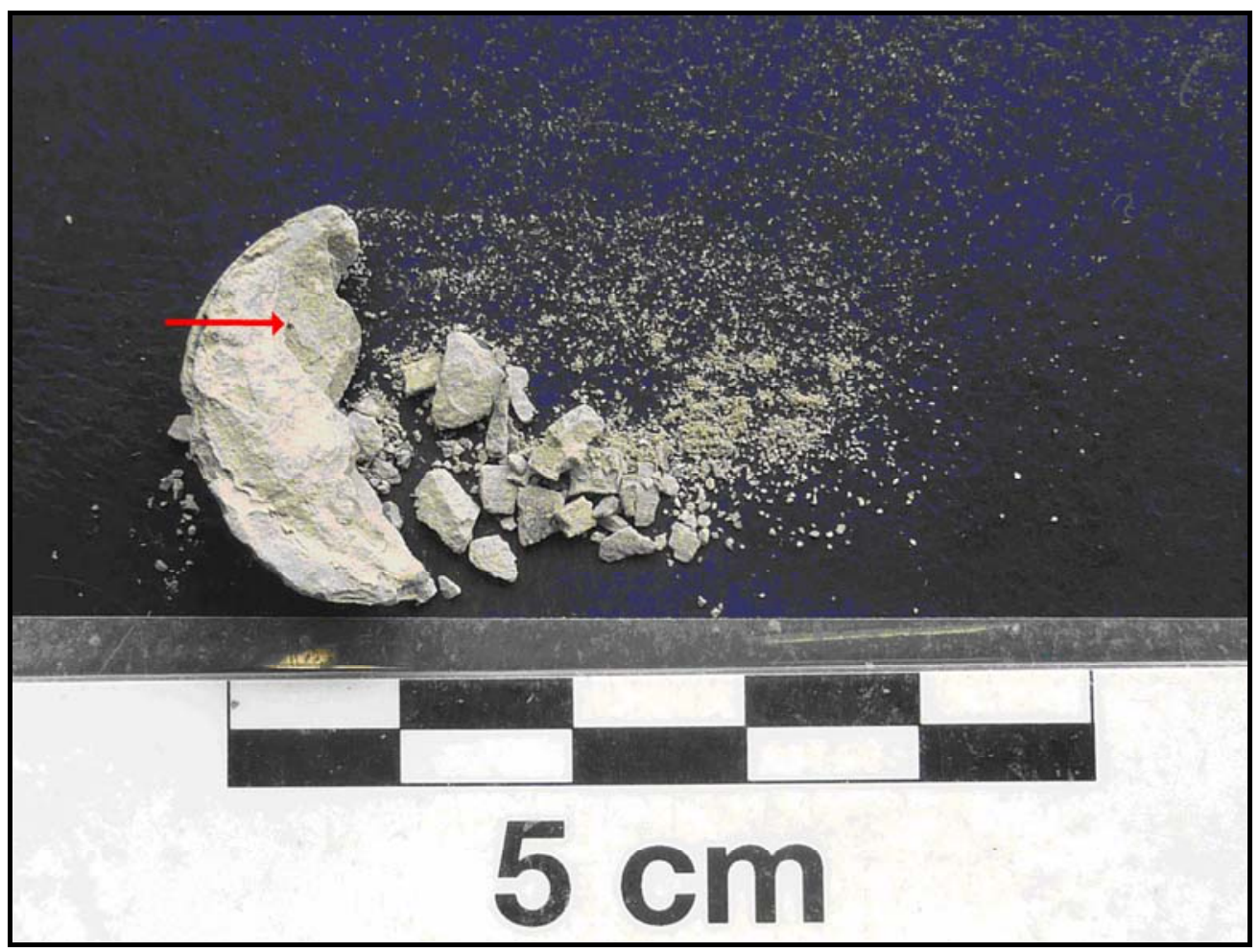

Figure 4.1: Representative sidewall core sample of Mudstone 1 facies from Galleon-1 at 2163m brt. Red arrow points to a glauconite pellet. All Mudstone 1 facies are from the Eocene Hampden Formation. 


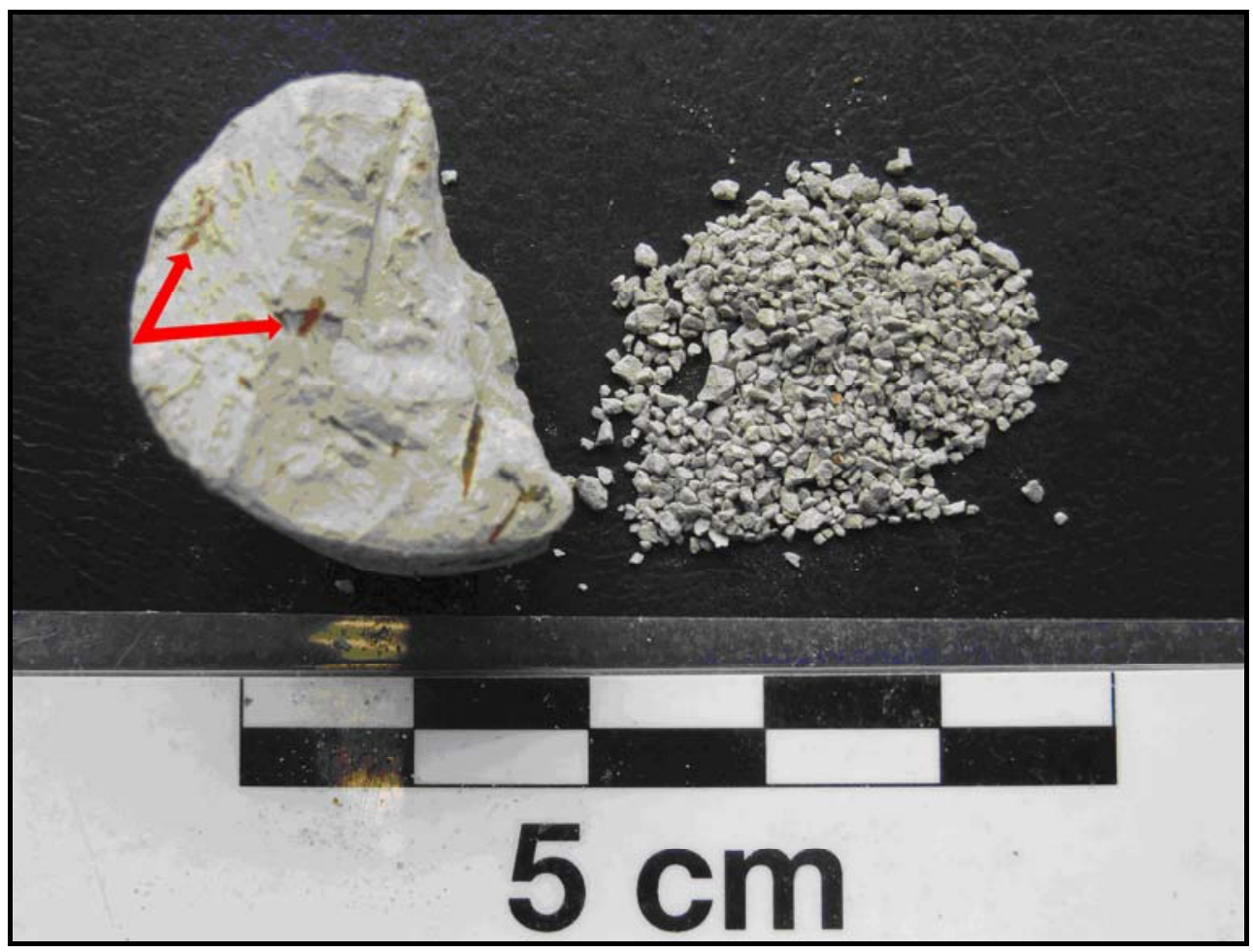

Figure 4.2: Mudstone 1 sidewall core sample from $1594 \mathrm{~m}$ brt (below rotary table) at Endeavour-1. Arrows point to organic fragments.

\subsubsection{Mudstone 2}

The Mudstone 2 facies are medium-dark grey mudstone, fissile to subfissile, micaceous, and firm to hard (Figure 4.3). All cores classified as Mudstone 2 facies were from strata in the drillcores previously described as the Moeraki Formation. 


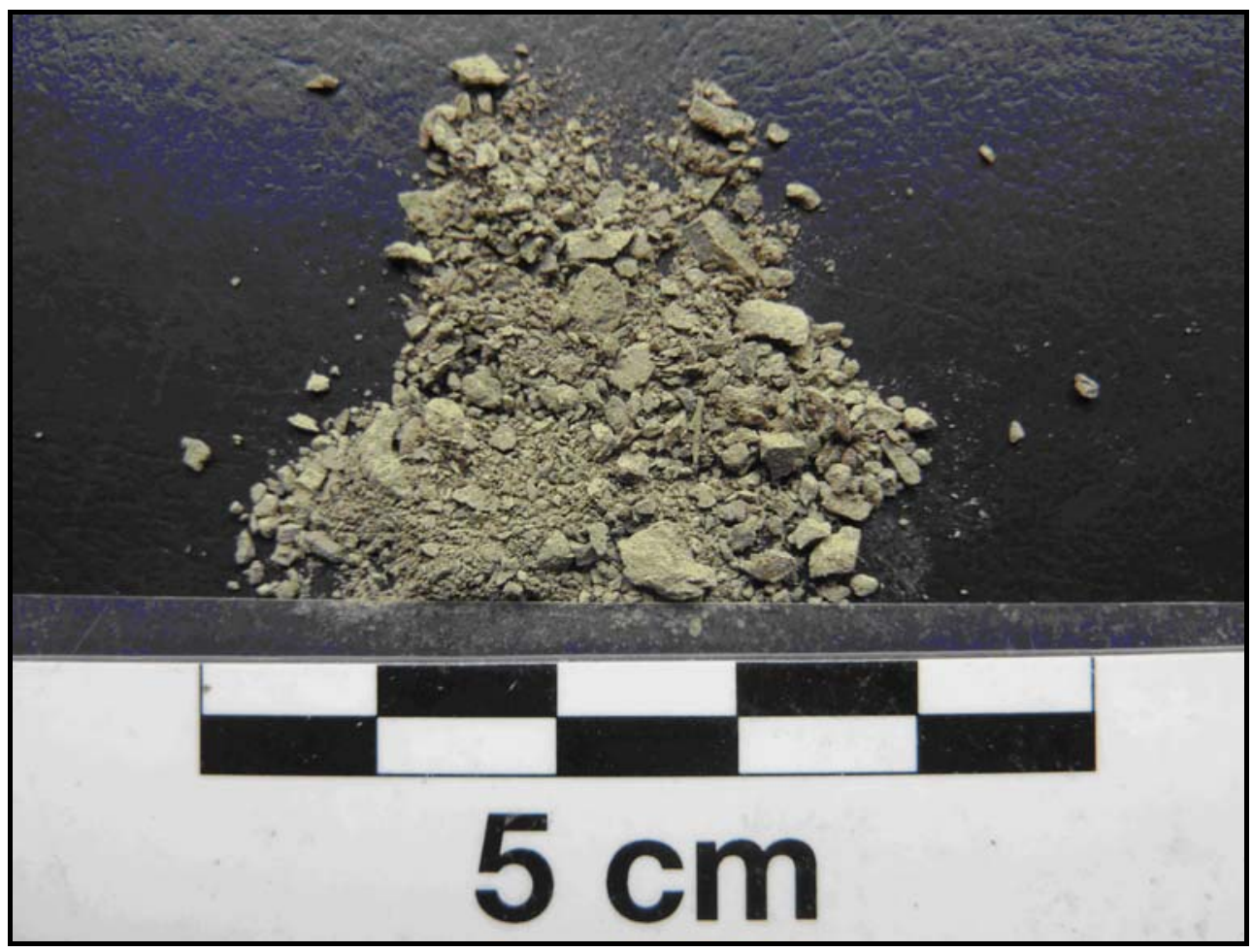

Figure 4.3: Example of Mudstone 2 facies from sidewall core sample from $2559.2 \mathrm{~m}$ brt at Galleon-1 and representative of the Moeraki Formation.

\subsubsection{Mudstone 3}

This facies consists of dark brown to grey, organic rich mudstone with a few samples giving a slight oily odour (Figure 4.4). Examples of this distinctive facies are inferred to be from the Tartan Formation which is present within lighter coloured mudstones of the Moeraki Formation and indicates a marked change in depositional conditions. 


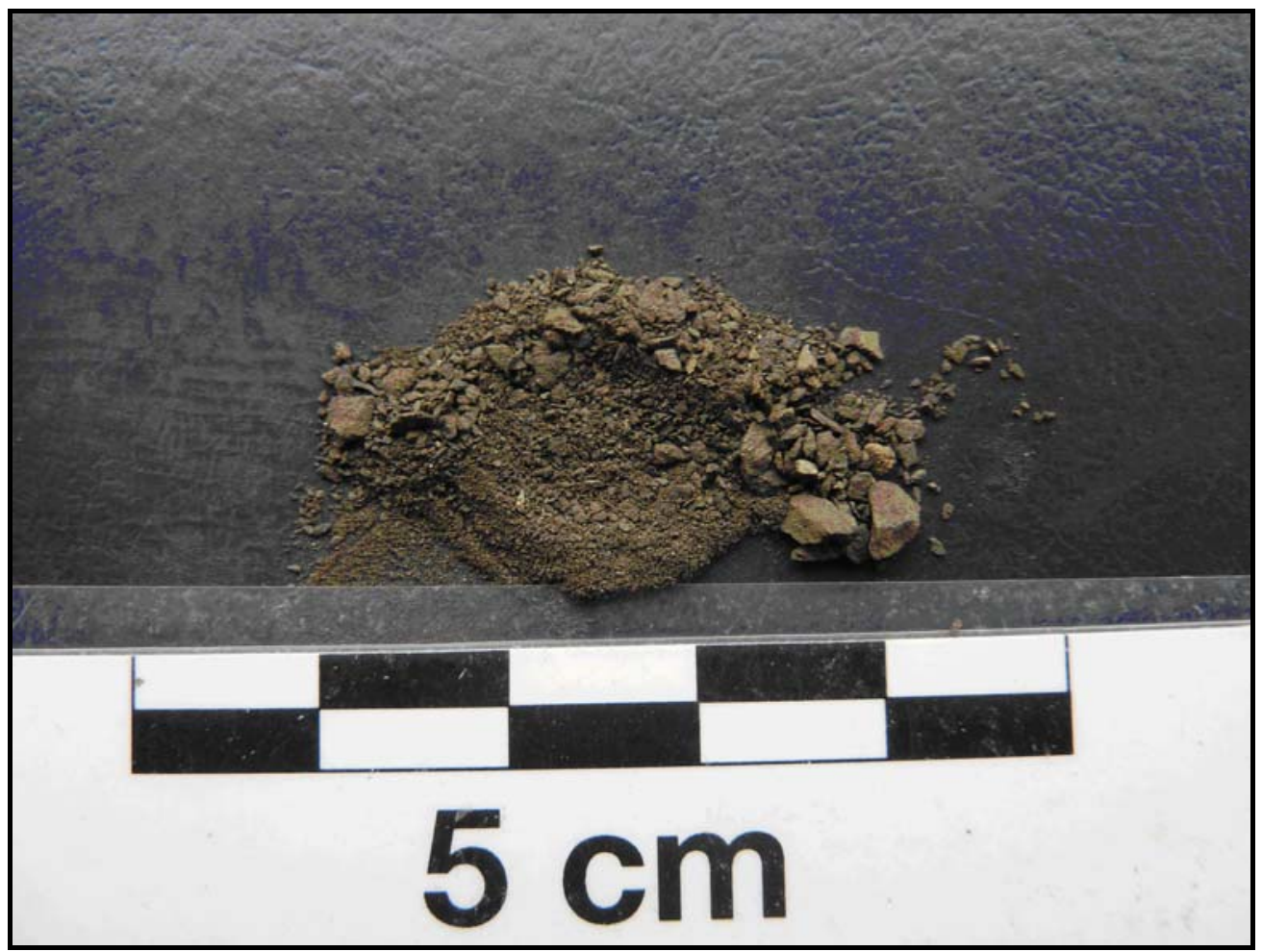

Figure 4.4: Dark brown, organic rich mudstone from sidewall core sample at $2512.4 \mathrm{~m}$ brt at Galleon-1. The mudstone also exuded a slight oily odour. This is representative of the organic Mudstone 3 facies within the core facies scheme here and relates to the Tartan Formation.

\subsubsection{Sandstone 1}

The Sandstone 1 facies consists of very light white brown to light brown, very fine to fine sandstone, friable and moderately well sorted (Figure 4.5). This facies was only encountered at Resolution-1 and because of its distinctive lithology and thickness in the well ( $200 \mathrm{~m}$ thick) was included as an individual facies. All the samples within this facies are fairly homogenous with occasional samples having glauconite grains present (e.g., $1640 \mathrm{~m}$ bkb at Resolution-1). 


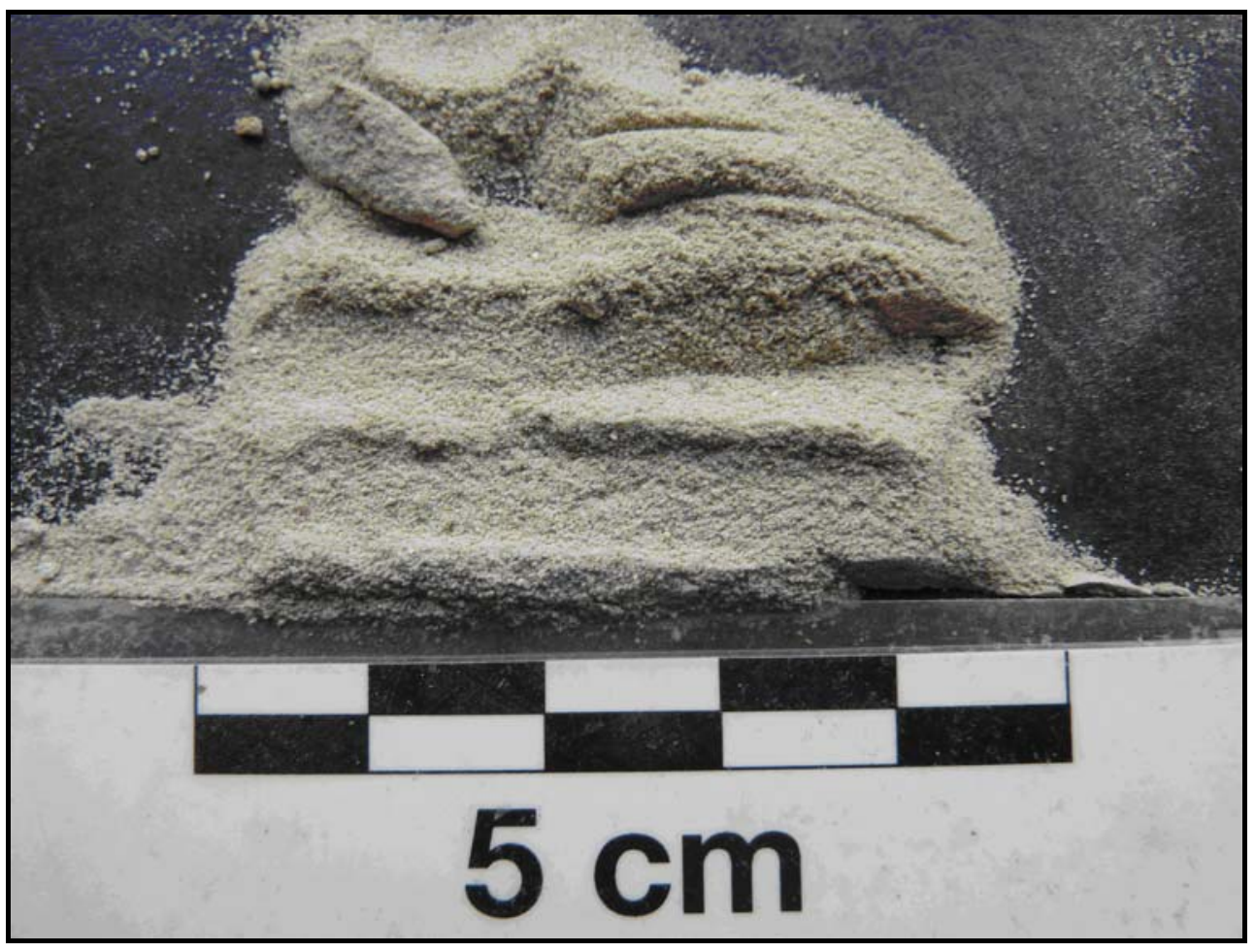

Figure 4.5: Representative sidewall core sample of Sandstone 1 facies from $1581 \mathrm{~m}$ bkb at Resolution-1.

\subsubsection{Sandstone 2}

The Sandstone 2 facies consists of blue grey, very fine sandstone (Figure 4.6). It is extremely hard and cemented, with quartz veins and glauconite present. A sample of this facies was from 5860ft (1786.12m) at Endeavour-1 and was present within the Paleocene interval. This facies occurs within the mudstones of the Moeraki Formation at Endeavour1. Although this sample represents a small interval, within one well, it was sufficiently different from the enclosing mudstones and the Sandstone 1 facies and therefore a new facies group was created. 


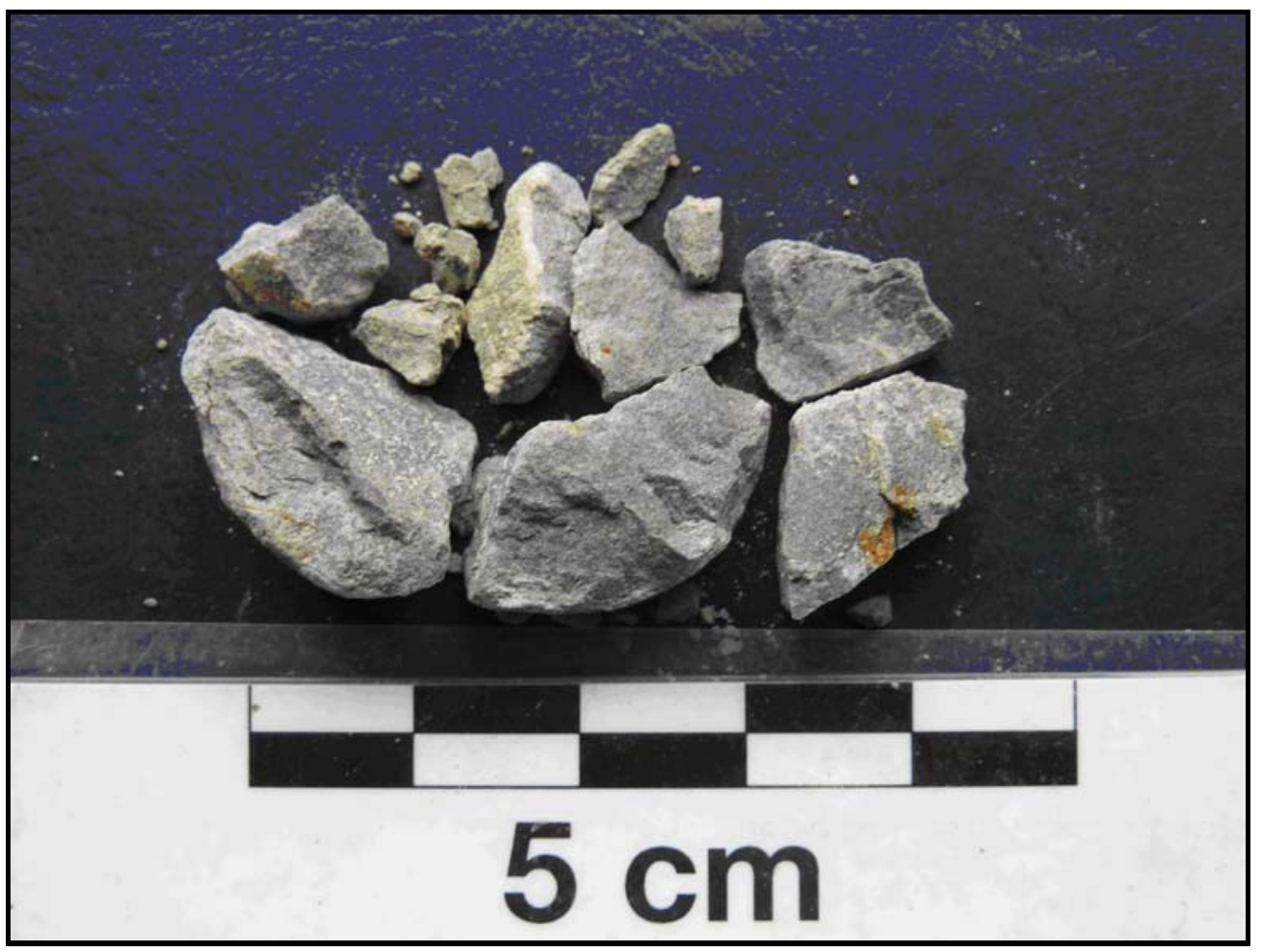

Figure 4.6: Sidewall core sample of very fine, blue-grey, extremely hard and cemented sandstone from $5860 \mathrm{ft}$ brt at Endeavour-1 lying stratigraphically within the Moeraki Formation. This is representative of the Sandstone 2 facies.

\subsubsection{Volcanics}

The volcanics encountered within the wells range from dark grey to brownish green sandstone, very poorly sorted, with angular fragments up to $2 \mathrm{~mm}$ at Resolution-1, to dark green basalt, crumbly, with abundant steam cavities and occasional xenoliths of muddy siltstone present at Endeavour-1 (Figure 4.7). 


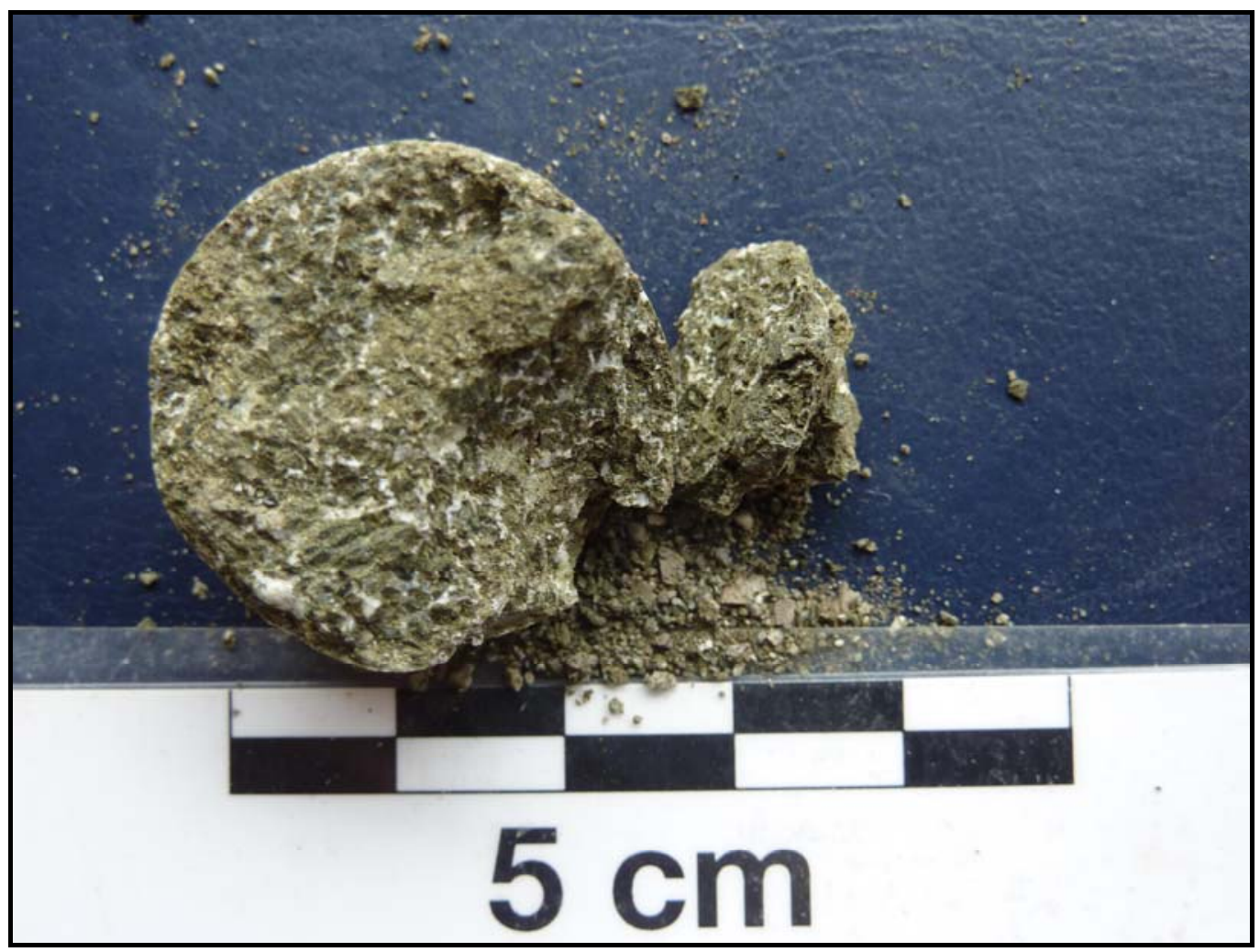

Figure 4.7: Dark green basalt, crumbly with abundant steam cavities, and occasional xenoliths of muddy siltstone from $1859.2 \mathrm{~m}$ bdf (below derrick floor) at Endeavour-1 and representative of the Volcanics facies.

\subsection{Interpretation}

The facies identified from lithological descriptions of sidewall cores from the Paleocene to Middle Eocene interval of the Canterbury Basin allows a basic interpretation of probable depositional environment of each facies. The interpretations are based on a limited dataset, but from this the following basic interpretations are possible. Mudstone facies 1 and 2 represent low energy deposition in a moderately deep marine environment inferred from the fine grain size of the sediments encountered. The Mudstone 1 facies was observed at all four wells and represents deposition at a low energy environment. Occasional glauconite grains present suggest that sedimentation rate was slow and in a moderately shallow marine (shelf) environment. Mudstone 2 facies was observed in all wells except Resolution-1 where its stratigraphic position is largely occupied by the coarser grained facies of Sandstone 1. The Mudstone 3 facies is notable because of its high organic content and despite its fine grain size, likely reflects shallow or marginal marine deposition with increased organic matter input and preservation. The Sandstone 1 and 2 facies are finegrained and moderately-sorted and likely to represent deposition in a higher energy, 
shallower marine environment than that represented by the Mudstone 1 and 2 facies. These interpretations are consistent with previous estimates of depositional environment and water depth interpreted from biostratigraphy and also agrees well with the accepted formation boundaries. Correlating these between wells across the basin suggests that in general sediment deposition was in a marine setting.

Within this Paleocene to Eocene interval, two facies observed are notable, the organic rich Mudstone 3 facies and the clean, uncemented sandstones of the Sandstone 1 facies. These correspond to the Tartan Formation and the Charteris Bay Sandstone respectively. The organic rich Mudstone 3 facies relates to a relatively thin interval and occurs within similar, though slightly lighter and non-organic, mudstones. The concentration of organic material within this facies suggests that there was a change in depositional conditions allowing for the accumulation and preservation of organic matter although what this change was is not evident from the lithofacies descriptions itself. The Sandstone 1 facies, previously described as the Charteris Bay Sandstone was observed in great thickness at Resolution-1. The sandy character of the sediments observed would suggest deposition at a higher energy environment and presumably shallower depths and contrasts with the persistent and widespread deposition of mudstones during the Paleocene at the other three wells. 


\subsection{Wireline Logs}

\subsection{Introduction}

Wireline logs measure geophysical properties of the subsurface penetrated by the exploration well using a variety of down hole logging instruments. Because wireline tools are usually run over the entire length of the drill hole, properties of the subsurface are recorded in a continuous and uninterrupted way and provide more complete data for subsurface correlation than studies based on outcrops and sidewall cores alone. Whole cores are usually not available over the entire length of the borehole but wireline logs generally are. From these geophysical properties, characteristics of the rock drilled such as lithology, porosity and pore fluid type and content may be deduced. Wireline log data used together with seismic reflection profiles, cuttings, sidewall core data and drill cores can provide a relatively complete picture of the sub-surface. Correlating wireline logs across wells provides information on the variations in sub-surface formation thickness and lithology. On a smaller scale, changes in log curve shape and relative increases and decreases in the $\log$ response provide information about the vertical and lateral facies variations.

In this project the wireline logs of the four open-file offshore wells in the Canterbury Basin were analysed. The wells are Galleon-1, Endeavour-1, Clipper-1 and Resolution-1 (Figure 1). The wireline logs at each of the wells were analysed for changes in their log responses in order to determine wireline facies and their lateral and vertical changes and well log correlation was carried out between the four wells to better understand the depositional history of Paleocene to Eocene strata. The sparse spread of wells made possible only one wireline log correlation panel between the four wells. In this chapter, the wireline log analysis of Paleocene and Eocene strata at the four offshore wells in the Canterbury Basin is discussed.

\subsection{Overview of Wireline Logs}

Wireline log data is recorded as a wireline logging tool is pulled up the drillhole. Standard wireline logging runs in exploration wells include gamma ray, various resistivity logging 
tools, spontaneous potential (SP), sonic, neutron and density logs (Table 5.1). These different logs and the properties they measure are discussed briefly below.

A Calliper log records the measurements of the size and shape of the drill hole and can be an important indicator of cave ins or shale swelling in the hole (Hearst et al., 1985). Variations in borehole diameter are measured by the Caliper tool as it is withdrawn from the bottom of the hole and the calliper log is printed as a continuous series of values of hole diameter with depth (Asquith and Gibson, 1982). Calliper logs are especially useful in evaporite sequences where soluble particles have been dissolved out (Cant, 1984).

The Spontaneous Potential log is also commonly called the self potential log or SP log. The log is recorded by measuring small electric potentials between different electrodes pulled up through the borehole and a grounded voltage at the surface. The change in voltage exists due to differences in the salinities of the drilling mud and the formation water. In shaly sections the SP response taken at the maximum level to the right will define a 'shale' line and deflections off this line will indicate permeable zones of rock containing fluid with different salinities than that of the drilling mud (Cant, 1984; Mann and Müller, 1988).

Resistivity logging is a method of well logging that works by characterising the rock or sediment in a borehole by measuring its electrical resistivity. Resistivity is a material property and is a measure of how strongly a material opposes the flow of electric current. In these logs, resistivity is measured using electrodes after current is supplied to the base of the tool, to eliminate the resistance of the contact leads. The log must run in holes containing electrically conductive mud or water. Most rock materials are essentially insulators while their enclosed fluids are conductors. Hydrocarbon fluids are an exception, as they have very high resistivity. The overall resistivity will be low when a formation is porous and contains salty water (e.g., North 1985). When the formation contains hydrocarbons, or contains very low porosity, its resistivity will be high. High resistivity values may indicate a hydrocarbon bearing formation.

Sonic log is a measure of a formations capacity to transmit sound waves and quantitatively is used to evaluate the porosity in liquid filled pores. It records the time taken for a compressional wave to travel through the drilling fluid and formation and back. The 
velocity of sound is dependent on the lithology, interconnected pore space and type of fluid (Cant, 1985). Coals and very porous rocks will have low interval velocities and tightly cemented rocks, for example, will have higher velocities (North, 1985).

Density logging is a well logging tool determining the bulk density of the rock and its fluids along a wellbore. Geologically, bulk density is a function of the density of the minerals forming a rock (i.e. matrix) and the enclosed volume of free fluids (porosity). Gamma rays emitted into the formation, are scattered by collision with electrons in the formation, and the number of returning gamma rays are counted to give the electron density which is a direct function of rock bulk density (Serra, 1986) .

Gamma ray logging is a method of measuring naturally occurring gamma radiation to characterise the rock or sediment in a borehole. It is the most useful wireline log for facies analysis (Cant, 1984). Different types of rock emit different amounts and different spectra of natural gamma radiation. In particular, shales usually emit more gamma rays than other sedimentary rocks, such as sandstone, gypsum, salt, coal, dolomite, or limestone because of increased concentration of radioactive potassium in their clay content, and because the cation exchange capacity of clay causes them to adsorb uranium and thorium (e.g., North 1985). This difference in radioactivity between shales and sandstones/ carbonate rocks allows the gamma tool to distinguish between shales and non-shales.

Although wireline logging is extremely useful for subsurface analysis, several factors need to be considered. The information from wells drilled represents at best a 'pin prick' in the basin and may not be representative of a formation as a whole. For example, finely interbedded lithologies below the resolution of the wireline logging tool can give rise to intermediate results unrepresentative of the actual lithologies. Also, the logs are an indirect method to gain information on the subsurface and can be affected by other factors such as the composition of drilling mud and borehole temperature. 


\begin{tabular}{|c|c|c|c|c|}
\hline Logs & $\begin{array}{l}\text { Property } \\
\text { Measured }\end{array}$ & Units & Uses & Comments \\
\hline Calliper & Borehole diameter & Inches & $\begin{array}{l}\text { Evaluate hole conditions } \\
\text { and reliability of other logs. }\end{array}$ & $\begin{array}{l}\text { Thick filter cake } \\
\text { (small hole) indicates } \\
\text { permeable zone }\end{array}$ \\
\hline $\begin{array}{l}\text { Spontaneous } \\
\text { Potential }\end{array}$ & $\begin{array}{l}\text { Natural electric } \\
\text { potential compared } \\
\text { to drilling fluid }\end{array}$ & $\begin{array}{l}\text { Millivolts } \\
(\mathrm{mv})\end{array}$ & $\begin{array}{l}\text { Lithology (in some cases), } \\
\text { correlation, curve shape } \\
\text { analysis, identification of } \\
\text { porous zones. }\end{array}$ & $\begin{array}{l}\text { Reservoir rocks kick } \\
\text { to the left. }\end{array}$ \\
\hline Resistivity & $\begin{array}{l}\text { Resistance to } \\
\text { electric current }\end{array}$ & $\begin{array}{l}\text { Ohm metres } \\
\text { (ohm m) }\end{array}$ & $\begin{array}{l}\text { Identification of coals, } \\
\text { bentonites, fluid } \\
\text { evaluation. }\end{array}$ & $\begin{array}{l}\text { Oil and gas kicks to } \\
\text { the right. }\end{array}$ \\
\hline Sonic & $\begin{array}{l}\text { Velocity of the } \\
\text { compressional } \\
\text { sound wave. } \\
\text { Measures interval } \\
\text { transit time. }\end{array}$ & $\begin{array}{l}\text { Microsecond } \\
\mathrm{s} / \mathrm{metre} \\
(\mathrm{ms} / \mathrm{m})\end{array}$ & $\begin{array}{l}\text { Identification of porous } \\
\text { zones, coal, tightly } \\
\text { cemented zones. }\end{array}$ & $\begin{array}{l}\text { Porous or gas filled } \\
\text { sediments kick to } \\
\text { left. Must know the } \\
\text { lithology (matrix) }\end{array}$ \\
\hline Neutron & $\begin{array}{l}\text { Hydrogen atom } \\
\text { density }\end{array}$ & $\begin{array}{l}\text { Percent } \\
\text { porosity }\end{array}$ & $\begin{array}{l}\text { Identification of porous } \\
\text { zones, cross plots with } \\
\text { sonic, density logs for } \\
\text { empirical separation of } \\
\text { lithologies. }\end{array}$ & $\begin{array}{l}\text { Gas reservoirs and } \\
\text { porous zones give } \\
\text { low readings. Used } \\
\text { in cased and uncased } \\
\text { wells. }\end{array}$ \\
\hline Density & $\begin{array}{l}\text { Bulk density } \\
\text { (electron density) }\end{array}$ & $\begin{array}{l}\text { Kilograms } \\
\text { per cubic } \\
\text { meter } \\
\left(\mathrm{gm} / \mathrm{cm}^{3}\right)\end{array}$ & $\begin{array}{l}\text { Identification of some } \\
\text { lithologies such as } \\
\text { anhydrite, halite, non } \\
\text { porous carbonates. }\end{array}$ & $\begin{array}{l}\text { Non porous rocks } \\
\text { kick to right. Must } \\
\text { know lithology to } \\
\text { interpret. }\end{array}$ \\
\hline Gamma Ray & $\begin{array}{l}\text { Natural } \\
\text { radioactivity }\end{array}$ & API units & $\begin{array}{l}\text { Lithology (shaliness), } \\
\text { correlation, curve shape } \\
\text { analysis. }\end{array}$ & $\begin{array}{l}\text { Shale kicks to right. } \\
\text { Coarse material kicks } \\
\text { to left. Used in cased } \\
\text { and uncased wells. }\end{array}$ \\
\hline
\end{tabular}

Table 5.1: Summary of Wireline logs. Modified after Cant (1984).

\subsection{Methods}

Wireline log analysis and correlation was done on the four offshore wells drilled in the Canterbury Basin; Galleon-1, Endeavour-1, Clipper-1 and Resolution-1. These wells cover a wide geographic area and provide good regional coverage. The data used in this study was from geophysical well logs (primarily gamma ray), sidewall core samples from the four wells (Chapter 4), existing biostratigraphic data from the original biostratigraphic 
reports and revised biostratigraphic data based on new analysis by previous workers (Pocknall, 1991; Simpson, 1993), the original well completion reports for the four wells: Petroleum Reports (PR) 648, 1146, 303 and 1036, and a review of the existing data in this study. Paleontological sample data was obtained from open file biostratigraphic reports providing information on depth, age, paleoenvironment, and key biomarkers. Previous biostratigraphic assessments of the wells were provided by the following authors who are listed here alphabetically:

- $\quad$ Endeavour-1 (Pocknall, 1991; Raine et al., 1994; Schroeder, 1971)

- $\quad$ Resolution-1 (Hornibrook et al., 1975)

- Clipper-1 (Crux, 1984; Raine et al., 1994; Simpson, 1993)

- Galleon-1 (Jones et al., 1986; Pocknall, 1991; Raine et al., 1994)

Lithology was interpreted by comparing wireline logs with sidewall core descriptions and where these were absent, from the original descriptions of sidewall core present in the well completion reports. Formation boundaries and Stage tops were revised based on updated biostratigraphic information and analysis of sidewall cores and geophysical logs and is presented in Table 5.2 and described in Section 5.4. Well sheets were made for the Paleocene to Eocene interval for all four wells incorporating the revised information (Appendix G). Well logs and other well data were from open file petroleum reports held by Crown Minerals. Seismic interpretation over this region was used to further support the well correlation and to map the stratigraphic units in the areas between the wells and into areas with no well coverage. A new well sheet template was made to incorporate only information relevant to this study. A review of the biostratigraphy in the four offshore wells is presented in Appendix B.

\subsection{Formation Tops and Chronostratigraphic surfaces}

This section details the review and revision of formation tops and chronostratigraphy from the well completion reports and justifies the changes made to the formation tops and chronostratigraphic horizons at each of the wells from the information originally presented in the well completion reports. All depths cited here are measured depths (MD) from rotary table (RT) or kelly bushing (KB). Original formation tops and chronostratigraphic information alongside their revised values are presented in Table 5.2. The formation tops at 
each of the wells are presented first in stratigraphic order from youngest to oldest and followed by chronostratigraphic surfaces from youngest to oldest.

\subsubsection{Top Hampden Formation}

The top of this formation generally marks the impedance contrast between limestones above to a mudstone lithology below and by variable increases in the gamma ray response. The top Hampden Formation at Galleon-1 is marked by a sharp increase down hole in the gamma ray response. It marks the transition from the Amuri limestone above to the Hampden Formation mudstones below and was picked at $1888 \mathrm{~m}$. The top of the Hampden Formation at Endeavour-1 was picked at the lithology change from the Miocene limestones above to the mudstones of the Hampden Formation below at $1263 \mathrm{~m}$. However, there is a slight lithological change within the Hampden Formation where above $1534 \mathrm{~m}$ mudstones contain variable calcareous contents (Wilding and Sweetman, 1971) while below $1534 \mathrm{~m}$ the mudstones are predominantly non-calcareous. At Clipper-1, the top of the Hampden Formation is picked at $2388 \mathrm{~m}$ at the change from the Amuri limestone above to a mudstone lithology below. It is marked by an increase in the gamma ray response down hole at $2387 \mathrm{~m}$. The top of the Hampden Formation/ Ashley Mudstone at Resolution1 is picked at $1328 \mathrm{~m}$ at the change from the Amuri limestone above to a mudstone lithology below. It is marked by an increase in the DT log down hole. The gamma ray log surprisingly does not show a marked change at this level as seen in the other wells.

\subsubsection{Base Hampden Formation}

The base of the Hampden Formation also marks the top of the underlying Moeraki Formation which is lithologically very similar. It is marked at Galleon-1 by an increase in the gamma ray response down hole. The Moeraki Formation mudstones below are different only in being a darker grey. The mudstones of the Hampden Formation at Galleon-1 are lighter coloured and the base of this formation was picked at $2402 \mathrm{~m}$. The base of the Hampden Formation at Endeavour-1 is characterised on the gamma ray log by a slight decrease down hole at $1650 \mathrm{~m}$. The lithologies below this level are different from the mudstones above in that they are characteristically softer and are present at the top of the Moeraki Formation (Wilding and Sweetman, 1971). The base of the Hampden Formation at Clipper-1 is marked on the gamma ray log by a slight increase down hole and 
on the density log by a sudden decrease. This was picked at $2575 \mathrm{~m}$. Lithologically, the sediments above have various limestone contents, and below are marked by non-calcareous lithologies. The base of the Hampden Formation/ Ashley mudstone at Resolution-1 is marked by a slight increase in the gamma ray response down hole at $1476 \mathrm{~m}$ and coincides with a change in lithology to a thin volcanic layer, the View Hill Volcanics, which approximates to the top of the Paleocene at the well. The Base of the Hampden Formation is coincident with the top of the Moeraki Formation.

\subsubsection{Base Moeraki Formation}

The base of the Moeraki Formation mudstones is represented at Galleon-1 by the transition into the organic rich mudstones of the Tartan Formation at 2506m and also marked by increases in the gamma ray response. At Clipper-1, the Moeraki Formation encloses the Tartan Formation and the Endeavour Volcanics. Below these two units the Moeraki Formation is present again and the base of this lower unit of the Moeraki Formation is within the Cretaceous. At Clipper-1 the base of the Moeraki Formation is picked at $3168 \mathrm{~m}$ and marked by an increase down hole in the NPHI log, a decrease in the density $\log$ and a decrease in the DT log. The Moeraki Formation is absent at Resolution-1.

\subsubsection{Top Tartan Formation}

The top of this formation marks the transition from non-organic sediments above to organic sediments below and is also represented by conspicuous increases in gamma ray response. At Galleon-1, the top of the Tartan Formation is picked at a sudden rise in gamma ray response down hole at $2506 \mathrm{~m}$. It is also picked from the lithological descriptions at a change from the Moeraki Formation above to the organic rich Tartan Formation below. At Endeavour-1, the top of the Tartan Formation is characterised by a sharp increase down hole in the gamma ray response at $1729 \mathrm{~m}$ corresponding to the lithological change from the mudstones of the Moeraki Formation into the organic rich Tartan Formation mudstones. Similar to its characteristics in Galleon-1 and Endeavour-1, the top of the Tartan Formation at Clipper-1 is characterised by a sharp increase down hole in the gamma ray response corresponding to the lithological change down hole from the Moeraki Formation mudstones, into the organic rich Tartan Formation mudstones at $2578 \mathrm{~m}$. The Tartan Formation is absent at Resolution-1. 


\subsubsection{Base Tartan Formation}

The base of the Tartan Formation is picked where the gamma ray response decreases again from its high over the Tartan Formation interval in conjunction with sidewall core descriptions showing a change down hole from the organic rich mudstone of the Tartan Formation to less organic rich sediments below. At Galleon-1 it is picked at the transition of the Tartan Formation to the Katiki Formation mudstones below at $2522 \mathrm{~m}$. The base of the Tartan Formation at Endeavour-1 is marked on the gamma ray log by a sudden decrease in gamma ray response and by descriptions of the sidewall cores showing transition out of the organic rich layer of the Tartan Formation at $1758 \mathrm{~m}$ back into the less organic rich mudstones of the Moeraki Formation. At Clipper-1 it is marked by a sudden decrease in the gamma ray response down hole and by descriptions of the sidewall cores showing transition out of the organic rich layer of the Tartan Formation at $2787 \mathrm{~m}$ and back into the less organic rich mudstones of the Moeraki Formation.

\subsubsection{Top Endeavour Volcanics}

The Endeavour Volcanics were encountered at Endeavour-1 and Clipper-1. At Endeavour-1, the top of this layer is marked on the gamma ray log by a sharp decrease down hole at $1809 \mathrm{~m}$. This is in agreement with lithological descriptions of sidewall cores from $1809 \mathrm{~m}-1942 \mathrm{~m}$ which show a volcanic breccia encountered within this interval. At Clipper-1 the top of this layer is marked on the gamma ray log by a small, sharp decrease down hole at $3005 \mathrm{~m}$. This is in agreement with lithological descriptions from the Clipper-1 well completion report showing at least three thin tuffaceous units present.

\subsubsection{Base Endeavour Volcanics}

At Endeavour-1, the base of the Endeavour Volcanics was picked on the gamma ray log where there is a sudden increase down hole coinciding with the change from the volcanic breccia above to the mudstones of the Lower Moeraki Formation. The Endeavour Volcanics were recorded at Endeavour-1 in four units, interbedded with cherty mudstones and the base was picked at 1942m. At Clipper-1, the base of the Endeavour Volcanics was picked on the gamma ray log where there is a small sharp increase coinciding with the 
change from the volcanic breccia above to the mudstones of the Lower Moeraki Formation. The gamma ray response marking the Endeavour Volcanics at Clipper-1 is not as sharp and noticeable as its response in the Endeavour-1 well. However, correlation with the sidewall core descriptions from the original well completion report PR 1146 (which shows small quantities of tuff developed in this interval) indicates the presence of the volcanics at this interval. The base was picked at $3168 \mathrm{~m}$.

\subsubsection{Top Moeraki Formation (lower)}

This was only picked at Endeavour-1 where it is present below the Endeavour Volcanics. This top coincides with the base of the Endeavour Volcanics at $1942 \mathrm{~m}$. The base of the Lower Moeraki Formation is within the Cretaceous interval and marks a change from the Moeraki Formation mudstones to the siltstone lithology of the Katiki Formation below.

\subsubsection{View Hill Volcanics}

These volcanics were only encountered at Resolution-1. Within Resolution-1, two thin layers of volcanics were encountered within the Paleocene interval; one at the top of the Charteris Bay Sandstone and present between $1476 \mathrm{~m}$ and $1480 \mathrm{~m}$, and the other within the Charteris Bay Sandstone between 1555m and 1573m. These two thin layers are recognised on the gamma ray logs and in the sidewall core samples described (Figure 5.2).

\subsubsection{Top Charteris Bay Sandstone}

The Charteris Bay Sandstone was only encountered at Resolution-1. The top of this is marked by a sudden decrease in the gamma ray response down hole and coincides with the change from the thin volcanic layer above to the sandstone lithology of the Charteris Bay Sandstone observed in sidewall core samples.

\subsubsection{Base Charteris Bay Sandstone}

The base of this formation at Resolution-1 is marked on the gamma ray log by a sharp increase down hole at $1660 \mathrm{~m}$. Although similar fine-grained sandstone lithologies are encountered below this level they are different in being more silty, variably calcareous and 
micaceous. The base of the Charteris Bay Sandstone also marks the top of the Conway Formation at Resolution-1.

\subsubsection{Base Oligocene}

This is generally characterised by a change from a limestone lithology above to a mudstone lithology of Eocene sediments below. At Galleon-1 this reflector was picked at the base of the Oligocene to latest Eocene Amuri Limestone. It is marked by a pronounced gamma ray increase and a DT log increase down hole, and marked lithologically by the transition from limestones above to mudstones below. The biostratigraphic top was picked at $1880 \mathrm{~m}$. This is just above the base of the limestone. However, for this study the associated reflector and the depth for well correlation was taken at $1890 \mathrm{~m}$ at the transition of the limestone to the mudstone. At Endeavour-1 this is marked by a pronounced increase in gamma ray response down hole, a sharp increase in the DT log and is also picked biostratigraphically. The Runangan (Latest Eocene) sediments at Endeavour-1 are either attenuated or eroded and this surface represents the erosion of Early Miocene to Late Eocene sediments (Wilding and Sweetman, 1971) and was picked at 1263m. At Clipper-1 this was picked biostratigraphically at $2340 \mathrm{~m}$ using information from the well completion report which used the first down hole appearance of Globigerapsis index to mark the penetration of Runangan to Late Porangan sediments (Appendix B) (Crux, 1984). It also correlates to the base of the Amuri Limestone which here is part of the Upper Eocene. It is marked by an increase in the gamma ray response and by a lithological change from limestone above to mudstones below. At Reolution-1 this was picked biostratigraphically at $1332 \mathrm{~m}$ from the first appearance of Globigerapsis index and Globigerina ex gr. linaperta which indicate an age no younger than Runangan (Hornibrook et al., 1975), and this pick was also used in this study. There is also a lithological change here from a sandy limestone above to a silty mudstone below.

\subsubsection{Top Paleocene}

The top Paleocene was picked in conjunction with biostratigraphy and from an associated increase in gamma ray response. The top Paleocene is marked by an increase down hole in the gamma ray response at Galleon-1 at $2445 \mathrm{~m}$. The information from biostratigraphy is not clear on the depth of the top Paleocene although it is in the region of $2381.0 \mathrm{~m}$ and 
2603m (Pocknall, 1991). This chronostratigraphic top was therefore picked from the gamma ray response, as a similar response is also seen at Clipper-1. From the recorded biostratigraphy at Endeavour-1 it was not possible to separate the Teurian from the Waipawan stage and hence in the original biostratigraphic report they were taken together (Schroeder, 1971). A more confident estimate of the Dt-Dw boundary (Paleocene-Eocene boundary) was placed at above $1698 \mathrm{~m}$ by Pocknall (1991). The depth was tentative and at Endeavour-1, the top of the Paleocene was marked by mapping the top Paleocene reflector from Resolution-1 and Clipper-1 and extending it to Endeavour-1. The reflector when converted to depth from the depth information in the well logs corresponds to $1676 \mathrm{~m}$. At Clipper-1 this is marked by an increase in gamma ray response, resistivity and a decrease in sonic interval transit time corresponding to a change in mudstone and siltstone lithologies and an increase in argillaceous content. This was picked biostratigraphically from the first down hole occurrence of Teurian species (Crux, 1984) and is of similar depth to the original prognosed depth. At Resolution-1 the top Paleocene was not defined in the original biostratigraphic report for the well and the interval from $1413.5 \mathrm{~m}-1403 \mathrm{~m}$ was assigned an age from Heretaungan to Teurian. The interval from 1410m-1415m contains Elphidium hamdenense indicating a Heretaungan age (Hornibrook et al., 1975). This species is also present at $1428 \mathrm{~m}$ and $1443 \mathrm{~m}$. Below $1443 \mathrm{~m}$ samples were not indicative of age and the sidewall core sample at $1474.5 \mathrm{~m}$ Bolivinopsis compta and Bolivinopsis spectabilis which indicates a Teurian age (Hornibrook et al., 1975), and therefore the top of the Paleocene in this study was picked here at $1475 \mathrm{~m}$.

\subsubsection{Top Cretaceous}

The original depth of the top Cretaceous at Galleon-1 was inferred to be $2678 \mathrm{~m}$ from the original well completion report (Jones et al., 1986). However this was later revised in 1991 by analysis focussing on the Late Cretaceous to Early Eocene interval in the Galleon-1 well (Pocknall, 1991). This interval was brought to between $2642 \mathrm{~m}-2645 \mathrm{~m}$ using the upper limits of Tricolporites lilliei, Quadraplanus brossus and Beaupreaidites $n$ sp. which are only known from Late Cretaceous sequences elsewhere (Pocknall, 1991; Raine, 1994). The top of the Cretaceous in this study at Galleon-1 was picked at $2645 \mathrm{~m}$ in agreement with revised biostratigraphic analysis by Pocknall (1992) and Raine (1994) and at Endeavour-1 it was picked at $1975 \mathrm{~m}$ where the first appearance of the foraminiferal species Dorthia aff. Elongate was recorded (Pocknall, 1992). This was used to mark the 
top of the Haumurian Stage (Late Cretaceous). At Clipper-1 the top Cretaceous (top Mata series) is marked by an increase in gamma ray response, an increase in resistivity response and a decrease in sonic interval transit time. Paleontologically, it is constrained by the identification of Teurian fauna till $3165 \mathrm{~m}$ brt and the recognition of Haumurian Stage fauna at 3190m (Simpson, 1993). The top Cretaceous was originally picked at $3185 \mathrm{~m}$ at Clipper-1 using the appearance of Isabelidinium drugii at $3175 \mathrm{~m}$ which indicates Earliest Teurian age (Crux, 1984). A subsequent review by Raine (1994) showed Cretaceous sediments had been penetrated at $3190 \mathrm{~m}$ based on the presence of Gaudryina healyi and hence the top Cretaceous in this study was picked at $3185 \mathrm{~m}$. The pick for the top Cretaceous for the Resolution-1 well differed from the one in the original biostratigraphic report for the well, PR 648. At $1675 \mathrm{~m}$ the assemblage of three species, Cyclammina elegans, Gaudryina healyi and Bathysiphon sp., were indicative of Haumurian age (Hornibrook et al., 1975). In the original report the interval from $1490 \mathrm{~m}$ to $1675 \mathrm{~m}$ yielded no foraminifera and the age of this interval was tentatively assigned to the Mata Series (Late Cretaceous). However recent work by GNS (Raine, J.I., pers. comm.) identified the dinoflagellate Palaeoperidinium pyrophorum at $1635 \mathrm{~m}$ which indicates Early Teurian age. The foraminifera Gaudryina healyi which is an index species for the Haumurian (Late Cretaceous) was only present from $1695 \mathrm{~m}$. The Cretaceous-Tertiary boundary at the midWaipara section in onshore Canterbury occurs within the glauconitic sandstone of the upper Conway Formation (Browne and Field, 1985; Vajda and Raine, 2003). Since definite indicators of Cretaceous age were only present from $1695 \mathrm{~m}$, within the upper part of the Conway Formation, the top was picked at $1685 \mathrm{~m}$. 


\begin{tabular}{|c|c|c|c|c|c|c|c|c|}
\hline \multirow{2}{*}{ Stage Tops } & \multicolumn{4}{|c|}{ Original from Well Completion Report } & \multicolumn{4}{|c|}{ Revised Stage Tops } \\
\hline & Galleon-1 & Endeavour-1 & Clipper-1 & Resolution-1 & Galleon-1 & Endeavour-1 & Clipper-1 & Resolution-1 \\
\hline $\begin{array}{l}\text { Base } \\
\text { Oligocene }\end{array}$ & 1880 & 1263 & 2350 & 1328 & 1900 & 1265 & 2340 & 1335 \\
\hline $\begin{array}{l}\text { Top } \\
\text { Paleocene }\end{array}$ & 2475 & 1615 & 2692 & 1475 & 2445 & 1676 & 2700 & 1475 \\
\hline $\begin{array}{l}\text { Top } \\
\text { Cretaceous }\end{array}$ & 2678 & 1975 & 3167.5 & 1685 & 2645 & 1975 & 3185 & 1685 \\
\hline \multirow{2}{*}{$\begin{array}{l}\text { Formation } \\
\text { Tops }\end{array}$} & \multicolumn{4}{|c|}{ Original from Well Completion Report } & \multicolumn{4}{|c|}{ Revised Formation Tops } \\
\hline & Galleon-1 & Endeavour-1 & Clipper-1 & Resolution-1 & Galleon-1 & Endeavour-1 & Clipper-1 & Resolution-1 \\
\hline $\begin{array}{l}\text { Top } \\
\text { Hampden } \\
\text { Fm } \\
\end{array}$ & \multirow{9}{*}{$\begin{array}{l}\text { No } \\
\text { Formatio } \\
\mathrm{n} / \text { Group } \\
\text { informati } \\
\text { on in PR }\end{array}$} & 1258 & 2388 & \multirow{9}{*}{$\begin{array}{l}\text { No } \\
\text { Formation/ } \\
\text { Group } \\
\text { informatio } \\
\mathrm{n} \text { in PR }\end{array}$} & 1900 & 1258 & 2388 & 1328 \\
\hline $\begin{array}{l}\text { Base } \\
\text { Hampden } \\
\text { Fm } \\
\end{array}$ & & 1493 & 2410 & & 2402 & 1650 & 2575 & 1476 \\
\hline $\begin{array}{l}\text { Top } \\
\text { Moeraki Fm }\end{array}$ & & 1493 & 2692 & & 2402 & 1650 & 2575 & Absent \\
\hline $\begin{array}{l}\text { Base } \\
\text { Moeraki Fm }\end{array}$ & & 1975 & 2833 & & 2506 & 1809 & 3005 & Absent \\
\hline $\begin{array}{l}\text { Top Tartan } \\
\text { Fm }\end{array}$ & & Not Picked & $\begin{array}{c}\text { Not } \\
\text { Picked }\end{array}$ & & 2506 & 1729 & 2756 & Absent \\
\hline $\begin{array}{l}\text { Base Tartan } \\
\text { Fm. }\end{array}$ & & Not Picked & $\begin{array}{c}\text { Not } \\
\text { Picked }\end{array}$ & & 2522 & 1758 & 2787 & Absent \\
\hline $\begin{array}{l}\text { Top Katiki } \\
\text { Fm }\end{array}$ & & 1975 & 3168 & & 2522 & 1981 & 3168 & $\begin{array}{c}\text { Below } \\
\text { Paleocene }\end{array}$ \\
\hline $\begin{array}{l}\text { Top } \\
\text { Charteris } \\
\text { Bay } \\
\text { Sandstone }\end{array}$ & & Absent & Absent & & Absent & Absent & Absent & 1480 \\
\hline $\begin{array}{l}\text { Base } \\
\text { Charteris } \\
\text { Bay } \\
\text { Sandstone }\end{array}$ & & Absent & Absent & & Absent & Absent & Absent & 1660 \\
\hline
\end{tabular}

Table 5.2: List of original and revised Stage boundaries and formation tops. 


\subsection{Lithology and wireline log character}

\subsubsection{Moeraki Formation}

The Moeraki Formation typically has a relatively high gamma ray log reading and shows two high peaks to the right. This is seen at Galleon-1 and Clipper-1 (Figure 5.1). The first deviation down hole marks the top of the Paleocene reflector at Galleon-1 and Clipper-1. However this first peak down hole is not seen at Endeavour-1. Although the gamma ray log deviation at this level at Galleon-1 and Clipper-1 is significant, no corresponding lithological change is observed from sidewall core samples. Sidewall core descriptions from the well completion report for Clipper-1 noted an unusual smell for samples coincident with the level of the first high gamma ray response. This could possibly be a reason for the high reading at this well. Sidewall core samples from Galleon-1 observed in this study showed no lithological change at the level of the first gamma ray peak. The Moeraki Formation is absent at Resolution-1. The second gamma ray peak down hole within the Moeraki Formation corresponds to the Tartan Formation.

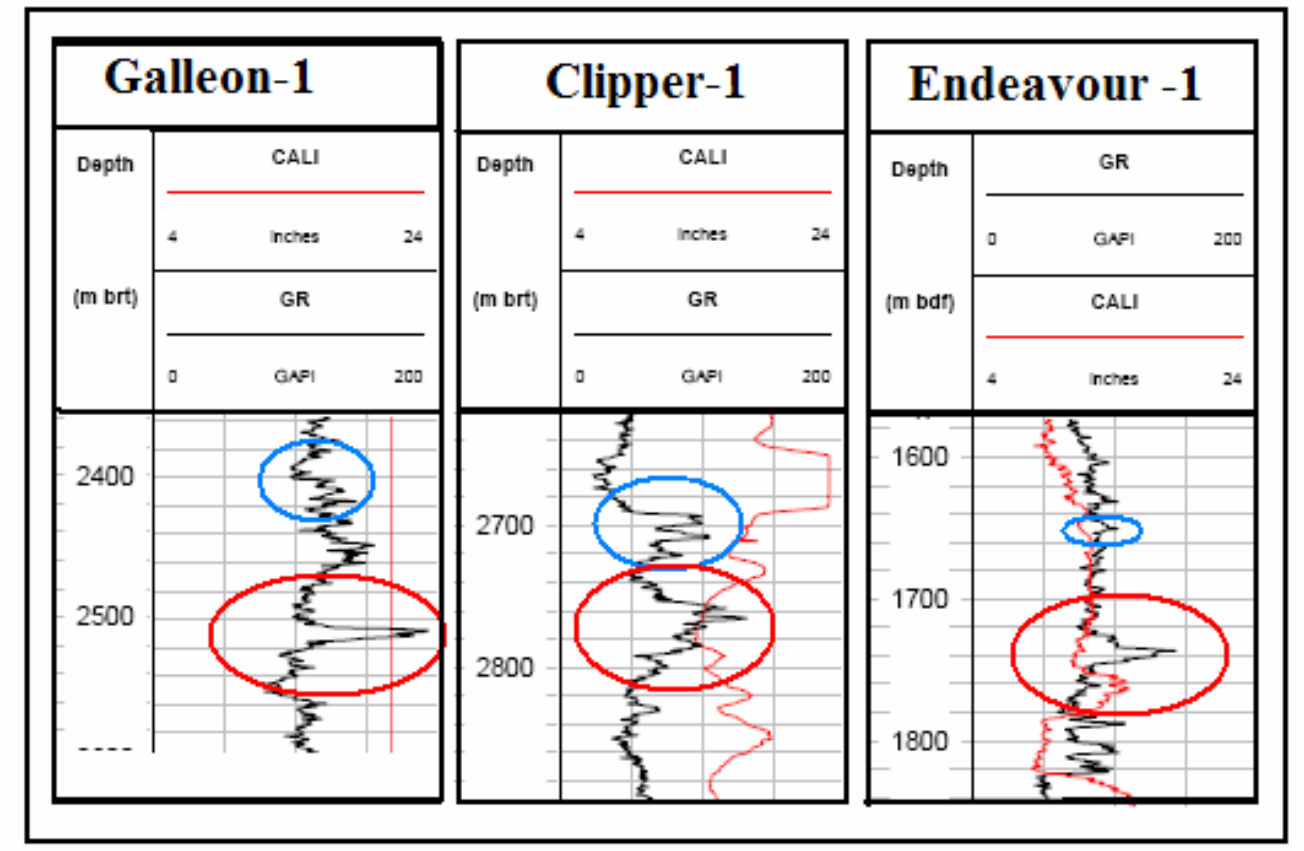

Figure 5.1: Gamma ray log motifs of the top Moeraki Formation (blue circle) and the Tartan Formation (red circle). The top of the Moeraki Formation is a significant peak in the gamma ray log at Clipper-1. At Galleon-1 and Endeavour-1, it is still seen although it is not as pronounced as its expression in the Clipper-1 well. The Tartan Formation log motif shows the significant increase in gamma ray response and has the thickest section developed in the Clipper-1 well. 


\subsubsection{Charteris Bay Sandstone}

The Charteris Bay Sandstone was encountered in the northeast of the study area at Resolution-1. The gamma ray log reading shows a typical decrease down hole from the Ashley Mudstone to the Charteris Bay Sandstone indicating sandstones or coarser grained clastics than those present in the formations above the Charteris Bay Sandstone (Figure 5.2). Towards the middle of the formation, there is a sudden increase and then a decrease down hole in the gamma ray response marking a thin layer of volcanics, the lower View Hill Volcanics seen in sidewall core samples. Overall, the gamma ray log response shows a slightly coarsening upwards package punctuated by the appearance of the volcanic layer in between (Figure 5.2). This is interpreted as a slight change to higher energy conditions during deposition of the sandstones possibly indicating a shallowing and regression.

Within the study area these sandstones are only present in the Resolution-1 well.

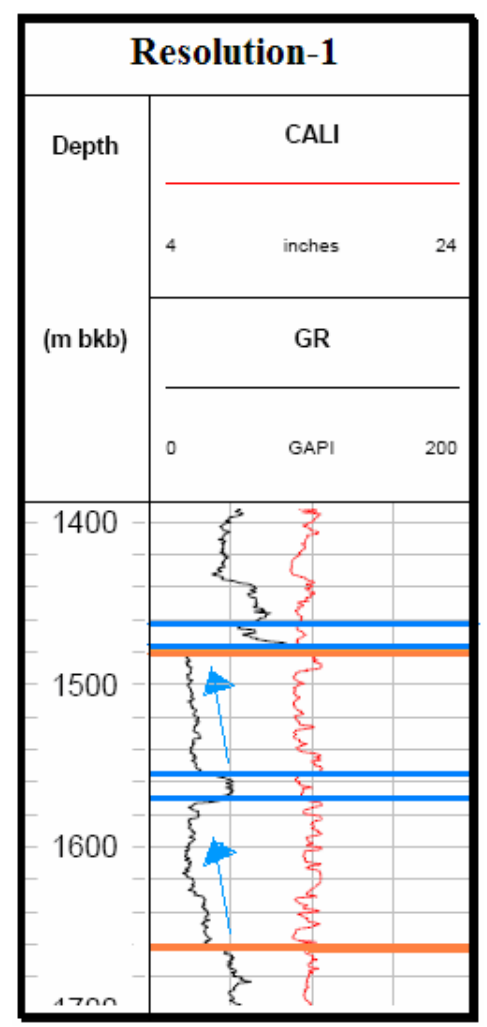

Figure 5.2: Gamma ray log motif of the Charteris Bay Sandstone at Resolution-1. Orange horizontal lines enclose the Charteris Bay Sandstone and blue horizontal lines enclose a thin volcanic layer above and within the Charteris Bay Sandstone. Note the sharp upper and basal contacts of the sandstone and the spiky character suggestive of interbedding with finer sediments. Blue arrows show a slight coarsening or cleaning upwards through the Charteris Bay Sandstone. 


\subsubsection{Tartan Formation}

The Tartan Formation is a thin organic rich layer of mudstone present within the Moeraki Formation at Endeavour-1 and Clipper-1 and towards the top of the Katiki Formation at Galleon-1. It is absent towards the northeast of the study area towards Resolution-1. The Tartan Formation has a distinctive gamma ray log response. It is seen as a sudden increase and decrease down hole in the gamma ray response (Figure 5.1, red circle)

\subsubsection{Hampden Formation}

The Hampden Formation gamma ray log response is similar to the Moeraki Formation. The Hampden Formation comprises mudstones and in general these give relatively high gamma ray responses. At Clipper-1 the gamma ray log through the Hampden Formation shows a fining upwards sequence and this is here interpreted to show a deepening during deposition of the Hampden Formation (Figure 5.3). A slight fining upwards motif is also seen at Resolution-1 and Galleon-1 (Figure 5.3).

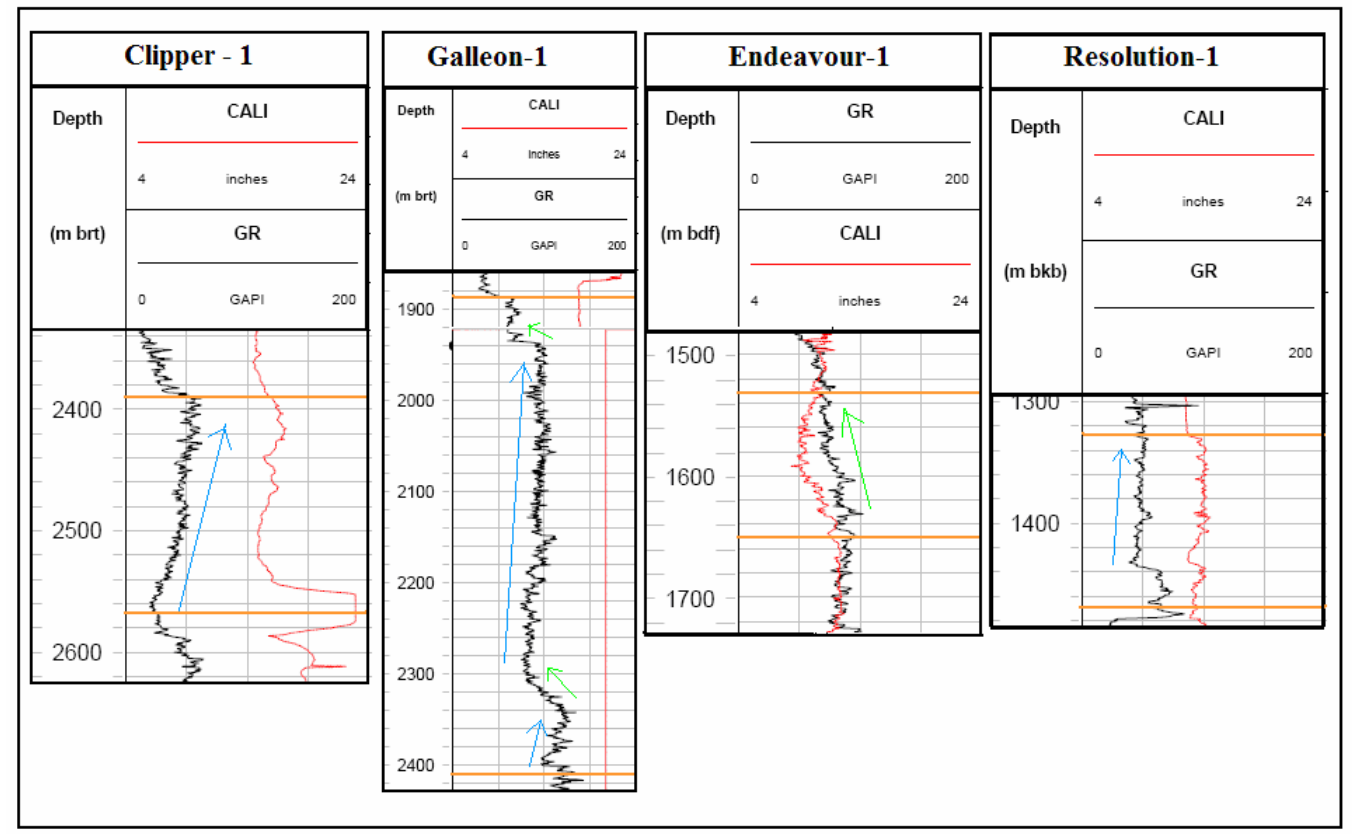

Figure 5.3: Gamma ray log characteristics of the Hampden Formation mudstones and its equivalent, the Ashley Mudstone at Resolution-1. Blue arrows show fining upwards and green arrows shows coarsening upwards sequences. Horizontal orange lines show the top and base of the Hampden Formation. Note the fining upwards sequence at Clipper-1, Galleon-1 and Resolution-1 and a slight coarsening upwards at Endeavour-1. 


\subsection{Well correlation}

\subsubsection{Methods}

Data from the four offshore wells were used to construct a well correlation panel for Teurian to Runangan age sediments (Figure 5.4). The panel trends roughly southwest to northeast, from Galleon-1 to Resolution-1 (Figure 5.4, Inset map). Stage boundaries were defined by reviewing previous updated biostratigraphic analysis, and formation tops were defined through analysis of wireline logs in conjunction with lithofacies descriptions of the Paleocene and Eocene section (Section 5.4). Most of the original biostratigraphic reports for the four wells have been updated since they were first done and accordingly the well correlation presented here is new. The aim of the correlation between the wells is to provide further insights into the depositional environment of the Canterbury Basin during the Paleocene and Eocene.

Tops of stage boundaries and formations were picked where there were correlations between the wireline log signatures of wells. Tops of stage boundaries were added in from biostratigraphic information where these did not have a corresponding wireline log response (Section 5.4). For example, the top of the Haumurian stage marking the top of the Cretaceous does not have a marked wireline log response at any of the wells except possibly at Resolution-1. In such cases the top at each well was picked from biostratigraphy. With respect to the top Paleocene and the top Tartan Formation, the correlation was done based on the log signatures. Where the correlation proved difficult, especially between Clipper-1 and Resolution-1, seismic profiles were used to aid the correlation.

The well correlation shown in Figure 5.1 shows one solution that complies with lithostratigraphic, chronostratigraphic, and depositional framework and has been constrained by seismic correlation.

\subsection{Results and discussion}

The well correlation presented in Figure 5.4 shows Paleocene to Eocene sediments correlated between the four wells Galleon-1, Endeavour-1, Clipper-1 and Resolution-1. During the Teurian, deposition of the mudstones of the Katiki Formation occurred at 
Galleon-1, which has the thickest section of the Katiki Formation deposited in the Paleocene interval within the study area. The Katiki Formation deposited during the Paleocene thins out towards the northeast and between Clipper-1 and Resolution- 1 the Katiki Formation and its equivalent, the Conway Formation at Resolution-1 only just extend into the Paleocene.

During the Teurian a thick sequence of the Charteris Bay Sandstone was deposited at Resolution-1. From the well correlation panel in Figure 5.4, the Charteris Bay Sandstone is seen to be present only around the area of the Resolution-1 well and it is absent at the other three wells. The extent of the Charteris Bay Sandstone differs from earlier reports as seismic interpretation in this study has shown it to extend further southwest, from Resolution-1 to Clipper-1.

At Endeavour-1 and Clipper-1, the Katiki Formation is overlain by the Endeavour Volcanics. About 130m of the volcanics were encountered at Endeavour-1 and about $160 \mathrm{~m}$ of mudstones mixed with a small percentage of volcanic material at Clipper -1 . This volcanism however appears to have only been active around the local area of these two wells.

The Moeraki Formation was deposited during the Paleocene and is present at all wells except Resolution-1. These mudstones at Endeavour-1 and Clipper-1 enclose the thin layer of the organic rich Tartan Formation. At Galleon-1 the Moeraki Formation overlies the Tartan Formation. The Moeraki Formation extends into the Eocene and towards the northeast, towards Resolution-1, was previously thought to grade/ interfinger into the Charteris Bay Sandstone (eg, Field and Browne, 1989a). This transition is seen on many seismic lines (Figure 3.4 D; Figure 3.12, Figure 3.13) and seismic correlation again helped pick out this transition. This transition may however be more complex as it is not readily evident what the nature of this transition is. On seismic a clear downlap surface of the top Charteris Bay Sandstone onto the top Cretaceous reflector was mapped and is seen in the isochore maps, where the thickness of the Charteris Bay Sandstone becomes zero towards the southwest, between Resolution-1 and Clipper-1 (Figure 3.23). There is a possibility that this surface is erosional and that the sediments of the adjacent Moeraki Formation onlap onto it. This would mean that the Charteris Bay Sandstone is older than the Moeraki Formation mudstones. Another possibility is that the facies at this part of the basin change 
rapidly so that the transition between mudstones to sandstones occurs quickly and this impedance contrast change is captured on seismic. However, subtle onlap is observed against the Charteris Bay Sandstone by the Moeraki Formation mudstones, and GNS (2009) suggests that the Paleocene sediments at Resolution-1 (towards the northeast) are composed of Early Teurian age sediments, and that Late Teurian sediments are unrecorded there. This would further indicate that Late Paleocene mudstones of the Moeraki Formation onlap onto the younger Charteris Bay Sandstone.

The Tartan Formation is a thin organic rich layer with an easily discernible gamma ray log signature. Log correlation was possible through the three wells where it is present and seismic interpretation enabled the 'pinch-out' between Clipper-1 and Resolution-1 to be mapped. Therefore the interpretation supported here is that, based on seismic interpretation, and the absence of the Tartan Formation at Resolution-1, the Tartan Formation pinches out towards Resolution-1. The Tartan Formation is a relatively thin layer and for the most part only encloses a bright package one reflector wide. This together with poor seismic quality on other lines within the study area makes absolute identification of the pinch-out on all seismic lines difficult, especially where the loss of amplitude is very subtle, but nevertheless this interpretation is supported here as the pinch-out is observed on many lines (Figure 3.12: Figure 3.13). The Tartan Formation has not previously been depicted in well correlation panels.

The mudstones of the Hampden Formation and its equivalent, the Ashley Mudstone at Resolution-1 were deposited during the Eocene. Based on the biostratigraphy, these mudstones were deposited in deeper conditions than the underlying Moeraki Formation mudstones. A gradual fining upwards through the Hampden Formation is seen at all wells except Endeavour-1, and this is also suggestive of deepening conditions through the Eocene. The coarsening upwards sequence through the Hampden Formation at Endeavour1 can be attributed to local uplift at Endeavour -1 at that time. 


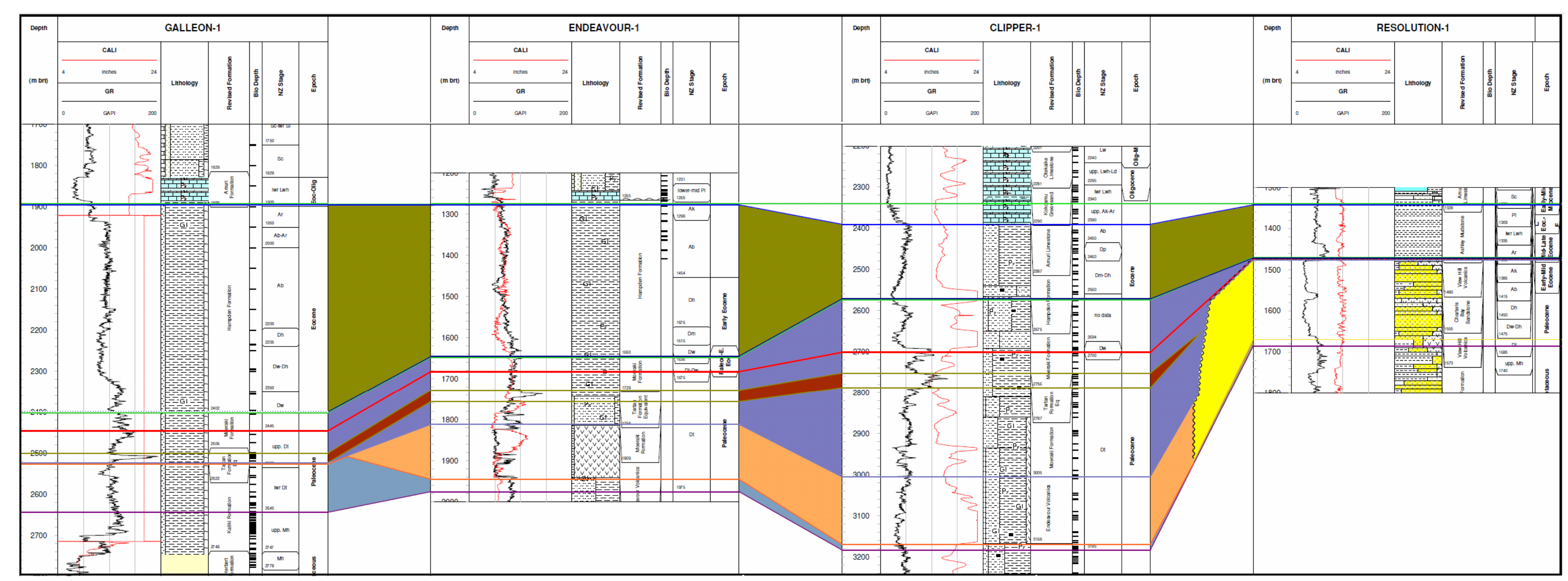

\begin{tabular}{lll|}
\hline Legend & & \\
\hline & Hampden Formation & Base Oligocene \\
\hline & Moeraki Formation & Top Paleocene \\
\hline & Tartan Formation Equivalent & \\
$\square$ & Endeavour Volcanics \\
$\square$ & Katiki Formation \\
\hline & Charteris Bay Sandstone \\
\hline & Conway Formation
\end{tabular}

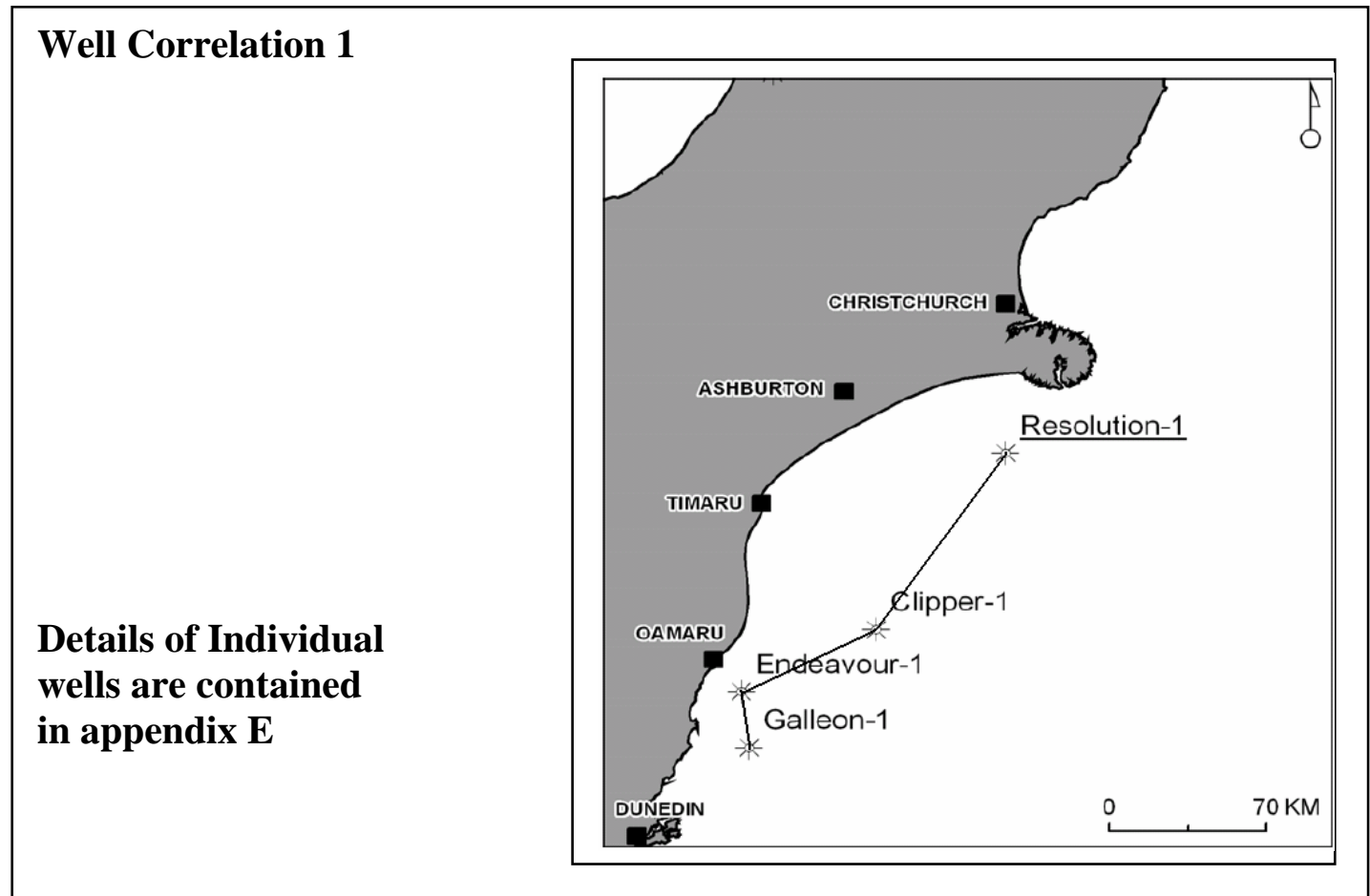

Figure 5.4: Well Correlation panel flattened on base Oligocene from Galleon-1 (Southwest) to Resolution-1 (Northeast). 


\subsection{Paleogeography and Synthesis}

\subsection{Introduction}

Paleogeographic maps were constructed for four time intervals within the Paleocene for the offshore Canterbury Basin; Early Teurian, Middle Teurian, Late Teurian and Latest Teurian. These maps were constructed from the insights gained from seismic interpretation, core lithofacies and wireline log correlation (Chapter 3 to Chapter 6), and provides an improved interpretation of the spatial and temporal evolution of the study area. A discussion on the inputs leading to the construction of the maps is followed by the presentation and discussion of these four paleogeographic maps, which provide a visual method of comparison with previous paleogeographic interpretations of the offshore Canterbury Basin.

\subsection{Inputs}

This section summarises the inputs for age, depositional environment and palaeobathymetric data. Stage boundaries were defined by revised biostratigraphic information (Section 5.4; Appendix B) and its correlated seismic horizon interpretation. Depositional environment constraints were developed from paleontological data, lithofacies, wireline log facies from wells and seismic facies (see Chapters 3 to 5). In particular seismic interpretation was critical for picking out the extent of the Charteris Bay Sandstone and the Tartan Formation, and to pick out the transition between the Charteris Bay Sandstone and the adjacent formations. The location of the shelf-slope break was constrained by paleontological data and the time structure maps and information from both of these were in agreement. The palaeobathymetric information available for the four wells Galleon-1, Endeavour-1, Clipper-1 and Resolution-1 is summarised in Section 6.2.1.

\subsubsection{Palaeobathymetry}

Palaeobathymetric information for the Paleocene and Eocene intervals, from the four wells drilled was reviewed and is presented here. All depths cited are measured depth (MD) from 
rotary table (RT) or kelly bushing (KB). Summary of palaeobathymetric information for the four wells are presented in Table 6.1 and Table 6.2. Due to the differences in nomenclature and interpretation of palaeobathymetry in different biostratigraphic reports, Figure 6.1 is presented to show the main marine paleoenvironmental divisions used in different reports of the four offshore wells.

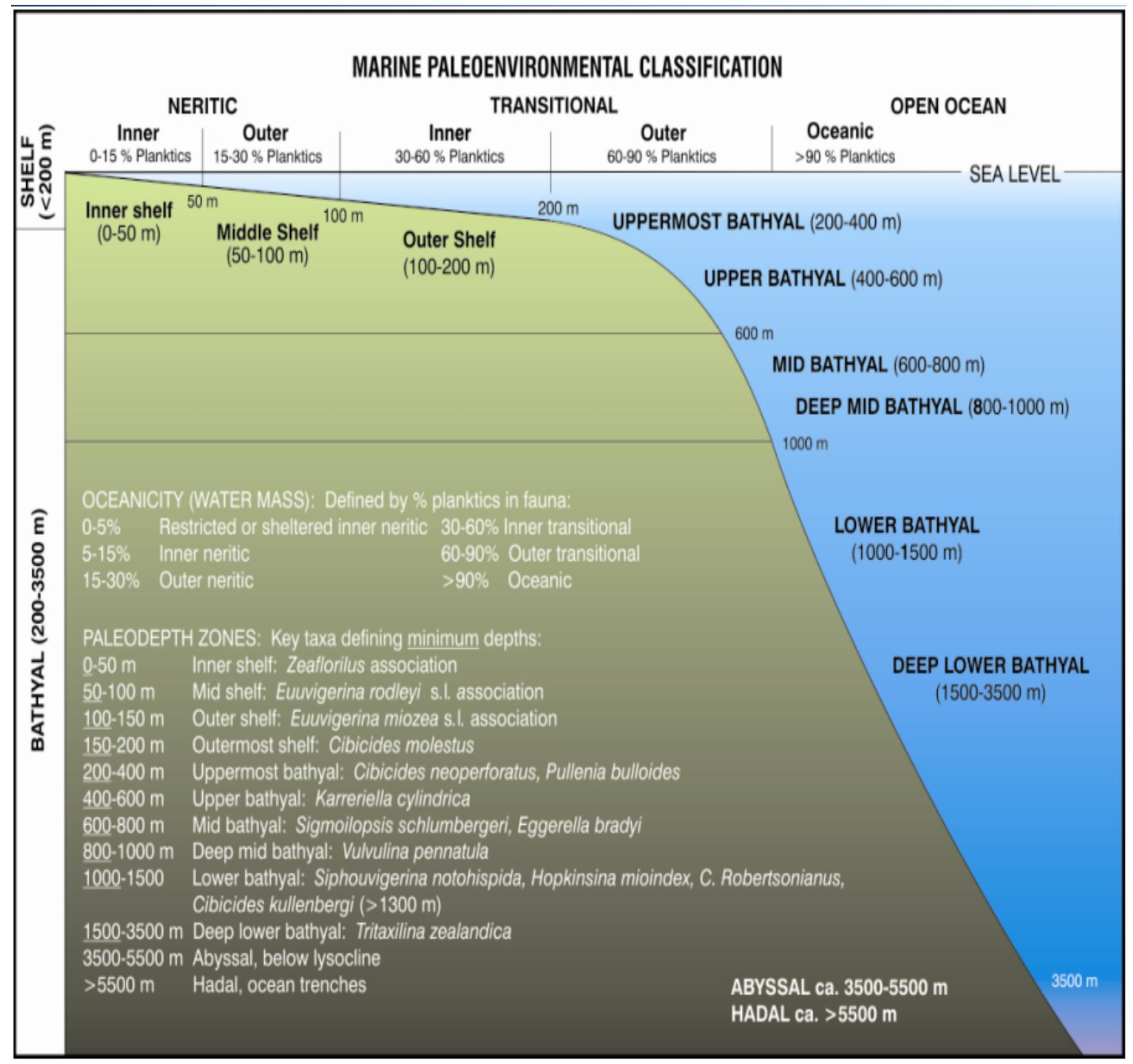

Figure 6.1: Marine paleoenvironmental classification scheme (after Hayward, 1986; figure courtesy of P. Schioler, GNS Science). 


\section{Eocene (55.5Ma-34.3Ma)}

Galleon-1 encountered Latest Eocene (Runangan) sediments from 1880m. The deep water foraminifera genus Nutallides present in sidewall core samples indicated a mid to outer shelf environment of deposition. Similar depths of deposition were recorded through the Mid to Late Eocene (Bortonian) (Jones et al., 1986). The Middle Eocene (Porangan) sediments were not positively identified or the interval was attenuated or unrepresented. Agllutinate dominated assemblages obtained from the Early to Middle Eocene (Heretaungan) aged sediments in this well indicated deposition in deep water, from restricted marine to upper bathyal settings. The Early Eocene (Mangaorapan) stage was not positively identified and an interval of sediment was grouped together with ages from Paleocene (Teurian) to Earliest Eocene (Waipawan) or even possibly till Early Eocene (Mangaorapan) (Jones et al., 1986). Palaeobathymetric settings obtained for the well for Late to Middle Eocene sediments were inner shelf to inner slope based on the presence of Bolivinopsis spectabilis interpreted to indicate a bathymetry of at least 500m (Jones et al., 1986). GNS (2009) interpreted the Eocene sediments to have been deposited in inner shelf to inner slope settings. The Mid to Late Eocene interval was not subsequently biostratigraphically revised. Based on the interpretations of palaeobathymetry from the reports listed above, an environment of deposition of inner shelf to inner slope was inferred for Eocene sediments at Galleon-1, in agreement with lithofacies descriptions showing predominantly very fine grained sediment deposited.

Endeavour-1 encountered a major unconformity where Latest Eocene (Runangan), Oligocene (Whaingaroan-Duntroonian-Waitakian), and Early Miocene (Otaian) aged sediments were missing (Schroeder, 1971). The sediments representing the Late Eocene (Kaiatan) to Early Eocene (Mangaorapan) were inferred to have been deposited on the slope and deeper based on comparison of the microfauna in the sediment to those found in the present (Schroeder, 1971). However, on comparison to the onshore Hampden section, and considering the development of shell bands there, depths of deposition indicated a shallower location (Schroeder, 1971). A revision of the biostratigraphy of the Cretaceous to Eocene section at Endeavour-1 (Pocknall, 1991; Raine, 1994) also recorded an inner shelf deposition for the Earliest Eocene (Waipawan) to Early to Middle Eocene (Heretaungan) aged sediments (Hampden Formation) based on the abundance of land derived palynomorphs and dinoflagellates. The palaeobathymetric 
information from the more recent reports discussed above inferred a shallower location of deposition of Mid to Late Eocene sediments and this agrees with the time structure maps which show that Endeavour-1 was farther away from the shelf-slope break with respect to Galleon-1 and Clipper-1.

The biostratigraphic inference for the Latest Eocene (Runangan) sediments encountered at the Clipper-1 well indicated a deposition in outer neritic environments on the basis of their foraminiferal assemblages (Crux, 1984). Below the Latest Eocene sediments, and until the top of the Paleocene, an outer neritic to upper bathyal environment of deposition was inferred based on the microfaunal assemblages containing Cyclammina grangeri, Cheilostomalla sp., Karreriella sp., Bolivinopsis compta and Quadrimorphina allomorphinoides (Crux, 1984). This interpretation suggests that the Clipper-1 well was in a fairly deep marine location with depths possibly reducing slightly through the Eocene.

The Resolution-1 well has been relatively understudied for its biostratigraphic information and interpretation of depositional environment. Latest Eocene (Runangan) sediments were encountered at $1330 \mathrm{~m}$ and an environment of deposition of outer shelf was inferred based on the presence of benthic foraminifera and sparse numbers of planktic foraminifera (Hornibrook et al., 1975). Shallow water deposition was indicated for Early to Middle Eocene (Heretaungan) sediments due to the decrease in calcareous foraminifera with depth and a sidewall core sample at that depth $(1462.5 \mathrm{~m})$ containing agglutinated foraminifera which indicated shallow deposition. The interval containing the Earliest Eocene (Waipawan) and the Teurian Stages (Paleocene) was inferred to have been deposited at very marginal marine settings based on shallow water assemblages of agglutinated foraminifera, and the coarse grained nature of the clastics encountered (Hornibrook et al., 1975). The interpretations given above suggest a deepening at the Resolution-1 well through the Eocene, with marginal marine environments during the Early Eocene and deeper environments during the Late Eocene.

\section{Paleocene (65Ma-55.5Ma)}

The Teurian Stage (Paleocene) at Galleon-1 was represented by sediments containing the foraminifera Globigerina pauciloculata and the depth of deposition inferred in the original 
biostratigraphic report was restricted marine to outer shelf to upper bathyal (Jones et al., 1986). The depth of deposition of the Late Teurian was re-interpreted by subsequent workers (Pocknall, 1991) to indicate a shallow water deposition in nearshore to paralic environments based on the presence of low diversity, agglutinated foraminifera. Teurian faunas consisted almost entirely of agglutinated foraminifera with abundance and diversity decreasing down hole. Such low diversity agglutinated foraminifera are typical of shallow water, near shore to paralic environments which are often characterised by subnormal to variable salinity. An up hole increase in the abundance and diversity of microfauna indicated greater marine influence and depths of deposition through the Paleocene sequence (Pocknall, 1991; Raine, 1994). For this study the palaeobathymetric assessment of Pocknall (1991) and Raine (1994) for Galleon1 was used in the construction of the paleogeographic maps as their studies were more recent and analysed this interval in greater detail using micro-paleontological and palynological analysis.

Deposition during the Teurian at Endeavour-1 was inferred to have taken place at shallower inner shelf depths with respect to deposition during the Teurian at Galleon-1 and Clipper-1. Within Endeavour-1, a thin, extremely hard and glauconitic sandstone interval was seen below the Tartan Formation and was recorded during examination of the sidewall cores (Sandstone 2 facies, Section 4.2.5). This would suggest a shallow water environment and is also indicated by many shallow water assemblages recorded over this interval (e.g., Haplophragmoides spp. and Trochammina spp.) (Schroeder, 1971). A revision of the biostratigraphy of the Cretaceous to Eocene section at Endeavour-1 (Pocknall, 1991), also concluded that the Teurian experienced inner shelf deposition, but within the interval of the KT boundary, extreme inner-shelf to nearshore conditions were inferred based on the presence of abundant dinoflagellates, lack of benthic foraminifera and the presence of Haplophragmoides spp. A subsequent review of the Cretaceous to Eocene section at Endeavour-1 by Raine (1993) concluded that the interval from $1734.3 \mathrm{~m}$ to $1968.9 \mathrm{~m}$ consisting of Teurian aged sediments and representing the Moeraki Formation was deposited in inner shelf environments. Near shore conditions were also indicated by low diversity foraminiferal assemblages dominated by agglutinated foraminifera present in the Teurian aged interval (Raine, 1994). For this study the palaeobathymetric assessment by Pocknall (1991) 
and Raine (1994) for Endeavour-1, suggesting inner shelf deposition during the Teurian, was used in the construction of the paleogeographic maps.

The depth of deposition inferred for the Clipper-1 well during the Teurian in the original biostratigraphic assessment was an outer neritic to bathyal environment of deposition, based on the presence of agglutinated foraminiferal assemblages and marine dinoflagellate cysts. However, Wilson (1985) used the predominance of pollen and spores and the prevalence of cavate cysts in core and cuttings samples from the Teurian interval to indicate a near shore, probably shallow water deposition. Shallow water assemblages were seen throughout the Teurian based on Wilson's (1985) analysis. Raine (1994) concluded a near shore deposition for Teurian sediments based on the likely absence of calcareous planktic or benthic foraminifera, the absence of deep water taxa and the shallow water deposition of the immediately underlying Katiki Formation. The relative abundance of miospores in palynological samples, and the prevalence of dinoflagellate cysts also indicated nearshore environments (Raine, 1994). They also noted that the sparseness of faunas suggested environmental stress, possibly due to turbidity or abnormal salinity. For this study, the Teurian sediments at Clipper-1 were interpreted to have been deposited in near shore settings, based on Wilson's (1985) and Raine's (1994) assessment.

The interval containing the Earliest Eocene (Waipawan) and Paleocene (Teurian) sediments at Resolution-1 was inferred to have been deposited at very marginal marine sites based on shallow water assemblages of agglutinated foraminifera, and the coarse grained nature of the clastics encountered (Hornibrook et al., 1975). However, the lower part of the Charteris Bay Sandstone yielded no foraminifera and hence in the original biostratigraphic assessment, this interval was interpreted to have been deposited in very marginally marine or non marine environments. A review of the palaeobathymetric information by GNS (2009) also concluded a marginal marine environment of deposition, due to the presence of dinoflagellate specimens, and therefore deposition here was taken to be at marginal marine settings in this study. 


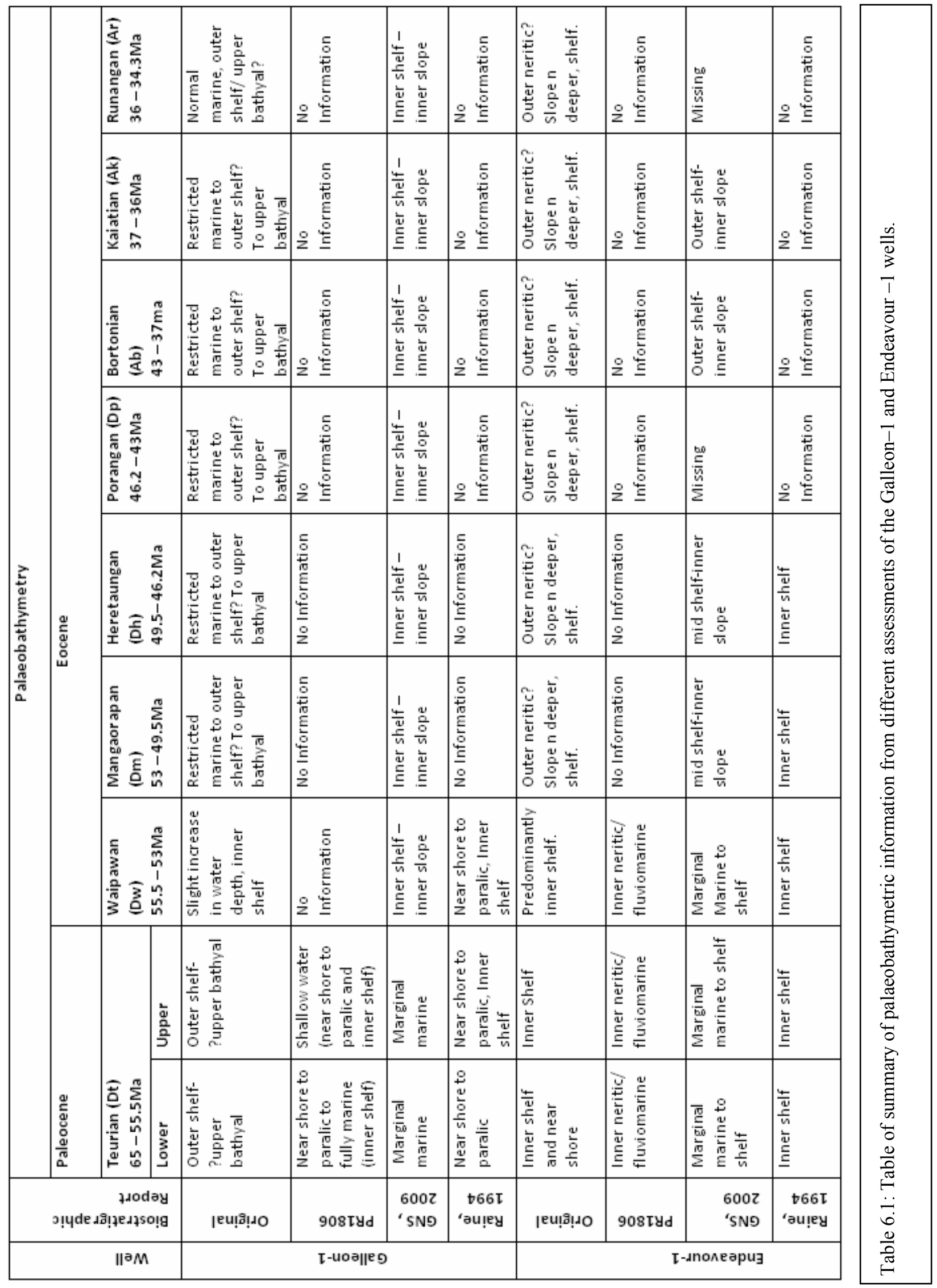




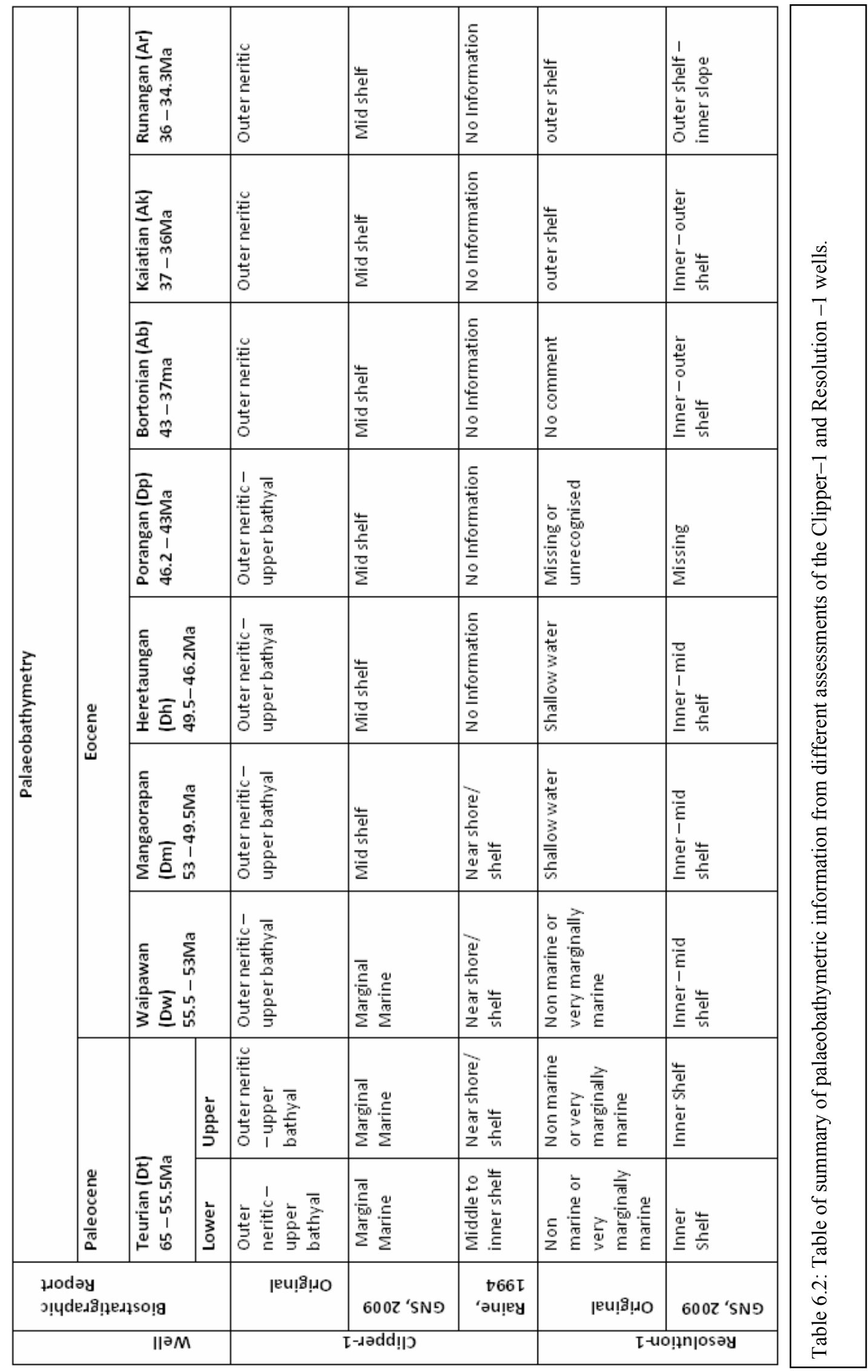




\subsection{Synthesis}

The paleogeographic maps are discussed in this section. The legend for the paleogeographic maps is presented in Figure 6.2.

\section{Bathymetry \\ Facies

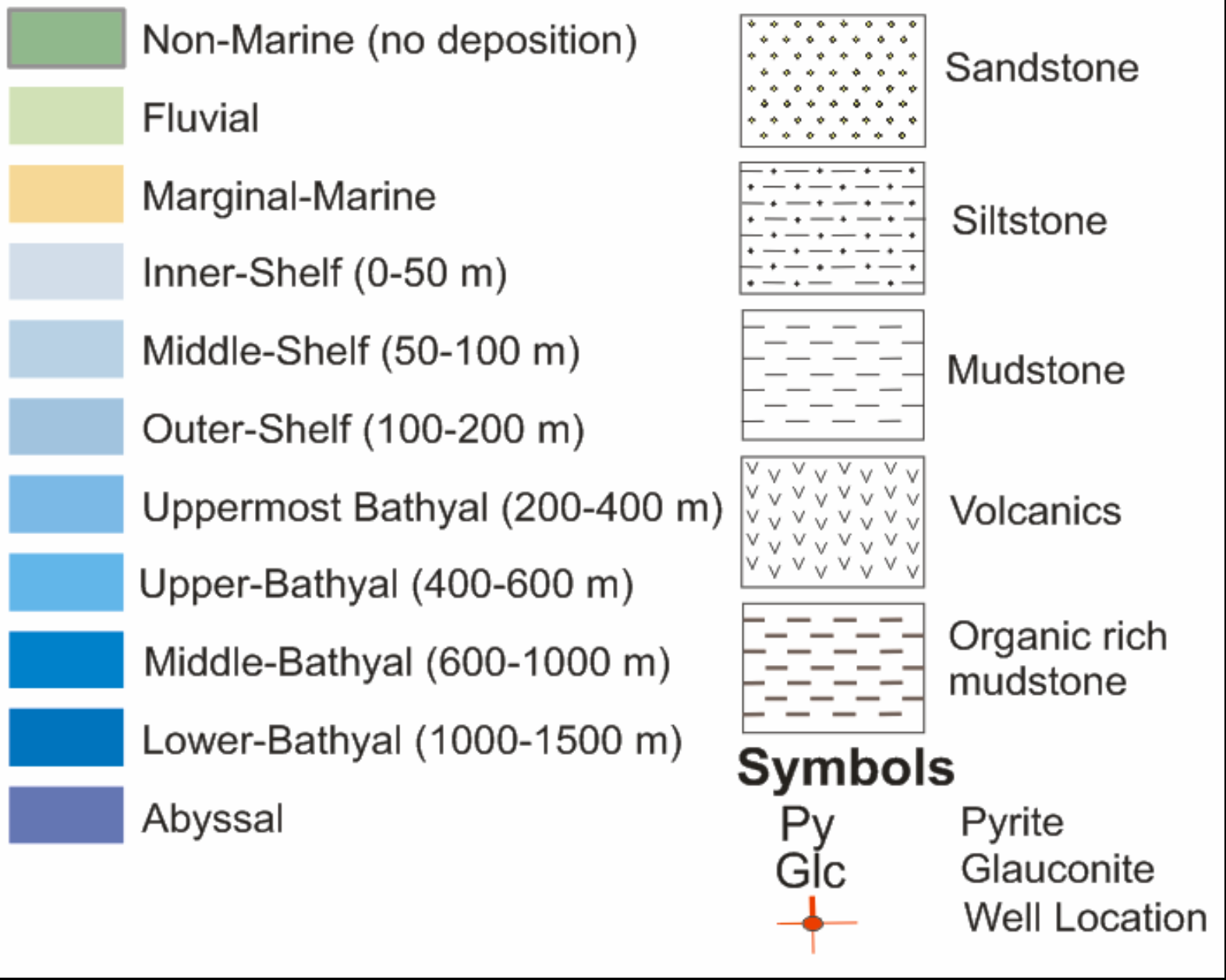

Figure 6.2: Legend for the paleogeographic maps (Figure 6.3 to Figure 6.6).

\subsubsection{Early Teurian}

During the Early Teurian (Figure 6.3), the offshore Canterbury Basin was submerged with water depths increasing towards the southeast. The four wells were located in shelf environments at this time, with Resolution-1 at a relatively higher location and situated much farther landward from the shelf-slope break and Clipper-1 located nearest to the shelf-slope break. The generally coarser nature of sediments at the base of the Teurian interval in 
Resolution-1 attests to deposition being in slightly higher energy conditions than the other three wells. In the northeast and towards Resolution-1, the silty Conway Formation was being deposited, and south of this, the mudstones of the Katiki Formation were being deposited. The change from the Conway Formation to the Katiki Formation mudstones at the Earliest Paleocene level was picked out from seismic interpretation where the Charteris Bay Sandstone thins and transitions to the Moeraki Formation mudstones. Some glauconite grains observed in sidewall core samples of the Moeraki Formation also indicate that deposition was slow. 


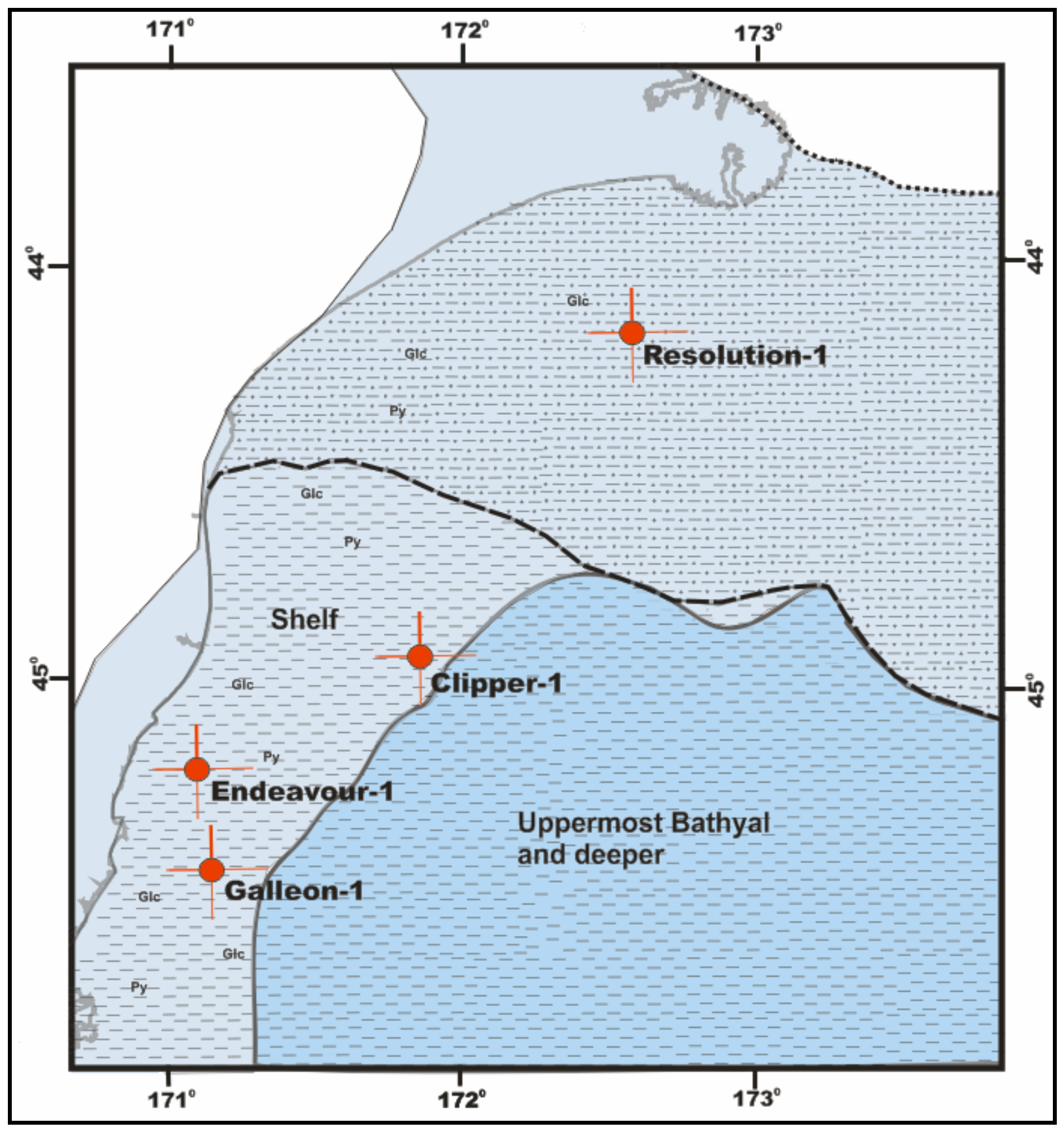

Figure 6.3: Early Teurian paleogeographic interpretation of the study area. Thick dashed line represents inferred change from Conway Formation in the north to the Katiki Formation in the south. Colours and symbols are as per legend in Figure 6.2.

\subsubsection{Middle Teurian}

Deposition during the Middle Teurian was again at marine settings over the entire basin with water depths increasing towards the southeast (Figure 6.4). At this time from Early to possibly Middle Teurian (Paleocene), the Charteris Bay Sandstone was being deposited in relatively 
high energy conditions in the north of the basin. Towards the south the mudstones of the Moeraki Formation were being deposited. The Endeavour Volcanics were also being deposited with sediments towards the south. The Endeavour Volcanics were encountered at Endeavour-1 and Clipper-1 in Paleocene age sediments. Although the volcanics are possibly intrusive at Endeavour based on the baking of the mudstones above the volcanics (Haskell, 1989a), the volcanics encountered at Clipper-1 consisted of volcaniclastic debris mixed in with mudstones which indicates the volcanics were sourced elsewhere. The transition from the Charteris Bay Sandstone to the mudstones of the Moeraki Formation was constrained by seismic interpretation and is shown in Figure 6.4 (thick black dashed line). The Charteris Bay Sandstone has been dated as being mostly Early Teurian (GNS, 2009), and deposition of the sands appears to have resulted in a topographic high. The Charteris Bay Sandstone was then onlapped by the Moeraki Formation mudstones. The deposition of the Charteris Bay Sandstone would indicate a relative regression taking place in the basin, which is consistent with work done in the adjacent Great South Basin by Schioler et al., (2009), which inferred a regression throughout the Paleocene. However, in contrast to the work by Schioler et al., (2009), a relative sea level rise is inferred in the Canterbury Basin from Middle(?) to Late Paleocene as indicated by the apparent onlap of the Moeraki Formation mudstones on to the Charteris Bay Sandstone. 


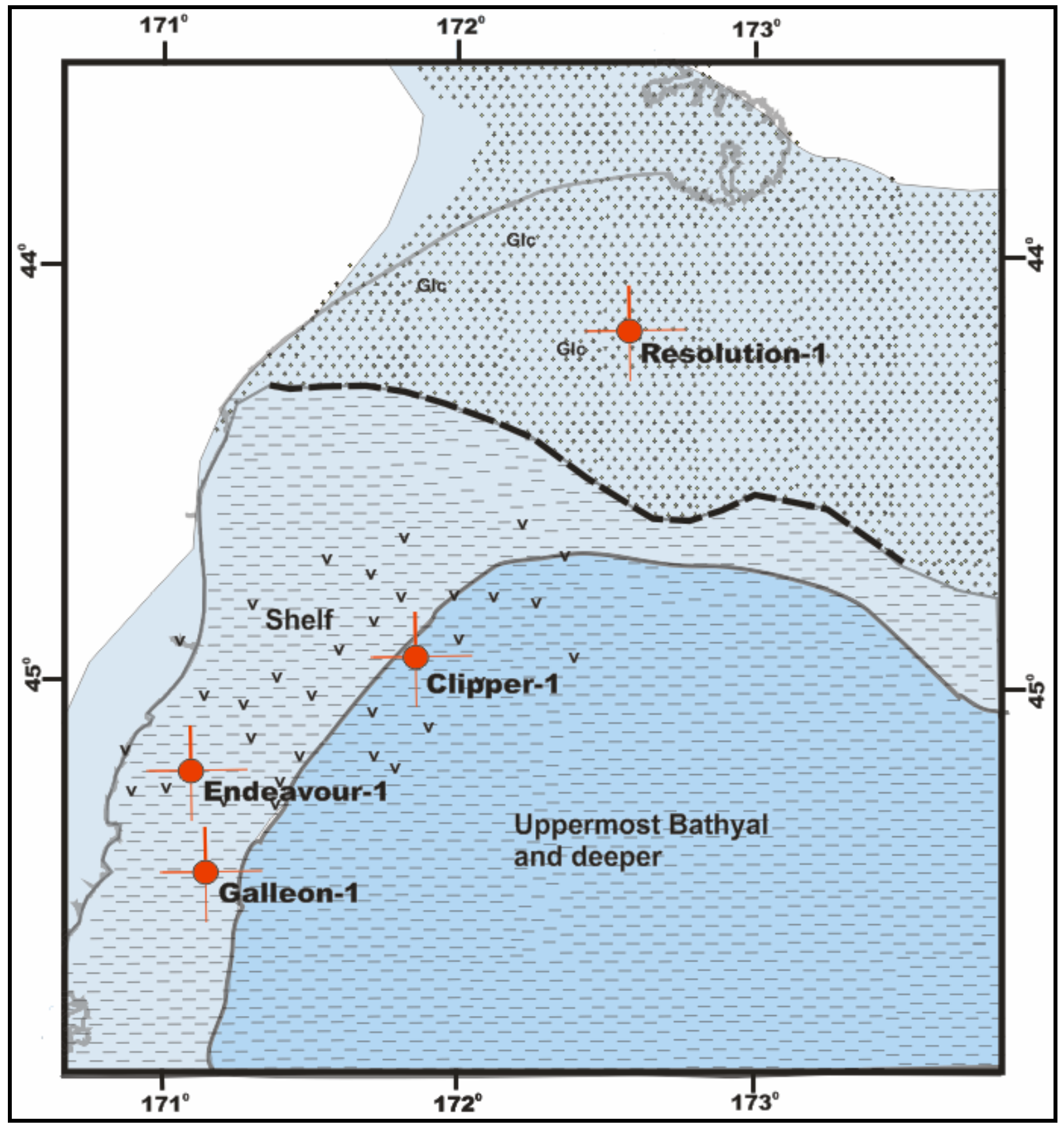

Figure 6.4: Middle Teurian paleogeographic interpretation of the study area. Thick black dashed line represents the transition from the Charteris Bay Sandstone to the Moeraki Formation. Colours and symbols are as per legend in Figure 6.2.

\subsubsection{Late Teurian}

During the Late Teurian (Late Paleocene), the organic rich Tartan Formation was being deposited over a large part of the offshore Canterbury Basin (Figure 6.5). The high organic richness of the Tartan Formation in relation to the relatively low organic richness of adjacent 
formations indicates a profound change in the conditions under which the Tartan Formation was deposited. The large terrestrial contribution to organic matter present within the Tartan Formation (Meadows, 2009; Schioler and Roncaglia, 2008) points to a lowering of relative sea level. The Tartan Formation was deposited in the south and central parts of the study area and is absent towards the north and at Resolution-1. At this time deposition of the Charteris Bay Sandstone had ceased towards the north of the area and towards Resolution-1. There are no indicators of Late Paleocene age at the Resolution-1 well, and therefore it appears sedimentation was very slow, had ceased, or any Late Paleocene sediments were later eroded from the northeast of the study area. The Tartan Formation is also observed from seismic to pinch-out towards the north, between Clipper-1 and Resolution-1 and this is shown in Figure 6.5 (thick black dashed line).

From the information within the Canterbury Basin wells at which the Tartan Formation is present, current biostratigraphic information indicates a Late Teurian age for the formation. However, no information is available from the microfauna to indicate a change in depositional conditions with respect to the enclosing formations. A thin sandstone layer encountered at Endeavour-1 20m below the Tartan Formation Equivalent would indicate a turn to deposition at higher energy conditions just before deposition of the Tartan Formation at that area. A lowering of sea level at the time of deposition of the Tartan Formation would also account for the apparent absence of Late Paleocene sediments at the Resolution-1 well and would agree with results obtained from the adjacent Great South Basin by Schioler et al., (2009). 


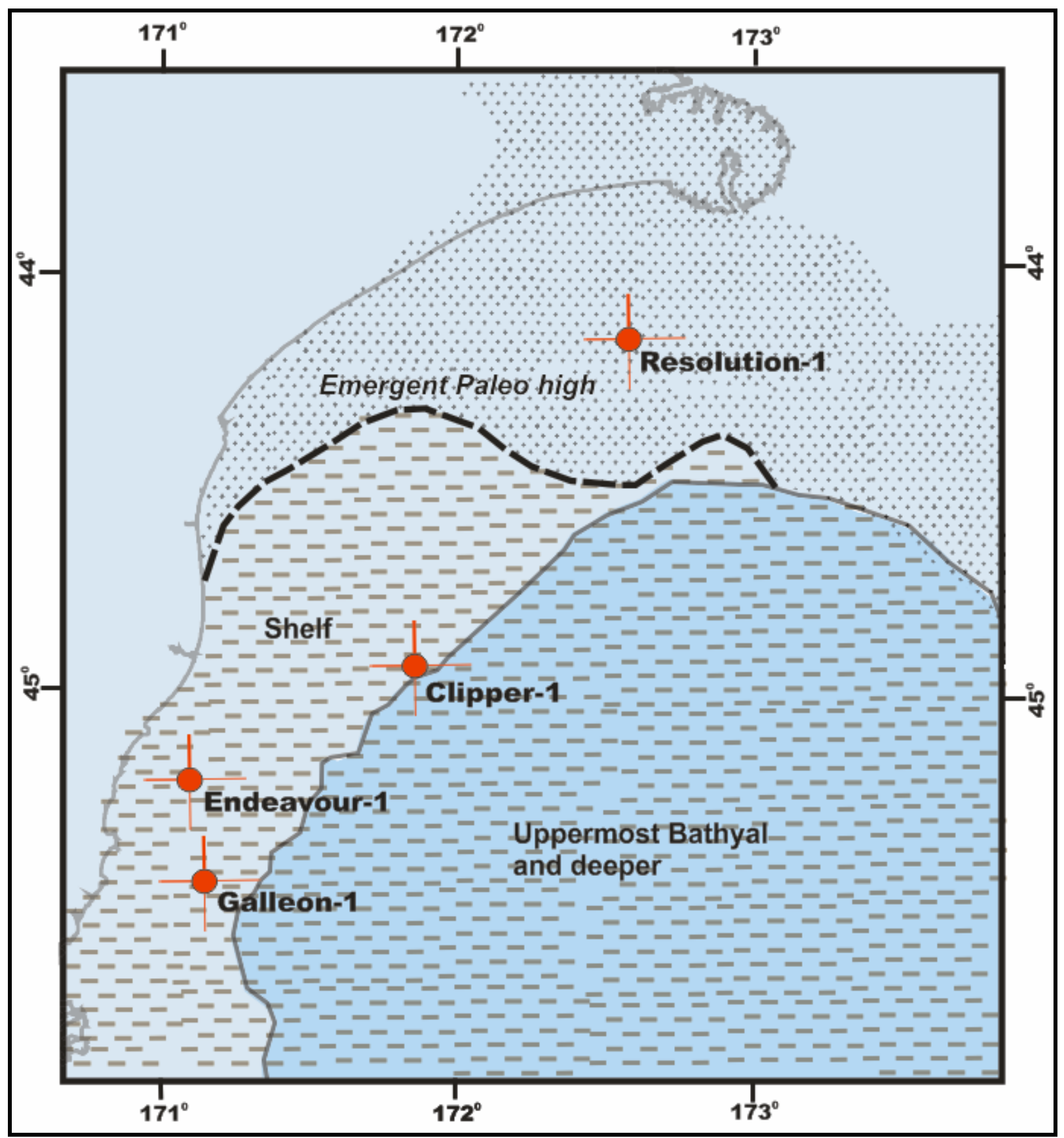

Figure 6.5: Late Teurian paleogeographic interpretation of the study area. Thick black dashed line represents the interpreted northward pinch-out of the Tartan Formation. Colours and symbols are as per legend in Figure 6.2.

\subsubsection{Latest Teurian}

By the Latest Teurian (Figure 6.6) there was widespread deposition of mudstones over the southern offshore Canterbury Basin. Towards the south of the area, the mudstones of the 
Moeraki Formation were being deposited above the organic rich mudstones of the Tartan Formation. However, there are no definite indicators of Late Teurian sediments at the Resolution-1 well. Revised biostratigraphic work undertaken by GNS Science (Raine, J.I., pers. comm.) suggests that the Teurian interval at Resolution-1 does not contain any Late Teurian deposits. The dinoflagellate Palaeoperidinium pyrophorum at $1555 \mathrm{~m}, 1595 \mathrm{~m}$, and $1635 \mathrm{~m}$ indicates Early Teurian or a slightly older age and the miospore Nothofagidites waipawaensis at $1478 \mathrm{~m}$ (near the top of the Paleocene sediments) also suggests an Early Teurian age. A foraminiferal assemblage from a sidewall core sample at $1462.5 \mathrm{~m}$ is of undifferentiated Teurian age. Earliest Eocene (Waipawan) or younger strata occur at $1462.5 \mathrm{~m}$ and above. This area during the Latest Teurian either witnessed a sediment bypass, extremely slow sedimentation, or erosion. 


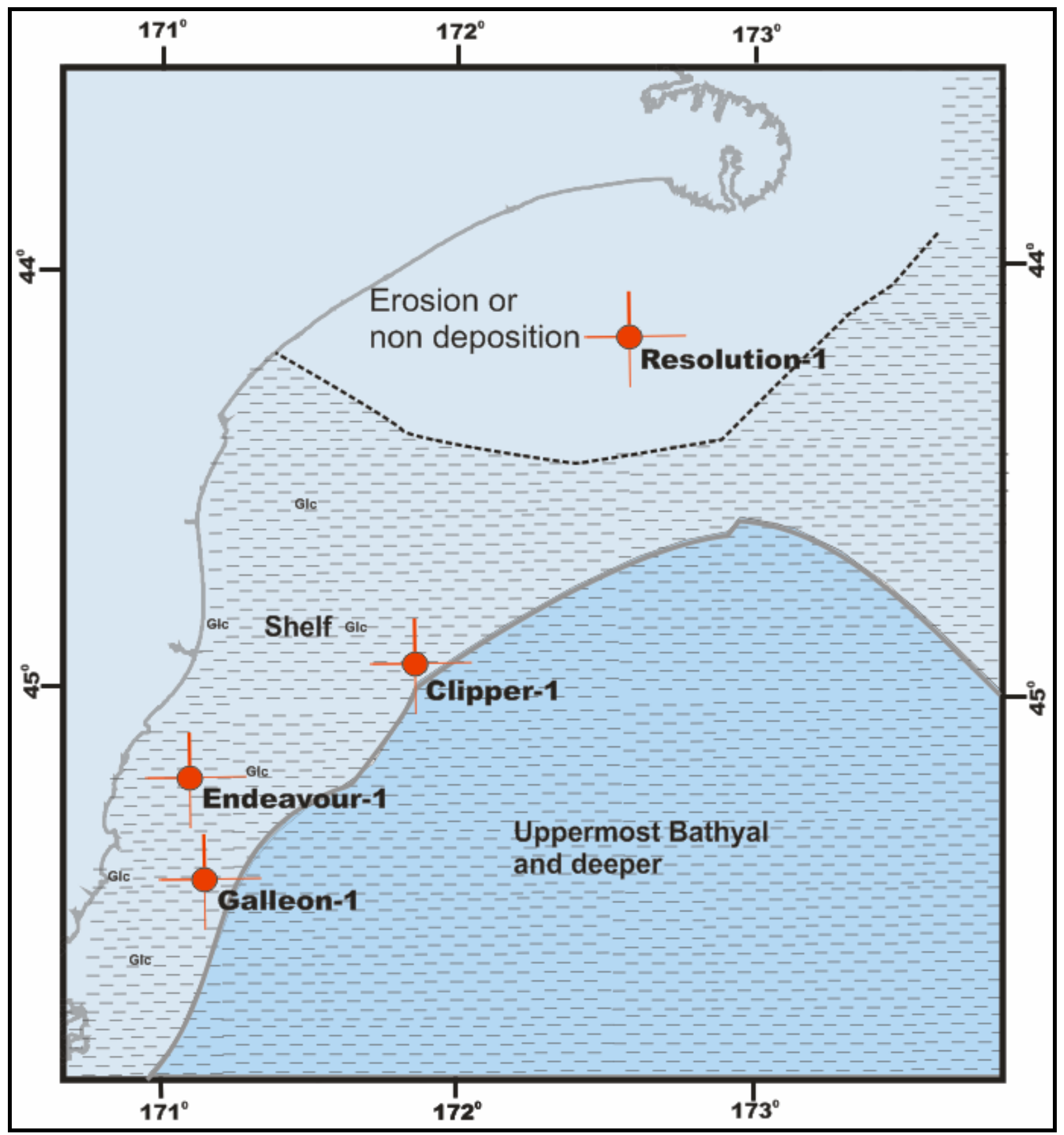

Figure 6.6: Latest Teurian paleogeographic interpretation of the study area. Colours and symbols are as per legend in Figure 6.2.

Previous paleogeographic maps of the base Paleocene (Cretaceous-Tertiary boundary map of Field and Browne, 1989a) shows the Galleon-1 and Clipper-1 wells being at bathyal depths. However, updated biostratigraphic information has inferred that the basal Paleocene sediments were deposited in shelf settings, and mostly in inner shelf settings and seismic interpretation also corroborates this interpretation. Moreover, the basal paleocene sediments around the 
Resolution-1 well were shown to be sandstones in the original well completion report, but revised biostratigraphic information (GNS, 2009), well correlation and seismic interpretation (this study) has shown that the earliest Paleocene sediments were the siltstones of the Conway Formation. This study presents the first paleogeographic maps for the Middle Paleocene incorporating the Charteris Bay Sandstone, and the Late Paleocene incorporating the Tartan Formation. Furthermore, this study has shown the extent of the Tartan Formation over the study area deposited during the Late Paleocene, and shows that the Tartan Formation is a distinct layer of organic rich mudstone within the adjacent Moeraki and Katiki Formations.

\subsection{Summary}

This study has developed an improved understanding of the Paleocene interval in offshore Canterbury Basin and has presented new paleogeographic maps. Key advances in understanding the paleogeography include: 1) locating the shelf-slope break from well-data with corroboration from seismic mapping and 2) locating the lateral extents of the Tartan Formation and Charteris Bay Sandstone by identification and mapping of key seismic facies with corroboration from well data. From this it is seen that during the Earliest Teurian, mudstones were deposited in the southern parts of the offshore Canterbury Basin and siltstones to the north. A relative sea level fall is inferred for deposition of the Charteris Bay Sandstone from Early to Middle(?) Teurian in the north. Following this, there was a relative sea level rise causing the mudstones of the Moeraki Formation to onlap against the southern extent of the Charteris Bay Sandstone. From Middle to Late Teurian there was a relative regression culminating with the deposition of the organic rich Tartan Formation over the central and southern areas of the offshore Canterbury Basin, and sediment bypass or erosion at the north of the study area. 


\subsection{Conclusions}

\subsection{Project achievements}

This project mapped and investigated the Paleocene interval in the offshore Canterbury Basin, New Zealand. This was achieved through the analysis of seismic data, wireline log data and core facies of the Paleocene stratigraphic interval. In particular, this study has:

- Mapped and tied three chronostratigraphic seismic horizons (base Paleocene, top Paleocene and base Oligocene) to the four offshore wells Galleon-1, Endeavour-1, Clipper-1 and Resolution-1 using revised information for formation tops and chronostratigraphic markers. The seismic grid within the study area was interpreted within this revised chronostratigraphic framework and seismic facies of the different units were recorded and analysed. Consequently, the seismic interpretation is better constrained and better shows the development of the Canterbury Basin through the Paleocene.

- Identified and mapped angular erosional truncations below the base Oligocene reflector, adding further examples of very rare angular truncation observed at this level. This study also confirms the previous hypothesis that non-regional erosion was taking place in deep water presumably due to strong bottom water currents, and that this erosional event was not due to a major lowering of sea level as proposed by some workers. This erosion was local, which further supports erosion due to strong currents.

- Mapped and defined the north-eastern limit of the Tartan Formation and its development and thickness. This study has shown that the Tartan Formation is present in the central and southern areas of the offshore Canterbury Basin, and also extends into the deeper waters of the offshore Canterbury Basin. The Tartan Formation is seen to be consistently thin and to have a relatively greater thickness within the central part of the basin, around Clipper-1. Variations in seismic amplitude of the formation have 
been identified which might possibly be related to changes in organic content. The identification and mapping of the organic rich Tartan Formation also suggests a brief fall in sea-level during its deposition.

- Mapped and defined the southern extent of the Charteris Bay Sandstone and its thickness within the offshore Canterbury Basin within the study area. The Charteris Bay Sandstone is seen to wedge out towards the northwest of the study area, between Resolution-1 and Clipper-1 and to have its greatest thickness developed towards the centre of the basin, just before the south to south-westward location (of Resolution-1) where it wedges out. A relatively thick section of the sandstones was also identified towards the north and northwest of Resolution-1 where a thick section of the sandstones are inferred to be present onshore based on the distribution of sands in this study.

- Mapped the transition from the Charteris Bay Sandstone to the Moeraki Formation mudstones from the northeast to the southwest within the offshore Canterbury Basin. This transition in subtle and complex, and shows that the Charteris Bay Sandstone is older than the Moeraki Formation and that deposition of the Charteris Bay Sandstone resulted in a high. These sandstones were subsequently onlapped by the Moeraki Formation mudstones and the impedance contrast is captured well on many seismic lines.

- Developed and presented an improved well correlation panel between the four wells Galleon-1, Endeavour-1, Clipper-1 and Resolution-1 for the Paleocene and Eocene. This well correlation panel incorporates the Tartan Formation which previously has not been shown on well correlations done in the Canterbury Basin. The well correlation utilises previous revised biostratigraphic studies, and a review of lithologies and wireline logs, sidewall core descriptions and well data done in this study.

- Constructed and presented revised paleogeographic maps for the Early Teurian, Middle Teurian, Late Teurian and Latest Teurian Stages. These paleogeographic maps 
incorporate the new insights gained from this study and show the development of the Canterbury Basin through the Paleocene. New features in these paleogeographic maps include the distribution of the Conway Formation and the Katiki Formation during the Early Paleocene, the development and extent of the Charteris Bay Sandstone from Early to possibly Middle Paleocene, the paleogeography during the Late Paleocene during the deposition of the organic rich Tartan Formation in the central and southern parts of the basin, and deposition in the basin during the Latest Teurian, which involved deposition of mudstones to the south and possible erosion or non-deposition in the north.

Consequently, the understanding of the temporal and spatial development of the Paleocene sediments within the offshore Canterbury Basin has been improved and better constrained through this multi disciplinary study.

\subsection{Implications for hydrocarbon prospectivity}

The Paleocene interval of Canterbury Basin contains potential source and reservoir rock intervals (Tartan Formation and Charteris Bay Sandstone respectively).

Confirmed gas-condensate shows were recorded in two offshore wells, Clipper-1 and Galleon-1. In Clipper-1 the shows were in Mid-Cretaceous sandstone interbeds (4084$4134 \mathrm{~m} \mathrm{bsf}$ ), and a condensate sample was recovered from a repeat formation test (RFT, $4096.5 \mathrm{~m}$ bsf) (Hawkes \& Mound 1984). In Galleon-1 gas-condensate was present in a massive Late Cretaceous sandstone unit. The well flowed up to $2240 \mathrm{bbl} / \mathrm{day}$ condensate and up to $30 \times 10^{6} \mathrm{~m}^{3} /$ day of gas (Wilson 1985). Further condensate shows were present in sandstones at greater depth (Wilson, 1985). Both these intervals were within the Late Cretaceous sediments. Some unconfirmed reports of hydrocarbon seeps have also been noted in onshore Canterbury (Field \& Browne, 1989a). Collectively, these reports show that the Canterbury Basin has working petroleum systems. 
The Tartan Formation and it equivalent, the Waipawa Black Shale have been the subject of many studies mainly due to its potential to source hydrocarbons (Hollis et al., 2006; Jackson, 1982; Rogers et al., 1999; Schiøler et al., 2009). Studies of the Tartan Formation in the Canterbury Basin and the Great South Basin show that the formation is an excellent source rock with an average $\mathrm{HI}$ of c. $300 \mathrm{~kg} \mathrm{HC} / \mathrm{t}$ Corg (i.e., $300 \mathrm{~kg}$ hydrocarbons per tonne of organic carbon) suggesting mixed oil and gas potential, as also indicated by GOGI values of 0.3 for samples from Clipper-1, Galleon-1, and Toroa-1 (Gibbons and Fry, 1986; Gibbons and Jackson, 1980; Gibbons and Jackson, 1984; Jackson, 1982; Killops et al., 1997). A sample of the Tartan Formation observed from the sidewall core at Galleon-1 at $2519.5 \mathrm{~m}$ had an unusually oily odour which could indicate some level of oil expulsion has occurred at that level. Schioler et al., (2009) analysed the bulk geochemistry and petroleum potential of the Tartan Formation in the adjacent Great South Basin and found that while the Tartan Formation had high Total Organic Carbon (TOC) contents, the Hydrogen Index (HI) values averaged 203 $\mathrm{mg} \mathrm{HC} / \mathrm{g}$ TOC, with a range from 157 to $268 \mathrm{mg} \mathrm{HC} / \mathrm{g}$ TOC indicating mostly gas and some mixed oil and gas expulsion potential. A study by Sykes and Funnell (2002) for source potential of the Tartan Formation Equivalent found a TOC range from 0.8-11.7\%, averaging $7.2 \%$, S2 values of $1.5-28.3 \%$ averaging $17.9 \%$ and with $\mathrm{HI}$ values ranging from $175-401 \mathrm{mg}$ $\mathrm{HC} / \mathrm{g} \mathrm{C}_{\text {org. }}$. These values show that the Tartan Formation encountered within the wells in the Canterbury Bain has excellent source potential for oil and gas. However, the contribution of the Tartan Formation to oil and gas generation in the Canterbury Basin seems to depend on its distribution in the deeper parts of the basins, as it is has been found to be immature in exploration wells where encountered (Gibbons and Fry, 1986; Gibbons and Jackson, 1984; Jackson, 1982; Killops et al., 1997; Sykes, 2002). The Tartan Formation is relatively thin within the Canterbury Basin and this affects its source potential. Seismic mapping over a part of the offshore area of the basin in this study has found no evidence to suggest a thicker interval in other parts of the basin. In general it is seen to be consistently thin across the study area. The Tartan Formation however shows changes in the amplitude of its seismic response and gamma ray response, which might be related to changes in organic matter content. Greater organic content within the Tartan Formation would increase its potential as a source rock and more so if the Tartan Formation is buried at greater depths in the more offshore regions of the Canterbury Basin that are outside the study area. 
Although the identification of hydrocarbon prospects within the study area was beyond the scope of this project, the insights gained have led to a better understanding of the distribution of the Charteris Bay Sandstone within the Canterbury Basin. The Charteris Bay Sandstone has excellent potential as a reservoir interval with log derived porosities measured at the Resolution-1 well in the range of 35\%-45\% (Milne, 1975). The majority of this sand observed in the well was clean, but pyritic/glauconitic zones were inferred to be present on the basis of a reduction in sonic transit time relating to a reduction in porosity, and high gamma ray response. This study has shown that a sufficient thickness of the sands is present in the study area ( 200ms maximum thickness). These sands are also inferred to pass north and north-westward of Resolution-1 and onto the onshore parts of the basin. Stratigraphic trapping opportunities within the Charteris Bay Sandstone are a definite possibility, especially at the wedge out of the sands southwest of Resolution-1 where there is complex onlapping of the Charteris Bay Sandstone by the mudstones of the Moeraki Formation.

\subsection{Future work}

The study of the Paleocene interval in this project has identified several issues relating to the offshore Canterbury Basin which can be explored further. Mapping the Tartan Formation into the deeper parts of the Canterbury Basin would lead to a better understanding of the depth of burial of the Tartan Formation there, whether the formation has potentially reached maturity in the deeper parts of the basin, and whether it has a greater thickness there. This information can potentially upgrade the source rock status of the Tartan Formation and increase the prospectivity of the offshore Canterbury Basin.

Further detailed mapping of the Charteris Bay Sandstone in the other parts of the northern Canterbury Basin has the potential to locate closures associated with these sandstones, which could potentially lead to hydrocarbon discoveries. More detailed seismic mapping using 3D seismic data also has the potential to locate structural and stratigraphic closures with greater certainty. The Charteris Bay Sandstone was believed to have been hydrodynamically flushed at Resolution-1 (Milne, 1975). If the sands did contain hydrocarbons, they have migrated up 
dip and therefore locating structural and stratigraphic closures up dip of Resolution-1 would lead to a possibility of these structures hosting hydrocarbons. Further geophysical studies over these closures could indicate whether oil and gas is present below.

A period of non deposition, erosion or sediment bypass is inferred to have taken place around the Resolution-1 well from the Late Paleocene to Earliest Eocene in this study. Further high resolution biostratigraphic work at the Clipper-1 and Resolution-1 wells may reveal the age differences of Paleocene sediments between the wells and show in greater detail the stratigraphic relationship between the two wells. For example, the Moeraki Formation mudstones are interpreted from seismic data in this study to onlap over the Charteris Bay Sandstone. This interpretation suggests that the Charteris Bay Sandstone is younger than the Moeraki Formation. Further detailed biostratigraphic work at Resolution-1 may confirm this and also establish the presence or the absence of an unconformity which would indicate possible removal of Late Paleocene sediments from the well, and could further support a regression in the Late Paleocene, during deposition of the Tartan Formation. 


\section{References}

Allen, P. A., and J. R. Allen, 2005, Basin analysis: principles and applications. Malden, MA, Blackwell Pub.

Anderton, P.W., N. H. Holloway, J. C. Engstrom, H. M. Ahmad, and B. Chong, 1982, Geological/geophysical exploration report. Evaluation of geology and hydrocarbon potential of the Great South and Campbell Basins: Petroleum Report Series 828, Unpublished Petroleum Report, Ministry of Economic Development, New Zealand.

Asquith, G., and C. Gibson, 1982, Basic well log analysis for geologists: American Association of Petroleum Geologists.

Ballance, P. F., 1992, Sedimentary Basins of the South Pacific: many questions, fewer answers: 1991 NZ Oil Expl Conf Proc 255-260.

Bennett, D., R. Brand, D. Francis, S. Langdale, C. Mills, B. Morris, and X. Tian, 2000, Preliminary results of exploration in the onshore Canterbury Basin. In: 2000 New Zealand Oil Exploration Conference Proceedings, Ministry of Economic Development, Wellington.

BP Shell Todd, 1984, Interpretation and prospectivity of PPL 38203, Canterbury Basin, New Zealand: Petroleum Report Series PR 1046, Unpublished Petroleum Report, Ministry of Economic Development, New Zealand.

Brown Jr, L. F., and W. L. Fisher, 1980, Principles of seismic stratigraphic interpretation: AAPG Memoir, v. 26, p. 213-248.

Browne, G., and B. Field, 1985, The lithostratigraphy of Late Cretaceous to Early Pleistocene rocks of northern Canterbury, New Zealand: New Zealand Geological Survey Record, v. 6, p. 63.

Burwood, R., 1976, Canterbury Basin-NZ degree of organic diagenesis and source rock potential in well Resolution-1: Petroleum Report Series PR 666, Unpublished Petroleum Report, Ministry of Economic Development, New Zealand.

Cant, D. J., 1984, Subsurface facies analysis. In: Walker, R.J. ed. Facies models. Geological Association of Canada, 297-310.

Carter, R. M., J. K. Lindqvist, and R. J. Norris, 1982, Oligocene unconformities and nodular phosphate-hardground horizons in western Southland and northern West Coast: Journal Royal Society of New Zealand, v. 12, p. 11-46.

Carter, R. M., 1985, The Mid-Oligocene Marshall Paraconformity, New Zealand:

Coincidence with Global Eustatic Sea-Level Fall or Rise?: The Journal of Geology, v. 93, p. 359-371. 
Carter, R. M., 1988, Plate boundary tectonics, global sea-level changes and the development of the eastern South Island continental margin, New Zealand, Southwest Pacific: Marine and Petroleum Geology, v. 5, p. 90-107.

Catuneanu, O., 2002, Sequence stratigraphy of clastic systems: concepts, merits, and pitfalls: Journal of African Earth Sciences, v. 35, p. 1-43.

Cook, R. A., R. Sutherland, and H. Zhu, 1999, Cretaceous-Cenozoic Geology and Petroleum Systems of the Great South Basin, New Zealand: IGNS Monograph 20, Institute of Geological and Nuclear Sciences, Lower Hutt, New Zealand.

Corfield, R., and J. Cartlidge, 1992, Oceanographic and climatic implications of the Palaeocene carbon isotope maximum: Terra Nova, v. 4, p. 443-455.

Crampton, J. S., 1988, Stratigraphy and structure of the Monkey Face area, Marlborough, New Zealand, with special reference to shallow marine Cretaceous strata: New Zealand journal of geology and geophysics, v. 31.

Crouch, E., 2001, Dinoflagellate cyst biostratigraphy across the Paleocene-Eocene transition of New Zealand. In: Crouch, E., Environmental Change at the Time of the Paleocene-Eocene Biotic Turnover, LPP Contribution Series, 14, pp. 15-69.

Crown Minerals (2008). New Zealand's Petroleum Basins. Retrieved Jamuary 23, 2010, from http://www.crownminerals.govt.nz/cms/pdf-library/petroleum-publications-1/new-zealandspetroleum-basins-report.

Crown Minerals (2009). Canterbury Basin exploration potential. Retrieved January 23, 2010, from http://www.crownminerals.govt.nz/cms/pdf-library/ petroleum-basins1/canterbury_basin_expl_potential.pdf.

Crux, J. A., Eaton, G.L., Sturrock, S.J., Gibbons, M.J., and Herridge, K.J., 1984, Clipper-1 Canterbury Basin, New Zealand. 1. Biostratigraphy report. 2. Maturity \& Source Potential report. PPL38202: Petroleum Report Series PR 1044, Unpublished Petroleum Report, Ministry of Economic Development, New Zealand.

Field, B. D., and G. H. Browne, 1989a, Cretaceous and Cenozoic sedimentary basins and geological evolution of the Canterbury region, South Island, New Zealand: New Zealand Geological Survey, Lower Hutt, New Zealand.

Field, B. D., and G. H. Browne, 1989b, Cretaceous-Cenozoic basin evolution and hydrocarbon potential of Canterbury, New Zealand: 1989 Conference Proceedings, Ministry of Economic Development, New Zealand. 
Field, B. D., and C. I. Uruski, 1997, Cretaceous and Cenozoic Geology and Petroleum Systems of the East Coast Region, New Zealand: IGNS Monograph 19, Institute of Geological and Nuclear Sciences, Lower Hutt, New Zealand.

Fulthorpe, C. S., R. M. Carter, K. G. Miller, and J. Wilson, 1996, Marshall Paraconformity: a mid-Oligocene record of inception of the Antarctic circumpolar current and coeval glacioeustatic lowstand?: Marine and Petroleum Geology, v. 13, p. 61-77.

Gibbons, M. J., and S. Fry, 1986, A Geochemical Study of the Galleon-1 Well, Canterbury Basin, Offshore New Zealand: Petroleum Report Series PR 1146, Unpublished Petroleum Report, Ministry of Economic Development, New Zealand.

Gibbons, M. J., and R. G. Jackson, 1980, A Geochemical Review of the Great South Basin (incorporating previously unreported data for Kawau-1 and Toroa-1): Petroleum Report Series PR 902. Unpublished Petroleum Report, Ministry of Economic Development, New Zealand.

Gibbons, M. J., and R. G. Jackson, 1984, Maturity and source potential of Clipper-1, Canterbury Basin, offshore New Zealand: Petroleum Report Series PR 1044, Unpublished Petroleum Report, Ministry of Economic Development, New Zealand.

GNS, 2009, Well Sheets for the Offshore Canterbury Basin: Unpublished GNS Science Report, IGNS, New Zealand.

Gregg, D. R., 1959, Stratigraphy of the Lower Waipara Gorge, North Canterbury: New Zealand Journal of Geology and Geophysics, 2 (3): 501-27.

Haq, B. U., J. Hardenbol, and P. R. Vail, 1987, Chronology of fluctuating sea levels since the Triassic: Science, v. 235, p. 1156-1167.

Haskell, T. R., 1989a, The Canterbury Basin New Zealand. A Geological and Seismic Evaluation of the Basins Hydrocarbon Potential: Petroleum Report Series PR 1320, Unpublished Petroleum Report, Ministry of Economic Development, New Zealand.

Haskell, T., R, F. Hamsen, J, M, and S. Perry, M, 1989b, A petroleum geology analysis of the Canterbury Basin, New Zealand: 1989 Conference Proceedings, Ministry of Economic Development, New Zealand.

Haskell, T., and I. Wylie, 1997, New Zealand's Canterbury Basin prospects reviewed in a continental Gondwana setting: Oil and Gas Journal, 1997, 95/50 (57-62): Journal of African Earth Sciences, v. 27, p. XVII-XVII.

Haskell, T. R., 2000, Structural and petroleum systems review PEP38254. Canterbury Basin, South Island, New Zealand: Petroleum Report Series PR 2576, Unpublished Petroleum Report, Ministry of Economic Development, New Zealand. 
Hawkes, P. W., and D. G. Mound, 1984, Drilling completion report, Clipper-1. Offshore Canterbury, South Island, New Zealand. PPL38202: Petroleum Report Series PR 1036, Unpublished Petroleum Report, Ministry of Economic Development, New Zealand.

Hayward, B.W., 1986, A guide to paleoenvironmental assessment using New Zealand Cenozoic foraminiferal faunas: New Zealand Geological Survey Report PAL 109, p. 73.

Hearst, J. R., P. H. Nelson, and F. L. Paillet, 1985, Well logging for physical properties: Mc Graw-Hill Book Co., New York, NY.

Herzer, R. H., and R. A. Wood, 1988, The geology and structure of Mernoo Bank and surrounding area, western Chatham Rise: New Zealand Geological Survey Record 29 (1988), p. 22.

Hollis, C. J., 1991, Latest Cretaceous to Late Paleocene Radiolaria from Marlborough (New Zealand) and DSDP site 208: Ph.D. Thesis, University of Auckland.

Hollis, C. J., 1996, Radiolarian faunal change through the Cretaceous-Tertiary transition of eastern Marlborough, New Zealand: Cretaceous-Tertiary Mass Extinctions: Biotic and Environmental Changes, Norton Press, New York, p. 173-204.

Hollis, C. J., G. R. Dickens, B. D. Field, and C. P. Strong, 2000, Age and origin of the Waipawa (black shale) Formation: Geological Society of New Zealand Miscellaneous Publication 108A, 77.

Hollis, C. J., G. R. Dickens, B. D. Field, C. M. Jones, and C. Percy Strong, 2005, The Paleocene-Eocene transition at Mead Stream, New Zealand: a southern Pacific record of early Cenozoic global change: Paleogeography, Palaeoclimatology, Palaeoecology, v. 215, p. 313343.

Hollis, C. J., B. D. Field, E. M. Crouch, and R. Sykes, 2006, How good a source rock is the Waipawa (Black Shale) Formation beyond the East Coast Basin? An outcrop-based case study from Northland. In: 2006 New Zealand Petroleum Conference Proceedings, Crown Minerals, Ministry of Economic Development, New Zealand.

Hornibrook, N.de B. 1968, Handbook of New Zealand microfossils: D.S.I.R. Information Series 62: $136 \mathrm{pp}$.

Hornibrook, N. d. B., J. I. Raine, and G. T. Wilson, 1975, Report on the biostratigraphy of Resolution-1, offshore well: Petroleum Report Series PR 648, Unpublished Petroleum Report, Ministry of Economic Development, New Zealand.

Isaac, M. J., R. H. Herzer, F. J. Brook, and B. W. Hayward, 1994, Cretaceous and Cenozoic sedimentary basins of Northland, New Zealand: Institute of Geological and Nuclear Sciences Monograph, v. 8, p. 203. 
Jackson, R. G., and P.M. Harrington, 1982, Source potential values from pyrolysis techniques of Tertiary and Upper Cretaceous sediments from wells Endeavour-1 and Resolution-1, Canterbury Basin: Petroleum Report Series PR 907, Unpublished Petroleum Report, Ministry of Economic Development, New Zealand.

Jones, R. W., G. L. Eaton, E. M. Finch, J. A. Pearce, and J. E. Williams, 1986, The Biostratigraphy of BPST(C) well Galleon-1, Contract area PPL38203, Canterbury Basin, New Zealand. In: Well Completion Report Galleon-1. PPL 38203: Petroleum Report Series PR 1146, Unpublished Petroleum Report, Ministry of Economic Development. New Zealand.

Kaiho, K., 1991, Global changes of Paleogene aerobic/anaerobic benthic foraminifera and deep-sea circulation: Paleogeography, Palaeoclimatology, Palaeoecology, v. 83, p. 65-85.

Kaiho, K., H. E. G. Morgans, and H. Okada, 1993, Faunal turnover of intermediate--water benthic foraminifera during the Paleogene in New Zealand: Marine Micro-paleontology, v. 23, p. 51-86.

Kaiho, K., 1994, Benthic foraminiferal dissolved-oxygen index and dissolved-oxygen levels in the modern ocean: Geology, v. 22, p. 719.

Kaiho, K., T. Arinobu, R. Ishiwatari, H. Morgans, H. Okada, N. Takeda, K. Tazaki, G. Zhou, Y. Kajiwara, and R. Matsumoto, 1996, Latest Paleocene benthic foraminiferal extinction and environmental changes at Tawanui, New Zealand: Paleoceanography, v. 11, p. 447-465.

Kamp, P. J. J., 1986, Late Cretaceous-Cenozoic tectonic development of the southwest pacific region: Tectonophysics, v. 121, p. 225-251.

Kamp, P. J. J., 1991, Investigation of the thermal \& tectonic history of Galleon-1 \& Endeavour-1 hydrocarbon wells, Canterbury Basin, New Zealand PPL38203 PPL38252:

Petroleum Report Series PR 1796, Unpublished Petroleum Report, Ministry of Economic Development, New Zealand.

Kennett, J., and L. Stott, 1991, Abrupt deep-sea warming, palaeoceanographic changes and benthic extinctions at the end of the Palaeocene: Nature, v. 353, p. 225-229.

Killops, S. D., A. D. Woolhouse, R. J. Weston, and R. A. Cook, 1994, A geochemical appraisal of oil generation in the Taranaki Basin, New Zealand: AAPG Bulletin-American Association of Petroleum Geologists, v. 78, p. 1560-1585.

Killops, S. D., H. E. G. Morgans, and D. A. Leckie, 1996, The Waipawa Black Shale-a ubiquitous super source rock? In: 1996 New Zealand Petroleum Conference proceedings. p. 12-21, Ministry of Commerce, Wellington, New Zealand, p. 12-21.

Killops, S. D., R. A. Cook, R. Sykes, and J. P. Boudou, 1997, Petroleum potential and oilsource correlation in the Great South and Canterbury Basins: New Zealand Journal of Geology and Geophysics, v. 40, p. 405-424. 
Killops, S. D., C. J. Hollis, H. E. G. Morgans, R. Sutherland, B. D. Field, and D. A. Leckie, 2000, Paleoceanographic significance of Late Paleocene dysaerobia at the shelf/slope break around New Zealand: Paleogeography, Palaeoclimatology, Palaeoecology, v. 156, p. 51-70.

King, P. R., and G. P. Thrasher, 1995, Cretaceous-Cenozoic geology and petroleum systems of the Taranaki Basin, New Zealand: Institute of Geological \& Nuclear Sciences monograph 13, Institute of Geological \& Nuclear Sciences.

Leckie, D. A., H. E. G. Morgans, G. J. Wilson, and C. I. Uruski, 1992, Stratigraphic framework and source-rock potential of Maastrichtian to Paleocene marine shale, East Coast, North Island, New Zealand: Hydrocarbon Prospects: Institute of Geological \& Nuclear Sciences science report 92, v. 5.

Leckie, D. A., H. Morgans, G. J. Wilson, and A. R. Edwards, 1995, Mid-Paleocene dropstones in the Whangai Formation, New Zealand-evidence of mid-Paleocene cold climate?: Sedimentary Geology, v. 97, p. 119-129.

Lewis, D. W., 1992, Anatomy of an unconformity on mid-Oligocene Amuri Limestone, Canterbury, New Zealand: New Zealand Journal of Geology \& Geophysics, v. 35, p. 463-475.

Mann, U., and P. J. Müller, 1988, Source rock evaluation by well log analysis (Lower Toarcian, Hils syncline): Organic Geochemistry, v. 13, p. 109-119.

Meadows, D. J., 2009, Stable isotope geochemistry of Paleocene to Early Eocene strata around southern New Zealand: Unpublished Masters Thesis, Victoria University of Wellington, New Zealand.

Milne, A. D., 1975, Resolution-1 Well Completion Report: Petroleum Series PR 648, Unpublished Petroleum Report, Ministry of Economic Development, New Zealand.

Mitchum, R. M., 1977, Seismic stratigraphy and global changes of sea level, Part 1: Glossary of terms used in seismic stratigraphy: Seismic stratigraphy: Applications to hydrocarbon exploration: American Association of Petroleum Geologists Memoir, v. 26, p. 205-212.

Mitchum, R. M., P. R. Vail, and J. B. Sangree, 1977, Seismic stratigraphy and global changes of sea level, part 6: stratigraphic interpretation of seismic reflection patterns in depositional sequences: Seismic stratigraphy-Applications to hydrocarbon exploration: AAPG Memoir, v. 26, p. 117-133.

Mogg W.G., Aurisch K., O'Leary R., and Pass G.P. Offshore Canterbury Basin-Beyond the shelf edge. 2008 Conference Proceedings, Ministry of Economic Development, New Zealand.

Moore, P. R., L. R. Snowdon, and K. G. Osadetz, 1987, Maturation and petroleum source rock potential of the Whangai and Waipawa formations (Late Cretaceous-Paleocene), eastern North Island: New Zealand Geological Survey record, v. 20, p. 17-23. 
Moore, P. R., 1988, Stratigraphy, composition, and environment of deposition of the Whangai Formation and associated Late Cretaceous-Paleocene rocks, eastern North Island, New Zealand: New Zealand Geological Survey Bull. 100. IGNS, Lower Hutt.

Moore, P. R., 1989, Stratigraphy of the Waipawa Black Shale (Paleocene), eastern North Island, New Zealand: New Zealand Geological Survey Record, v. 38, p. 19.

Mound, D. G., and Pratt, D.N., 1984, Interpretation and prospectivity of PPL 38202, Canterbury Basin, New Zealand. Petroleum Report Series PR 1021, Unpublished Petroleum Report, Ministry of Economic Development, New Zealand.

North, F. K., 1985, Petroleum Geology: Alwin \& Unwin.

Perry, S., 1991, PPL38251 Offshore Canterbury seismic interpretation report. Petroleum Report Series PR 1783, Unpublished Petroleum Report, Ministry of Economic Development, New Zealand.

Pocknall, D., I. Raine, C. Strong, and G. Wilson, 1991, Biostratigraphic revision of Mata \& Dannevirke series (Late Cretaceous to early Eocene) in Endeavour-1 \& Galleon-1 exploration wells, Canterbury New Zealand PPL38252: Petroleum Report Series PR 1806, Unpublished Petroleum Report, Ministry of Economic Development, New Zealand.

Raine, J. I., C. P. Strong, and G. J. Wilson, 1993, Biostratigraphic revision of petroleum exploration wells, Great South Basin, New Zealand: IGNS Science Report 93/32, Institute of Geological and Nuclear Sciences, Lower Hutt, New Zealand.

Raine, J. I., C. P. Strong, G. J. Wilson, and D. T. Pocknall, 1994, Biostratigraphic revision of the Late Cretaceous to Early Eocene in selected offshore exploration wells, South Canterbury Bight, New Zealand: Institute of Geological and Nuclear Sciences Science Report, v. 94, p. 30.

Rogers, K. M., J. D. Collen, J. H. Johnston, and N. E. Elgar, 1999, A geochemical appraisal of oil seeps from the East Coast Basin, New Zealand: Organic Geochemistry, v. 30, p. 593-605.

Rogers, K. M., H. E. G. Morgans, and G. S. Wilson, 2001, Identification of a Waipawa Formation equivalent in the upper Te Uri Member of the Whangai Formation-implications for depositional history and age: New Zealand Journal of Geology and Geophysics, v. 44, p. 347354.

Roksandic, M. M., 1978, Seismic Facies Analysis Concepts: Geophysical Prospecting, v. 26, p. 383-398.

Schiøler, P., K. Rogers, R. Sykes, C. J. Hollis, B. Ilg, D. Meadows, L. Roncaglia, and C. Uruski, 2009, Palynofacies, organic geochemistry and depositional environment of the Tartan Formation (Late Paleocene), a potential source rock in the Great South Basin, New Zealand: Marine and Petroleum Geology, v. 27, p. 351-369. 
Schioler, P., and L. Roncaglia, 2008, Age and depositional environment of the Tartan Formation, a potential source rock in the Great South Basin. In: 2008 New Zealand Petroleum Conference Proceedings, Crown Minerals, Ministry of Economic Development, New Zealand.

Schroeder, A. G., 1971, The Micro-paleontology of the Endeavour-1 well. In Endeavour-1 Well Completion Report: Petroleum Report Series PR 303, Unpublished Petroleum Report, Ministry of Economic Development, New Zealand.

Serra, O., 1986, Fundamentals of Well-log Interpretation: The interpretation of logging data: Elsevier Publishing Company.

Sheriff, R. E., 1976, Inferring stratigraphy from seismic data: AAPG Bull, v. 60, p. 528-542.

Simpson, J., 1993, Review of the geochemistry of lower Katiki and Clipper Formations in Endeavour-1 and biostratigraphy of the Cretaceous to Eocene section in Clipper-1 implications for the petroleum geology of the Canterbury Basin: Petroleum Report Series PR 1997, Unpublished Petroleum Report, Ministry of Economic Development, New Zealand.

Snedden, J. W., and J. F. R. Sarg, 2008, Seismic Stratigraphy-A Primer on Methodology, Search and Discovery Article \#40270. Retrieved March 10, 2009, from http://www.searchanddiscovery.net/documents/2008/08004snedden/images/snedden.pdf.

Strong, C. P., C. J. Hollis, and G. J. Wilson, 1995, Foraminiferal, radiolarian, and dinoflagellate biostratigraphy of Late Cretaceous to Middle Eocene pelagic sediments (Muzzle Group), Mead Stream, Marlborough, New Zealand: New Zealand journal of geology and geophysics, v. 38, p. 171-171.

Strong, C. P., and C. J. Hollis, 2009, Conference Field Trip Guides. Climatic and Biotic Events of the Paleogene: GNS Science. Wellington, New Zealand. .

Sutherland, R., and G. Browne, 2003, Canterbury Basin offers potential on South Island, New Zealand: Oil and Gas Journal, v. 101, p. 45-50.

Sykes, R., and Funnell, R.H., 2002, Petroleum source rock potential and generation history in the offshore Canterbury Basin: Petroleum Report Series PR 2707, Unpublished Petroleum Report, Ministry of Economic Development, New Zealand.

Tag Oil Ltd. (2007). Geological Proposal Salmon-1: Petroleum report Series PR 3628. Unpublished Petroleum Report, Ministry of Economic Development. New Zealand.

Vail, P. R., R. M. Mitchum, and S. Thompson, 1977, Seismic stratigraphy and global changes of sea level, part 3: relative changes of sea level from coastal onlap, in Seismic StratigraphyApplications to Hydrocarbon Exploration: AAPG Memoir 26, p. 49-212. 
Vail, P. R., 1987, Seismic stratigraphy interpretation using sequence stratigraphy; Part 1, Seismic stratigraphy interpretation procedure, In: A.W. Bally, ed. Atlas of Seismic Stratigraphy: AAPG Studies in Geology no. 27; v. 1, p. 1-10.

Vajda, V., and J. Raine, 2003, Pollen and spores in marine Cretaceous/Tertiary boundary sediments at mid-Waipara River, North Canterbury, New Zealand: New Zealand journal of geology and geophysics, v. 46, p. 255-274.

Warren, G., and I. G. Speden, 1978, The Piripauan and Haumurian stratotypes (Mata Series, Upper Cretaceous) and correlative sequences in the Haumuri Bluff district, South Marlborough (S56), Dept. of Scientific and Industrial Research, Wellington, N.Z.

Wilding, A., and L. A. Sweetman, 1971, Endeavour-1 Well Completion Report. Petroleum Report Series PR 303: Unpublished Petroleum Report, Ministry of Economic Development, New Zealand.

Wilson, G.J., 1984. New Zealand Late Jurassic to Eocene dinoflagellate biostratigraphy—a summary. Newsletters on Stratigraphy 13, 104-117.

Wilson, I. R., 1985, Well Completion Report of Galleon-1 PPL38203: Petroleum Report Series PR 1146, Unpublished Petroleum Report, Ministry of Economic Development, New Zealand.

Wilson, G., 1988, Paleocene and Eocene dinoflagellate cysts from Waipawa, Hawkes Bay, New Zealand, New Zealand Geological Survey.

Wood, R. A., P. B. Andrews, and R. H. Herzer, 1989, Cretaceous and Cenozoic geology of the Chatham Rise region, South Island, New Zealand: NZ Geological Survey Basin Studies 3.

Zachos, J. C., K. C. Lohmann, J. C. G. Walker, and S.W. Wise, 1993. Abrupt climate change and transient climates during the Paleogene: a marine perspective: Journal of Geology 101, $191-213$.

Zachos, J., M. Wara, S. Bohaty, M. Delaney, M. Petrizzo, A. Brill, T. Bralower, and I. Premoli-Silva, 2003, A transient rise in tropical sea surface temperature during the PaleoceneEocene thermal maximum: Science, v. 302, p. 1551. 


\section{Appendix A. New Zealand Paleogene Timescale}

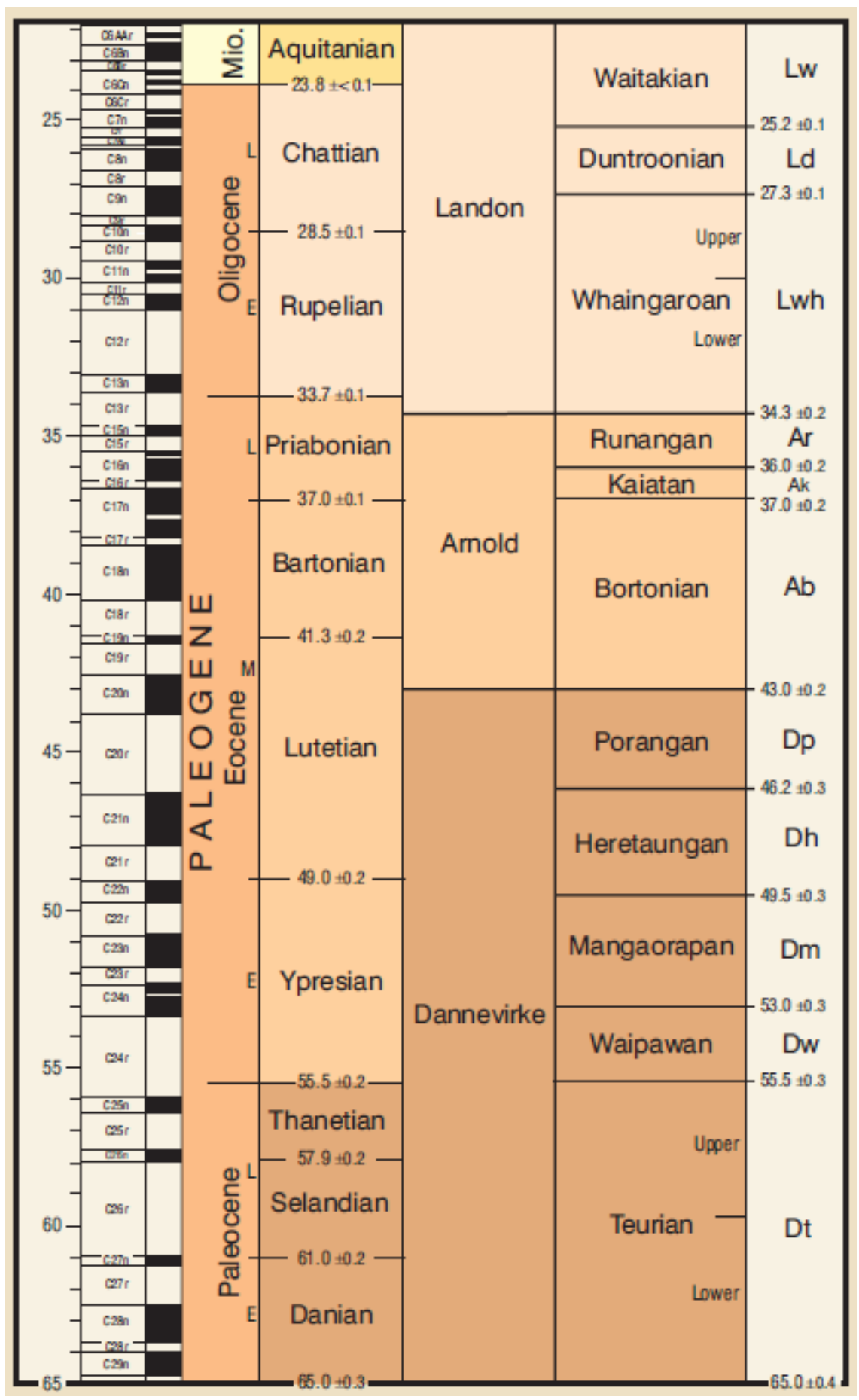

Modified from Cooper (2004) 


\section{Appendix B. Biostratigraphy of the Paleocene and Eocene interval in the offshore Canterbury Basin wells}

\section{Galleon-1}

The original biostratigraphic assessment of the Galleon-1 well was undertaken by Jones et al., (1986) and the following is a summary of the biostratigraphic information for the Paleocene and Eocene interval in the well. In the original biostratigraphic interpretation of the well, the interval from 1880m-1890m at Galleon-1 was assigned to the Globigerapsis index Biozone due to the presence of the foraminifera Globigerapsis index \& Globigerina ex gr. linaperta, and these species were used to indicate an age no younger than Runangan (Runangan) (Jones et al., 1986). The benthic forms Cibicides parki (not younger than Runangan) \& Uvigerina bortotara (no younger than basal Oligocene), also corroborated the planktonic assemblages to indicate a Late Eocene (Runangan) age. This interval differed from the above interval by its clastic preservation, presence of Globigerapsis index and Globigerina ex gr. linaperta. The interval from 1900m-1901m was assigned to the Sphaeroidina variabilis Biozone as it contained Sphaeroidina variabilis which in New Zealand indicates an age range from Bortonian (Ab) to Kaiatan (Ak). Although this interval had similar species as the overlying Globigerapsis index interval, the notable difference was the presence of Sphaeroidina variabilis. At $1914.5 \mathrm{~m}$ the presence of Globigerina boweri together with Globigerapsis index, Globigerina frontosa and Globigerinita turgida was used to indicate an age of Porangan (Dp). This zone differs from the previous biozone by containing Globigerina boweri, Globigerina frontosa and Globigerinita turgida. The interval from $1950 \mathrm{~m}-2595 \mathrm{~m}$ was assigned to the Agglutinate Interval Biozone. Here, Globigerina frontosa and Elphidium Hamdenense was used to indicate an age of Heretaungan. Below $2381 \mathrm{~m}$ the age was unclear, being possibly Mangaorapan, Waipawan or Late Teurian. Bolivinopsis cubensis at 2396.3m indicated Waipawan. This interval differed from the previous interval by the absence of Globigerina boweri and the dominance of agglutinated foraminifera. The interval from $2603 \mathrm{~m}-2654 \mathrm{~m}$ was assigned to the Bolivinopsis spectabilis Biozone. Here, Bolivinopsis spectabilis in New Zealand indicates an age no younger than Teurian. Globigerina triloculinoides also indicates Early Eocene-Paleocene. Accordingly this interval was taken to be Teurian to Waipawan or even till Mangaorapan and it differed from the previous interval by containing Bolivinopsis 
spectabilis, Buliminella creta and Conotochammina whangaia. The interval from $2690 \mathrm{~m}-$ $2672 \mathrm{~m}$ was assigned to the Globigerina pauciloculata Biozone. The presence of Globigerina pauciloculata here was used to indicate an age within Early Teurian. This interval differed from the previous intervals by containing Globigerina pauciloculata. The next interval from 2690m-2735m was assigned to the Dorothia elongata Biozone. The top of this interval marks the Cretaceous-Tertiary boundary and the presence of Dorothia elongata was used to indicate a Haumurian age and was also supported by the presence of a questionable specimen of Gaudryina healyi. This interval differs from the above interval by the absence of Tertiary planktonic foraminifera and the presence of Dorothia elongata. No palynological analysis was undertaken for the Galleon-1 well in the original biostratigraphic assessment.

A review of the biostratigraphy in the Galleon-1 well was undertaken by Pocknall et al., (1991) for the interval between $2400 \mathrm{~m}-3031 \mathrm{~m}$, spanning the Cretaceous to Early Eocene and this is a summary of their biostratigraphic review. Micro-paleontological analysis of a sample at 2400m indicated a Waipawan-Early Mangaorapan age based on the occurrence of Globigerina triloculinoides and the absence of any diagnostic Teurian taxa. From 2450m, cuttings contained the highest occurrences of Budashevaella multicamerata and Bolivinopsis cf. B. spectabilis and lacked any Cretaceous restricted taxa, and this was used to indicate a Teurian age. The Cretaceous-Tertiary boundary was placed at the highest occurrence of the Haumurian index species, Gaudryina healyi, at $2642 \mathrm{~m}$. Palynological analysis of samples at 2396.3m contained Proteacidites asperatus, who's FAD (First Appearance Datum) is Waipawan. Spores and pollen were more common in the $2400 \mathrm{~m}$ sample. Spores, pollen and dinoflagellates identified in this sample at 2400m indicated an age of Early Waipawan. Cuttings from 2440m yielded assemblages characteristic of the Palaeocystodinium golzowense zone which is considered to lie just below the Teurian-Waipawan boundary. The upper limit of Tricolporites lilliei, Quadraplanus brossus and Beaupreadites n.sp in cuttings from 2642m-2645m indicated that the Cretaceous-Tertiary boundary lies there, and accordingly this marked the top of the Haumurian Stage. 
A subsequent biostratigraphic review of the Paleocene to Eocene interval in the Galleon-1 well by Raine et al., (1994) came to similar conclusions for the Paleocene and Eocene interval as the review by Pocknall et al., (1991) summarised above.

\section{Endeavour-1}

The original biostratigraphic assessment of the Galleon-1 well was undertaken by Schroeder, (1971), and the following is a summary of the biostratigraphic information for the Paleocene and Eocene interval in the well. In the Endeavour-1 well, the first Eocene sediments encountered were of Kaiatan age, with the Runangan Stage seen to be absent. Sediments from $1259 \mathrm{~m}-1298 \mathrm{~m}$ were assigned a Kaiatan age based on the presence of foraminifera Globigerapsis index \& Globigerina linaperta in a sample at $1262 \mathrm{~m}$ which indicated an Eocene age. The presence of Pseudogloboquadrina primitiva (Waipawan-basal Kaiatan) at 1280m indicated that the age at that level was not younger than Kaiatan. The presence of Sphaeroidina variabilis (Bortonian-Kaiatan) at $1262 \mathrm{~m}$ and $1265 \mathrm{~m}$ also indicated that Kaiatan was reached. The co-occurrence of Gaudryina proreussi \& Bulimina bortonica at $1298.5 \mathrm{~m}$ was used to mark the top of the Bortonian. At 1386.8m Uvigerina wanzea (PoranganBortonian) was recorded. The interval from 1298m-1454m was assigned an age of Bortonian. Samples from 1454m-1494m contained no planktonic forams and the benthic species were mainly arenaceous. The Porangan marker species Elphidium saginatum was not present and so Porangan was not conclusively seen to be present. However this interval was tentatively assigned an age of Porangan. The typical Heretaungan marker, Elphidium hampdenensis was seen at $1493.5 \mathrm{~m}$ and planktonics appeared for the first time (Globigerina triloculonoides \& Globorotalia aequa rex). The interval from 1494m-1576m was assigned a Heretaungan age. The top of the Mangaorapan Stage was marked by the absence of Elphidium hampdenensis at $1575.8 \mathrm{~m}$ and deeper. The interval from $1615 \mathrm{~m}-1975 \mathrm{~m}$ was assigned an age of Waipawan as indicated by the presence of Bigenerina burri at $1615 \mathrm{~m}$. The samples in this interval contained the foraminifera Bigenerina burri, Allomorphina aff. Whangaia and Ceratabulimina waipawaensi $M S$ which were found a few times onshore in samples not younger than Waipawan. There was a lack of prominent forms to separate the Waipawan from the Teurian and hence they were taken together. The top of the Cretaceous was marked at $1975 \mathrm{~m}$. The 
presence of numerous specimens of Dorothia aff. elongata at 2033m, 1975.1m and 1984.24m indicated that the Cretaceous succession had been penetrated.

Palynological analyses were carried out over the Cretaceous to Eocene succession in the original biostratigraphic review of the Endeavour-1 well. At 1984m the presence of Baltisphaeridium, a microplankton genus was thought to indicate proximity to the CretaceousTertiary boundary. The sample from $1737 \mathrm{~m}$ was found to contain several species, all of which indicated an age no older than Teurian. These species included Nothofagidites waipawaensis, Tricolpites secarius and Engelhardtioidites minisculus. From palynological analysis, the top of the Teurian was inferred to be between $1734 \mathrm{~m}$ and $1719 \mathrm{~m}$ as there was a disappearance of the Teurian species Clavifera triplex and Nothofagidites waipawaensis here. In addition, the first appearance of Proteacidites hakeoides and P. annulari, both of which first occur in the Waipawan also indicated that the boundary between the Teurian and the Waipawan was within this interval.

The biostratigraphy of the interval from $1554.5 \mathrm{~m}-2740 \mathrm{~m}$ (Cretaceous-Eocene) was reviewed by Pocknall et al., (1991). The following is a brief summary of their biostratigraphic revision of the Paleocene to Eocene interval.

The interval from 1676m-1719m was assigned an age of Waipawan to Heretaungan on the basis of palynological analysis, with the presence of several species of Proteacidites, Spinizonocolpites prominatus, and the abundance of Haloragicidites harrisii helping to constrain the age. Dinoflagellates were seen to be common in the interval and included several species of Impagidinium, Wilsonidiumm cf. W. ornatum, Kisselovia coleothrypta and Deflandrea truncata. The boundary of the Waipawan to the Mangaorapan was picked from micro-paleontological analysis on the basis of the highest occurrence of Bigernerina burri at $1615.44 \mathrm{~m}$, as this species is restricted to the Waipawan Stage. The co-occurrence of Globigerina boweri (Mangaorapan-Heretaungan) here also indicated that this sample was right at the stage boundary. 
The interval from 1719.1m-1968.9m was assigned a Teurian age on the basis of palynological and micro-paleontological analysis of samples between $1734.31 \mathrm{~m}-1944.62 \mathrm{~m}$. The upper part of this interval from $1734 \mathrm{~m}-1767.8 \mathrm{~m}$ was seen to be indicative of the Late Teurian Stage, as palynological analysis showed the samples contained low abundances of both Phyllocladidites mawsonii and Haloragacidites harrisii, several species of bisaccate conifer pollen, common Triorites minor and relatively abundant Nothofagidites waipawaensis. A Middle Teurian age was inferred for the section from 1798.3m-1944.6m on the basis of the absence of Proteacidites species and Haloragicidites harrisii which indicates an age no younger than middle Teurian. Micro-paleontological analysis of the samples within this interval $(1719.1 \mathrm{~m}-$ $1968.9 \mathrm{~m}$ ) indicated that the Teurian-Waipawan boundary was above $1636.7 \mathrm{~m}$ (on tentative identification of Contotrochammina whangaia) and more confidently at above $1697.7 \mathrm{~m}$ as a sidewall core sample at $1697.7 \mathrm{~m}$ contained several species with a Haumurian to Teurian age range including Cyclammina elegans, Bolivinopsis spectabilis and Budashevaella multicamerata.

Palynological analysis indicated that the Cretaceous-Tertiary boundary was at or immediately above 1975.1m. Evidence for this was observed in cuttings samples from 1972m-1975m, which contained abundant Trithrodinium evitii (which is an index species for the earliest Teurian Dinoflagellate zone) and Palaeoperidinium pyrophorum, which is know to occur below the Paleocene only very rarely. The majority of species observed palynologically from 1972m-1975m were recorded from the Cretaceous-Tertiary boundary interval at Waipara, Canterbury and further showed that this level was very near the Cretaceous-Tertiary boundary. At $1975 \mathrm{~m}$ the key Dinoflagellate species Manumiella drugii and M. seelandica indicated Latest Haumurian age, along with other typical species of the Cretaceous-Tertiary boundary zone. Together, with the absence of Trithyridinium evittii and its presence further down hole, it was concluded that the Cretaceous-Tertiary boundary was at or immediately above $1975 \mathrm{~m}$.

Micro-paleontological work carried out by Pocknall et al., (1991) over the CretaceousTertiary boundary interval also placed the boundary within $1975 \mathrm{~m}-1978 \mathrm{~m}$. There were sparse agglutinated fauna in cuttings from 1972m-1975m, which however, contained a tentative sample of Bolivinopsis compta (Teurian-Bortonian), and no Cretaceous restricted species 
were recorded. The presence of the Haumurian index species Gaudryina healyi was recorded in cuttings from 1975m-1978m and therefore, the Cretaceous-Tertiary boundary was placed within the $1975 \mathrm{~m}-1978 \mathrm{~m}$ (drilling depth) interval.

The review by Raine et al., (1994) came to similar conclusions as the findings by Pocknall et al., (1991) summarised above.

\section{Clipper-1}

The following is a brief summary of the biostratigraphy presented in the original well completion report for the Clipper-1 well by Crux (1984). The Clipper-1 well was inferred to have penetrated Runangan age sediments from $2350 \mathrm{~m}-2385 \mathrm{~m}$. A sample at $2340 \mathrm{~m}$ recorded the first occurrence of Globigerapsis index which shows a Runangan to Late Porangan age. Subbotina linaperta also shows Runangan age. At $2355 \mathrm{~m}$ Globigerapsis index is present with Uvigerina bortotara (Runangan-Bortonian) and at $2365 \mathrm{~m}$ the benthic Cibicides parki (Runangan-Bortonian) was recorded. There was no direct evidence for the penetration of Kaiatan strata, although it could have either been present within the interval just described, or it was absent or highly condensed. Bortonian age sediments were inferred to have been penetrated from $2385 \mathrm{~m}-2410 \mathrm{~m}$ as a sample at $2390 \mathrm{~m}$ contained Zeauvigerina parvi \& a single specimen of benthic foram Hopkinsina wanzea (Bortonian-Porangan). At $2410 \mathrm{~m}$ the presence of Globigerapsis index \& Globigerina frontosa boweri together indicated Porangan age. Globigerina boweri was recorded which is indicative of the Porangan Stage. The benthic foram Bulimina subortonica was also observed, which was previously recorded in Dannevirke strata. Elphidium saginatum, a benthonic index for Porangan was recorded at $2455 \mathrm{~m}$. The nannofossil Chiasmolithus bidens at 2460m together with Eocene restricted Neococolithus dubius indicated the penetration of Early Eocene sediments. This together with the presence of the Porangan cyst Wilsonidium echinosuturum at $2475 \mathrm{~m}$ indicated that the Heretaungan was unrepresented or condensed. Within this interval, confirmation of a Mangaorapan age to $2540 \mathrm{~m}$ was provided by the occurrence of Vaginulinopsis marshalli. From 2560m, no age diagnostic fauna were recorded and the interval from $2560 \mathrm{~m}-2790 \mathrm{~m}$ was tentatively taken to be Mangaorapan to Waipawan. At 2694m the Dinoflagellate cyst genus Apectodinium was 
recorded. In New Zealand, this is associated with the Waipawan-Teurian boundary but with a range bias towards the Teurian (Wilson, 1984). From 2790m-3175m, paleontological samples indicated Teurian. At 2790 abundant, low diversity, agglutinated assemblages comprising Haplophragmoides sp., Cyclamina grangeri \& Karreriella sp were recorded, which is also observed at Waipawa from the Teurian (Hornibrook, 1968). At $2895 \mathrm{~m}$ benthonic taxa Gaudryina whangia confirmed Teurian and at 2940m Spiroplectammina spectabilis (TeurianHaumurian) with Loxostomoides aff. Limonense (Teurian) was recorded. At 2800m onwards the dinoflagellate cyst genus Palaeocystodinium was present which in New Zealand is not younger than Teurian (Wilson, 1984). At 3100m palaeoperidinium pyrophorum was recorded which is also not younger than Teurian (Wilson, 1984). At 3150m Trithyrodinium evitii suggested Early Paleocene age when compared with Australian data (Wilson, 1984). Isabelidinium drugii is associated with the Cretaceous-Tertiary boundary in New Zealand and was recorded at $3175 \mathrm{~m}$.

A review of the dinoflagellate biostratigraphy of the Clipper-1 well in the interval from 2775m-663m (Cretaceous to Paleocene) was undertaken by Wilson (1986). The sample at $2775 \mathrm{~m}-2780 \mathrm{~m}$ was seen to contain a reasonably rich palynomorph assemblage dominated by spores and pollen. Dinoflagellate cysts included palaeocystodinium glowense, Ceratiopsis striata, Senegalinium dilwynense, Deflandrea medcalfii, Spinidinium, sp. and indicated that the age was clearly Early to Mid Teurian (Wilson 1986). The sample at 2785m-2790m, and the one at $2800 \mathrm{~m}$ to $2805 \mathrm{~m}$ also contained similar dinoflagellate assemblages as the one above and also gave an age from Early to Mid Teurian. Samples below these were all Cretaceous.

Raine et al., (1994) analysed the Upper Cretaceous to Early Eocene section (4684.5m-2600m) in the Clipper-1 well. The interval from $2580 \mathrm{~m}-3167 \mathrm{~m}$ was assigned an age of Teurian to Waipawan/ Mangaorapan. The cuttings samples at 2775m, 2785m and 2800m, contained well-preserved and diverse dinoflagellate assemblages with Palaeocystodinium golzowense, which indicated Middle to Upper Teurian age. Miospores were seen to be common in these three samples. The one at $2775 \mathrm{~m}$ was seen to contain the miospore Tricolporites secarius which indicates an age of Paleocene to Early Eocene. Foraminiferal studies of the interval from $2640 \mathrm{~m}-3165 \mathrm{~m}$ recorded sparse, low diversity, entirely agglutinated assemblages 
containing few biostratigraphically significant species. The first definite Teurian assemblage was recorded at $2900 \mathrm{~m}$ indicated by the highest occurrence of Gaudryina whangaia which was present together with Budashevaella multicamerata (Haumurian-Teurian) and Bolivinopsis compta (Teurian-Bortonian). The Cretaceous-Tertiary boundary was placed at between $3180 \mathrm{~m}-3185 \mathrm{~m}$. Cuttings from $3160 \mathrm{~m}-3180 \mathrm{~m}$ were seen to be poorly fossiliferous and the sample in the $3175 \mathrm{~m}-3180 \mathrm{~m}$ interval contained the first occurrence of Manumiella druggii, which is the index fossil for the Latest Cretaceous dinoflagellate zone, which also ranges up into the basal Teurian. Samples in the $3180 \mathrm{~m}$ interval and below contained the first occurrence of the Haumurian index, Gaudryina healyi together with Spiroplectammina piripaua (Haumurian-Teurian), and the top of the Cretaceous-Tertiary boundary was placed at the top of this interval at $3180 \mathrm{~m}$.

\section{Resolution-1}

The following is a summary of the Paleocene and Eocene strata in the Resolution-1 well as described by Hornibrook et al., (1975) in Milne (1975). Eocene sediments were inferred to have been penetrated from $1330 \mathrm{~m}$. Sidewall samples from $1330 \mathrm{~m}-1380 \mathrm{~m}$ were assigned a Late Eocene age. A sample at 1332m contained foraminifera indicative of Runangan age, including Bathysiphon species, Cibicides parki, Globigerapsis index and Globigerina angiporoides. However, the Runangan index species Bolivina pontis was not found in the sample at $1335 \mathrm{~m}$ and was inferred to be either Runangan or Kaiatan age. The sample at $1338 \mathrm{~m}$ was inferred to be of Kaiatan age as it contained Sphaeroidina variabilis and Gaudryina reussi, whose age's range in the Kaiatan, and as the typically Kaiatan species, Bolivina $c f$. moodyensis was found in the next sample at $1348 \mathrm{~m}$. The interval from $1338 \mathrm{~m}-$ $1380 \mathrm{~m}$ was assigned a Kaiatan age. At $1380 \mathrm{~m}$ a typical upper Bortonian fauna was recorded including the Bortonian index species Gaudryina proreussi. The Lower Bortonian was represented by Euvigerina wanzea from 1396m-1415m. The Porangan Stage was not identified. The presence of Elphidium hampdenense in samples from 1410m indicated definitely that Heretaungan sediments were penetrated. Elphidium hampdenense was also present in samples from $1428 \mathrm{~m}$ and $1443 \mathrm{~m}$. The sidewall sample at $1474.5 \mathrm{~m}$ contained a shallow water assemblage of agglutinated foraminifera. The association of Bolivinopsis 
compta and Bolivinopsis spectabilis was used to indicate a Teurian age. The sediments from $1490 \mathrm{~m}-1675 \mathrm{~m}$ were white quartzose sands and foraminifera were not observed to be present within. At 1695m the Haumurian index species Gaudryina healyi was recorded and marked conclusively the penetration of Cretaceous strata. 


\section{Appendix C. Related petroleum, seismic and biostratigraphy reports}

Austral Pacific Energy Ltd. (2006). Seismic Survey Canterbury Basin. Petroleum Report Series PR 3298. Unpublished Petroleum Report, Ministry of Economic Development, New Zealand.

Bounty Oil Company (1970). Wanganui and South Canterbury Reflection Seismic Survey, Final Report. Petroleum Report Series PR 275. Unpublished Petroleum Report, Ministry of Economic Development, New Zealand.

BP Shell Todd (1974). Operational report, marine seismic survey, Canterbury Bight. Petroleum Report Series PR 626. Unpublished Petroleum Report, Ministry of Economic Development, New Zealand.

BP Shell Todd (1974). Reprocessed seismic data for the Canterbury Basin. Petroleum Report Series PR 769. Unpublished Petroleum Report, Ministry of Economic Development, New Zealand.

Brown, L. N. (1975). Tenement Review, PPL1029 \& PPL1043, Canterbury. Petroleum Report Series PR 637. Unpublished Petroleum Report, Ministry of Economic Development, New Zealand.

Core Laboratories (1991). Geochemical and biostratigraphical results for samples from the Canterbury Basin, South Island New Zealand PPL38252. Petroleum Report Series PR 1804. Unpublished Petroleum Report, Ministry of Economic Development, New Zealand.

Cue Energy Resources (1981). Assessment of PPL 38065 Onshore North Canterbury, South Island, NZ. Petroleum Report Series PR 824. Unpublished Petroleum Report, Ministry of Economic Development, New Zealand.

Davies, T. W., and M.A. Ferrett (1969). Marine seismic survey Canterbury Bight. Petroleum Report Series PR 770. Unpublished Petroleum Report, Ministry of Economic Development, New Zealand.

Davies, T. W., and M.A. Ferrett (1969). Marine Seismic Survey, Canterbury Bight. Petroleum Report Series PR 292. Unpublished Petroleum Report. Ministry of Economic Development. New Zealand.
DeGolyer., Naughton, M., and Warren (1969). Review of Geology and Geophysics Canterbury Plains Concession. Petroleum Report Series PR 845. Unpublished Petroleum Report, Ministry of Economic Development, New Zealand.

Department of Scientific and Industrial Research (1977). Kowhai Structure, North Canterbury.

Petroleum Report Series PR 787. Unpublished Petroleum Report, Ministry of Economic Development, New Zealand.

ECL Australia Pty Ltd (1984). Seismic supervision report-Offshore Canterbury PPL 38202/38203. Petroleum Report Series PR 1020. Unpublished Petroleum Report, Ministry of Economic Development, New Zealand.

Fischer, J. C. (1975). Detailed Marine Seismic Survey Interpretation Report, Offshore Canterbury Bight. Petroleum Report Series PR 640. Unpublished Petroleum Report, Ministry of Economic Development, New Zealand.

Fulthorpe, C. S. (2000). R/V Maurice Ewing Cruise EW00-01. High-Resolution Multichannel Seismic Survey, Offshore Canterbury Basin, New Zealand. Petroleum Report Series PR 3128. Unpublished Petroleum Report, Ministry of Economic Development, New Zealand.

Funnell, R. (2005). Petroleum Modelling in PEP38258, Offshore Canterbury Basin, New Zealand. Petroleum Report Series PR 3504. Unpublished Petroleum Report, Ministry of Economic Development, New Zealand.

Geco-Prakla (2000). IPE00-256 Seismic Survey. Canterbury PEP 38256. Petroleum Report Series PR 2480. Unpublished Petroleum Report, Ministry of Economic Development, New Zealand.

Geco-Prakla (1999). PEP 38256, Canterbury Basin seismic survey. Petroleum Report Series PR 2424. Unpublished Petroleum Report, Ministry of Economic Development, New Zealand.

Geiger, M. E. (1959). An outline of the geology of the Canterbury Plains. Petroleum Report Series PR 436. 
Unpublished Petroleum Report. Ministry of Economic Development, New Zealand.

Green Gate Ltd. (2007). Offshore North Canterbury Exploration Progress. Leads and Prospects. Petroleum Report Series PR 3810. Unpublished Petroleum Report. Ministry of Economic Development, New Zealand.

Haw, D. (1961). A geological reconnaissance of the North Canterbury region, South Island, New Zealand. Petroleum Report Series PR 319. Unpublished Petroleum Report, Ministry of Economic Development, New Zealand.

Hill, P. J., and Dean, P (1976). An assessment of the hydrocarbon Prospects in the offshore Canterbury Basin. PPL38003. Petroleum Report Series PR 680. Unpublished Petroleum Report, Ministry of Economic Development, New Zealand.

Hunt, J. A. (1960). Notes on Canterbury Plains and adjoining areas. Petroleum Report Series PR 711. Unpublished Petroleum Report, Ministry of Economic Development, New Zealand.

Jenkins, D. G., McInnes, B.A. (1962). Faunas from the South Canterbury Region South Island New Zealand PN 21. Petroleum Report Series PR 1715.

Unpublished Petroleum Report, Ministry of Economic Development, New Zealand.

Kirkaldy, P. H. S., M.F.Ridd and E.G.Thomas (1963). Seismic Survey, Canterbury Plains (Interim and Final reports). Petroleum Report Series PR 328.

Unpublished Petroleum Report, Ministry of Economic Development, New Zealand.

Maslen, G. (2004). Seismic Reprocessing Offshore Canterbury. Petroleum Report Series PR 3377. Unpublished Petroleum Report, Ministry of Economic Development, New Zealand.

Maxus Energy Corporation (1991). Report for 1991 reprocessing in PPL38252 Canterbury Bight, Offshore New Zealand. Petroleum Report Series PR 1758. Unpublished Petroleum Report, Ministry of Economic Development, New Zealand.

Maxus Energy Corporation (1991). PPL 38252 Annual report, July 15 1990-July 15 1991, Canterbury Bight New Zealand.. Petroleum Report Series PR 1803. Unpublished Petroleum Report, Ministry of Economic Development, New Zealand.

McQuillan, H. (1982). Geologic assessment of the hydrocarbon prospects in the North Canterbury area PPL38065. Petroleum Report Series PR 858.

Unpublished Petroleum Report, Ministry of Economic Development, New Zealand.
NZ GECO (1983). Seismic Acquisition SurveyCanterbury Bight PPL38202, PPL38203. Petroleum Report Series PR 1053. Unpublished Petroleum Report, Ministry of Economic Development, New Zealand.

NZ GECO (1986). Seismic Survey Conducted In PPL 38202/203 Canterbury Bight 1982 and Reprocessed 1986. Petroleum Report Series PR 1203. Unpublished Petroleum Report, Ministry of Economic Development, New Zealand.

Pacrim Energy (1999). CB82 \& CB84 Reprocessing. Canterbury Bight. Petroleum Report Series PR 2575. Unpublished Petroleum Report, Ministry of Economic Development, New Zealand.

Pacrim Energy (1999). Seismic survey CB98 reportPEP 38254 \& 38255. Canterbury Bight. Petroleum Report Series PR 2474. Unpublished Petroleum Report, Ministry of Economic Development, New Zealand.

Prakla, S. G. (1998). Seismic survey, PEP 38256 , onshore Canterbury, IP256-98 lines. Petroleum Report Series PR 2391. Unpublished Petroleum Report, Ministry of Economic Development, New Zealand.

Ridd, M. F. (1963). The geology of the South Canterbury foothills between the Rakaia and Otaio Rivers. Petroleum Report Series PR 326. Unpublished Petroleum Report, Ministry of Economic Development, New Zealand.

Vaughan, E. (1974). Operational and final reports, detailed seismic survey, Canterbury Bight. Petroleum Report Series PR 634. Unpublished Petroleum Report, Ministry of Economic Development, New Zealand.

Warren, K. A. (1969). Interpretation of Seismic Data From Canterbury Plains Area Supplement. Petroleum Report Series PR 1216. Unpublished Petroleum Report, Ministry of Economic Development, New Zealand.

Western Geophysical Company (1982). Final Operation Report. Canterbury Bight. PPL's 38202 and 38203. Petroleum Report Series PR 898. Unpublished Petroleum Report, Ministry of Economic Development, New Zealand.

Western Geophysical Company (1983). Canterbury Bight PPL 38202/203 Seismic Data Reprocessed 1983. Petroleum Report Series PR 1054. Unpublished Petroleum Report, Ministry of Economic Development, New Zealand.

Western Geophysical Company (1984). Final report of operation \& field work marine seismic survey Canterbury Bight PPL 38023. Petroleum Report Series PR 1012. Unpublished Petroleum Report, Ministry of Economic Development, New Zealand. 
Wilson, C. J. (1990). Compilation of unpublished Paleontological Reports relevant to the Onshore \& Offshore Canterbury Basin Studies Region NZ. Petroleum Report Series PR 1497. Unpublished Petroleum Report, Ministry of Economic Development, New Zealand.
Woollands, M. A. (1978). An assessment of the hydrocarbon potential of the Great South Basin in relation to the offshore Canterbury Basin. Petroleum Report Series PR 1717. Unpublished Petroleum Report, Ministry of Economic Development, New Zealand. 


\section{Appendix D. Seismic lines}

This appendix gives a listing of the seismic surveys and the lines reviewed for this project.

\begin{tabular}{|c|c|c|c|c|c|}
\hline \begin{tabular}{|l} 
Survey \\
Name
\end{tabular} & $\begin{array}{l}\text { Line } \\
\text { Number }\end{array}$ & Processing Report & \begin{tabular}{|l|} 
Survey \\
Name
\end{tabular} & $\begin{array}{l}\text { Line } \\
\text { Number }\end{array}$ & Processing Report \\
\hline \multirow[t]{8}{*}{ A } & 34 & PR 292 & CB82 & 35 & PR 898 \\
\hline & 35 & Confidential Origin Reprocessed & (contd.) & 37 & PR 898 \\
\hline & 36 & Confidential Origin Reprocessed & & 38 & PR 898 \\
\hline & 37 & Confidential Origin Reprocessed & & 40 & PR 898 \\
\hline & 38 & Confidential Origin Reprocessed & & 41 & PR 898 \\
\hline & 39 & Confidential Origin Reprocessed & & 43 & PR 898 \\
\hline & 40 & Confidential Origin Reprocessed & & 44 & PR 898 \\
\hline & & & & 45 & PR 898 \\
\hline \multirow[t]{16}{*}{ ANZ } & 3 & Confidential Origin Reprocessed & & 46 & PR 898 \\
\hline & 4 & 2504 & & 48 & PR 898 \\
\hline & 5 & 2504 & & 53 & PR 898 \\
\hline & 6 & 2504 & & 56 & PR 898 \\
\hline & 7 & 2504 & & 57 & PR 898 \\
\hline & 8 & 2504 & & 58 & PR 898 \\
\hline & 1 & 2504 & & 60 & PR 898 \\
\hline & 9 & Confidential Origin Reprocessed & & 64 & PR 898 \\
\hline & 10 & Confidential Origin Reprocessed & & 66 & PR 898 \\
\hline & 11 & Confidential Origin Reprocessed & & 74 & PR 898 \\
\hline & 12 & Confidential Origin Reprocessed & & $78 a$ & PR 898 \\
\hline & 13 & Confidential Origin Reprocessed & & $80 a$ & PR 898 \\
\hline & 14 & Confidential Origin Reprocessed & & 82 & PR 898 \\
\hline & 15 & Confidential Origin Reprocessed & & 84 & PR 898 \\
\hline & 16 & Confidential Origin Reprocessed & & 86 & PR 898 \\
\hline & & & & 90 & PR 898 \\
\hline \multirow[t]{4}{*}{ B } & $210 B$ & Confidential Origin Reprocessed & & 92 & PR 898 \\
\hline & 34EXT & Confidential Origin Reprocessed & & 96 & PR 898 \\
\hline & 212B & Confidential Origin Reprocessed & & 98 & PR 898 \\
\hline & & & & 2 & Confidential Origin Reprocessed \\
\hline \multirow[t]{25}{*}{ CB82 } & 3 & PR 898 & & 4 & Confidential Origin Reprocessed \\
\hline & 4 & PR 898 & & 6 & Confidential Origin Reprocessed \\
\hline & 5 & PR 898 & & 8 & Confidential Origin Reprocessed \\
\hline & 6 & PR 898 & & 10 & Confidential Origin Reprocessed \\
\hline & 7 & PR 898 & & 110 & Confidential Origin Reprocessed \\
\hline & 100 & PR 898 & & 114 & Confidential Origin Reprocessed \\
\hline & 102 & PR 898 & & 11 & Confidential Origin Reprocessed \\
\hline & 104 & PR 898 & & 12 & Confidential Origin Reprocessed \\
\hline & 106 & PR 898 & & 14 & Confidential Origin Reprocessed \\
\hline & 108 & PR 898 & & 16 & Confidential Origin Reprocessed \\
\hline & 112 & PR 898 & & 17 & Confidential Origin Reprocessed \\
\hline & $18 \mathrm{a}$ & PR 898 & & 18 & Confidential Origin Reprocessed \\
\hline & 21 & PR 898 & & 19 & Confidential Origin Reprocessed \\
\hline & 22 & PR 898 & & 20 & Confidential Origin Reprocessed \\
\hline & 23 & PR 898 & & 25 & Confidential Origin Reprocessed \\
\hline & 24 & PR 898 & & 30 & Confidential Origin Reprocessed \\
\hline & $25 \mathrm{~A}$ & PR 898 & & 36 & Confidential Origin Reprocessed \\
\hline & 26 & PR 898 & & 42 & Confidential Origin Reprocessed \\
\hline & 27 & PR 898 & & $45 \mathrm{~A}$ & Confidential Origin Reprocessed \\
\hline & 28 & PR 898 & & 46 & Confidential Origin Reprocessed \\
\hline & 29 & PR 898 & & 47 & Confidential Origin Reprocessed \\
\hline & 31 & PR 898 & & $47 \mathrm{~b}$ & Confidential Origin Reprocessed \\
\hline & 32 & PR 898 & & 50 & Confidential Origin Reprocessed \\
\hline & 33 & PR 898 & & 51 & Confidential Origin Reprocessed \\
\hline & 34 & PR 898 & & $52 b$ & Confidential Origin Reprocessed \\
\hline
\end{tabular}




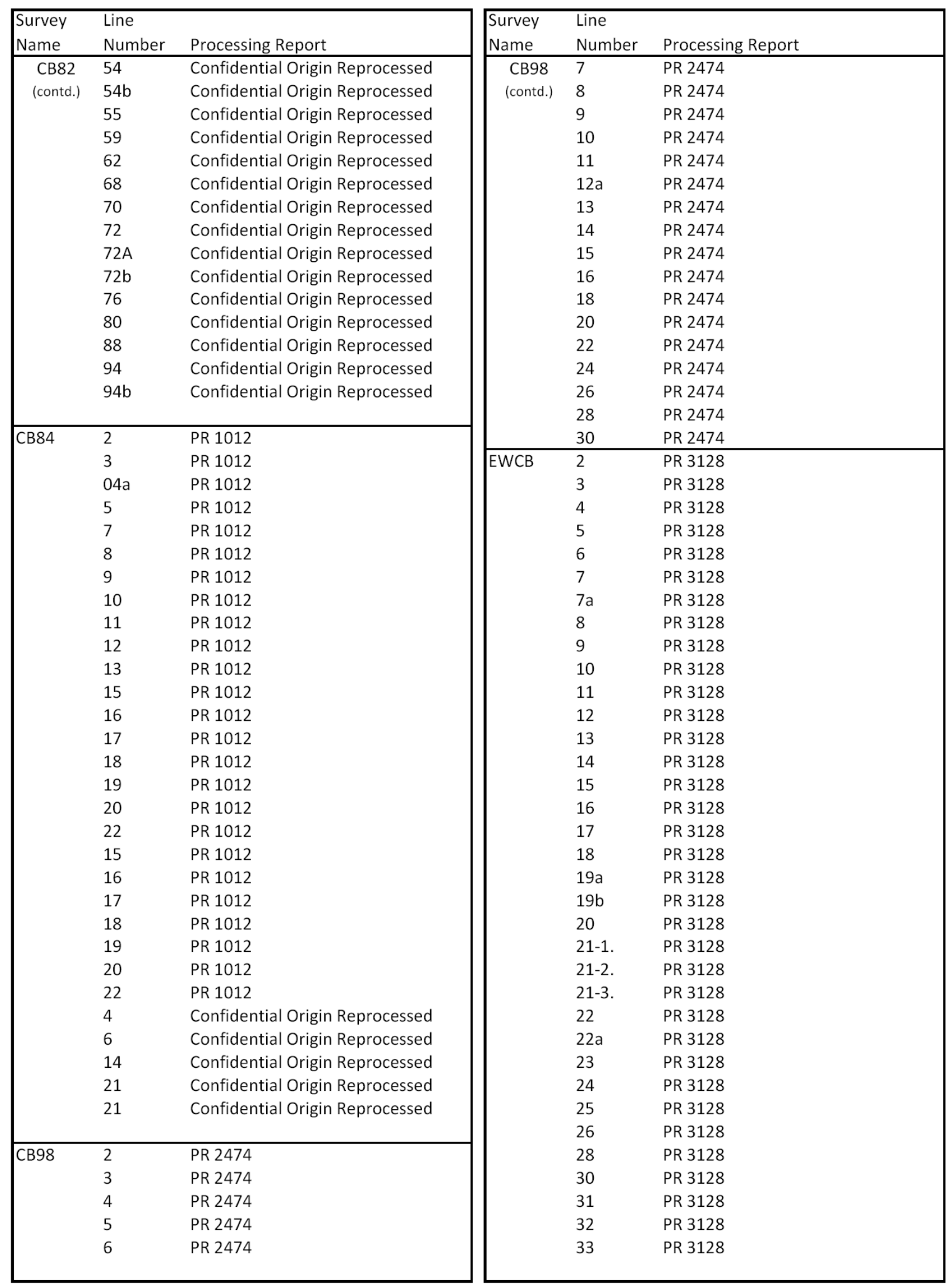




\begin{tabular}{|c|c|c|}
\hline \multirow{3}{*}{\begin{tabular}{|c}
$\begin{array}{l}\text { Survey } \\
\text { Name }\end{array}$ \\
$\begin{array}{c}\text { EWCB } \\
\text { (contd.) }\end{array}$
\end{tabular}} & Line & Processing Report \\
\hline & 34 & PR 3128 \\
\hline & $34 a$ & PR 3128 \\
\hline & 35 & PR 3128 \\
\hline & 36 & PR 3128 \\
\hline & 38 & PR 3128 \\
\hline & 40 & PR 3128 \\
\hline & $40 a$ & PR 3128 \\
\hline & 42 & PR 3128 \\
\hline & 44 & PR 3128 \\
\hline & 46 & PR 3128 \\
\hline & 48 & PR 3128 \\
\hline & 50 & PR 3128 \\
\hline & 52 & PR 3128 \\
\hline & 54 & PR 3128 \\
\hline & 56 & PR 3128 \\
\hline & 58 & PR 3128 \\
\hline & 60 & PR 3128 \\
\hline & 62 & PR 3128 \\
\hline & 64 & PR 3128 \\
\hline & 66 & PR 3128 \\
\hline & 68 & PR 3128 \\
\hline & 70 & PR 3128 \\
\hline & 72 & PR 3128 \\
\hline & 74 & PR 3128 \\
\hline & 76 & PR 3128 \\
\hline & 78 & PR 3128 \\
\hline & 80 & PR 3128 \\
\hline & 82 & PR 3128 \\
\hline & 84 & PR 3128 \\
\hline
\end{tabular}




\section{Appendix E. Well Data}

This appendix shows details of wells used in this study. All depths referred to are measured depth below rig datum (e.g. Kelly Bushing, Rotary Table or Drilling Floor)

General well data

\begin{tabular}{|c|c|c|c|c|c|c|c|c|}
\hline Well & PR & Year & Operator & NZMG E & NZMG N & TD & Target & Status \\
\hline Galleon-1 & 1146 & 1985 & $\begin{array}{l}\text { Shell BP } \\
\text { Todd } \\
\text { Canterbury } \\
\text { Services } \\
\text { Ltd }\end{array}$ & 512804 & 4962667 & 3086 & $\begin{array}{l}\text { Late } \\
\text { Cretaceous } \\
\text { Coal } \\
\text { Measures } \\
\text { Sandstones }\end{array}$ & $\begin{array}{l}\text { Plugged and } \\
\text { abandoned } \\
\text { as a gas } \\
\text { condensate } \\
\text { discovery }\end{array}$ \\
\hline Endeavour -1 & 303 & 1970 & $\begin{array}{l}\text { Shell BP } \\
\text { Todd } \\
\text { Canterbury } \\
\text { Services } \\
\text { Ltd }\end{array}$ & 467818 & 349420 & 2741 & $\begin{array}{l}1 . \\
\text { Oligocene- } \\
\text { Upper } \\
\text { Eocene } \\
\text { carbonate } \\
\text { and } \\
\text { diatomites } \\
\text { 2. Upper } \\
\text { Cretaceous } \\
\text { Coal } \\
\text { Measures }\end{array}$ & $\begin{array}{l}\text { Plugged and } \\
\text { abandoned } \\
\text { as a dry } \\
\text { hole. }\end{array}$ \\
\hline Clipper-1 & 1036 & 1984 & $\begin{array}{l}\text { Shell BP } \\
\text { Todd } \\
\text { Canterbury } \\
\text { Services } \\
\text { Ltd }\end{array}$ & 570693 & 5019828 & 4742 & $\begin{array}{l}\text { Upper } \\
\text { Cretaceous } \\
\text { Coal } \\
\text { Measures }\end{array}$ & $\begin{array}{l}\text { Plugged and } \\
\text { abandoned } \\
\text { with gas } \\
\text { condensate } \\
\text { shows }\end{array}$ \\
\hline Resolution-1 & 648 & 1975 & & 559336 & 476488 & 1963 & $\begin{array}{l}\text { Base } \\
\text { Tertiary/ } \\
\text { Upper } \\
\text { Cretaceous } \\
\text { Sandstones. }\end{array}$ & $\begin{array}{l}\text { Plugged and } \\
\text { abandoned } \\
\text { as a dry } \\
\text { hole. }\end{array}$ \\
\hline
\end{tabular}

b) Data collected and available over the Paleocene-Eocene interval of the Well

\begin{tabular}{|l|l|l|l|l|l|}
\hline Well & PR & $\begin{array}{l}\text { Conventional } \\
\text { Core }\end{array}$ & Sidewall Core & Wireline Logs & Biostratigraphy \\
\hline Galleon-1 & 1146 & No & Yes & Yes & Yes \\
\hline Endeavour-1 & 303 & No & Yes & Yes & Yes \\
\hline Clipper-1 & 1036 & No & Yes & Yes & Yes \\
\hline Resolution-1 & 648 & No & Yes & Yes & Yes \\
\hline
\end{tabular}




\section{Appendix F. Sidewall Core Descriptions and Photographs}

This appendix provides information and photographs of each of the cores described in this study. The sidewall cores described were selected from the Paleocene section at all four wells. Samples were also collected from the Lower Eocene and Upper Cretaceous intervals to put the changes in lithology within the Paleocene interval into context. Eocene sidewall core samples were selected on the basis of them being representative of the formations present within the Eocene. Upper Cretaceous samples were selected to observe facies changes over the Cretaceous-Paleocene boundary. These core intervals described are:

Galleon $-1 \quad 2163 \mathrm{~m}-2690.2 \mathrm{~m}$

Endeavour-1 1594.10m-1984.24m

Resolution-1 1462m-1740m

All depths referred to are Measured Depths (MD) below Rotary Table (RT) or Kelly Bushing (KB)

Sedimentological descriptions and photographs were done by Sanjay Samuel, Cliff Atkins and Malcolm Arnot (Geologists). 
Well: Galleon-1

\begin{tabular}{|c|c|c|}
\hline $\begin{array}{l}\text { Sample No } \\
\text { (m brt) }\end{array}$ & Core Description & $\begin{array}{l}\text { Photo } \\
\text { No. }\end{array}$ \\
\hline 2163 & $\begin{array}{l}\text { Mudstone-light grey/ green to medium grey, firm, homogeneous, (very } \\
\text { calcareous grades to argillaceous limestone) }\end{array}$ & 1 \\
\hline 2197.6 & $\begin{array}{l}\text { Mudstone-light grey/ green to medium grey, firm, homogeneous, (very } \\
\text { calcareous) }\end{array}$ & \\
\hline 2259.1 & Mudstone-light to medium blue grey, as above & \\
\hline 2320.8 & As above, with glauconite grains & 2 \\
\hline 2381 & $\begin{array}{l}\text { Mudstone-medium to dark grey, soft to firm, sub-fissile, slightly to } \\
\text { moderately calcareous. }\end{array}$ & \\
\hline 2396.3 & As above & \\
\hline 2402 & As above & \\
\hline 2502 & Empty & \\
\hline 2506.5 & Mudstone-dark brown, organic rich, silty, occasional glauconite pellets. & \\
\hline 2512.4 & $\begin{array}{l}\text { Mudstone-dark brown-grey, organic rich, slight oily odour (may have } \\
\text { generated hydrocarbons?) }\end{array}$ & 3 \\
\hline 2519.5 & $\begin{array}{l}\text { Mudstone-dark grey, firm, fissile, non calcareous, organic rich, slight } \\
\text { oily odour (may have generated hydrocarbons?) }\end{array}$ & \\
\hline 2533.5 & Lost & \\
\hline 2559.2 & $\begin{array}{l}\text { Mudstone-medium brown grey, firm to hard, slightly organic }(\sim 1 \%) \text {, } \\
\text { micromicaceous, fissile to sub fissile, slightly calcareous/ dolomitic. }\end{array}$ & 4 \\
\hline 2595 & $\begin{array}{l}\text { Mudstone-medium to dark grey, firm to hard, fissile to sub fissile, } \\
\text { slightly calcareous/ dolomitic, occasionally silty. }\end{array}$ & \\
\hline 2629.7 & Lost & \\
\hline 2690.2 & $\begin{array}{l}\text { Silty mudstone, medium to dark grey, firm to hard, sub fissile, slightly } \\
\text { calcareous/ dolomitic. }\end{array}$ & 5 \\
\hline
\end{tabular}




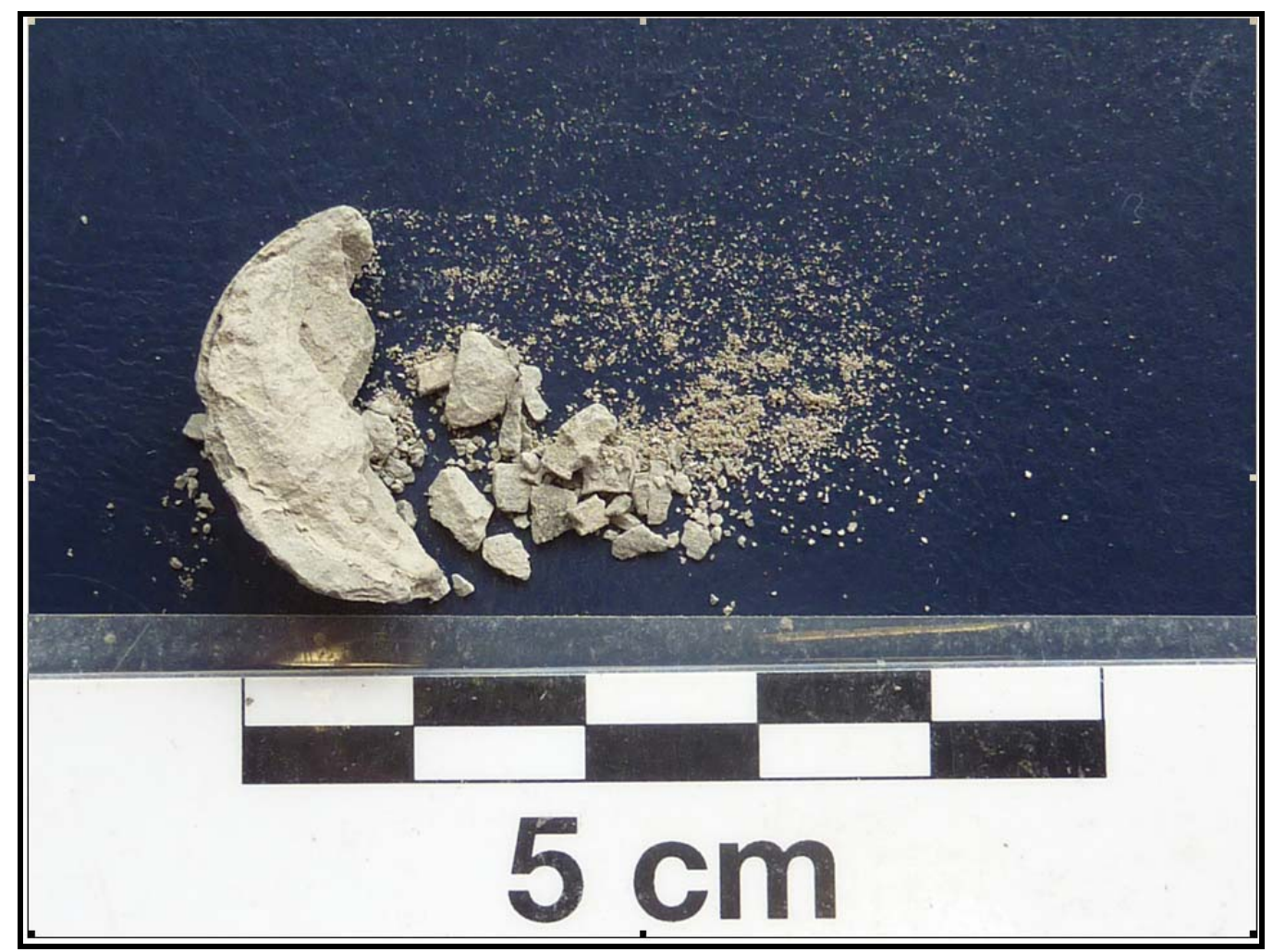

Figure 1

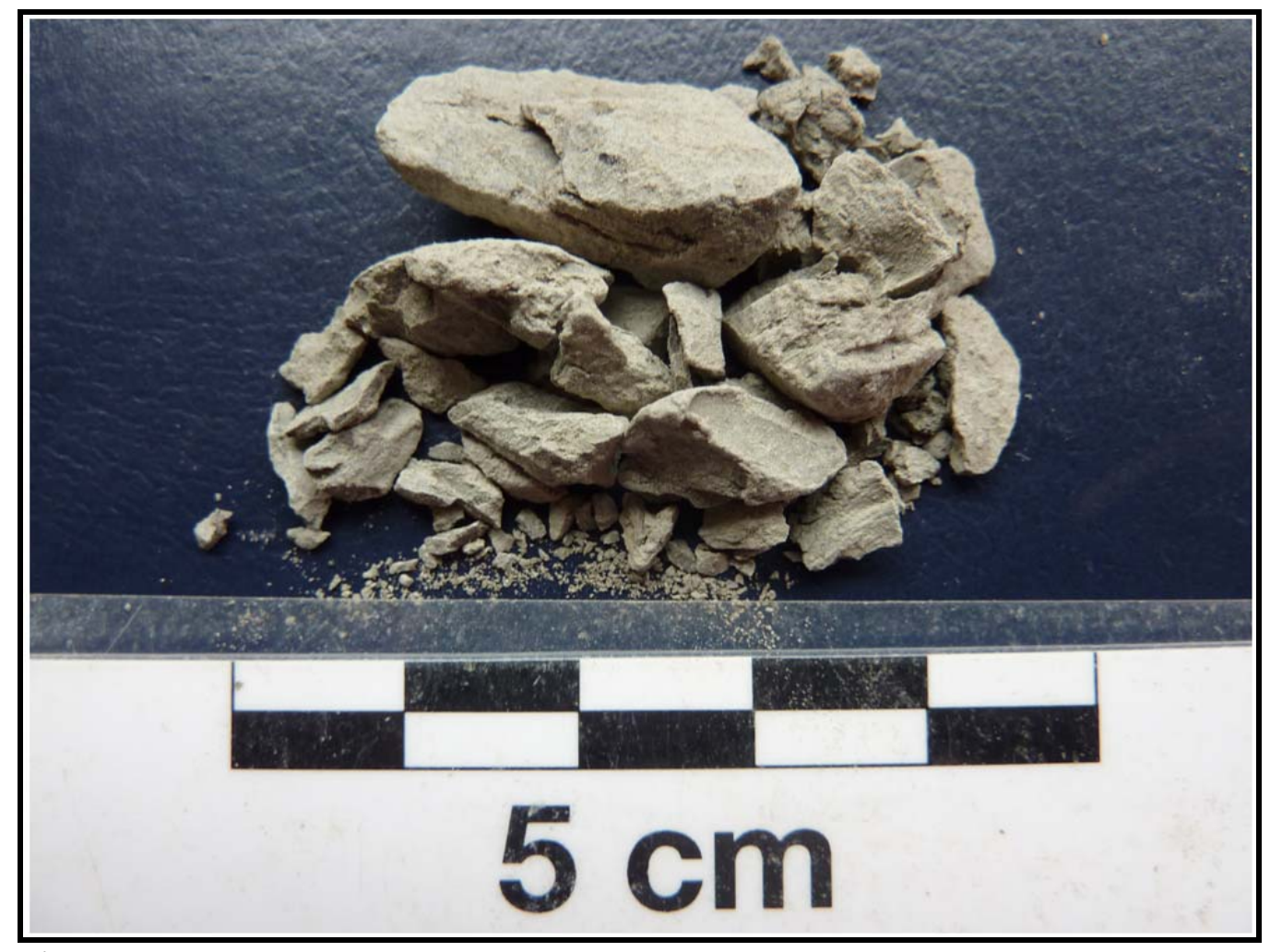

Figure 2 


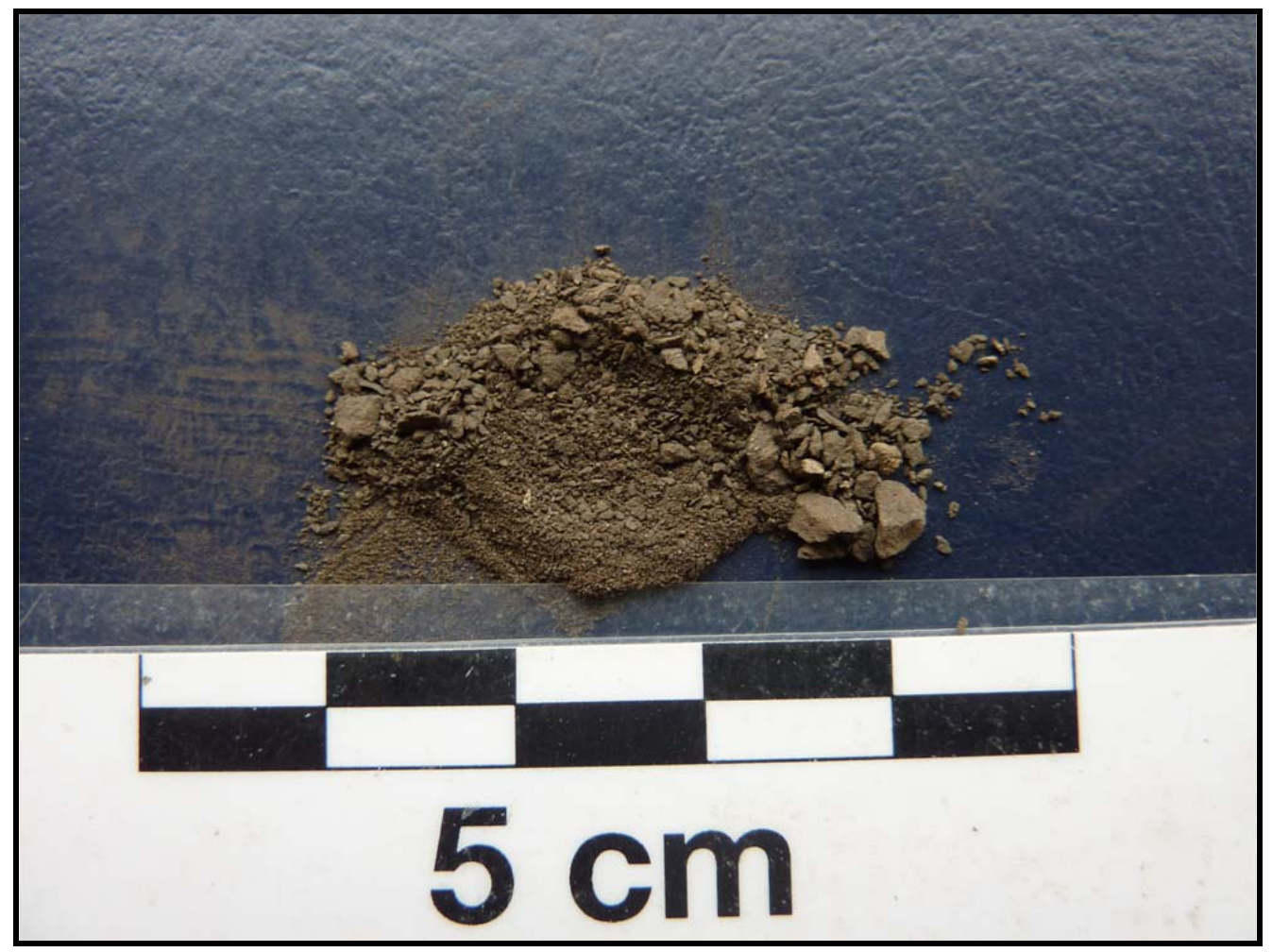

Figure 3

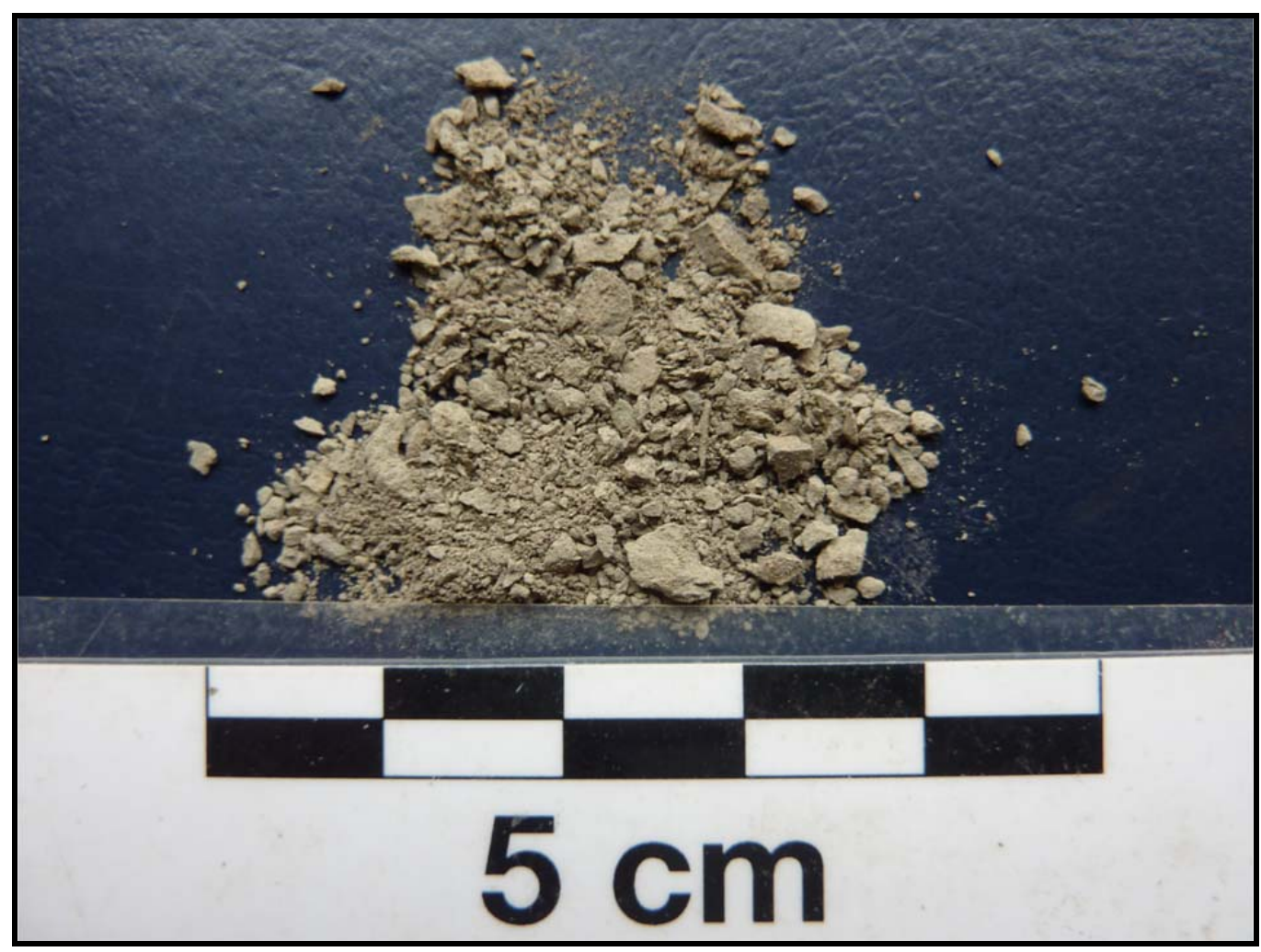

Figure 4 


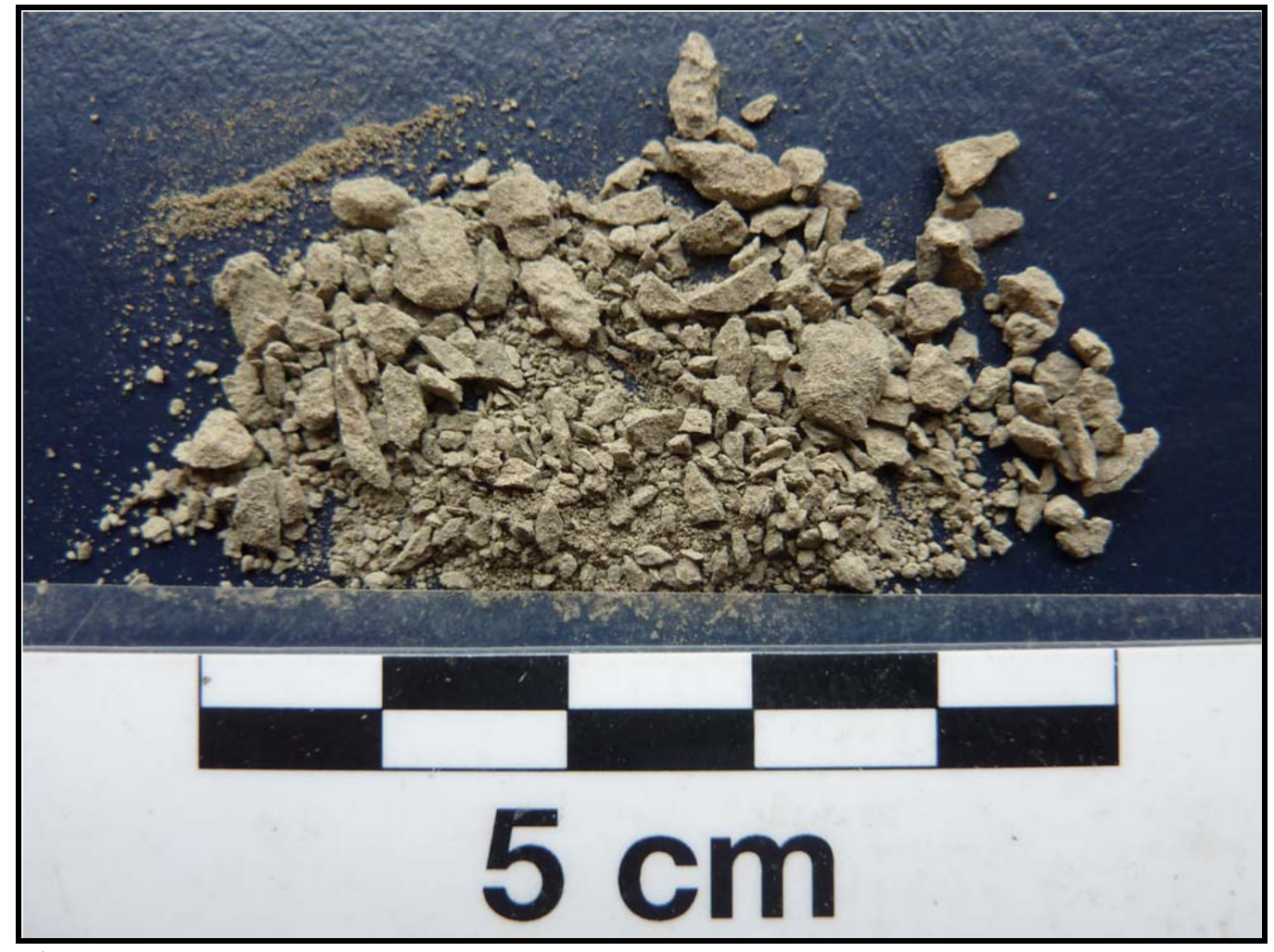

Figure 5 


\section{Well: Endeavour-1}

\begin{tabular}{|c|c|c|}
\hline $\begin{array}{l}\text { Sample No. } \\
\text { (m bdf) }\end{array}$ & Core Description & $\begin{array}{l}\text { Photo } \\
\text { No. }\end{array}$ \\
\hline 1594.10 & $\begin{array}{l}\text { Mudstone, Pale light brown grey, massive, homogenous, isolated organic } \\
\text { material 1-4 mm (different from Galleon-1 Hampden Formation by being } \\
\text { slightly brown grey) }\end{array}$ & 6 \\
\hline 1615.44 & $\begin{array}{l}\text { Muddy siltstone, light-medium grey, with a pyrite nodule and a few mica } \\
\text { flakes, massive }\end{array}$ & 7 \\
\hline 1636.77 & Silty mudstone, medium-dark grey, slightly fissile & \\
\hline 1648.96 & $\begin{array}{l}\text { Muddy siltstone (same as } 5300 \mathrm{~m} \text { ), contains pyrite flakes, slightly } \\
\text { micaceous }\end{array}$ & \\
\hline 1676.4 & Silty mudstone, medium-dark grey, slightly fissile & \\
\hline 1719 & As above & \\
\hline 1734.3 & Slightly sandy mudstone (sandy laminations), very dark grey & 8 \\
\hline 1737.3 & As above & \\
\hline 1752.6 & Missing & \\
\hline 1767.84 & Muddy siltstone, medium grey, slightly fissile, micaceous & \\
\hline 1786.12 & $\begin{array}{l}\text { Very fine sandstone, blue grey, extremely hard and cemented, quartz veins } \\
\text { present, glauconite } \\
\text { NOTE-another lithology was encountered within the same bottle } \\
\text { very fine sandy siltstone, slightly brown grey }\end{array}$ & 9 \\
\hline 1798.32 & Muddy siltstone, medium grey (similar to 5300) & \\
\hline 1859.28 & $\begin{array}{l}\text { Dark green basalt, crumbly, abundant steam cavities, analcime matrix with } \\
\text { some cavities, occassional xenoliths of muddy siltstone }\end{array}$ & 10 \\
\hline 1903.47 & Silty mudstone & \\
\hline 1929.38 & As above & \\
\hline 1984.24 & $\begin{array}{l}\text { Very fine silty sand, medium brown grey, uncemented, unlithified, } \\
\text { moderately sorted. }\end{array}$ & \\
\hline
\end{tabular}




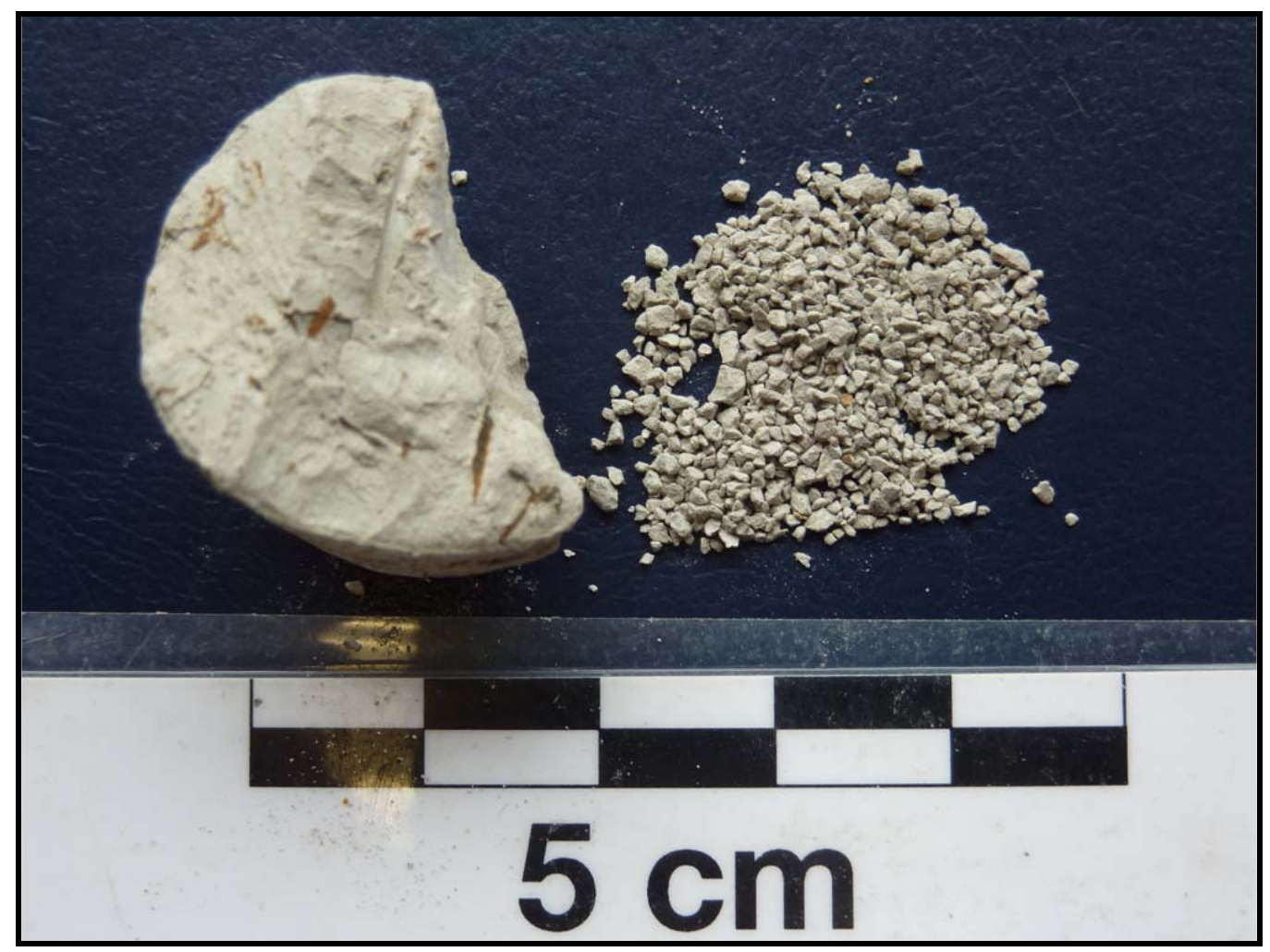

Figure 6

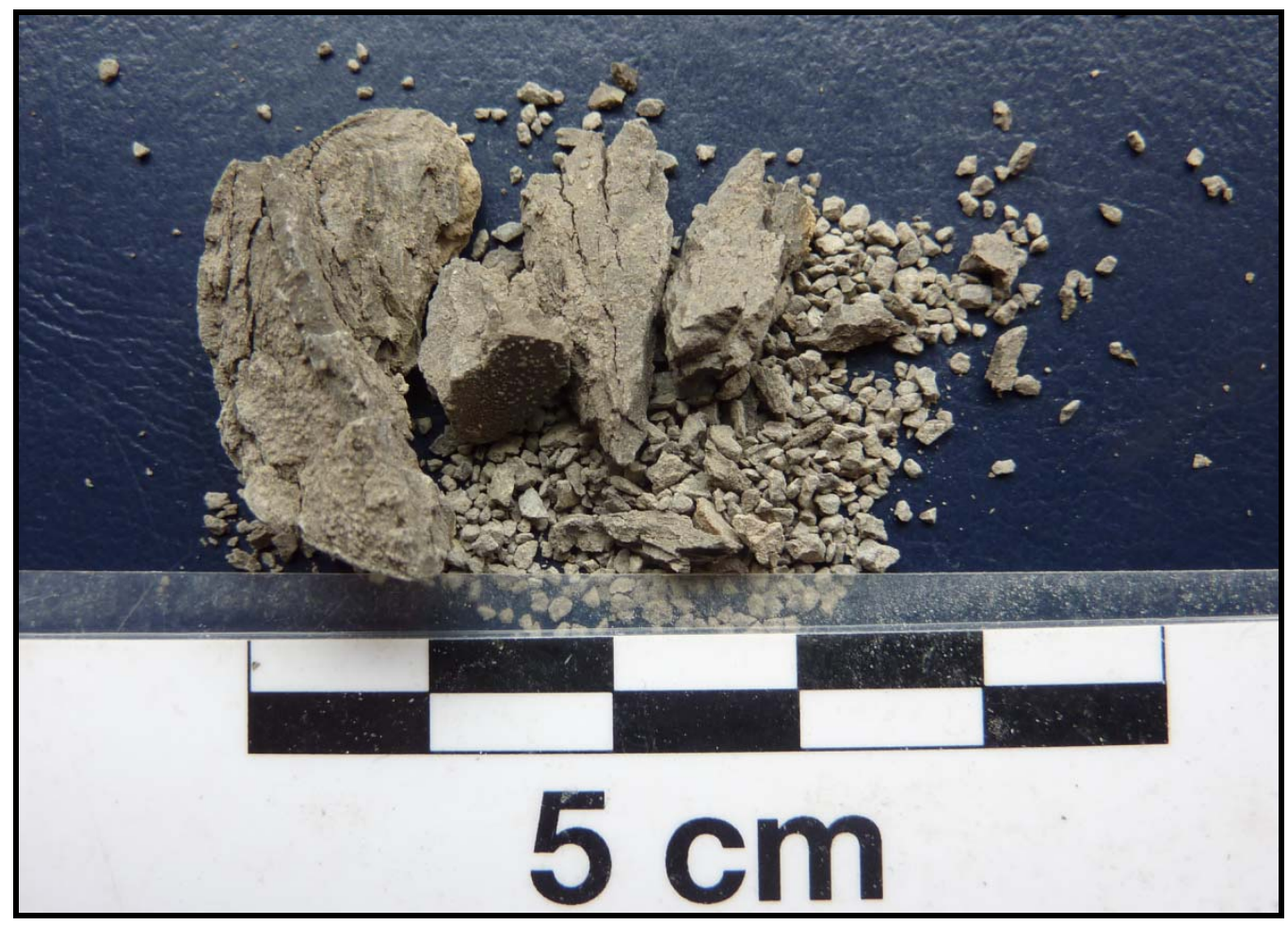

Figure 7 


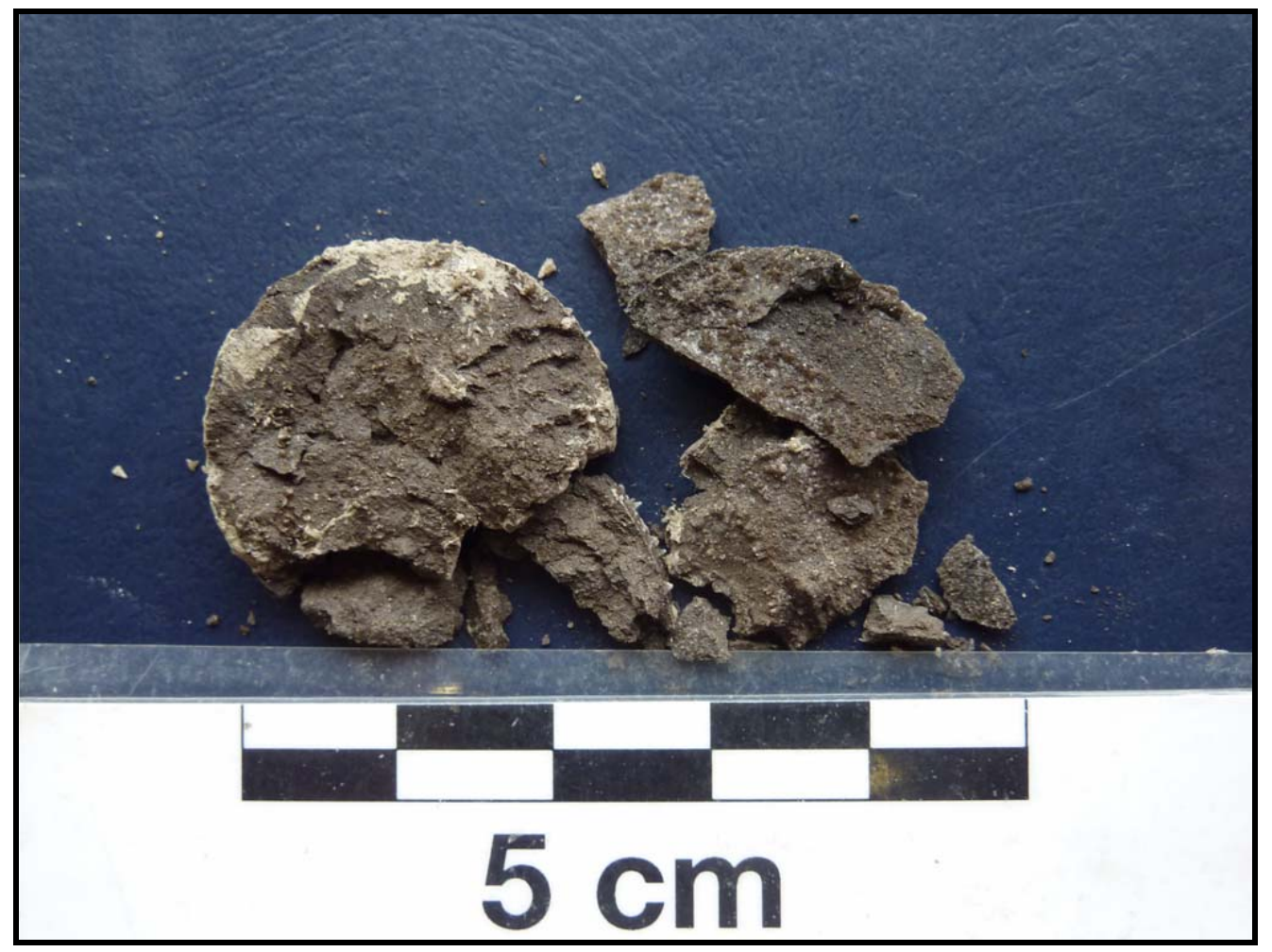

Figure 8

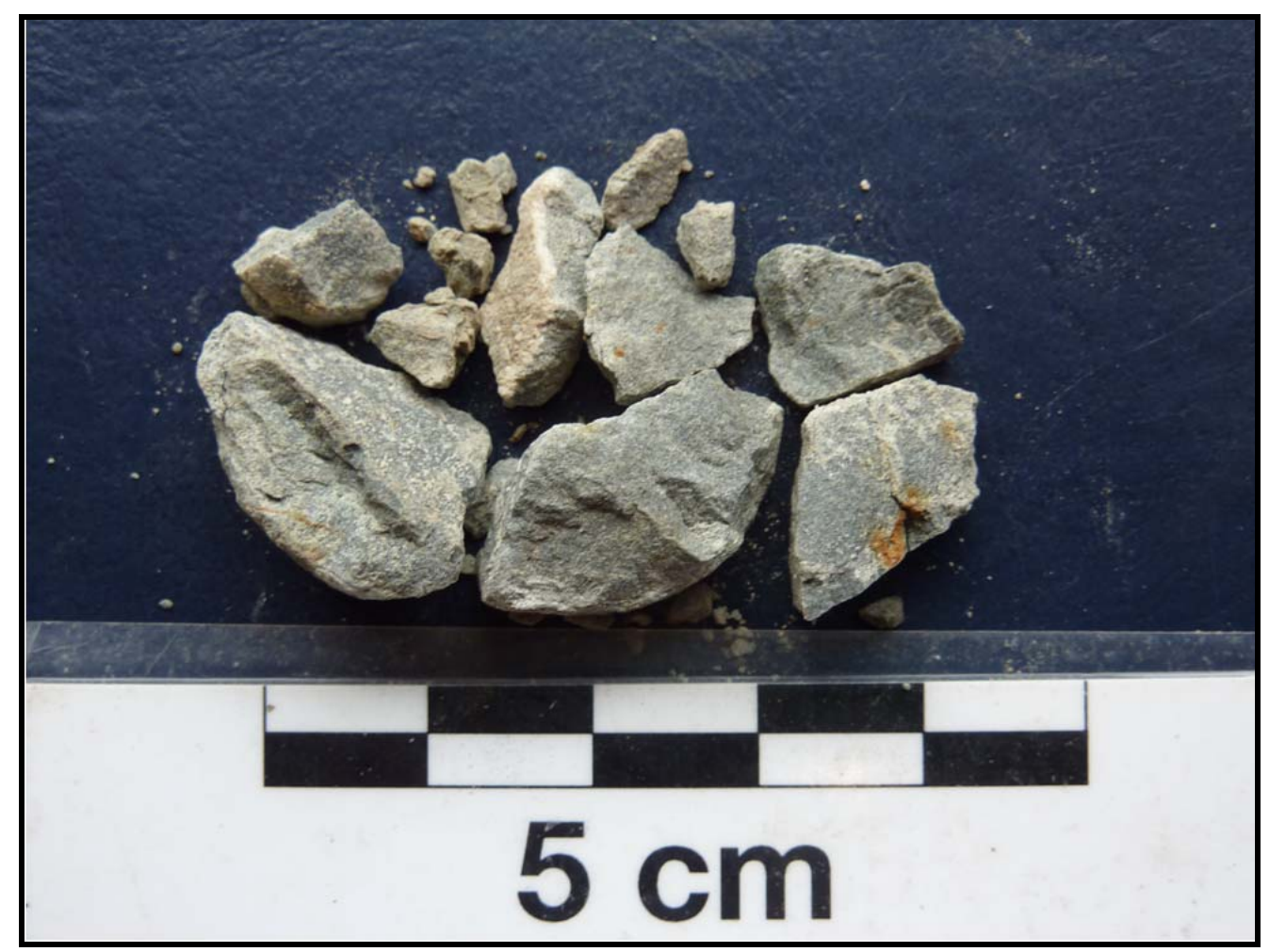

Figure 9 


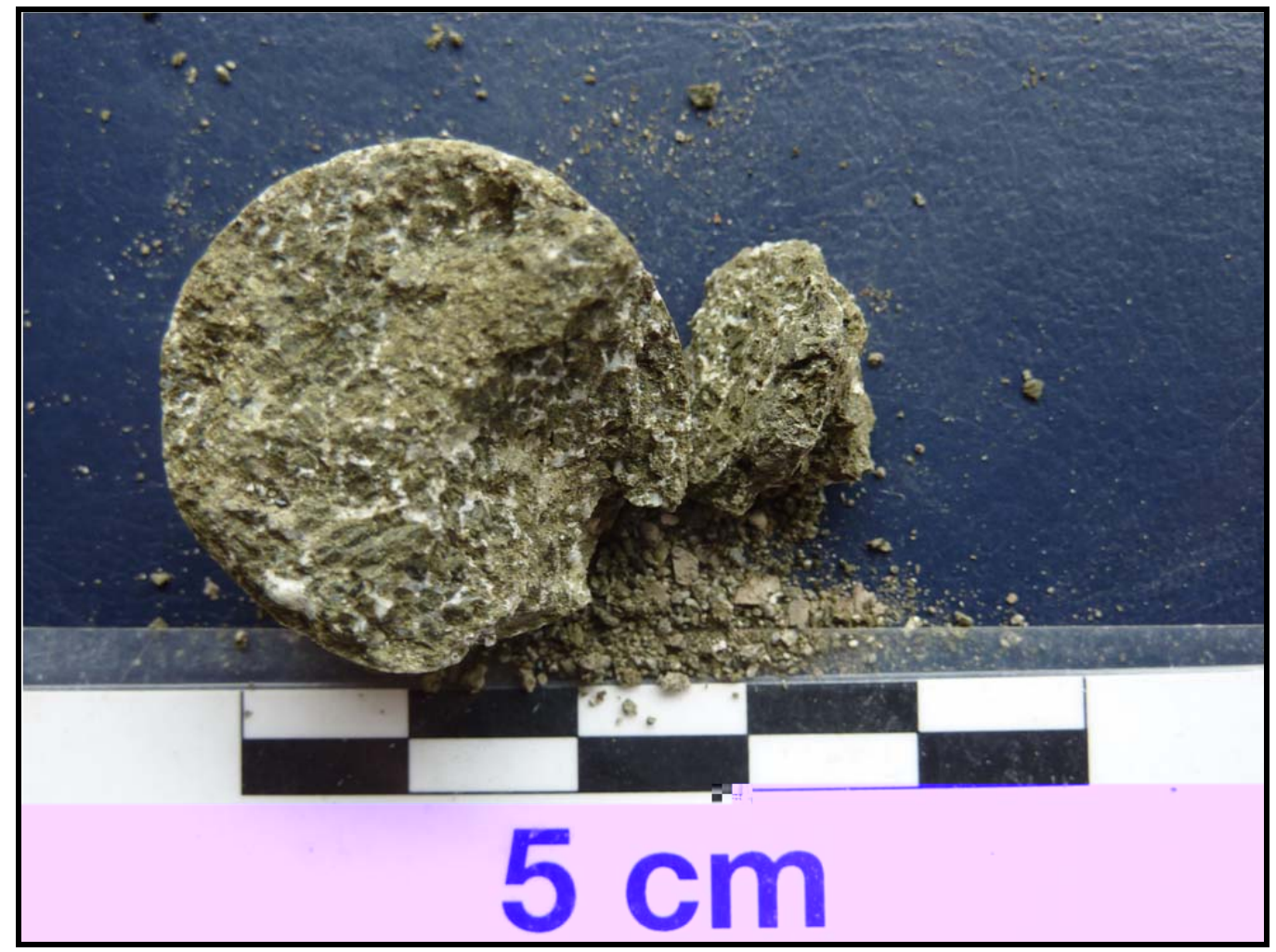

Figure 10 
Well: Resolution-1

\begin{tabular}{|c|c|c|}
\hline $\begin{array}{c}\text { Sample No. } \\
\text { (m bkb) }\end{array}$ & Core Description & $\begin{array}{c}\text { Photo } \\
\text { No. }\end{array}$ \\
\hline 1462 & $\begin{array}{l}\text { Silty mudstone, massive, medium-dark grey, elongated organic fragments } \\
\text { upto } 5 \mathrm{~mm} \text {, some glauconite grains. }\end{array}$ & 11 \\
\hline 1474 & Dark green grey silty mudstone, same as above & \\
\hline 1478 & Same as above & 12 \\
\hline 1480 & $\begin{array}{l}\text { Fine sandstone, very green, green streak with knife, mottled with orange } \\
\text { from glauconite }\end{array}$ & 13 \\
\hline 1510 & $\begin{array}{l}\text { Very fine-fine sandstone, light-medium yellow brown, moderately well } \\
\text { sorted, friable }\end{array}$ & 14 \\
\hline 1525 & $\begin{array}{l}\text { Very fine- fine sandstone, very light white brown, moderately sorted, } \\
\text { friable }\end{array}$ & 15 \\
\hline 1528 & As above, slightly more yellow (very light brown) & \\
\hline 1532 & As above & \\
\hline 1534 & As above & \\
\hline 1546 & As above & \\
\hline 1557 & As above, light brown sand & \\
\hline 1560 & $\begin{array}{l}\text { Sandstone, brownish green, very poorly sorted with angular fragments upto } \\
2 \mathrm{~mm}\end{array}$ & 16 \\
\hline 1562 & As above & \\
\hline 1566 & As above & \\
\hline 1567.5 & As above & \\
\hline 1572 & Very fine-fine sand, light brown grey, same as $1510 \mathrm{~m}$. & \\
\hline 1574.4 & As above & \\
\hline 1579 & $\begin{array}{l}\text { Very fine-medium sandstone, light white brown, very poorly sorted, } \\
\text { friable }\end{array}$ & \\
\hline 1581 & As above, light brown & 17 \\
\hline 1590 & As above & \\
\hline 1610 & Very fine-fine sandstone, same as 1525 & \\
\hline 1640 & As above, slightly darker with some glauconite grains & \\
\hline 1668 & As above & \\
\hline 1685 & As above & \\
\hline 1740 & Very fine-fine sand, light brown, friable, moderately sorted & \\
\hline
\end{tabular}




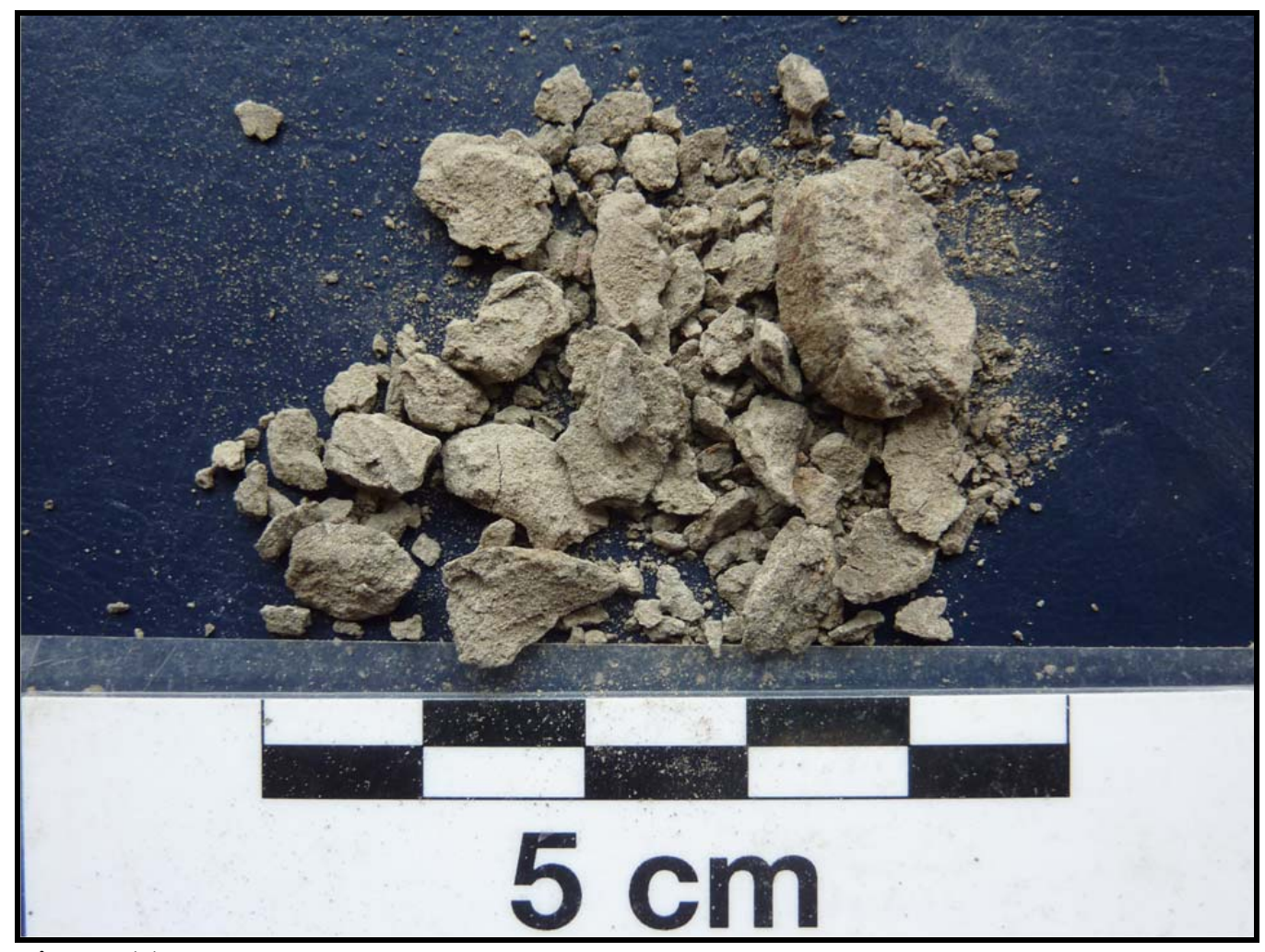

Figure 11

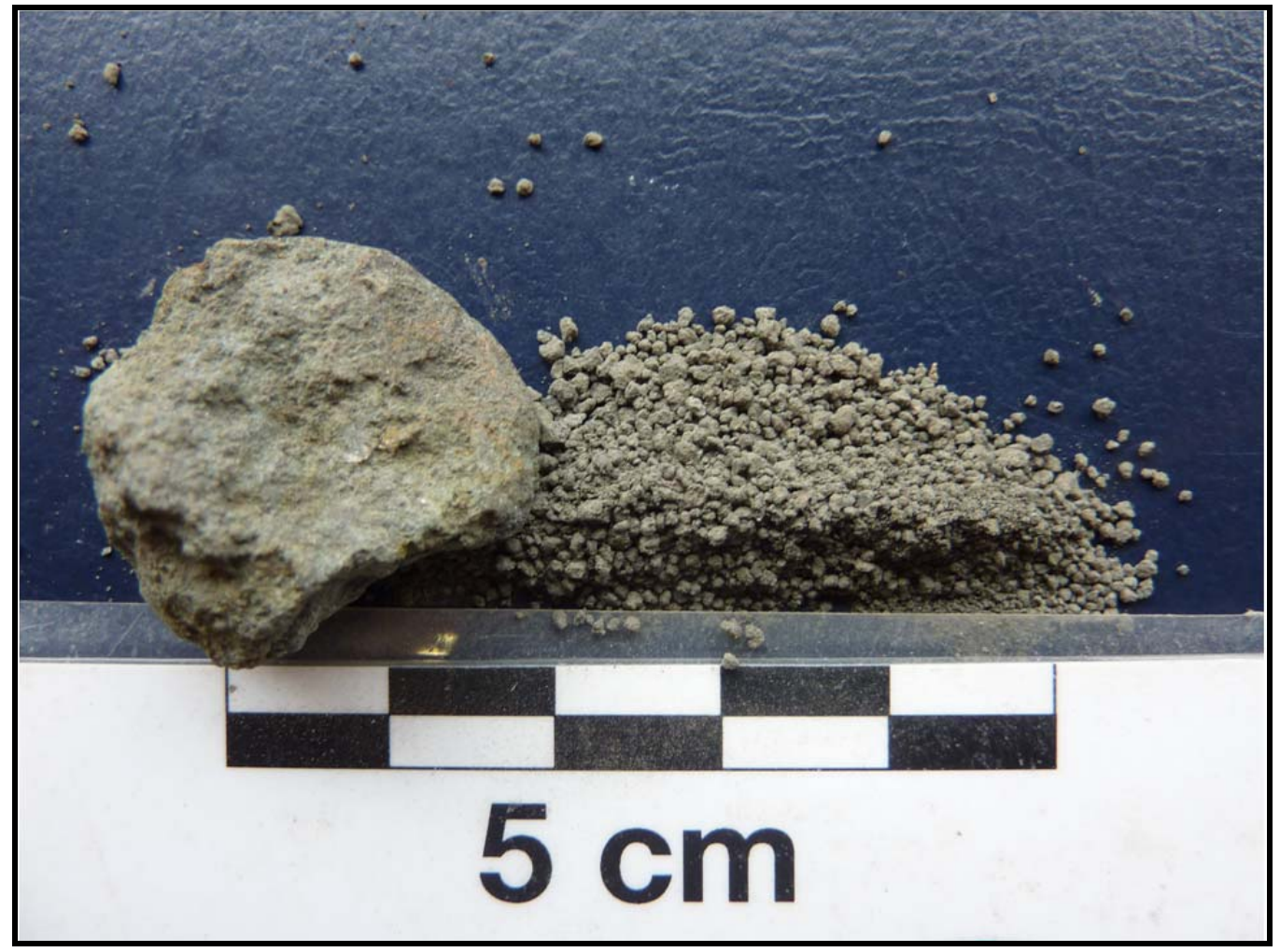

Figure 12 


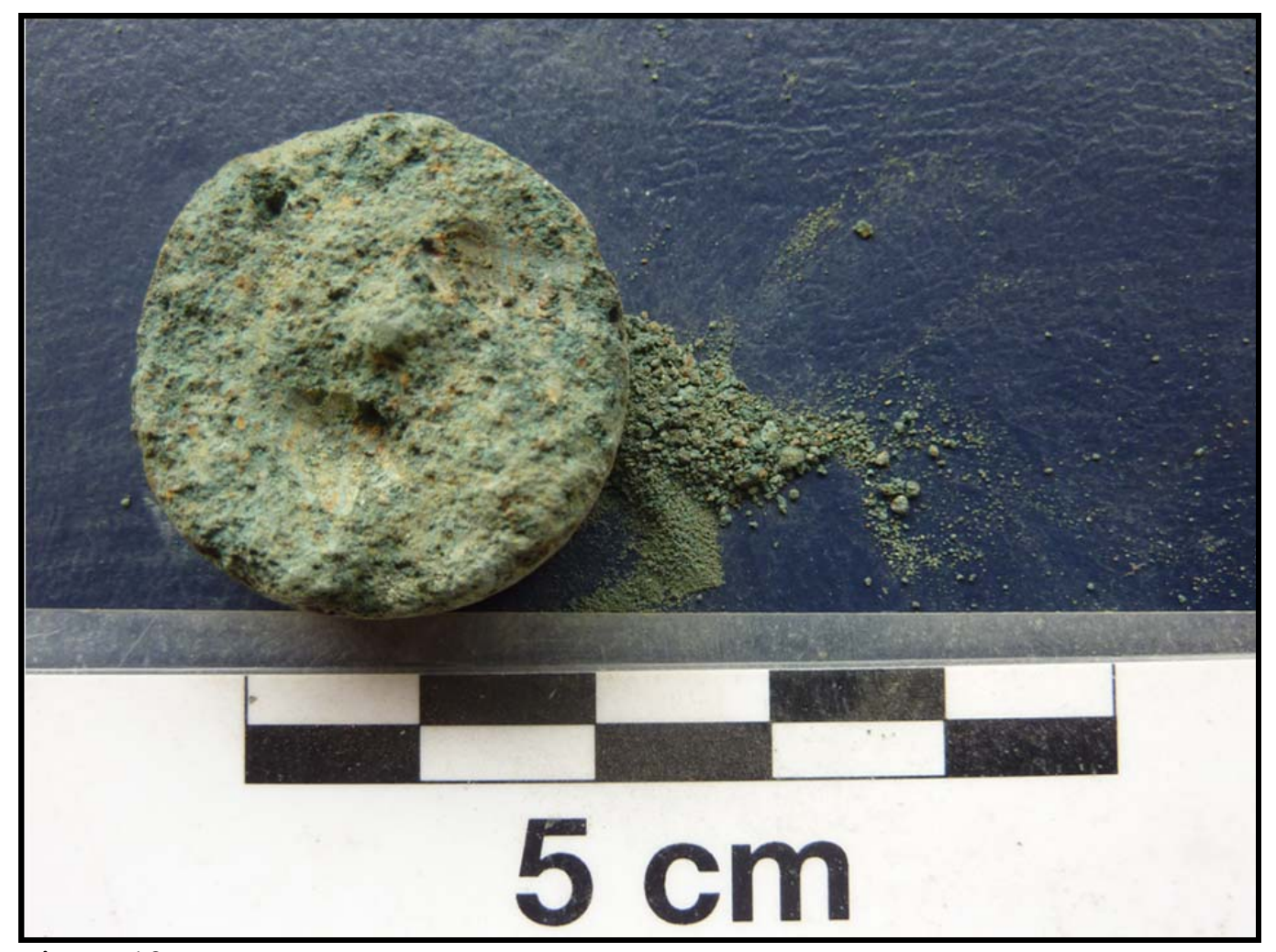

Figure 13

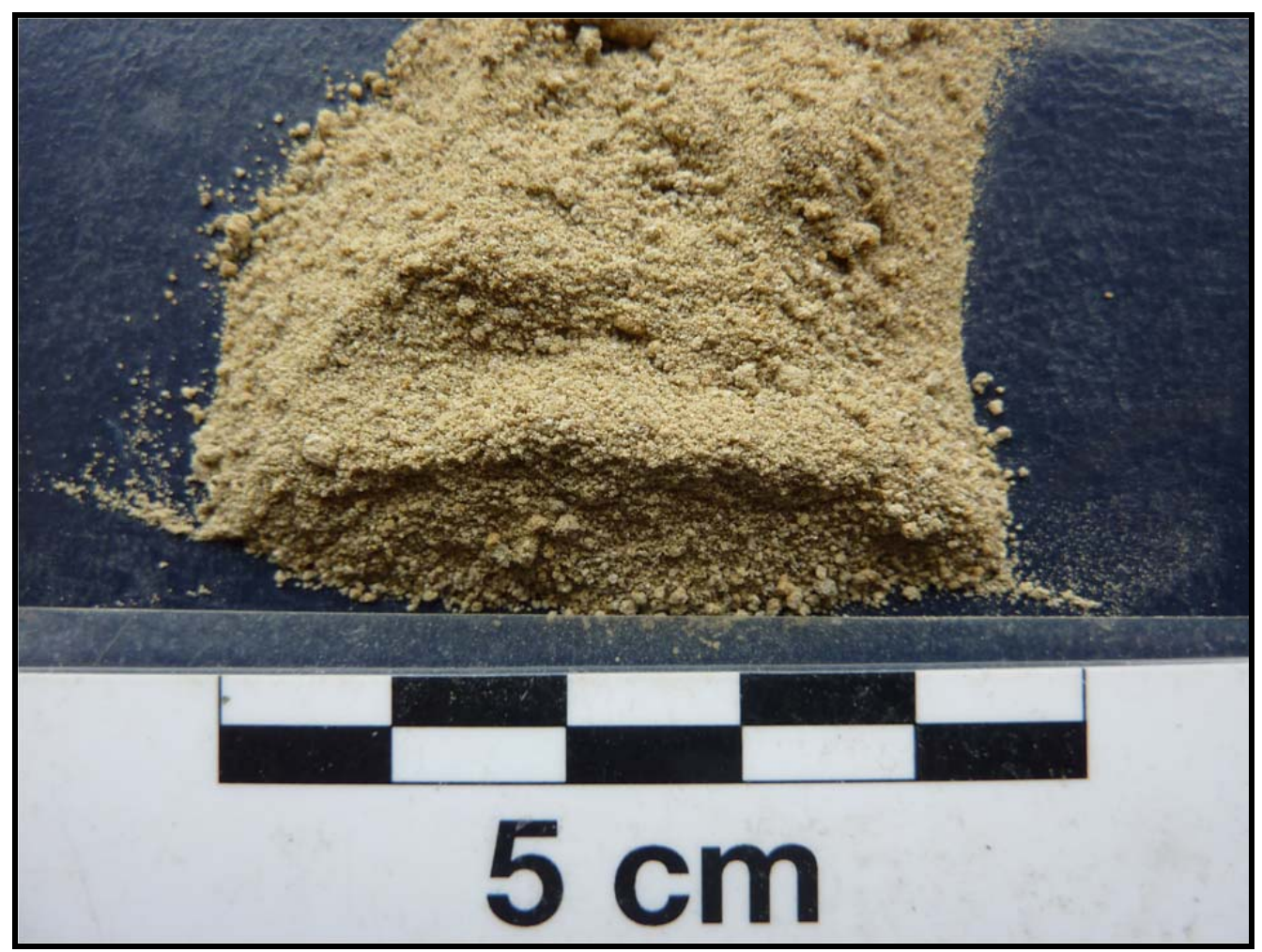

Figure 14 


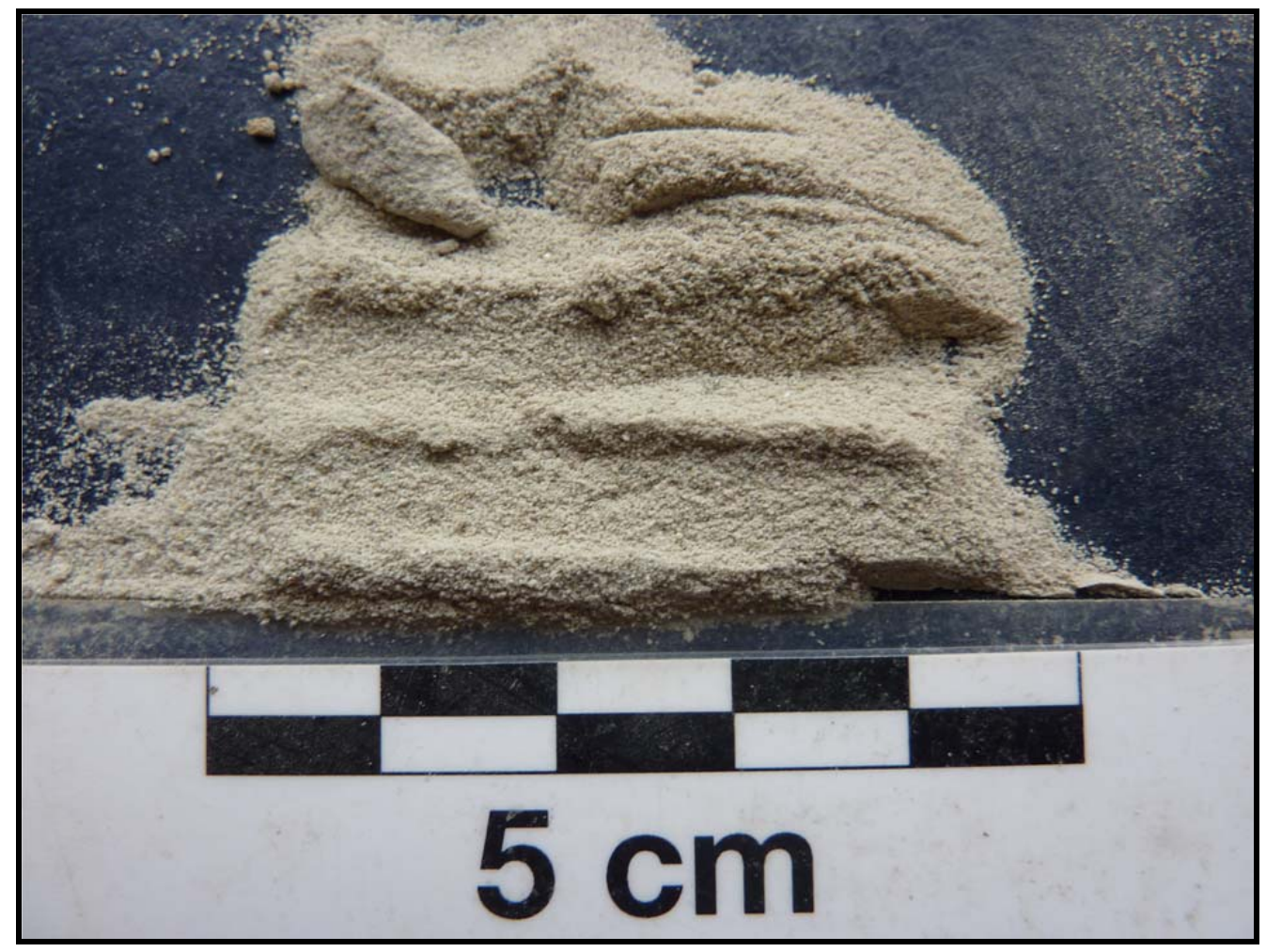

Figure 15

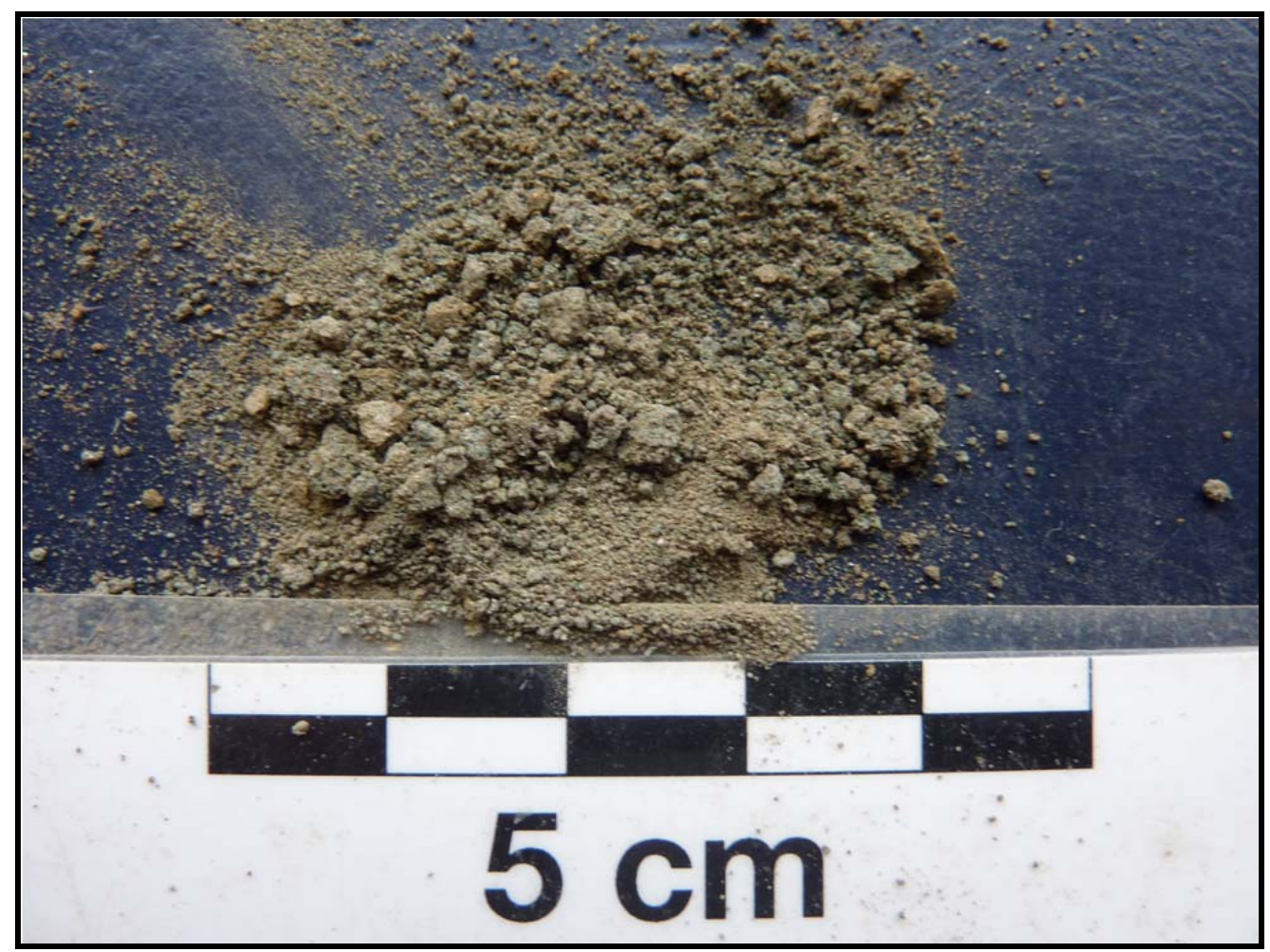

Figure 16 


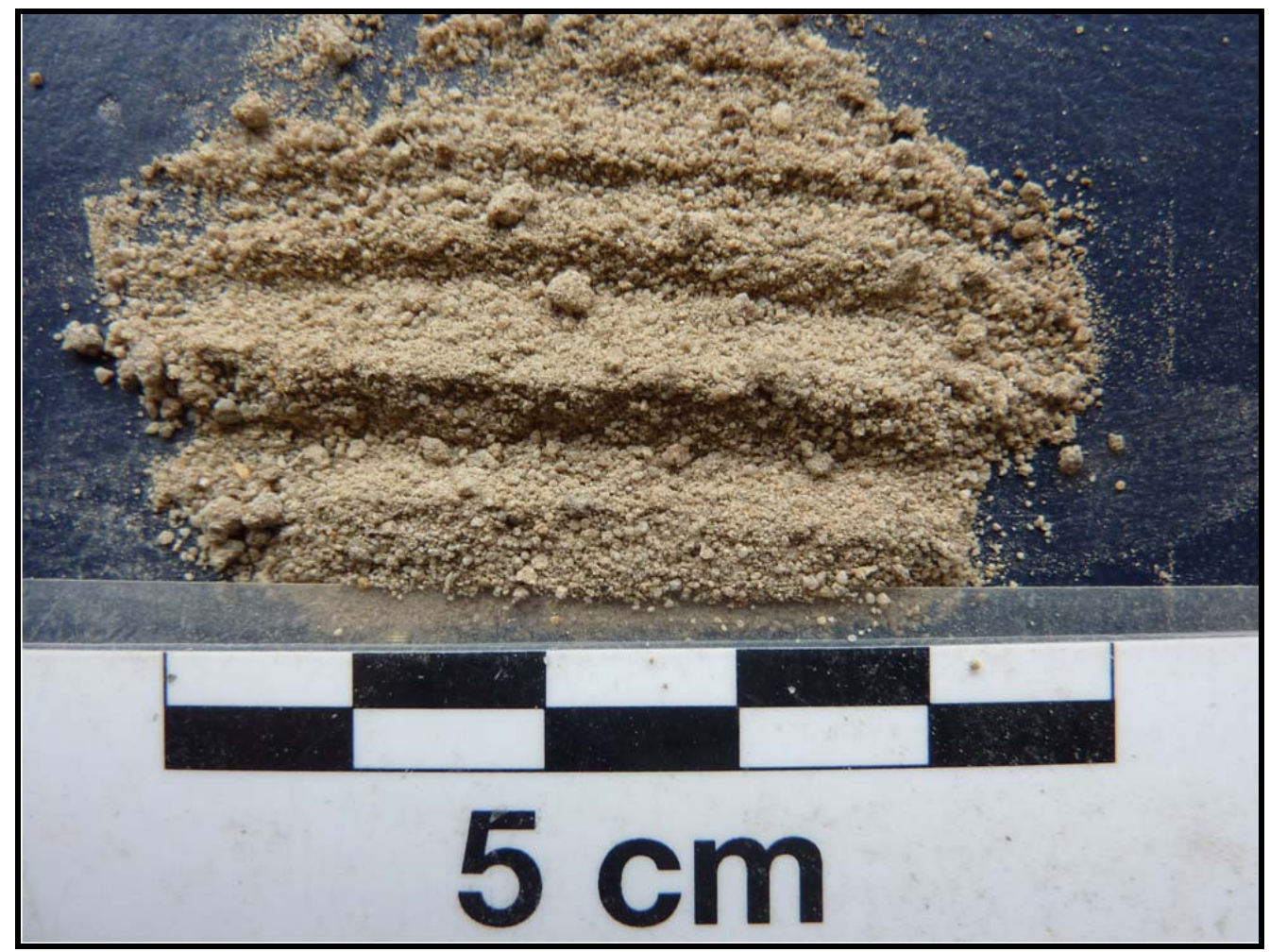

Figure 17 


\section{Appendix G. Well Sheets}

Well sheets for the four offshore wells Galleon-1, Endeavour-1, Clipper-1 and Resolution-1 drilled in the study area are presented at a 1:5000 scale for the Paleocene to Eocene interval, with depth, wireline logs, original stratigraphic information from the well completion reports, biostratigraphy, lithology, revised stratigraphy and paleoenvironmental interpretation. Location of wells is presented in Figure 1. Data used for the construction of these well sheets were from open file petroleum and biostratigraphic reports, and a review of the data in this study. Paleoenvironmental interpretation was from GNS, (2009). A key for the well sheets is presented over leaf.

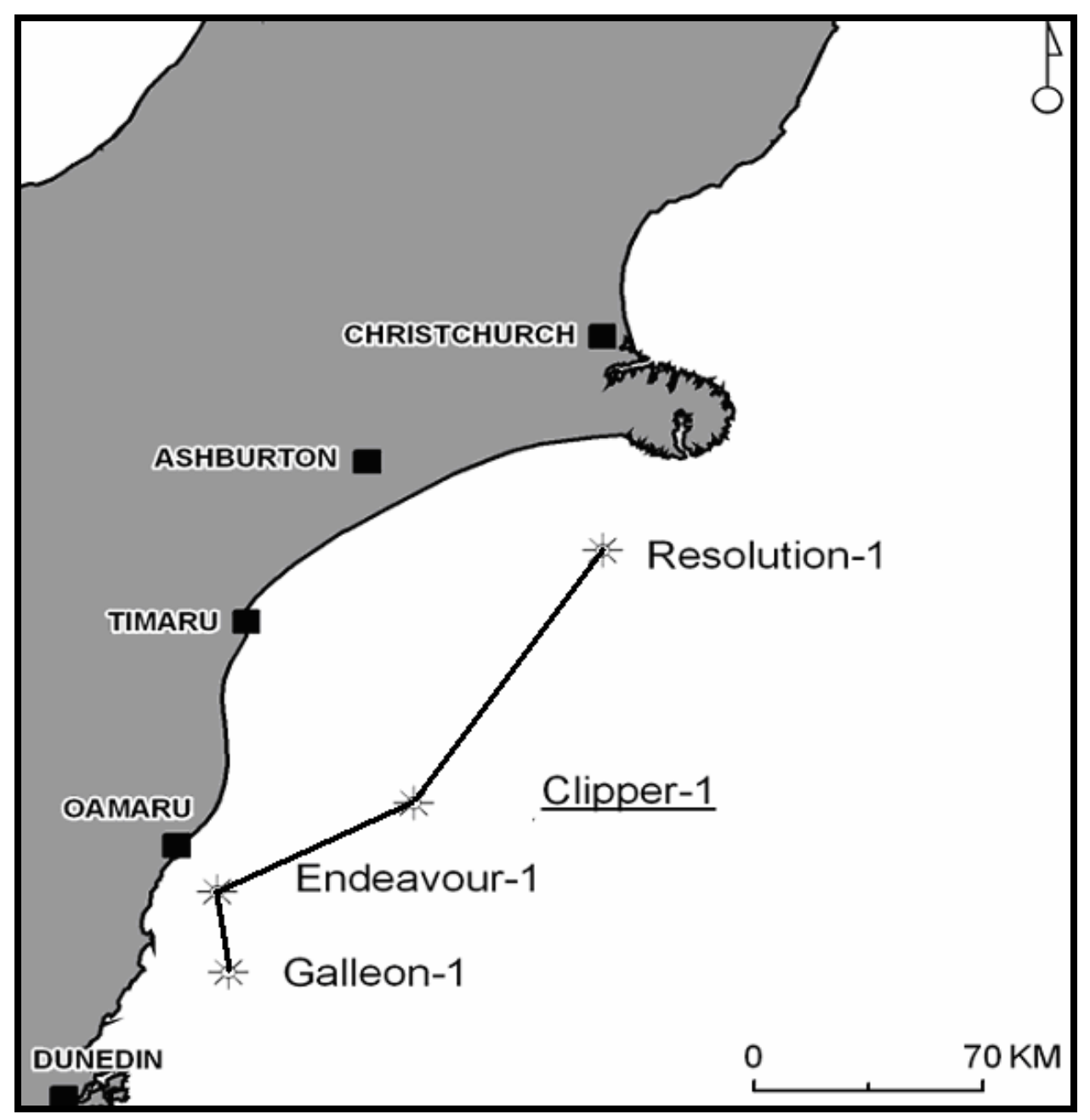

Figure 1: Location map of wells in this appendix. 


\section{Key for well sheets}

Track 1 Depth m below rotary table (RT) or kelly bushing (KB)

Track 2 Well deviation

Track 3 Casing points

Track 4 Caliper (red), gamma ray (black)

Track 5 Resistivity logs

Track 6 Sonic (blue), spontaneous potential (green)

Track 7 Neutron (blue), density (red), photoelectric log (black)

Track 8 Original Stratigraphy from PR-Group/ Formation

Track 9 Original Stratigraphy from PR-Biostratigraphy

Track 10 Original Stratigraphy from PR-Epoch

Track $11 \quad$ Lithology

Track 12 Revised Stratigraphy- Revised Group/ Formation Epoch

Track 13 Revised Stratigraphy- Paleontology sample depth

Track 14 Revised Stratigraphy-Biostratigraphy

Track 15 Revised Stratigraphy-Revised Epoch

Track 16 Paleoenvironment 


\section{GALLEON-1}

Country: New Zealand

Location: Canterbury

Latitude: $45^{\circ} 29^{\prime} 18.82 " \mathrm{~S} \quad$ Longitude: $171^{\circ} 09^{\prime} 49.84 " \mathrm{E}$

New Zealand Map Grid Y:5 522900.6 m NX: 2366381.5 m E

Spud Date: 15/09/1985

Directional Data: Near vertical well

Operator: Shell, BP \& Todd Oil Services Ltd

Petroleum Report: 1146

Scale: $1: 5,000$
Total Depth: $3086 \mathrm{~m}$ brt

Ground Level Elevation: -90.8 m bmsl

Rotary Table Elevation: $27.1 \mathrm{~m}$ amsl

Status: Plugged and abandoned

Hydrocarbon Shows: Gas/condensate

Edited by: Sanjay Samuel 


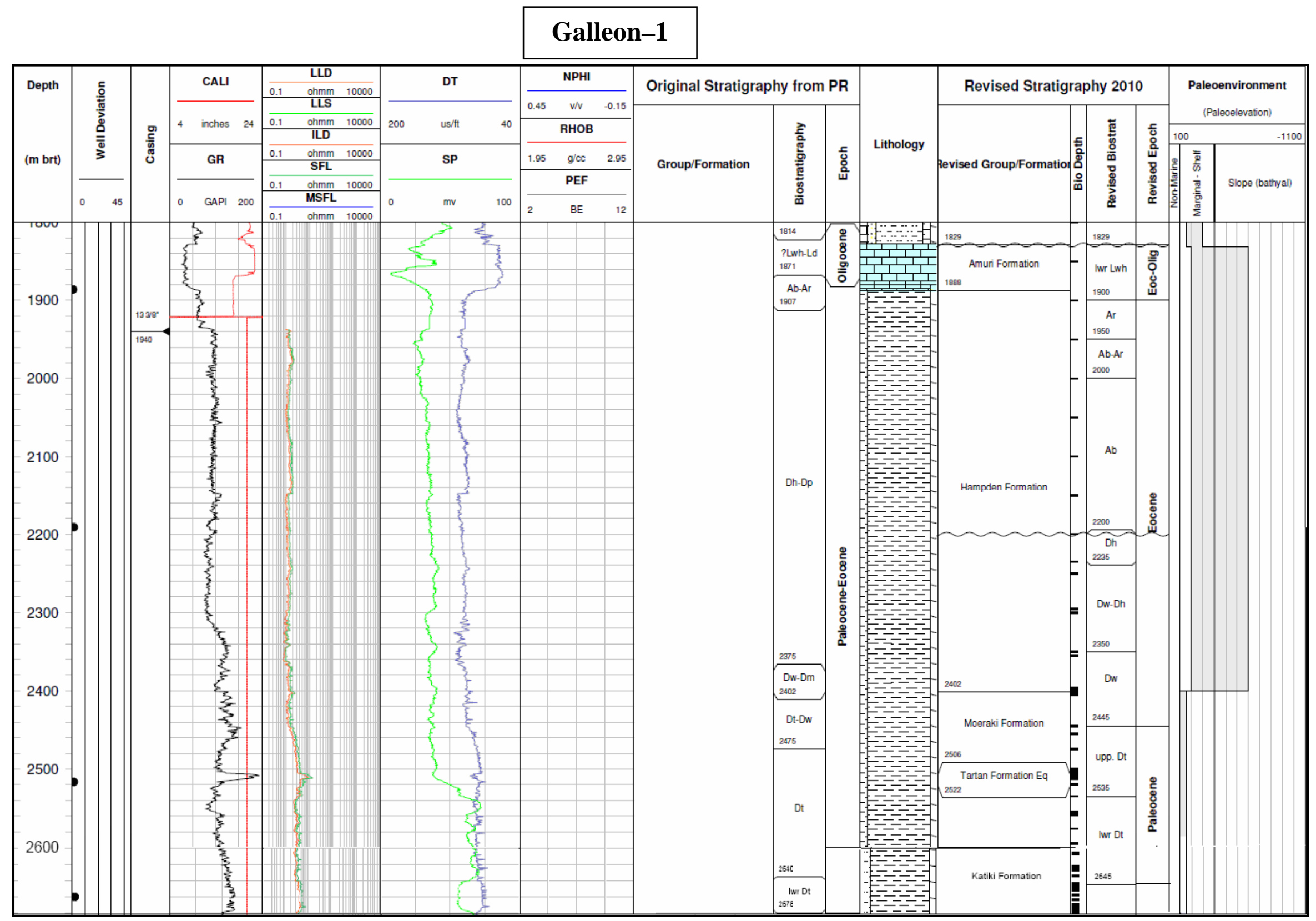




\section{ENDEAVOUR-1}

Country: New Zealand

Location: Canterbury

Latitude: $45^{\circ} 14^{\prime} 18.3^{\prime \prime} \mathrm{S} \quad$ Longitude: $171^{\circ} 07^{\prime} 30.9^{\prime \prime} \mathrm{E}$

New Zealand Map Grid Y: 5550645.9 m NX: 2362744.0 m E

Spud Date: $24 / 10 / 1970$

Directional Data: Near vertical well

Operator: Shell, BP \& Todd Oil Services Ltd

Petroleum Report: 303

Scale: $1: 5,000$
Total Depth: $2741.07 \mathrm{~m}$ brt

Ground Level Elevation: -38.71 m bmsl

Rotary Table Elevation: $34.44 \mathrm{~m}$ ams

Status: Plugged and abandoned

Hydrocarbon Shows: None

Edited by: Sanjay Samuel 


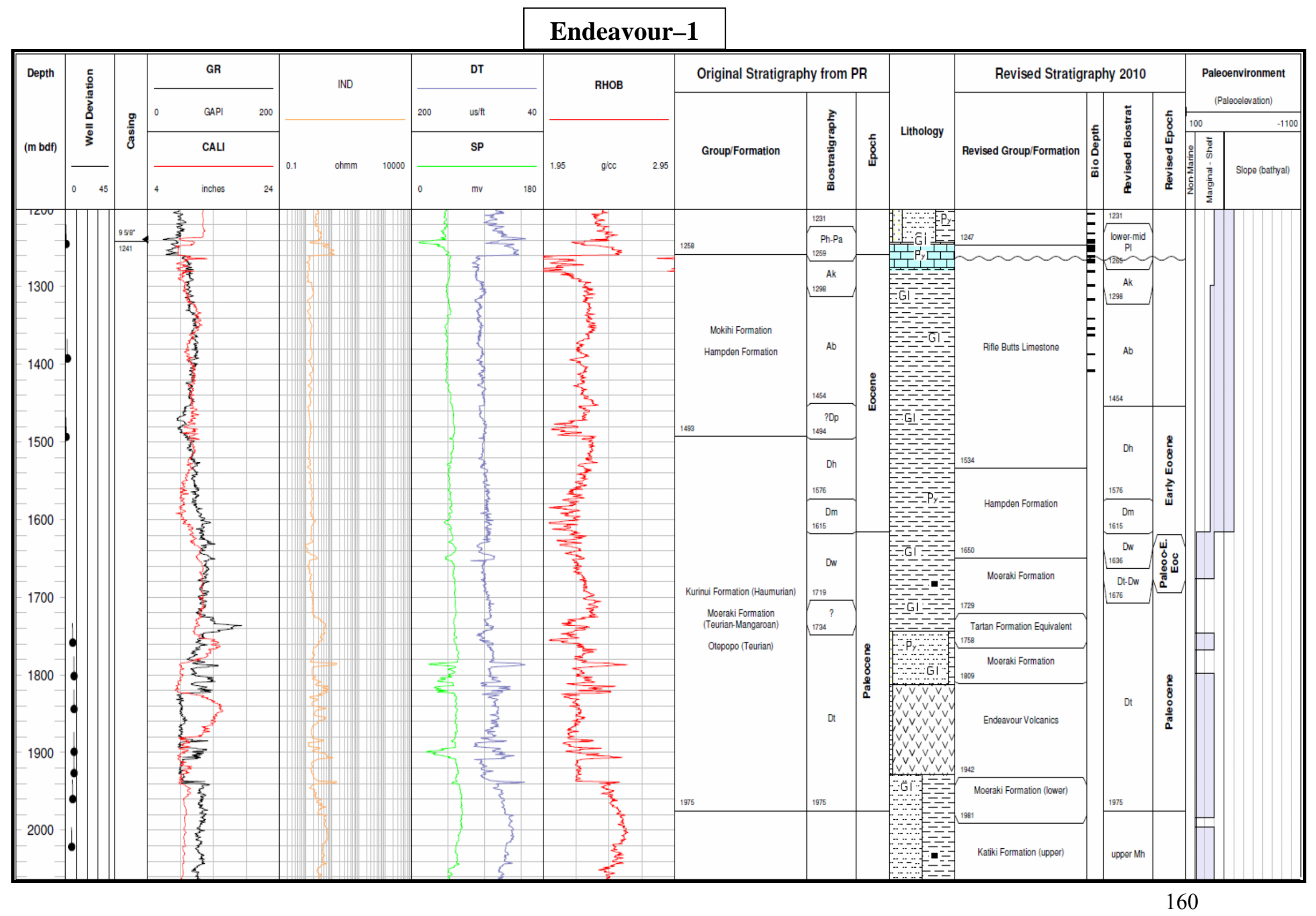




\section{CLIPPER-1}

Country: New Zealand

Basin: Canterbury

Latitude: -44.9708

Longitude: 171.8964

New Zealand Map Grid: 2422 911.71m E; 5581 463.41m N

Spud Date: 27/03/84

Directional Data: Near vertical well

Operator: Shell, BP \& Todd Oil Sevices Limited

Petroleum Report: 1036

Scale: $1: 5,000$
Total Depth: $4742 \mathrm{~m}$ brt

Ground Level Elevation: $-177 \mathrm{~m}$ bms

Rotary Table Elevation: $26 \mathrm{~m}$ amsl

Status: Plugged and abandoned

Hydrocarbon Shows: Gas/condensate

Edited by: Saniay Samuel 


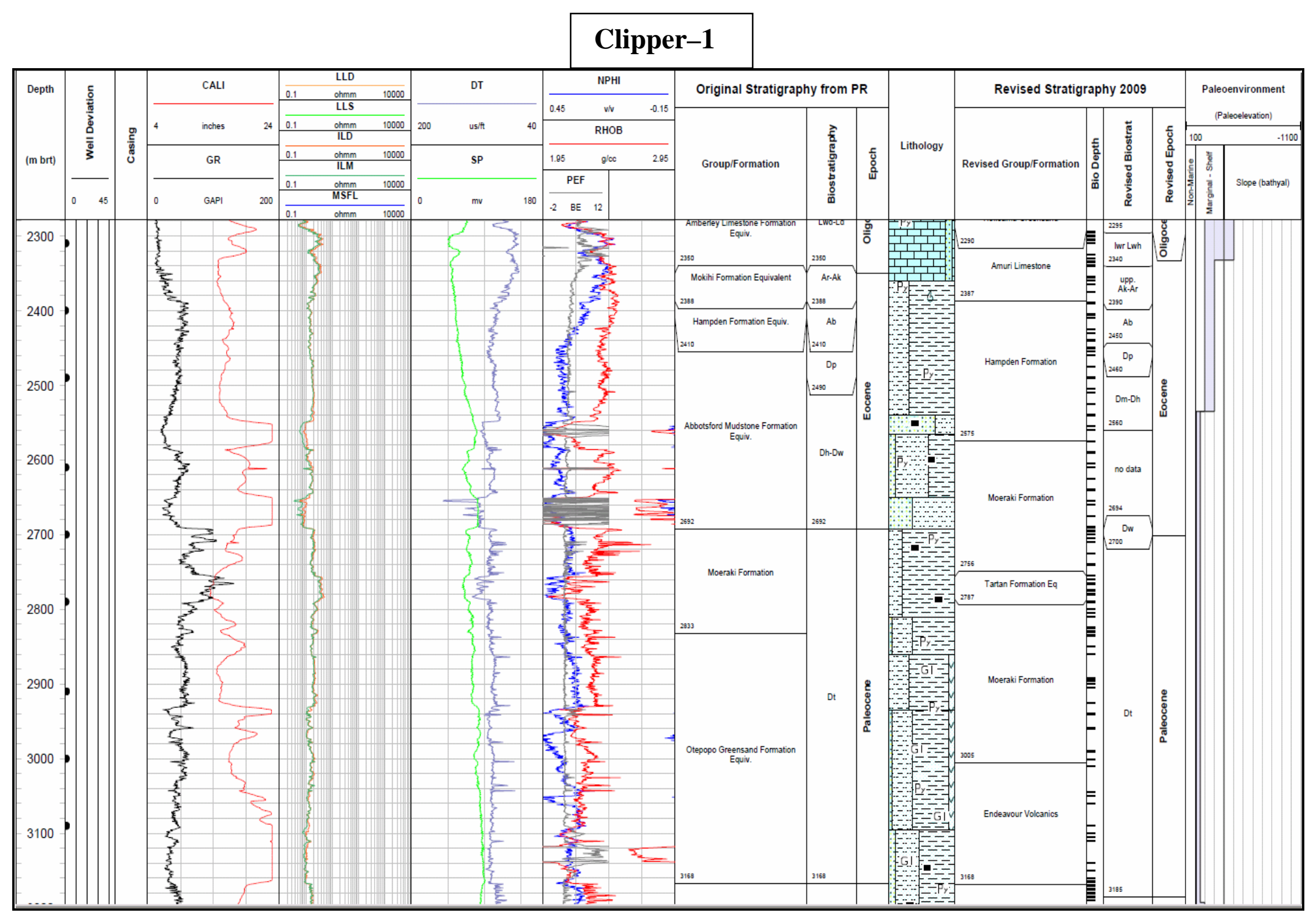




\section{RESOLUTION-1}

Country: New Zealand

Location: Canterbury

Latitude: $44^{\circ} 11^{\prime} 16.20^{\prime \prime} \mathrm{S}$ Longitude: $172^{\circ} 38^{\prime} 09.69 " \mathrm{E}$

New Zealand Map Grid Y: 5668963.8 m NX: 2480911.9 m E

Spud Date: 09/07/1975

Directional Data: Near vertical well

Operator: BP Shell Todd (Canterbury) Services Ltd

Petroleum Report: 648

Scale: $1: 5,000$
Total Depth: $1963 \mathrm{~m}$ brt

Ground Level Elevation: -64 m bmsl

Rotary Table Elevation: $10.0 \mathrm{~m}$ amsl

Status: Dry and abandoned

Hydrocarbon Shows: No shows

Edited by: Sanjay Samuel 


\section{Resolution-1}

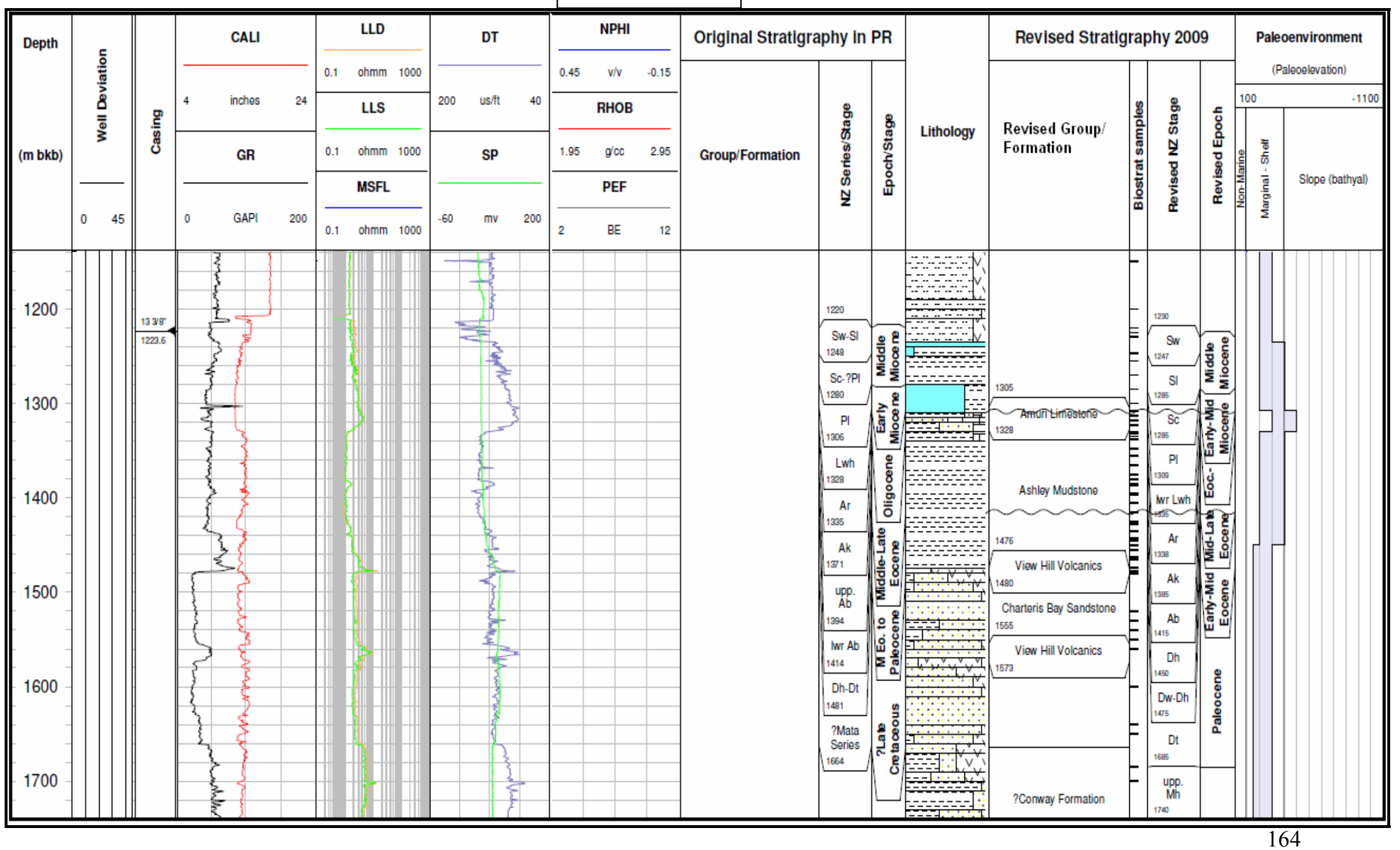

